UNIVERSIDADE DE SÃO PAULO

ESCOLA POLITÉCNICA DA UNIVERSIDADE DE SÃO PAULO

SARAH CRISTINA CARDOSO NUNES

Apoio ao processo de licitação e projetos em BIM para infraestrutura metroviária a partir de uma biblioteca de metacomponentes

São Paulo

2021 (Edição Original)

2021 (Versão Corrigida) 

SARAH CRISTINA CARDOSO NUNES

\title{
Apoio ao processo de licitação e projetos em BIM para infraestrutura metroviária a partir de uma biblioteca de metacomponentes
}

\author{
Versão Corrigida
}

Dissertação apresentada à Escola Politécnica da Universidade de São Paulo para obtenção do título de Mestre em Ciências.

Área de concentração: Inovação na Construção Civil

Orientador: Sérgio Leal Ferreira

\author{
São Paulo \\ 2021 (Edição Original) \\ 2021 (Versão Corrigida)
}


Autorizo a reprodução e divulgação total ou parcial deste trabalho, por qualquer meio convencional ou eletrônico, para fins de estudo e pesquisa, desde que citada a fonte.

Este exemplar foi revisado e corrigido em relação à versão original, sob responsabilidade única do autor e com a anuência de seu orientador.

São Paulo, 22 de Setembro de 2021.

Assinatura do autor:

Assinatura do orientador:

Catalogação-na-publicação

Nunes, Sarah Cristina Cardoso

Apoio ao processo de licitação e projetos em BIM para infraestrutura metroviária a partir de uma biblioteca de metacomponentes / S. C. C. Nunes versão corr. -- São Paulo, 2021

$243 \mathrm{p}$.

Dissertação (Mestrado) - Escola Politécnica da Universidade de São Paulo. Departamento de Engenharia de Construção Civil.

1. BIM 2. Metrô 3. Projetos de obras públicas 4. Inovação tecnológica I. Universidade de São Paulo. Escola Politécnica. Departamento de Engenharia de Construção Civil II.t. 
Nome: NUNES, Sarah Cristina Cardoso.

Título: Apoio ao processo de licitação e projetos em BIM para infraestrutura metroviária a partir de uma biblioteca de metacomponentes.

Dissertação apresentada à Escola Politécnica da Universidade de São Paulo para obtenção do título de Mestre em Ciências.

Aprovado em:

\section{Banca Examinadora}

Prof.(a) Dr.(a)

Instituição:

Julgamento:

Prof.(a) Dr.(a)

Instituição:

Julgamento:

Prof.(a) Dr.(a)

Instituição:

Julgamento: 



\section{RESUMO}

NUNES, S. C. C. Apoio ao processo de licitação e projetos em BIM para infraestrutura metroviária a partir de uma biblioteca de metacomponentes. 2021. Dissertação (Mestrado profissional em Inovação na Construção Civil) - Escola Politécnica, Universidade de São Paulo, São Paulo, 2021.

A motivação da pesquisa surge da experiência profissional com projetos de estações metroviárias e, com a constatação da dificuldade do poder público na realização das obras dentro dos padrões desejados de qualidade, custo e prazo. No processo tradicional de contratação das obras públicas, a baixa qualidade dos projetos licitatórios, as falhas de planejamento e as irregularidades na gestão dos recursos são apontados por diversos autores como os principais problemas para a qualidade das obras. Diante desse contexto, as iniciativas para adoção da metodologia BIM pelo setor público buscam aumentar a qualidade dos projetos e orçamentos, resultando em maior transparência e controle no fluxo das informações. A pesquisa tem como foco os projetos e as contratações da Companhia do Metropolitano de São Paulo - Metrô/SP, no qual é observado um elevado número de soluções, elementos e materiais padronizados, fato que pode aproximar este tipo de construção aos processos de fabricação. O principal objetivo do estudo é discutir e propor soluções para a introdução de uma biblioteca de metacomponentes BIM no contexto de elaboração e contratações das obras públicas metroviárias. A fim de encontrar subsídios para o desenvolvimento da proposta, na primeira parte do trabalho é realizado um levantamento do processo tradicional de licitação e desenvolvimento dos projetos na Companhia, estudando também referências tecnológicas de apoio ao processo de projeto e bibliotecas BIM. A segunda parte da pesquisa apresenta o desenvolvimento do artefato, que é constituído de um acervo composto por projetos padrão modelados e paramétricos, com seus elementos relacionados a tabelas de referência. A partir do desenvolvimento de um item da biblioteca foram discutidas características de modelagem, a inserção das regras do Metrô/SP no modelo e a parametrização do metacomponente. Desse modo, o estudo fornece elementos que abrem caminho para tornar a indústria da construção civil mais apta ao uso de ferramentas modernas e precisas para auxiliar o desenvolvimento e controle das obras metroviárias.

Palavras-chave: BIM, metrô, licitações, obras públicas. 



\begin{abstract}
NUNES, S. C. C. Support for the bidding process and BIM projects for subway infrastructure through a multicomponent library. 2021. Dissertação (Mestrado profissional em Inovação na Construção Civil) - Escola Politécnica, Universidade de São Paulo, São Paulo, 2021.

The motivation of this study arose from the experience of the author with the development of subway station projects and, on the observation that public entities have difficulties to execute works within the desired standards of quality, cost and time. In the traditional process of contracting public works, the low quality of bidding projects, planning failures and irregularities in the management are pointed out as main problems for the quality of the works. In light of this context, some public initiatives of BIM adoption for public construction aim to increase the quality of projects and optimizing budgets, resulting in greater transparency and information flow control. The present work focuses on the contracting process of Metrô (the São Paulo state subway company), in which a high number of standardized solutions, elements and materials are observed, a fact that can bring this type of construction to the manufacturing processes. The aim of this paper is to discuss and propose solutions for the introduction of BIM multicomponent library in the Brazilian context of contracting public works. In order to find subsidies for the development of the proposal, in the first part of the research the traditional bidding process and development of the Company's projects is studied, as well as references of Algorithm Aided Design and BIM libraries. The second part of the work presents the development of the artifact, which consists of a collection composed of standard modeled and parametric projects, with its elements related to reference tables. From the development of a library item, modeling characteristics, the insertion of the rules of Metrô/SP in the model and the parameterization of the multicomponent were discussed. Therefore, the study will provide elements that pave the way for making the construction industry more modern and efficient.
\end{abstract}

Keywords: BIM, subway, bidding process, public works. 



\section{LISTA DE FIGURAS}

Figura 1 - Índice de produtividade da indústria (Valor agregado por hora trabalhada)

Figura 2 - Tecnologias que podem melhorar a produtividade da indústria de infraestrutura e desenvolvimento urbano 29

Figura 3 - Rede de metrô da cidade de São Paulo: consolidada (2017) e projetada (2030)

Figura 4 - Conscientização do problema 34

Figura 5 - Esquema de execução da DSR 35

Figura 6 - Conjunto normativo aplicado à licitação e contratação de obra pública...43

Figura 7 - Procedimentos para viabilização de obras públicas .44

Figura 8 - Etapas da fase externa da licitação 46

Figura 9 - Padronização internacional BIM .57

Figura 10 - Algoritmo simples e múltiplo. 59

Figura 11- Processo de projeto definido por Slunecko 60

Figura 12 - Bibliotecas de componentes BIM analisadas 63

Figura 13 - Página de busca por produtos, com detalhe para os filtros disponíveis. 64

Figura 14 - Página de busca por produtos da BIM Tool. 66

Figura 15 - Página de busca por produtos, com detalhe das categorias 68

Figura 16 - Aquisição de objetos BIM 69

Figura 17 - Tabela de quantitativos de algumas quadras da família da FDE .72

Figura 18 - Visualização 3D de mobiliário de sala modelados pela FDE 73

Figura 19 - Impressão 3D de uma peça de um objeto da FDE, a partir do seu protótipo

Figura 20 - Últimos catálogos técnicos da FDE atualizados .74 
Figura 21 - Fases do empreendimento no Metrô/SP .80

Figura 22 - Processo de concepção e contratação da estação Ponte Grande .........84

Figura 23 - Exemplo de estudo do traçado: planta e perfil ...................................8

Figura 24 - Exemplo de estudo preliminar: implantação e corte esquemático..........89

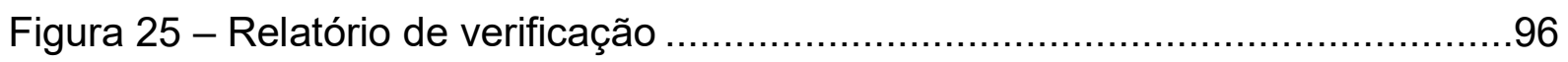

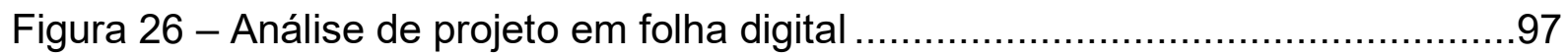

Figura 27 - Fluxo de projetos no processo BIM..............................................100

Figura 28 - Análise e comentários do modelo em IFC .....................................102

Figura 29 - Registro de uma reunião sobre o projeto de arquitetura .....................102

Figura 30 - Comparativo entre o processo de análise tradicional e BIM ...............104

Figura 31 - Exemplo de componentes padronizados para estações na França .....108

Figura 32 - Projeto padrão (PP) EK05: lixeira ............................................109

Figura 33 - Estação AACD, linha 5-Lilás: Lajes intermediárias em execução ........112

Figura 34 - Procedimentos para execução de trincheiras ou VCA ……………....113

Figura 35 - Seção típica do túnel em NATM ..................................................114

Figura 36 - Funcionamento do shield........................................................115

Figura 37 - Programa de estações de metrô..................................................117

Figura 38 - Grupos de estações ………………...................................119

Figura 39 - Exemplos de tipologias e métodos construtivos ………..................121

Figura 40 - Composição dos metacomponentes .............................................126

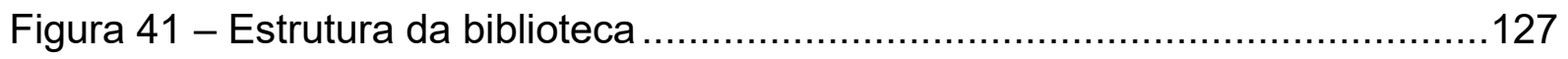

Figura 42 - Repetição do padrão construtivo: projetos Linha 2-Verde...................129

Figura 43 - Desenvolvimento de projeto: metacomponente x projeto específico....130

Figura 44 - Metacomponentes do Grupo A …...............................................131 
Figura 45 - Metacomponentes do Grupo B.

Figura 46 - Estrutura da biblioteca: exemplo de metacomponenes por grupo ....... 134

Figura 47 - Estrutura do arquivo - Definição de pisos .................................. 136

Figura 48 - Estrutura do arquivo: Inserção do Mezanino intermediário ................. 137

Figura 49 - Composição de uma parede de concreto ................................... 138

Figura 50 - Modelagem das paredes - Altura......................................... 139

Figura 51 - Erros de representação: quebra do vínculo entre as paredes ............. 140

Figura 52 - Modelo separados: arquitetura e estrutura .............................. 141

Figura 53 - Recurso para visualização e separação dos itens de estrutura ........... 142

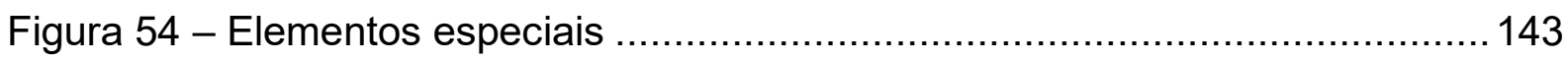

Figura 55 - Posição dos caixilhos entre pavimentos ................................. 144

Figura 56 - Posição dos caixilhos entre pavimentos: solução ........................... 145

Figura 57 - Classificação e características das escadas fixas .......................... 147

Figura 58 - Classificação e características dos equipamentos ........................ 147

Figura 59 - Classificação e características dos equipamentos .......................... 148

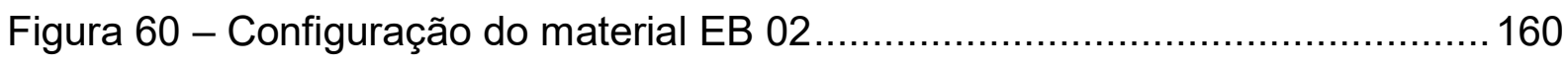

Figura 61 - Classificação dos componentes: exemplo piso tátil ......................... 161

Figura 62 - Plataforma: exposição das regras de alerta e norma ....................... 162

Figura 63 - Principais parâmetros do metacomponente .............................. 164

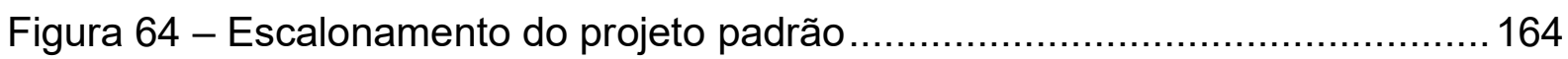

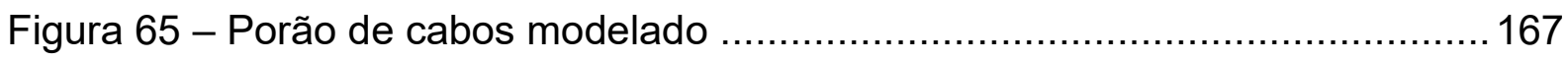

Figura 66 - Parâmetros do Porão de Cabos .......................................... 171

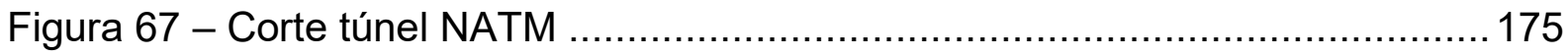

Figura 68 - Planta exaustão e insuflação da plataforma ................................ 175 


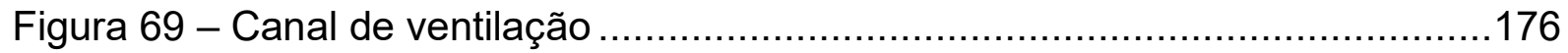

Figura 70 - Parâmetros do Canal de ventilação Inferior .......................................178

Figura 71 - Regra: diferença de altura entre o T.B. e a plataforma .......................180

Figura 72 - Corte Túnel NATM: Dimensões variáveis e fixas ...............................183

Figura 73 - Imagem do metacomponente - Túnel NATM ..................................184

Figura 74 - Poço central: parâmetros de dimensionamento .................................185

Figura 75 - Mezanino Intermediário: parâmetros de dimensionamento..................194

Figura 76 - Painéis de revestimento do poço central .........................................196

Figura 77 - Materiais de construção: itens de orçamento...................................199

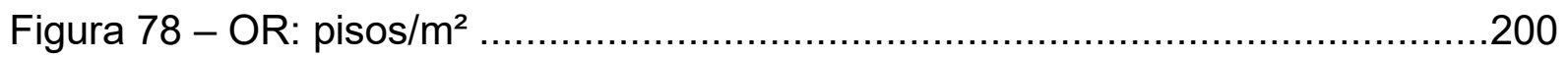

Figura 79 - Propriedades e vínculos para orçamentação......................................200

Figura 80 - Acesso padrão, Linha 1 - Bilbao, Espanha ....................................208

Figura 81 - Estações em túnel projetadas por Norman Foster.............................208

Figura 82 - Exemplo de processo de projeto com a biblioteca proposta ...............222

\section{LISTA DE TABELAS}

Tabela 1 - Taxa Média de Crescimento da Produtividade (\% ao ano) .....................28

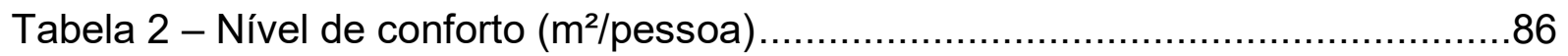

Tabela 3 - Número de comentários da estação Ponte Grande (projeto em BIM) ...103

Tabela 4 - Número de comentários da estação Guilherme Giorgi (processo tradicional).

Tabela 5 - Tabela de portas do pavimento Porão de Cabos ……….....................144

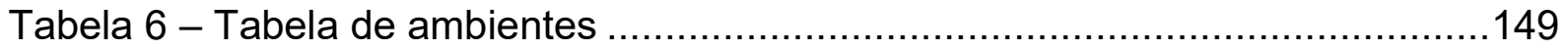




\section{LISTA DE QUADROS}

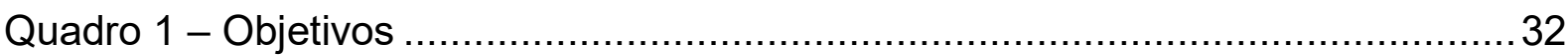

Quadro 2- Elementos exigidos na elaboração do edital pela Lei n 8.666/1993 .....45

Quadro 3 - Regimes de contratações da CMSP ..........................................48

Quadro 4 - Conjunto de padrões para interoperabilidade baseada em objetos .......56

Quadro 5 - Tipologia de projeto mediado por computadores e algoritmos.............61

Quadro 6 - Metrô/SP - Implantação dos empreendimentos: Comparativo entre os

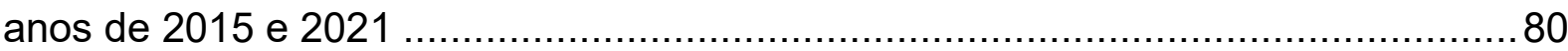

Quadro 7 - Atividades e disciplinas do Projeto Básico................................. 92

Quadro 8 - Tipos de Metrô .................................................................. 110

Quadro 9 - Premissas para padronização da rede da RMSP ..............................119

Quadro 10 - Classificação das regras da CMSP ............................................ 150

Quadro 11 - Regras da CMSP utilizadas no desenvolvimento do metacomponente 152

Quadro 12 - Quadro geral de aplicação de materiais ................................... 166

Quadro 13 - Porão de cabos: itens fixos................................................. 168

Quadro 14 - Porão de cabos: itens variáveis ............................................... 172

Quadro 15 - Canal de ventilação inferior: itens fixos .................................. 173

Quadro 16 - Canal de ventilação inferior: itens variáveis ............................... 178

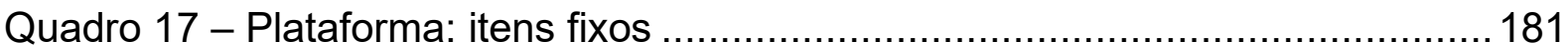

Quadro 18 - Plataforma: itens variáveis............................................... 185

Quadro 19 - Mezanino Inferior: itens fixos ................................................ 188

Quadro 20 - Mezanino Inferior: itens variáveis ............................................ 191

Quadro 21 - Mezanino Intermediário: itens fixos .......................................... 193 
Quadro 22 - Mezanino Intermediário: itens variáveis 194

Quadro 23 - Temas das tabelas de orçamento...... 199

\section{LISTA DE GRÁFICOS}

Gráfico 1 - Estações de metrô: tipo e ano de inauguração 111

Gráfico 2 - Tipo de método construtivo por empreendimento 116

\section{LISTA DE DIAGRAMAS}

Diagrama 1 - Dados e parâmetros do Porão de cabos 170

Diagrama 2 - Dados e parâmetros do Canal de Ventilação Inferior 177

Diagrama 3 - Dados e parâmetros da Plataforma 182

Diagrama 4 - Dados e parâmetros do Mezanino Inferior 190

Diagrama 5 - Dados e parâmetros do Mezanino Intermediário 197 


\section{LISTA DE SIGLAS}

AAD Algorithm Aided Design

ABNT Associação Brasileira de Normas Técnicas

AEC Arquitetura, Engenharia e Construção

BCF BIM Collaboration Format

BIM Building Information Modelling

CAD Computer Aided Design

CBIC Câmara Brasileira da Indústria da Construção

CPTM Companhia Paulista de Trens Metropolitanos

DSR Design Science Research

EUBIM EU BIM task group

FDE Fundação para o Desenvolvimento da Educação

FGV Fundação Getúlio Vargas

FIESP Federação das Indústrias do Estado de São Paulo

GIS Sistema de informação geográfica

IFC Industry Foundation Classes

IP Instrução de projeto

ISO Organização Internacional de Padronização

LDO Lei de Diretrizes Orçamentárias

LOA Lei Orçamentária Anual

LOD Levels of Development

MDIC Ministério da Indústria, Comércio Exterior e Serviços

MEP Mechanical, Eletrical, Pumbling e Piping 
NATM New Austrain Tunnelling Method

NBR Norma Técnica brasileira

NBS National BIM Library

ND Níveis de Desenvolvimento

PIB Produto Interno Bruto

PITU Plano Integrado de Transportes Urbanos

PP Projeto padrão

PPA Plano Plurianual

PPP Parceria-público-privada

PTF Produtividade Total dos Fatores

RDC Regime Diferenciado de Contratações Públicas

RMSP Região Metropolitana de São Paulo

SEIL Secretaria de Infraestrutura e Logística do Paraná

SINAPI Sistema Nacional de Pesquisa de Custos e Índices da Construção Civil

STM Secretaria de Transportes Metropolitanos do Estado de São Paulo

TBM Tunnel Boring Machines

TCU Tribunal de Contas da União

VCA Vala a Céu Aberto 


1 | INTRODUÇÃO

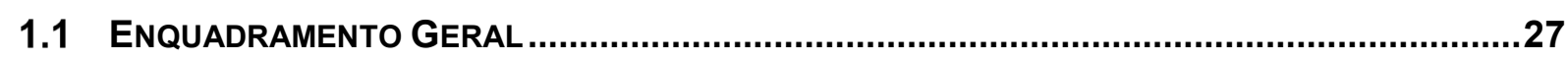

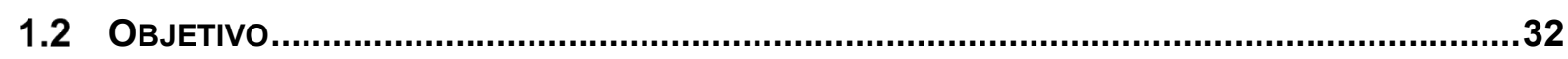

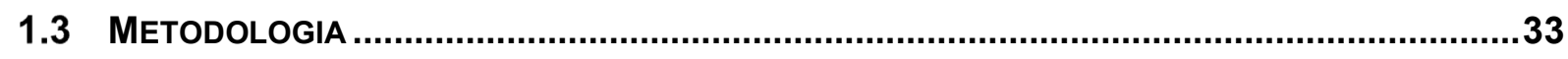

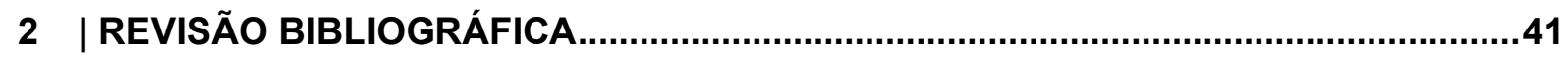

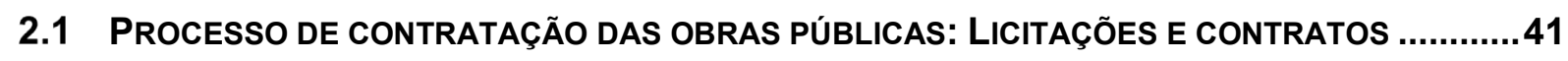

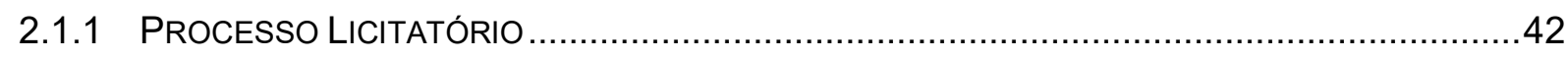

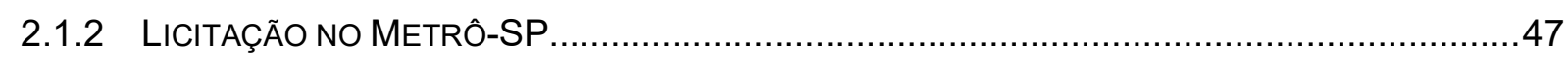

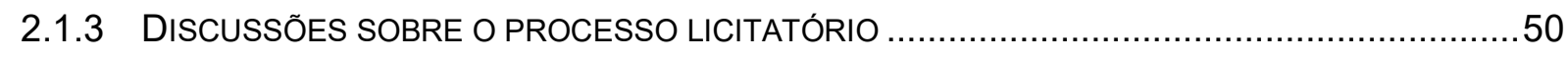

2.2 TECNOLOGIAS DE APOIO AO PROCESSO DE PROJETO ...................................................53

2.2.1 MODELAGEM PARAMÉTRICA E A METODOLOGIA BIM ...................................................53

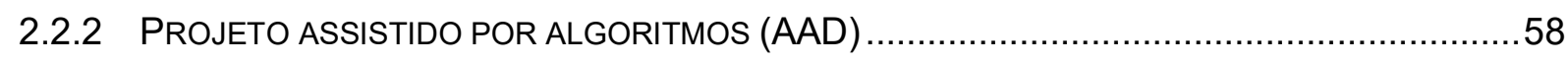

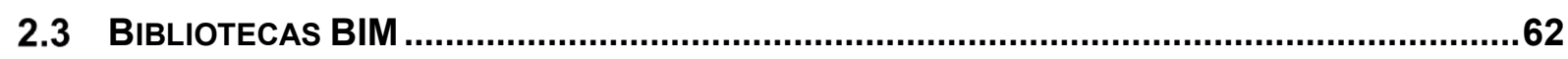

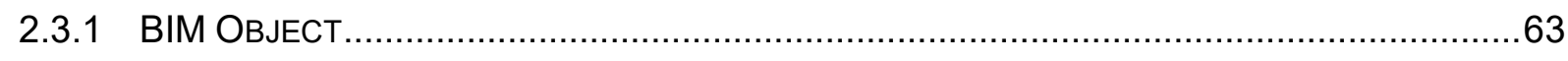

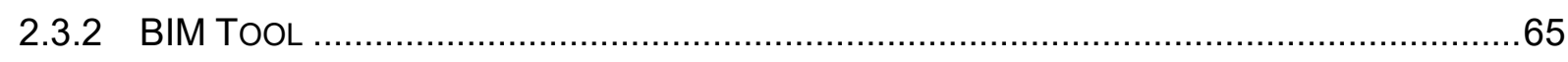

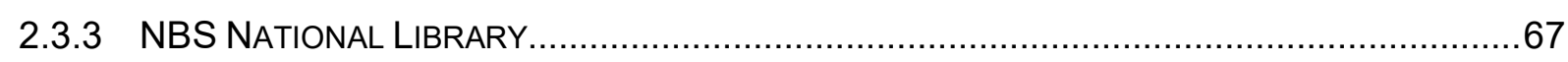

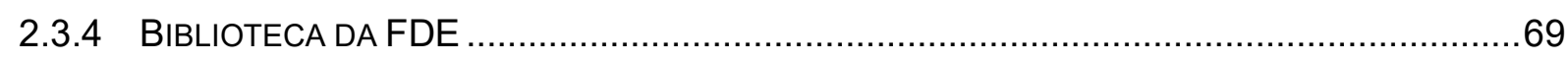

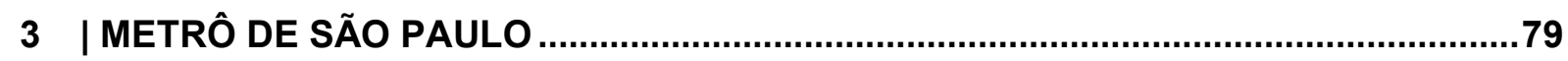

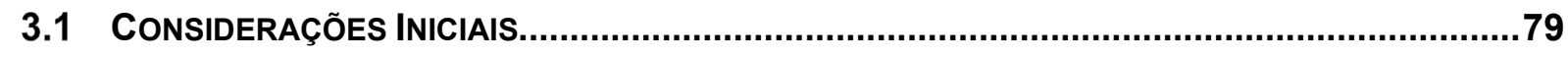

3.2 PROCESSO de PROJeto No Metrô de SÃo PAULO.........................................................84

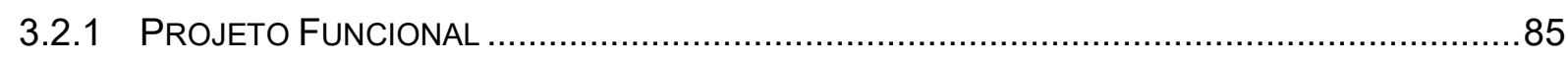

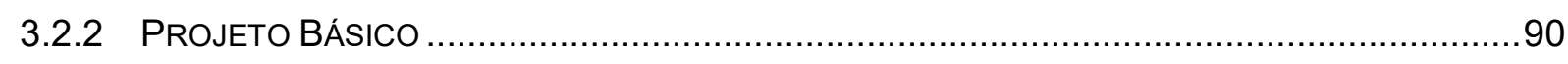


3.2.3 DESENVOLVIMENTO E ANÁLISE DO PROJETO BÁSICO.............................................. 95

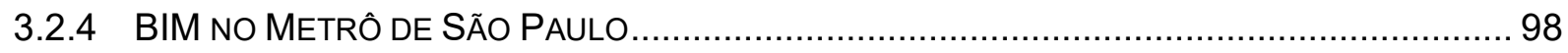

3.3 INDUSTRIALIZAÇÃO E PADRONIZAÇÃO DE ESTAÇõES DE METRÔ...................................... 106

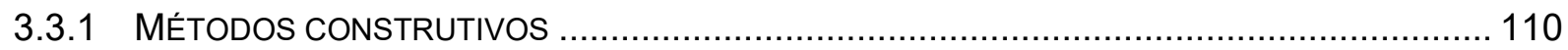

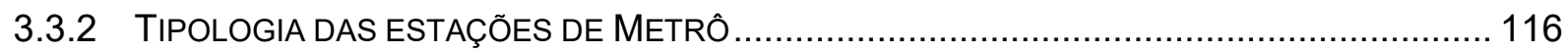

4 | BIBLIOTECA DE METACOMPONENTES BIM PARA O METRÔ/SP ........................ 125

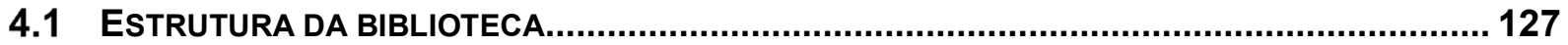

4.1.1 GRUPO A - ESTAÇÃO COM PLATAFORMAS EM TÚNEL .............................................. 130

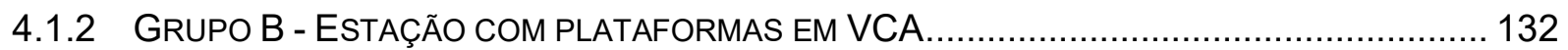

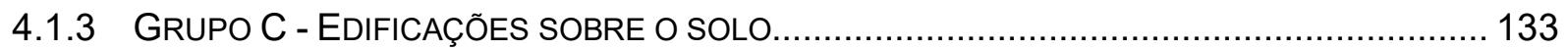

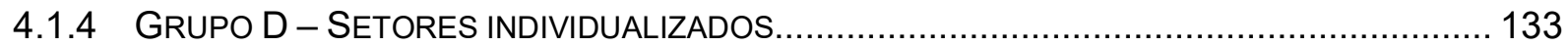

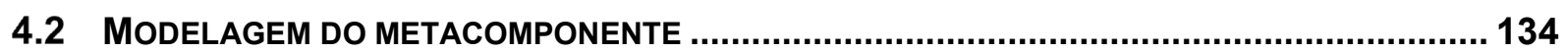

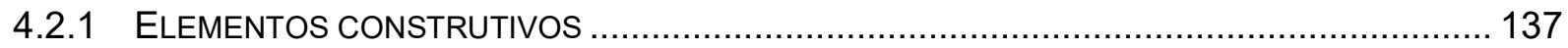

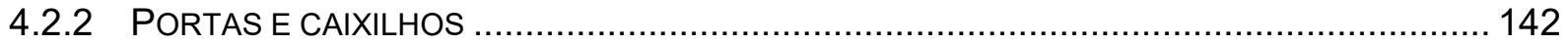

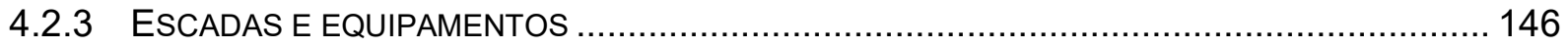

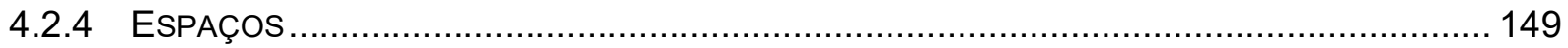

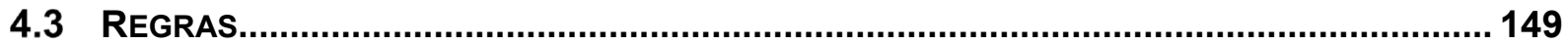

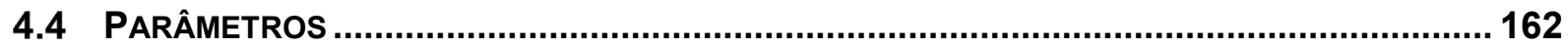

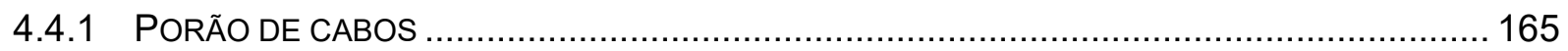

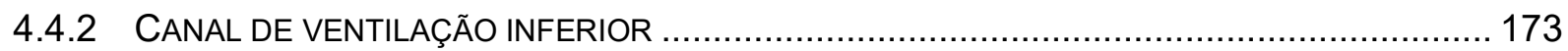

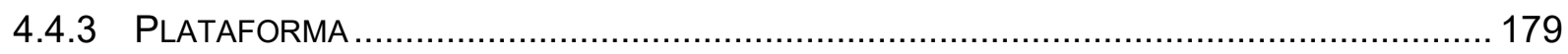

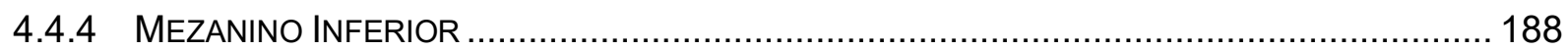

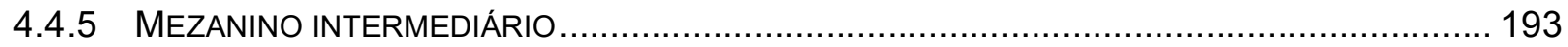

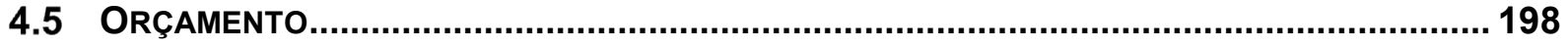

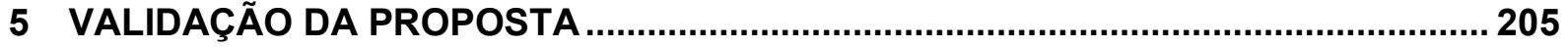


5.1 EntReVISTA “A”: PROJETISTA do MetRô/SP

5.2 ENTREVISTA "B": Gestora do Metrô/SP

5.3 EnTREVISTA “C”: Projetista EXTERno

6 | CONSIDERAÇÕES FINAIS 


\section{1}
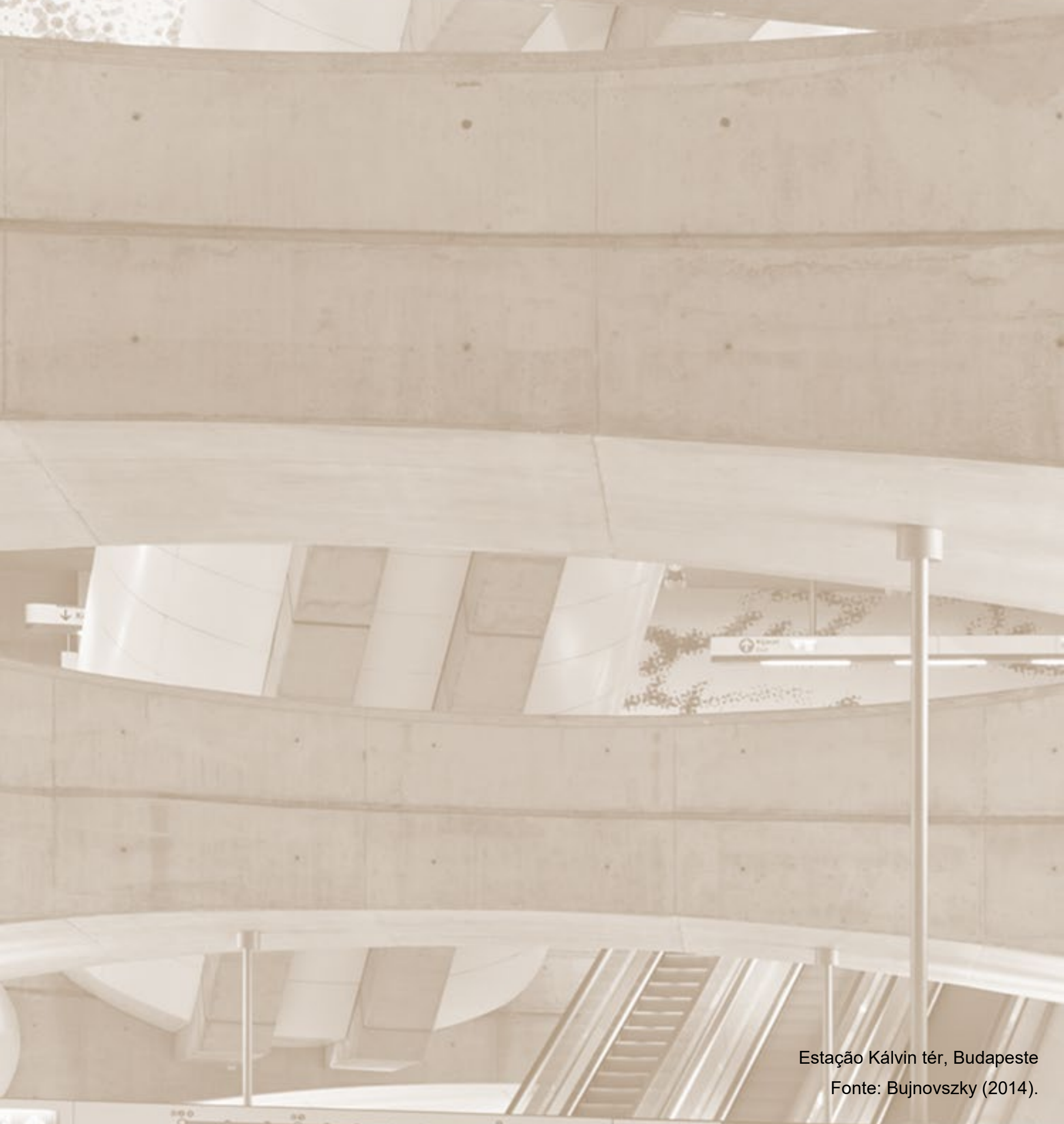

Fonte: Bujnovszky (2014). 
CAPÍTULO 1 | INTRODUÇÃO 



\section{1 | INTRODUÇÃO}

\subsection{ENQUADRAMENTO GERAL}

Nas últimas décadas, a indústria da construção não conseguiu acompanhar o desenvolvimento tecnológico e os ganhos de produtividade gerados por outros segmentos industriais como, por exemplo, a indústria automobilística e a agroindústria. Fato que impacta no crescimento das economias nacionais, na qualidade de vida da população e nas questões ambientais.

Segundo a revista The Economist (2017), a construção civil possui os menores índices de produtividade em comparação a outras indústrias. Nos últimos 20 anos, a Alemanha e o Japão, modelos em eficiência industrial, praticamente não apresentaram crescimento na produtividade da construção, e nos Estados Unidos o número caiu pela metade desde o final dos anos 60 , conforme ilustrado na Figura 1.

Figura 1 - Índice de produtividade da indústria (Valor agregado por hora trabalhada)

\section{Unlearning by doing}

United States, gross value-added*

Per hour worked, $1947=100$

Agriculture

Manufacturing

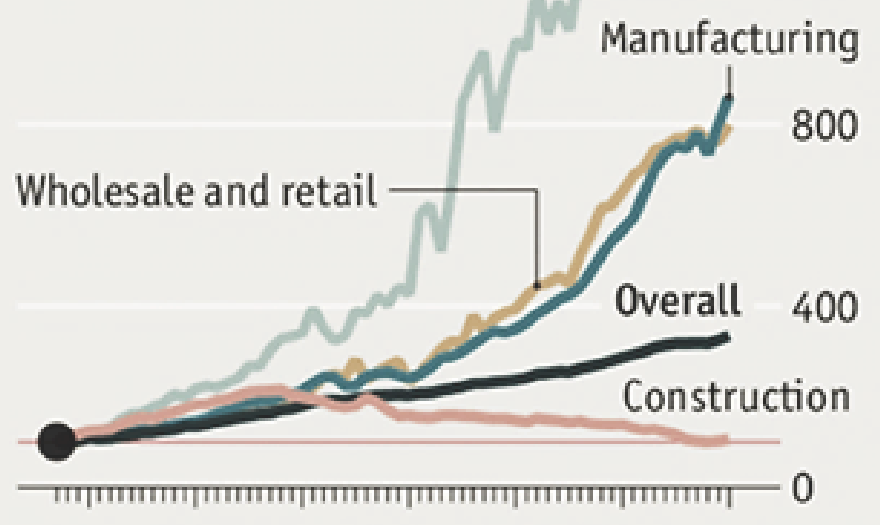

$\begin{array}{lllllll}1947 & 60 & 70 & 80 & 90 & 2000 & 10\end{array}$

Source: McKinsey Global Institute *At constant prices

Fonte: The Economist (2017). 
No Brasil, seguindo a tendência mundial, um estudo da CBIC - Câmara Brasileira da Indústria da Construção em parceria com a FGV - Fundação Getúlio Vargas entre o período de 2007 a 2012, revela que a Produtividade Total dos Fatores (PTF) das empresas de construção civil apresentou declínio médio de 0,4\% ao ano (CBIC/FGV, 2014). Os dados são apresentados na Tabela 1.

Tabela 1 - Taxa Média de Crescimento da Produtividade (\% ao ano)

\begin{tabular}{cccc}
\hline Período & $\begin{array}{c}\text { Produtividade do } \\
\text { Trabalho }\end{array}$ & $\begin{array}{c}\text { Produtividade do } \\
\text { Capital }\end{array}$ & $\begin{array}{c}\text { Produtividade Total } \\
\text { dos Fatores (PTF) }\end{array}$ \\
\hline $\mathbf{2 0 0 7 / 2 0 1 2}$ & $-0,2 \%$ & $-0,5 \%$ & $-0,4 \%$ \\
\hline $\mathbf{2 0 0 7 / 2 0 1 0}$ & $-1,2 \%$ & $1,4 \%$ & $0,0 \%$ \\
\hline $\mathbf{2 0 1 0 / 2 0 1 2}$ & $1,3 \%$ & $-3,3 \%$ & $-1,0 \%$ \\
\hline
\end{tabular}

Fonte: CBIC/FGV (2014).

Além das questões de produtividade, no caso das obras públicas brasileiras é notória a dificuldade que a Administração tem de realizar as obras dentro dos padrões desejados de qualidade, custo e prazos (SANTOS, 2015). Os problemas na gestão dos recursos geralmente estão associados a corrupção, que resulta em perdas de aproximadamente 200 bilhões de reais ao ano, cerca de $3 \%$ do PIB nacional (PORTUGAL, 2017).

No processo tradicional de contratação das obras públicas, a baixa qualidade dos projetos licitatórios, as falhas de planejamento, com cronogramas e orçamentos imprecisos e as irregularidades na gestão dos recursos destinados à essas obras são apontados por diversos autores como os principais problemas para a qualidade das obras.

O baixo desempenho do setor da construção civil, somado a carência de inovações tecnológicas e a falta de qualidade dos projetos públicos apontam para a necessidade de pesquisa, modernização e reestruturação da indústria da construção civil, em especial a área de equipamentos urbanos ${ }^{1}$.

\footnotetext{
1 A Norma Brasileira NBR 9284/86, define equipamento urbano como "todos os bens públicos e privados, de utilidade pública, destinados à prestação de serviços necessários ao funcionamento da cidade, implantados mediante autorização do poder público, em espaços públicos e privados." Esta norma classifica os equipamentos urbanos em categorias e subcategorias segundo sua função predominante. As dez categorias determinadas pela norma são: circulação e transporte, cultura e
} 
Conforme ilustrado na Figura 2, as tecnologias digitais, como impressão 3D, pré-fabricação, equipamentos de construção inteligente e dispositivos móveis, podem evitar desperdícios, além de aumentar a agilidade e a qualidade de projetos e obras. Apontado como principal fator da transformação digital no setor da construção civil, a plataforma BIM (Building Information Modelling) tem potencial para fornecer e manipular dados precisos e consistentes, necessários a tais inovações tecnológicas (WORLD ECONOMIC FORUM, 2018).

Figura 2 - Tecnologias que podem melhorar a produtividade da indústria de infraestrutura e desenvolvimento urbano

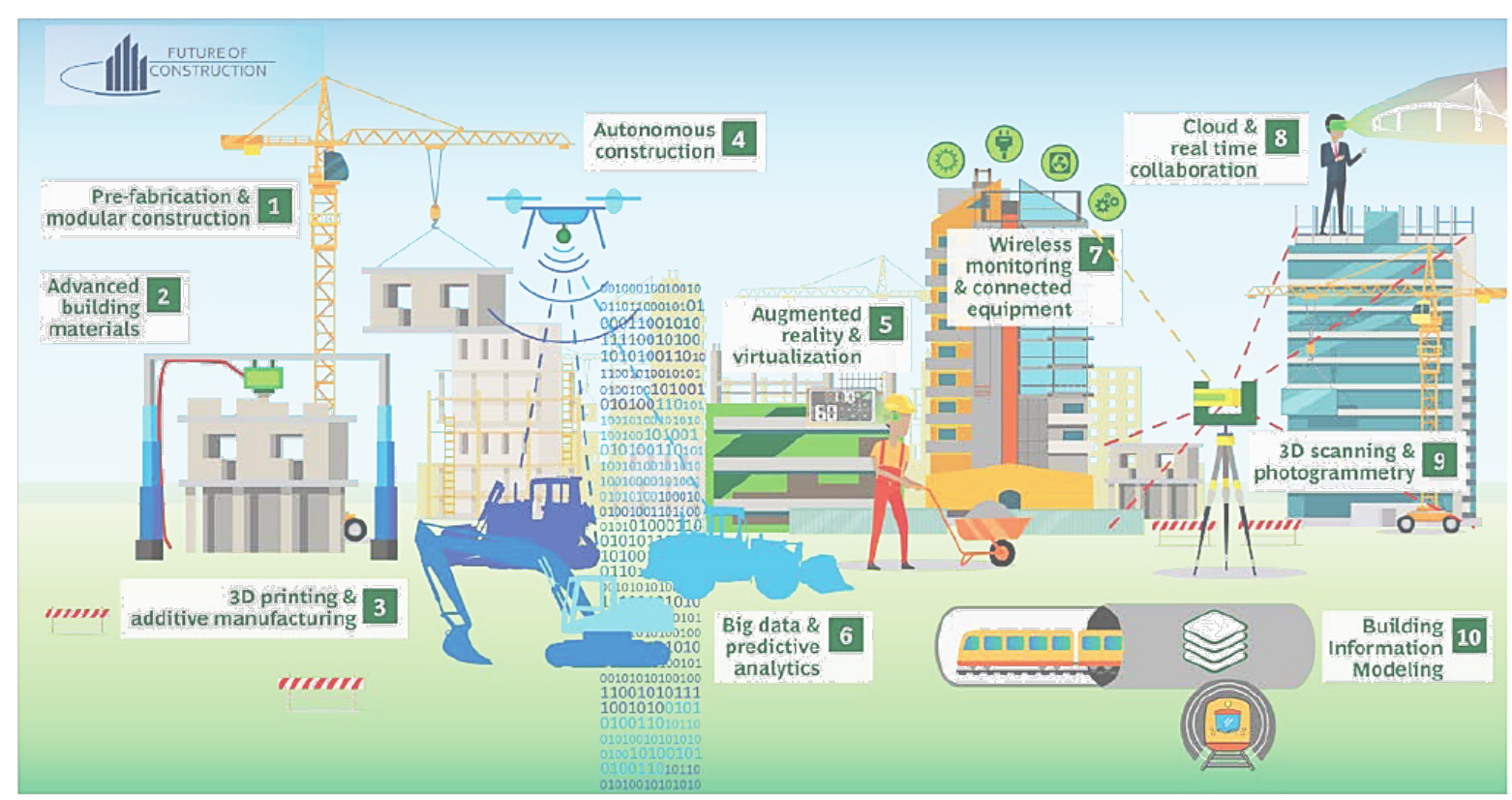

Fonte: World Economic Forum (2018).

Segundo o EU BIM task group (2017), um fator estratégico de viabilização da tecnologia é a sua adoção pelo setor público. A liderança, pelo governo e organizações públicas, da transição da indústria da construção para a era digital possibilitará uma abordagem transversal a todo setor da construção, com o desenvolvimento de definições e práticas harmônicas para o uso do BIM.

No Brasil, em 17 de maio de 2018, foi instituída através do decreto $\mathrm{N}^{\circ}$ 9.377, a Estratégia Nacional de Disseminação do BIM, com a finalidade de desenvolver medidas para regular, capacitar e difundir a tecnologia nacionalmente.

religião, esporte e lazer, infraestrutura, sistema de comunicação, sistema de energia, sistema de iluminação pública, sistema de saneamento, segurança pública e proteção, abastecimento, administração pública, assistência social, educação e saúde. (ABNT,1986) 
Para o setor público a implantação do BIM representa o controle e gerenciamento de um grande volume de dados, melhor entendimento de projetos, transparência nos orçamentos, com menor risco de oneração das obras, resultando em mais construções de equipamentos urbanos, com o mesmo ou menor investimento.

Os desafios para o setor público são inúmeros, no entanto, a pesquisa será direcionada a indústria de infraestrutura, em especial na área de mobilidade urbana, com o objetivo de oferecer um aprimoramento ao processo de contratação e desenvolvimento de projetos de edificações metroviárias.

A disponibilidade de equipamentos de circulação e transporte é a chave para equalizar a mobilidade urbana nas grandes cidades, como São Paulo. A Figura 3 representa esquematicamente a rede consolidada de metrô da cidade de São Paulo em 2017 e a rede projetada para 2030 pela Secretaria de Transportes Metropolitanos do Estado de São Paulo (STM).

Figura 3 - Rede de metrô da cidade de São Paulo: consolidada (2017) e projetada (2030) ${ }^{2}$

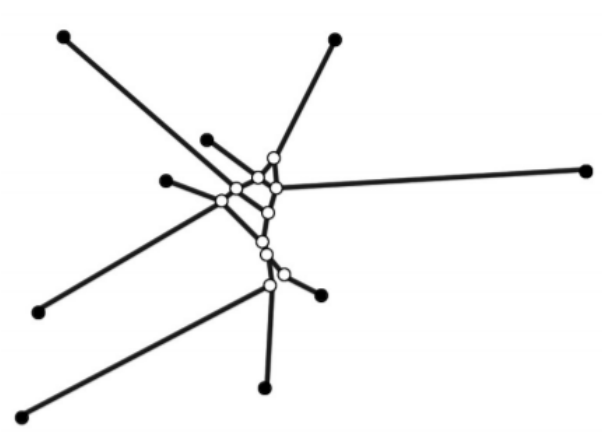

SĀo PAULO - 2017 (consolidada)

nós $=19$ (9 terminais +10 conexóes $)$ nos $=19(9$ terminais +10 conexóes)
links $=21$ (20 simples +1 múltiplo)

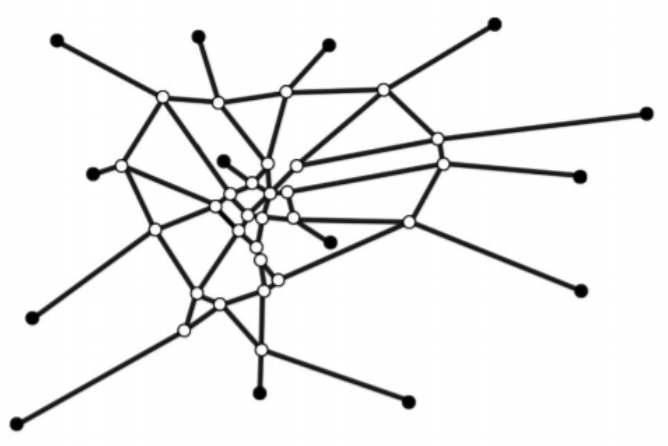

SÃo PAULO - 2030 (STM)

nós $=42$ (14 terminais +28 conexóes $)$ links = 57 ( 56 simples +1 múltiplo)

Fonte: Oakley (2017).

A partir do esquema acima é possível notar a diferença entre as linhas existentes e o ideal projetado, para oferecer uma mobilidade urbana mais eficiente a cidade de São Paulo. Nota-se, portanto, a necessidade da construção de um grande volume de linhas, para expansão da rede de transportes. Pela sua natureza, as obras metroviárias são de extrema complexidade, e envolvem esforços e custos excepcionais (MAINARDI e SACCOMANO, 2013). É necessário, portanto, investir

\footnotetext{
${ }^{2}$ No diagrama da rede do metrô consolidada (2017) de São Paulo, o autor considerou o metrô em operação em 2017, incluindo os trechos em execução das linhas 4-Amarela (Luz-Vila Sônia), 5-Lilás (Capão Redondo - Chácara Klabin) e 6-Laranja (Brasilândia - São Joaquim).
} 
em inovação tecnológica no desenvolvimento de projetos e obras, a fim de diminuir o tempo e os recursos disponibilizados para contratação e produção deste tipo de infraestrutura.

De acordo com Mainardi e Saccomano (2013), a metodologia BIM se apresenta como uma eficiente ferramenta de gestão para a Companhia do Metropolitano de São Paulo (Metrô/SP), pois rompe com antigos paradigmas, e oferece diversas ferramentas de integração e desenvolvimento que se alinham com as mais modernas tecnologias. O estudo se apoia, portanto, no BIM como metodologia, para buscar soluções de aprimoramento e a desburocratização do processo de projeto.

Outra motivação para pesquisa surge da atuação profissional da autora no desenvolvimento de projetos para o Metrô/SP. A partir desta prática notou-se que os projetos de estações metroviária possuem um elevado número de soluções, elementos e materiais padronizados, fato que despertou para a investigação da aproximação da indústria da construção aos processos de fabricação.

Segundo Johnston (2018), a saída para cadeia da construção está na mudança dos processos, no qual a construção se torna mais parecida com a fabricação. A partir de soluções integradas e componentes padronizados se produzirá uma nova maneira de trabalhar, diminuindo a fragmentação do sistema e aproximando os diversos agentes da construção. Para os projetos de infraestrutura, que exigem grandes esforços e investimentos da coletividade, a padronização e a industrialização de sua construção pode significar o aumento da qualidade e a redução do custo das edificações, otimizando desta maneira o grande volume de recursos investidos.

A pesquisa procura aliar a metodologia BIM ao processo de padronização da indústria da construção, propondo o desenvolvimento de um acervo de projetos padronizados de estações de metrô, disponibilizados em uma biblioteca de metacomponentes BIM, com a finalidade de aumentar a qualidade dos projetos e diminuir os prazos de contratação e desenvolvimento de edificações metroviária. Os metacomponentes são módulos compostos por diversos elementos e objetos que formam um modelo completo de partes das edificações. 


\subsection{OBJETIVO}

O objetivo principal da pesquisa é discutir e propor soluções para a introdução de uma biblioteca de metacomponentes BIM no contexto de elaboração e contratação das obras públicas metroviárias.

Em termos gerais, o estudo busca compreender o processo de contratação e o desenvolvimento de projetos no Metrô/SP, para então explorar novas técnicas e processos que possam impactar de maneira positiva a indústria de equipamentos urbanos.

Testando as soluções propostas, e desenvolvendo um metacomponente da biblioteca BIM para identificar os desafios na criação do acervo, e os possíveis benefícios obtidos com a utilização da ferramenta estudada.

Os itens apresentados acima são discriminados na Quadro 1.

Quadro 1 - Objetivos

\begin{tabular}{|c|c|c|c|}
\hline Objetivo & Meio para alcançar & Resultado & Confirmação \\
\hline $\begin{array}{l}\text { Análise e } \\
\text { compreensão do } \\
\text { método de contratação } \\
\text { e desenvolvimento dos } \\
\text { projetos no Metrô/SP }\end{array}$ & $\begin{array}{l}\text { Estudo sobre o } \\
\text { processo licitatório; } \\
\text { Levantamento e } \\
\text { análise do sistema } \\
\text { projetual na } \\
\text { companhia. }\end{array}$ & $\begin{array}{l}\text { Identificação de } \\
\text { inconsistências nos } \\
\text { métodos utilizados. }\end{array}$ & $\begin{array}{l}\text { Cruzamento das } \\
\text { informações } \\
\text { levantadas. }\end{array}$ \\
\hline $\begin{array}{l}\text { Estudar os conceitos } \\
\text { do BIM e tecnologias } \\
\text { de apoio ao processo } \\
\text { de projeto }\end{array}$ & $\begin{array}{l}\text { Leitura e } \\
\text { sistematização da } \\
\text { bibliografia } \\
\text { existente. }\end{array}$ & $\begin{array}{l}\text { Identificação de novas } \\
\text { técnicas; } \\
\text { Aprofundamento dos } \\
\text { conhecimentos para } \\
\text { discussão e } \\
\text { desenvolvimento do } \\
\text { artefato. }\end{array}$ & $\begin{array}{l}\text { Elaboração do } \\
\text { metacomponente e } \\
\text { levantamentos de } \\
\text { dados para ferramenta } \\
\text { proposta. }\end{array}$ \\
\hline $\begin{array}{l}\text { Estudar sobre o } \\
\text { processo de } \\
\text { padronização das } \\
\text { estações de metrô }\end{array}$ & $\begin{array}{l}\text { Leitura e } \\
\text { sistematização da } \\
\text { bibliografia } \\
\text { existente; }\end{array}$ & $\begin{array}{l}\text { Utilização da } \\
\text { padronização como } \\
\text { diretriz para o } \\
\text { desenvolvimento dos } \\
\text { projetos metroviários, e }\end{array}$ & $\begin{array}{l}\text { Estrutura para a } \\
\text { biblioteca de } \\
\text { metacomponentes BIM } \\
\text { do Metrô/SP. }\end{array}$ \\
\hline
\end{tabular}




\begin{tabular}{llll}
\hline Objetivo & Meio para alcançar & Resultado & Confirmação \\
\hline & $\begin{array}{l}\text { Análise dos métodos } \\
\text { construtivos e a } \\
\text { tipologia das } \\
\text { estações existentes. }\end{array}$ & suas limitações. & \\
& Modelar um projeto & Protótipo de & Método de avaliação \\
pesenvolver um & metacomponente da & (entrevistas com \\
metacomponente BIM & & & \\
para estação & estudos e & biblioteca BIM proposta; & especialistas da área) \\
metroviária & levantamentos & Discussões sobre os & \\
& realizados & desafios e benefícios da & \\
& & técnica estudada. & \\
& & & \\
\hline
\end{tabular}

Fonte: Elaboração própria (2018).

\subsection{METODOLOGIA}

O método de pesquisa adotado para realização deste trabalho é a Design Science Research e o estudo de caso. A Design Science é utilizada em pesquisas que buscam melhorar os resultados de sistemas organizacionais e situações existentes através de alterações ou da criação de novos sistemas (LACERDA et al., 2013).

Considerando a necessidade de expansão das linhas de metrô e a demora de construção das mesmas, o estudo busca encontrar soluções para aprimorar o sistema de contratação das obras e desenvolvimento dos projetos licitatórios. O problema central identificado na pesquisa é a ineficiência no processo de contratação e desenvolvimento de projetos metroviários.

As inovações tecnológicas, com destaque a metodologia BIM, aliada ao procedimento de padronização das obras metroviárias, são apontados como possíveis soluções para os problemas da indústria de infraestrutura e desenvolvimento urbano. Será necessário, portanto, desenvolver soluções relacionadas ao BIM, que aplicadas no contexto organizacional de produção de edificações metroviárias possam aperfeiçoar o sistema existente. A 
Figura 4 ilustra o processo de conscientização da problemática envolvida na pesquisa.

Figura 4 - Conscientização do problema
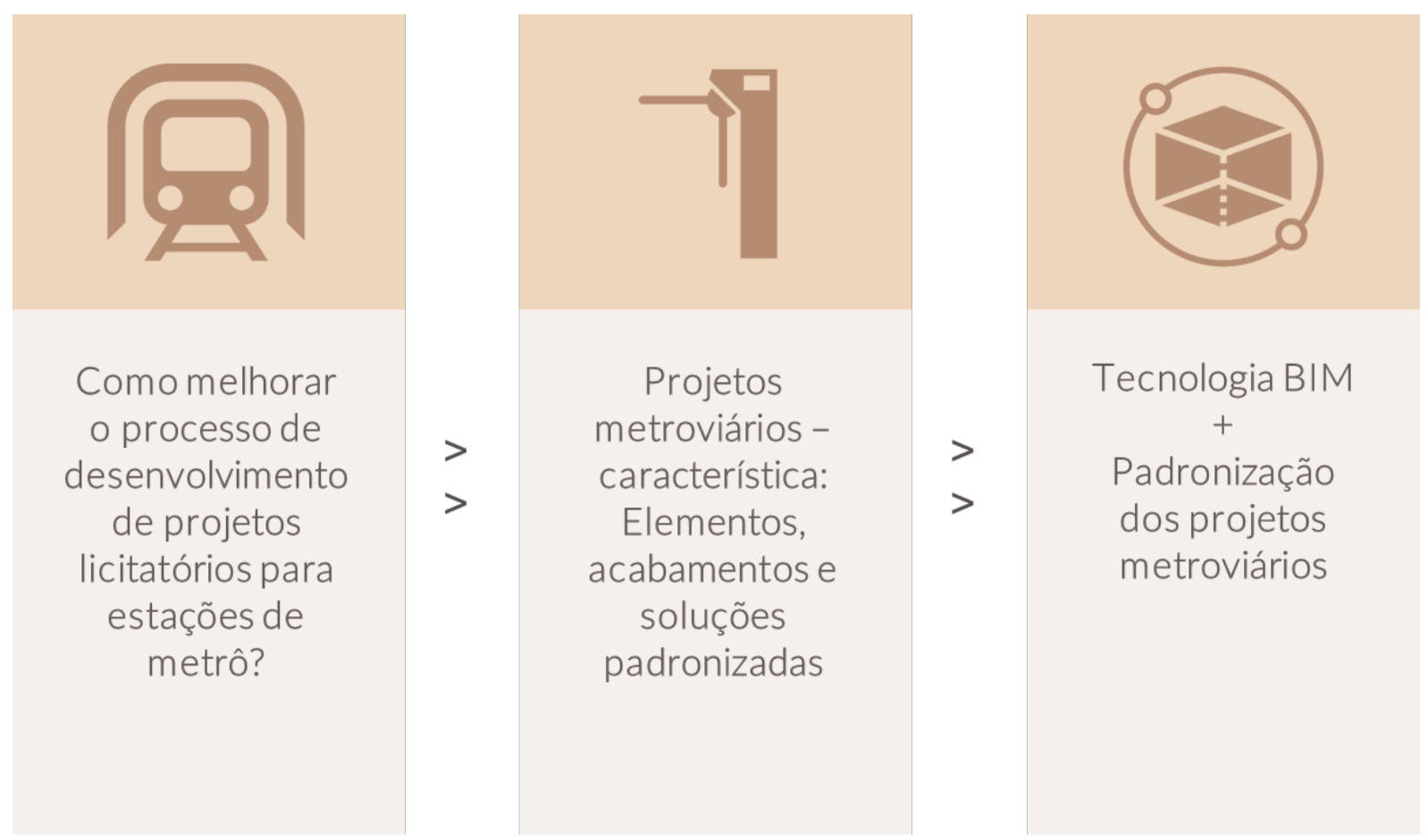

Fonte: Elaboração própria (2019).

Segundo a metodologia proposta, e a fim de estabelecer o quadro de soluções empíricas conhecidas, foi elaborada uma revisão da literatura, contemplando os seguintes temas: processo de contratação das obras públicas, tecnologias de apoio ao processo de projeto, bibliotecas BIM, processo de projeto no Metrô de São Paulo, e por fim industrialização e padronização em estações de metrô. A partir desse estudo foi possível confirmar o a solução (artefato) proposto: biblioteca de metacomponentes BIM para apoiar o processo de desenvolvimento de projetos licitatórios. O esquema desenvolvido para execução da Design Science Research é ilustrado na Figura 5. 
Figura 5 - Esquema de execução da DSR

Conscientização do problema

Processo de licitação para

obras da CMSP
Sugestão

Tecnologia BIM

padronização de componente
Avaliação

Método de validação da biblioteca desenvolvida
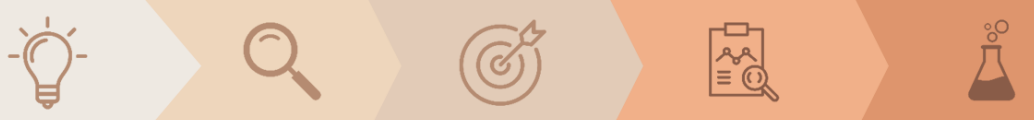

Revisão da literatura

Levantamento de dados e busca por teorias existentes
Desenvolvimento

Criaçāo e discussāo acerca da biblioteca de metacomponentes BIM

\section{Conclusão}

Formalização do processo e divulgação dos resultados

Fonte: Elaboração própria (2019).

O estudo de caso também foi utilizado na pesquisa a fim de confirmar as expectativas com a metodologia BIM, e relatar uma experiência do Metrô/SP relativa ao uso da plataforma.

$\mathrm{Na}$ fase de desenvolvimento do artefato, o primeiro passo foi estruturar a biblioteca BIM a partir de um esquema de padronização para os projetos e tipologias levantadas. Definidos os grupos de metacomponentes, foi eleito um projeto padrão para ser desenvolvido. A escolha do projeto padrão levou em consideração o número de relações entre os componentes e a complexidade do modelo, para que as soluções fossem testadas e os desafios da proposta explicitados.

Esta etapa da pesquisa foi descrita desde a criação do arquivo do modelo BIM até a proposta de articulação dos parâmetros e dados para execução de uma nova ferramenta de apoio ao processo de projeto no Metrô/SP. O detalhamento deste desenvolvimento, incluindo os desafios encontrados, é uma das contribuições do trabalho para o avanço do conhecimento.

A validação da proposta foi realizada a partir de entrevistas com especialistas da área, que atuam em diferentes campos dentro do processo de projeto de estações de metrô. As entrevistas foram semiestruturadas e guiadas por um vídeo de explicação. A finalidade desta etapa foi testar a viabilidade da biblioteca 
de metacomponentes BIM entre os diferentes agentes do processo de projeto, desde a gerência, passando por analistas e projetistas.

A última fase do estudo foi a formalização do processo, expondo as aprendizagens obtidas durante o processo de pesquisa, e declarando fatos de sucesso e pontos de insucesso 

Estação Marienplatz, München

Fonte: Malona (2007). 
CAPÍTULO 2 | REVISÃO BIBLIOGRÁFICA 



\section{2 | REVISÃO BIBLIOGRÁFICA}

O capítulo 2 trata de três temas relevantes para a fundamentação da pesquisa e o desenvolvimento do artefato. $O$ primeiro item estuda o processo licitatório, a fim de compreender as tratativas para viabilização das obras públicas brasileiras e as inconsistências do sistema. Já os demais tópicos são relevantes para as discussões levantadas no capítulo 4 - Biblioteca de metacomponentes BIM para o Metrô/SP. Os estudos sobre a tecnologia BIM de forma geral e o projeto assistido por algoritmos são apresentados no item 2.2. E no último tópico serão abordados processos específicos de aplicação do BIM, apresentando o extrato dos conteúdos estudados sobre as bibliotecas BIM existentes.

\subsection{PROCESSO DE CONTRATAÇÃO DAS OBRAS PÚBLICAS: LICITAÇÕES E CONTRATOS}

Dado que o objetivo da pesquisa é estudar e desenvolver uma biblioteca de metacomponentes BIM para as obras do metrô, é necessário entender o contexto em que esse tipo de obra está inserido. Segundo o art. $6^{\circ}$, seção II, da Lei $\mathrm{N}^{\circ}$ 8.666/1993, uma obra pública é toda construção, reforma, fabricação, recuperação ou ampliação, realizada pelos órgãos e entidades da Administração, pelos próprios meios ou contratada com terceiros. Logo, a construção de uma estação metroviária se enquadra como uma obra pública de infraestrutura.

As obras públicas são construções civis que objetivam desenvolver o Estado, possuem destinação social, são financiadas com fundos públicos e não têm fins lucrativos. Existem diversos tipos de obras públicas: as que visam o desenvolvimento das infraestruturas de transporte (ruas ou estradas, portos, vias ferroviárias, aeroportos, etc.), hidráulicas (represas, depuradoras) ou urbanas (iluminação pública, parques), assim como as que proporcionam a criação de edifícios de interesse social (hospitais, escolas). Sendo assim, fica demonstrada a importância destas construções para o crescimento do país e para a melhoria da qualidade de vida das pessoas (CNJ, 2019). 
Altounian (2016) destaca que o processo de qualquer contratação na qual estejam envolvidos recursos públicos deve ser conduzido com cautela e, no caso específico de obras públicas a cautela deve ser redobrada, devido ao aumento considerável do conjunto de normas e procedimentos. As peculiaridades na execução de cada obra dificultam a obtenção de preços padronizados para as contratações, diferentemente de outros produtos ou serviços encontrados de forma padronizada no mercado. Além disso, a construção de um empreendimento exige o gerenciamento de diversos contratos e procedimentos licitatórios, como, por exemplo: elaboração do projeto básico, execução da obra, implementação das instalações especiais, aquisição de equipamentos e compra de materiais.

Esta primeira parte do capítulo se concentra na compreensão dos processos de contratação das obras públicas, especialmente das obras metroviárias do estado de São Paulo.

\subsubsection{Processo Licitatório}

No Brasil, a contratação das obras e serviços de engenharia é realizada através de licitações ${ }^{3}$, que têm como objetivo assegurar a proposta mais vantajosa para o poder público (evitando sobrepreço ou superfaturamentos nas operações), garantir igualdade de condições a todos que queiram contratar com o Poder Público e promover o desenvolvimento nacional sustentável (CGU, 2019).

Existem diversas estruturas legais que regem os contratos públicos no Brasil. A Figura 6 ilustra um resumo das normas aplicáveis à licitação e contratação de obras do setor público, com destaque para a lei 8.666/1993 que institui as normas para licitações e contratos da Administração Pública (BRASIL, 1993).

\footnotetext{
${ }^{3}$ A licitação é um procedimento administrativo e prévio usado para a contratação com o poder público (Ascom/CGU, 2019). Esse processo é o testemunho documental de todos os passos dados pela Administração rumo à contratação daquele que lhe oferecerá a melhor proposta. Todos os atos praticados em seus autos estarão comprometidos com esta finalidade, sejam decisões, pareceres, levantamentos, estudos, atas, despachos, recursos ou relatórios. (PEREIRA JUNIOR apud ALTOUNIAN, 2016).
} 
Figura 6 - Conjunto normativo aplicado à licitação e contratação de obra pública

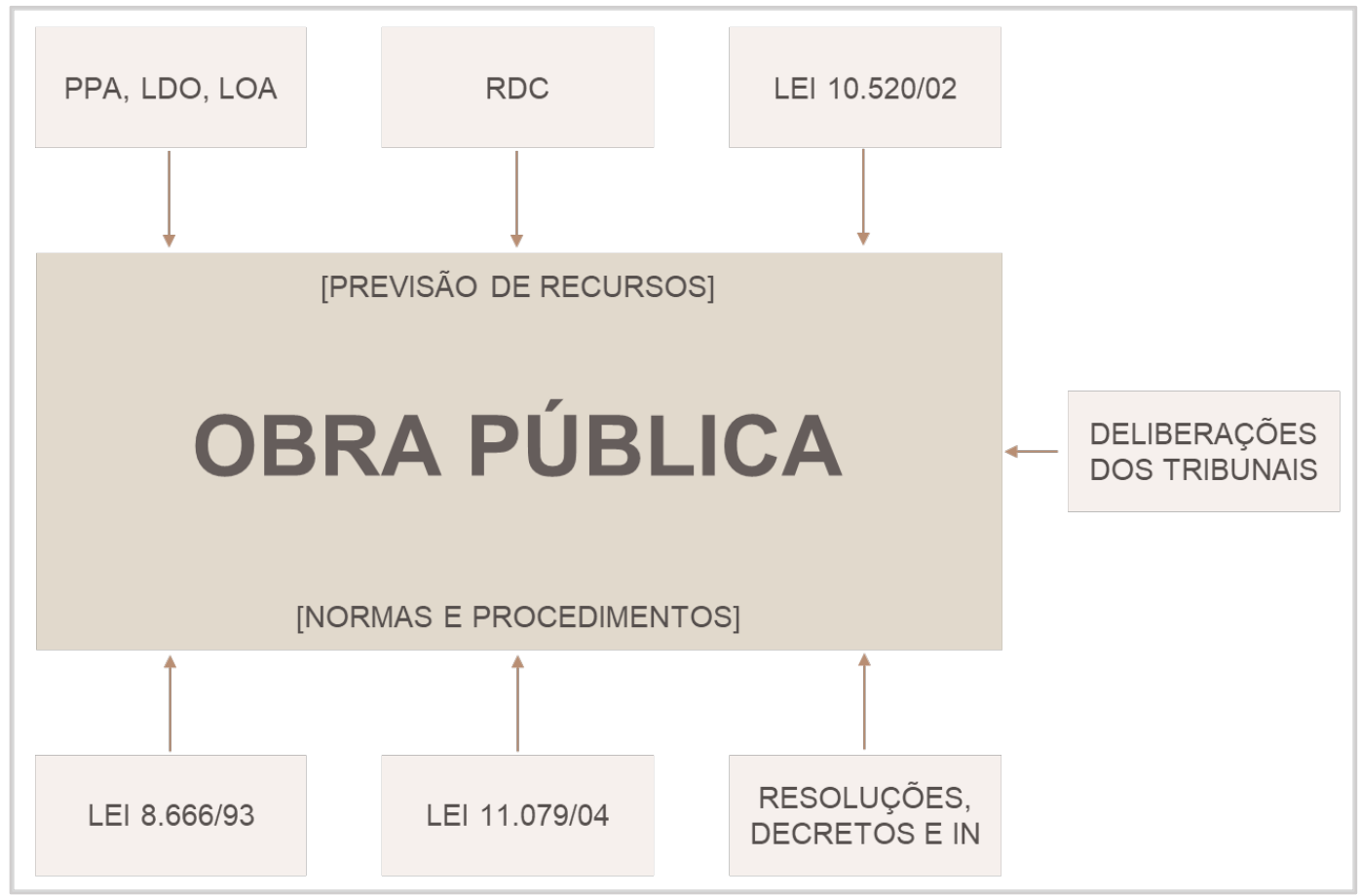

Fonte: Elaboração própria, baseado em ALTOUNIAN (2016).

O Plano Plurianual (PPA), a Lei de Diretrizes Orçamentárias (LDO) e a Lei Orçamentária Anual (LOA) procuram direcionar metas e receitas, além de normatizar o planejamento das ações do Governo. O Regime Diferenciado de Contratações Públicas (RDC) foi criado com o objetivo de otimizar as licitações e contratos para as obras dos eventos esportivos realizados no Brasil entre 2014 e 2016, como os Jogos Olímpicos e a Copa do Mundo. Existem também diversas leis relacionadas ao exercício da engenharia e arquitetura; decretos, instruções normativas e resoluções direcionadas a elaboração de orçamentos, contratação dos serviços e a destinação dos recursos para as obras de engenharia (ALTOUNIAN, 2016).

Algumas obras de infraestrutura são contratadas no regime de parceriapúblico-privada - PPP, e são regidas pela lei 11.079/2004. De acordo com Portugal (2017), a forma de remuneração do agente privado é o que difere uma PPP de uma concessão comum. Na PPP, o governo é quem predominantemente remunera o agente privado, já na concessão a remuneração se dá exclusivamente por cobrança de tarifas dos usuários. 
A lei 10.520/2002, que trata de uma modalidade de licitação denominada pregão, é utilizada em caso de despesas e serviços mais comuns, ou seja, "aqueles cujos padrões de desempenho e qualidade possam ser objetivamente definidos pelo edital, por meio de especificações usuais no mercado" (BRASIL, 2002).

Existem seis modalidades de licitação: concorrência pública, tomada de preços, convite, concurso, pregão eletrônico ou leilão. Para definição da modalidade de licitação são estabelecidos dois critérios: valor e natureza do objeto (BRASIL, 1993). O processo licitatório costuma ser dividido em duas fases, a interna e a externa. A fase interna é desenvolvida pela Administração até a publicação do edital ou entrega do convite, deste momento até a contratação do empreendimento considera-se como fase externa. As etapas do processo de licitação, contratação e utilização de um empreendimento público são apresentadas na Figura 7.

Figura 7 - Procedimentos para viabilização de obras públicas ${ }^{4}$

\begin{tabular}{|c|c|c|c|c|}
\hline $\begin{array}{l}\text { FASE PRELIMINARÀ } \\
\text { LICITAÇÃO }\end{array}$ & $\begin{array}{l}\text { FASE INTERNA DA } \\
\text { LICITAÇÃO }\end{array}$ & $\begin{array}{l}\text { FASE EXTERNA DA } \\
\text { LICITAÇẪO }\end{array}$ & | FASE CONTRATUAL & $\begin{array}{l}\text { FASE POSTERIORÀ } \\
\text { CONTRATAÇÃOO }\end{array}$ \\
\hline $\begin{array}{l}\text { Programa de } \\
\text { necessidades; } \\
\text { Estudo de } \\
\text { viabilidade; } \\
\text { Anteprojeto. }\end{array}$ & $\begin{array}{l}\text { Projeto Básico; } \\
\text { Licenciamento } \\
\text { ambiental; } \\
\text { Preparação do edital } \\
\text { ou convite; } \\
\text { Projeto Executivo. }\end{array}$ & 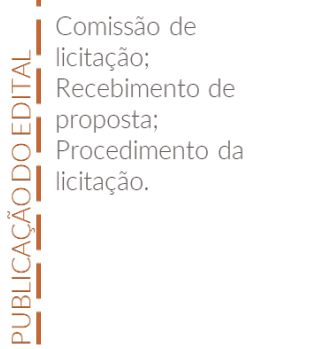 & 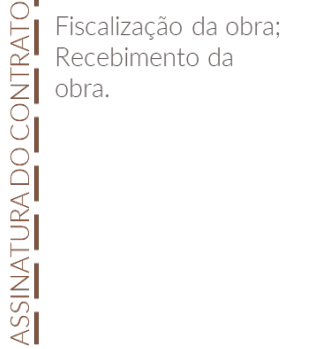 & $\begin{array}{l}\text { Operação; } \\
\text { Manutenção. }\end{array}$ \\
\hline
\end{tabular}

Fonte: Elaboração própria, baseada na Cartilha Obras Pública do TCU (TCU,2013).

A fase preliminar à licitação sinaliza a viabilidade do empreendimento, identificando sua necessidade, estimando recursos e selecionando a melhor alternativa para o atendimento ao interesse público. Define-se, portanto, a concepção ampla da obra através do programa de necessidades, dos aspectos técnicos, ambiental e socioeconômico, da avaliação de custo sobre o metro quadrado da edificação, e do seu anteprojeto (TCU,2013).

A fase interna da licitação contempla a preparação para a publicação do edital de licitação, na qual são detalhadas as especificações do objeto e definidos os

4 A Lei $n^{\circ} 8.666 / 93$ permite, excepcionalmente, que o projeto executivo seja desenvolvido simultaneamente à realização da obra. (BRASIL, 1993). 
requisitos para o recebimento das propostas. A perfeita caracterização do objeto e a previsão adequada de recursos são as principais diretrizes para a licitação de obras e serviços (ALTOUNIAN, 2016). O Quadro 2 apresenta a estrutura do edital e as informações obrigatórias estabelecidas pela Lei n 8.666/1993.

Quadro 2- Elementos exigidos na elaboração do edital pela Lei nº 8.666/1993

\begin{tabular}{|c|c|c|}
\hline & Artigo & Conteúdo \\
\hline CARACTERIZAÇÃO DA & & - Objeto da licitação \\
\hline OBRA & $\begin{array}{l}7^{\circ}, \S 2^{\circ}, \text { incisos I e II, e } 40, \\
\text { incisos I e V, e } \S 2^{\circ}\end{array}$ & $\begin{array}{l}\text { - Projeto básico e/ou executivo } \\
\text { - Orçamento estimado em planilha } \\
\text { de quantitativo e preços unitários }\end{array}$ \\
\hline \multicolumn{2}{|l|}{ PREVISÃO DE RECURSOS } & - Previsão de recursos \\
\hline \multirow[t]{2}{*}{ ORÇAMENTÁRIOS } & $7^{\circ}, \S 2^{\circ}$, incisos III e IV & orçamentários \\
\hline & & - Produto contemplado no PPA \\
\hline REGRAS PARA & & - Modalidade \\
\hline ESTRUTURAÇÃO DA & & - Parcelamento \\
\hline LICITAÇÃO & & - Tipo \\
\hline REGRAS PARA A & & - Condições de pagamento \\
\hline \multirow[t]{3}{*}{ CONTRATAÇÃO } & 40, incisos IX, XI, XIV & - Critério de reajuste \\
\hline & e XVI, e $\S 2^{\circ}$ & $\begin{array}{l}\text { - Condições de recebimento do } \\
\text { objeto }\end{array}$ \\
\hline & & - Minuta do contrato \\
\hline \multicolumn{2}{|l|}{ REGRAS PARA A } & \\
\hline \multirow{2}{*}{$\begin{array}{l}\text { HABILITAÇÃO DOS } \\
\text { INTERESSADOS }\end{array}$} & 40 , inciso VI & - Condições para participação da \\
\hline & & Icıtaçao \\
\hline REGRAS PARA O & & - Critério para julgamento, com \\
\hline JULGAMENTO & 40, incisos VII e X & $\begin{array}{l}\text { disposições claras e parâmetros } \\
\text { objetivos }\end{array}$ \\
\hline
\end{tabular}


Artigo

PROCEDIMENTOS E

INFORMAÇÕES

COMPLEMENTARES

\section{Conteúdo}

\author{
- Prazo e condições para \\ assinatura do contrato ou retirada \\ dos instrumentos \\ - Sanções para inadimplemento
}

40, incisos II, III, IV,

- Local onde o projeto poderá ser

VIII, XV

Fonte: Altounian (2016).

A elaboração dos projetos, o licenciamento ambiental e o orçamento detalhado da edificação estão compreendidos na fase interna do procedimento licitatório. Em casos nos quais o órgão público não dispõe de corpo técnico especializado, licitações especificas são realizadas para contratar empresas para elaboração dos serviços.

Conforme citado acima, a fase externa da licitação começa com a publicação do edital e termina com a assinatura do contrato para a execução da obra. A Figura 8 detalha os procedimentos realizados após a publicação do edital até a fase de contratual.

Figura 8 - Etapas da fase externa da licitação

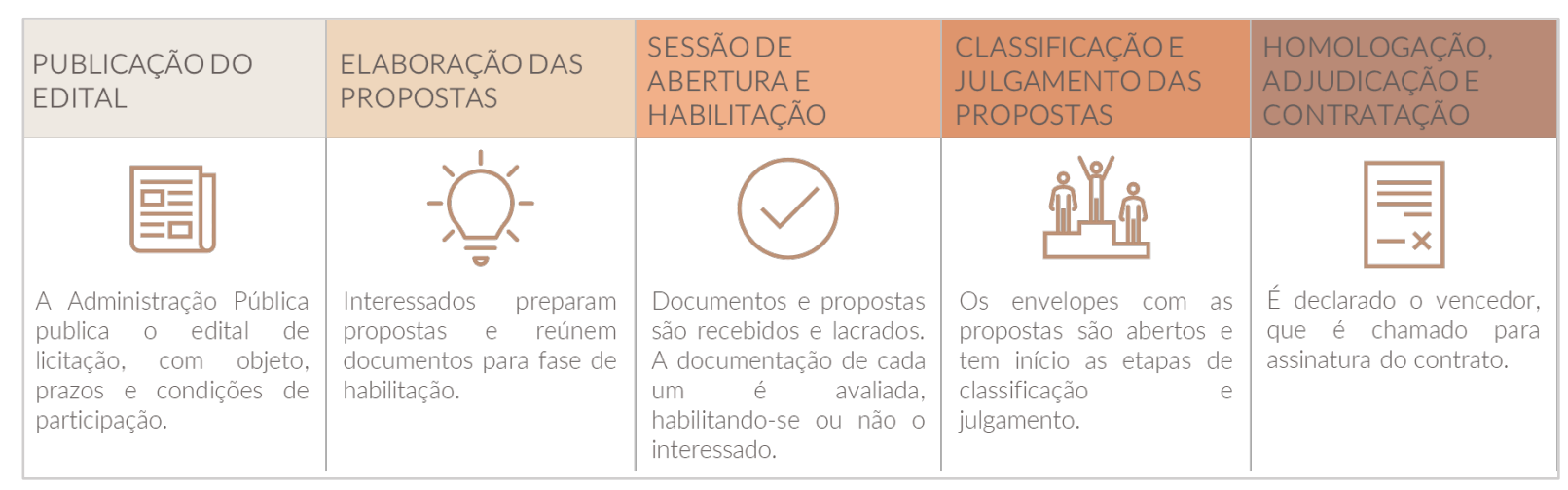

Fonte: CGU (2019). 
A fase contratual compreende desde a assinatura do contrato e a emissão da ordem de serviço até o recebimento da obra. Após a conclusão do empreendimento, a Administração Pública deve adotar medidas para manutenção e operação do mesmo.

Ainda que as etapas de licitação apresentadas anteriormente sejam as mais comuns, as empresas públicas e de sociedade mista da União, dos Estados, do Distrito Federal e dos Municípios, que são regulamentadas pela Lei $n^{\circ} 13.303$, de 30 de junho de 2016, podem seguir a seus próprios procedimentos licitatórios, desde que garantidos os preceitos da Lei $n^{\circ}$ 13.303/2016. Além disso, devem atender, também, aos artigos 89 a 99 da Lei 8.666/1993, que tratam dos crimes e das penas (BRASIL, 2016). Aplicam-se, ainda, à essas empresas as disposições da Lei $n^{\circ}$ 6.404/1976 e as normas da Comissão de Valores Mobiliários.

\subsubsection{Licitação no Metrô-SP}

A Companhia do Metropolitano de São Paulo - Metrô/SP, objeto desta pesquisa, possui um regulamento próprio, nos termos da Lei $n^{0} 13.303 / 2016$, que institui o procedimento de licitações e contratos da companhia, além de suas relações com fornecedores, contratados, parceiros e doadores (CMSP, 2019a).

O documento apresenta diversos regimes de contratação possíveis: empreitada por preço unitário, empreitada por preço global, tarefa, empreitada integral, contratação semi-integrada e integrada. A descrição e as informações necessárias para cada regime de contratação são apresentadas na Quadro 3. Os regimes são escolhidos de acordo com (CMSP, 2019a):
a) Escala da obra ou do serviço de engenharia a ser prestado;
b) Precisão do quantitativo e orçamento inerente ao projeto básico;
c) Prazo disponível para operação do empreendimento;
d) Natureza intelectual e de inovação tecnológica do objeto licitado. 
Quadro 3 - Regimes de contratações do Metrô/SP

\begin{tabular}{llll}
\hline & & & Informações \\
Regime de & Descrição & Forma de & para \\
contrato & & remuneração & convocação
\end{tabular}

\section{TAREFA}

Mão de obra (profissionais autônomos ou

pequenas empresas) para pequenos

Preço certo

trabalhos de curta duração

\begin{tabular}{llll}
\hline EMPREITADA & Unidades determinadas, ou seja, nos casos & & \\
POR PREÇO & em que os objetos, por sua natureza, & Preço certo & Projeto Básico \\
UNITÁRIO & possuam imprecisão inerente de & \\
& quantitativos em seus itens orçamentários. &
\end{tabular}

\begin{tabular}{llll}
\hline EMPREITADA & Quando for possível definir previamente no & \\
POR PREÇO & projeto básico, com boa margem de & Preço certo e & Projeto Básico \\
GLOBAL & precisão, as quantidades dos serviços a & total & \\
& serem posteriormente executados na fase & & \\
& contratual. &
\end{tabular}

\section{EMPREITADA Empreendimento em sua integralidade:}

INTEGRAL Obra, serviços e instalações. Nos casos em

que o contratante necessite receber $o$

empreendimento, normalmente de alta

Projeto Básico

complexidade, em condição de operação

imediata.

\begin{tabular}{lll}
\hline CONTRATAÇÃo & Projeto executivo e execução de obras e & Projeto Básico \\
SEMI- & serviços. Quando for possível definir & (poderá ser \\
INTEGRADA & previamente no projeto básico as & alterado com \\
& quantidades dos serviços a serem & justificativas) \\
& posteriormente executados na fase & Documento \\
& contratual, em obra ou serviço de & técnico \\
& engenharia que possa ser executado com & Matriz de $^{5}$ \\
& diferentes metodologias ou tecnologias. & riscos $^{6}$
\end{tabular}

5 O documento técnico define as frações do empreendimento em que haverá liberdade de as contratadas inovarem em soluções metodológicas ou tecnológicas, seja em termos de modificação das soluções previamente delineadas no anteprojeto ou no projeto básico da licitação, seja em termos de detalhamento dos sistemas e procedimentos construtivos previstos nessas peças técnicas (BRASIL, 2016). 


\section{Regime de}

contrato

\section{Descrição}

Forma de

remuneração
Informações

para

convocação

CONTRATAÇÃo Projetos básico e executivo, execução de

INTEGRADA obras e serviços. Quando a obra ou o

serviço de engenharia for de natureza

Anteprojeto

predominantemente intelectual e de

Documento

inovação tecnológica do objeto licitado ou

técnico

puder ser executado com diferentes

metodologias ou tecnologias de domínio

Matriz de riscos

restrito no mercado.

Fonte: Elaboração própria, baseado na Lei n 13.303/2016.

O art. 42 da Lei $n^{\circ} 13.303 / 2016$, institui que as empresas públicas ou mistas devem utilizar, no caso das obras e serviços de engenharia, a contratação semi-integrada. Neste regime de contrato, as empresas contratadas são responsáveis pelo desenvolvimento do projeto executivo, execução da obra e por todas as operações necessárias para a entrega final do objeto. Entretanto, para convocação de licitação nesta modalidade de contrato, conforme apresentado na Quadro 3, é necessário elaborar previamente o projeto básico do empreendimento.

\section{A Lei 8.666/1993 define o projeto básico como:}

Um conjunto de elementos necessários e suficientes, com nível de precisão adequado, para caracterizar a obra ou serviço, ou complexo de obras ou serviços objeto da licitação, elaborado com base nas indicações dos estudos técnicos preliminares, que assegurem a viabilidade técnica e o adequado tratamento do impacto ambiental do empreendimento, e que possibilite a avaliação do custo da obra e a definição dos métodos e do prazo de execução (BRASIL, 1993).

O regulamento do Metrô/SP aponta no art. $22, \S 1^{\circ}$, a obrigatoriedade da elaboração do projeto básico antes da contratação de obras e serviços, com

\footnotetext{
${ }^{6}$ Matriz de Risco é uma cláusula contratual definidora de riscos e responsabilidades entre as partes e caracterizadora do equilíbrio econômico-financeiro inicial do contrato, em termos de ônus financeiro decorrente de eventos supervenientes à contratação (BRASIL, 2016).
} 
exceção daquelas em que for adotado o regime de contratação integrada ${ }^{7}$ (CMSP, 2019a). Além de conter os subsídios necessários para a montagem do plano de licitação e gestão da obra, o projeto básico oferece o orçamento detalhado do custo global da obra (BRASIL, 1993). Esse orçamento de referência é obtido a partir do quantitativo do projeto básico e de custos de insumos ou serviços no Sistema Nacional de Pesquisa de Custos e Índices da Construção Civil (SINAPI), ou em caso de inviabilidade, em tabela de referência formalmente aprovada por órgãos ou entidades públicas, publicações especializadas, banco de dados e sistemas específicos (BRASIL, 2016).

\subsubsection{Discussões sobre o processo licitatório}

Os itens acima descrevem, baseado na legislação atual, os procedimentos para contratar e executar as obras públicas brasileiras. Entretanto, não é rara a constatação de inconsistências no processo e graves irregularidades na gestão de recursos canalizados para essa área, como superfaturamento, demora na conclusão ou, até mesmo, abandono dos empreendimentos.

Segundo levantamento da FIESP (2010) os prejuízos econômicos que a corrupção causa no Brasil representa de 1,38\% a 2,30\% do seu PIB, algo em torno de 41,5 a 69,1 bilhões de reais, para dados de 2008. Atualizando os dados para o PIB de 2016 (6.266 bilhões de reais), a estimativa de perdas com a corrupção representaria 200 bilhões de reais ao ano, aproximadamente $3 \%$ do PIB (PORTUGAL, 2017).

Em São Paulo, o escândalo das licitações no transporte público aponta a existência de um esquema ilegal desde 1997, que consiste em um esquema de pagamentos de propina e formação de cartel para disputar licitações do Metrô e da CPTM. Nas estimativas do Ministério Público, o esquema pode ter dado prejuízos de mais de 800 milhões de reais aos cofres públicos (ALESSI, 2016).

\footnotetext{
${ }^{7}$ Segundo o regulamento, o regime de contratação integrada deve ser utilizado quando a obra ou o serviço de engenharia for de natureza predominantemente intelectual e de inovação tecnológica do objeto licitado ou puder ser executado com diferentes metodologias ou tecnologias de domínio restrito no mercado (CMSP, 2019a).
} 
Além da corrupção, facilitada pela falta de transparência nos processos administrativos, são apontadas outras causas para a ineficiência das licitações, como por exemplo a hierarquização e burocratização dos processos internos nos órgãos públicos, aliados com a precariedade das informações iniciais dos projetos e a resistência a novos processos. Na esfera pública as obras de infraestrutura tendem também a serem vinculadas a gestões partidárias, que regulam diretrizes e orçamentos para projetos específicos, quebrando muitas vezes a linearidade das ações e comprometendo o planejamento adequado da cidade.

O Ministério da Indústria, Comércio Exterior e Serviços - MDIC aponta na estratégia BIM BR preocupação com a confiabilidade dos cronogramas e orçamentos das obras, a transparência nos processos licitatórios e a quantidade de aditivos contratuais de alteração do projeto, de elevação de valor e de prorrogação de prazo de conclusão e de entrega das obras (ABDI,2017b). Em 2018, o Tribunal de Contas da União (TCU) identificou 14.403 obras paradas em todo Brasil e as principais causas apontadas são falhas no projeto e a dificuldade em obter licenciamento ambiental (AGÊNCIA CÂMARA, 2019).

O projeto é um dos elementos centrais da construção civil, responsável por informar as características físicas do produto, garantir qualidade, racionalidade e a construtibilidade do empreendimento. É também nesta fase que podem ser introduzidas inovações tecnológicas e possibilidades de ganhos financeiros por meio da redução do desperdício e das patologias construtivas (OLIVEIRA; MELHADO, 2006). Apesar de o projeto ser indispensável para o processo de contratação, o atropelamento das etapas de projeto é apontado como uma das causas para os problemas de gestão das obras públicas (RASMUSSEN, 2013).

As falhas na elaboração dos projetos estão altamente relacionadas aos principais atributos causadores dos aditivos contratuais de prazo e valor nas obras de entidades públicas (SANTOS, 2015). A lei 8.666/1993 não estabelece o nível de precisão do projeto básico, e como consequência desse grau de incerteza, permite 
um aumento ou diminuição de $25 \%$ no custo, em casos de edifícios novos, e $50 \%$ em reformas ${ }^{8}$.

Segundo Altounian (2016), o projeto básico é a peça mais importante para a condução da licitação. No entanto, o autor acrescenta que falhas na definição desse projeto trarão enormes dificuldades ao gerenciamento das obras sob os aspectos de prazo, custo e qualidade.

Outro ponto de discussão nas licitações é o regime de contratação. O projeto de Lei $\mathrm{n}^{\circ}$ 1.292/95, que atualmente aguarda apreciação pelo Senado Federal, propõe uma nova lei para as contratações públicas, substituindo a Lei $\mathrm{n}^{\circ}$ 8.666/93 (Lei Geral de Licitações), a Lei n 10.520/2002 (Lei do Pregão), e a Lei $n^{\circ}$ 12.462/2011 (Regime Diferenciado de Contratação Pública), incorporando a contratação integrada.

Diante deste cenário, esta pesquisa adotará o processo licitatório atualmente vigente para o desenvolvimento do artefato proposto, considerando os estudos iniciais e o projeto básico como peça chave para melhorar os procedimentos licitatórios. É importante destacar que as proposições realizadas por esta pesquisa são idealizadas para atender o empreendimento desde a sua concepção até a fase da obra. No caso de alteração na legislação seria necessário adequar e inserir mais informações aos componentes da biblioteca de metacomponentes proposta neste trabalho.

A partir das fragilidades do sistema de licitações expostas anteriormente, a pesquisa sustenta que ao conferir maior qualidade e controle de informações através da utilização da metodologia BIM na elaboração de projetos e obras e da aplicação de processos de padronização de projetos públicos será possível agregar confiabilidade e agilidade ao processo licitatório.

\footnotetext{
8 Art. 65. § 10 O contratado fica obrigado a aceitar, nas mesmas condições contratuais, os acréscimos ou supressões que se fizerem nas obras, serviços ou compras, até $25 \%$ (vinte e cinco por cento) do valor inicial atualizado do contrato, e, no caso particular de reforma de edifício ou de equipamento, até o limite de 50\% (cinquenta por cento) para os seus acréscimos (BRASIL,1993).
} 


\subsection{TECNOLOGIAS DE APOIO AO PROCESSO DE PROJETO}

A pesquisa procura compilar nas referências bibliográficas as informações que conduziram o desenvolvimento do artefato aqui proposto, uma biblioteca de metacomponentes BIM. Além de compreender as características específicas das obras públicas dentro do seu sistema de contratação e execução, conforme discutido no item 2.1, foi necessário estudar tecnologias que possam viabilizar a biblioteca de metacomponentes BIM como uma ferramenta de projeto para o Metrô/SP.

Portanto, neste item a seguir, serão abordados os seguintes temas: modelagem paramétrica, junto com a metodologia BIM e projeto assistido por algoritmos. O desenvolvimento e a utilização da biblioteca proposta se apoiam, portanto, na modelagem paramétrica, como ponto de partida para a representação dos projetos padronizados do Metrô/SP, através da metodologia BIM, a fim de estruturar as informações dos modelos, e no projeto assistido por algoritmos, como forma de viabilizar a automação dos metacomponentes.

\subsubsection{Modelagem paramétrica e a metodologia BIM}

A modelagem paramétrica baseada em objetos foi desenvolvida originalmente na década de 80 . Ela se refere a modelos 3D, no qual objetos e/ou elementos são manipulados usando parâmetros e regras, que determinam sua geometria (EASTMAN et al, 2014). O modelo de dados de um edifício, por exemplo, é construído a partir desses elementos e das suas relações. Todas as informações embebidas em um modelo paramétrico podem ser extraídas e utilizadas para vários propósitos: documentação, visualização, análise, entre outros (MANZIONE, 2013).

A partir de uma estrutura baseada em parâmetros e hierarquia, embutida em programas gráficos computacionais, é possível programar as dependências entre objetos, por meio do uso de variáveis (FLORIO, 2009). Além de dados geométricos, esses modelos também armazenam outras propriedades e características, como custo, fabricante, classificação de incêndio, etc.

Os modelos paramétricos não representam objetos por superfícies e propriedades fixas. Seus componentes seguem regras de 'herança' (tipos e 
instâncias) e 'encapsulamento' (objetos dentro de objetos), como por exemplo uma parede cortina, que é composta de painéis e montantes (BIMDICTIONARY, 2020).

O projeto paramétrico é, portanto, o resultado de um número de condições pré-estabelecidas pelo usuário, onde mudanças feitas em um parâmetro afetarão as funções que dependem dele (FLORIO, 2009). Os parâmetros e as regras permitem que os objetos se atualizem automaticamente de acordo com o controle do usuário ou mudanças de contexto (EASTMAN, 2014).

A metodologia BIM (Building Information Modeling) responsável pela gestão da informação é baseada em um conjunto de modelos digitais, compartilháveis, tridimensionais e semanticamente ricos (MANZIONE, 2013). Segundo Underwood e Isikdag (2010) os modelos da informação da construção (Building Information Models) possuem as seguintes características:

a) Orientado ao Objeto 9 ;

b) Ricos em dados (apresentam as características físicas e funcionais dos edifícios, além do estado dos elementos do mesmo);

c) Tridimensionais (representam a geometria do edifício em três dimensões);

d) Elementos espacialmente relacionados de maneira hierárquica;

e) Semanticamente ricos;

f) Capazes de suportar vistas (as vistas são subconjuntos do modelo que podem ser geradas com base no modelo principal).

A modelagem paramétrica tem sido utilizada pelas empresas para embutir regras de projeto, de engenharia e de fabricação nos modelos de seus produtos. Desta forma são embutidos conhecimentos corporativos baseado em esforços anteriores nos projetos, produção, montagem e na manutenção acerca do que funciona e do que não funciona. Por exemplo, quando a Boeing empreendeu o projeto do 777 , eles determinaram as regras pelas quais os interiores de seu avião deveriam ser definidos, para fins de aparência, fabricação e montagem (EASTMAN et al., 2014).

\footnotetext{
${ }^{9}$ É um tipo de programação, baseado na composição e interação entre diversas unidades chamadas de 'objetos'.
} 


\subsubsection{Objetos ou componentes BIM}

De acordo com a ABNT NBR ISO 12006-2 (2010), componente BIM é qualquer parte do mundo perceptível ou concebível, uma simulação de um objeto construído ou a construir.

$\mathrm{O}$ ato de projetar se constitui a partir da criação e da manipulação das relações incorporadas no modelo da construção. Portanto os parâmetros fornecem aos projetistas acessos diretos a esses relacionamentos e são um jeito natural e intuitivo de pensar sobre o edifício utilizando um computador (MANZIONE, 2013).

Os parâmetros são números ou características utilizadas para determinar o comportamento de um objeto e definir relacionamentos entre os componentes do modelo. Existem parâmetros que armazenam informações sobre a forma do elemento - posição, dimensões, ou transformações geométricas -, e sobre as suas características funcionais - material, especificações, requisitos legais, procedimento de montagem, preço, fabricante, etc. (MANZIONE, 2013).

Objetos paramétricos são definidos usando parâmetros que envolvem distâncias, ângulos e regras como: ligado a, paralelo a e distante de. A maioria permite condições "se-então". Sua definição é uma tarefa complexa, embutindo conhecimento sobre como eles devem comportar-se em diferentes contextos. Cada ferramenta BIM de projeto oferece famílias de objetos predefinidas que podem ser prontamente aplicadas aos projetos de edificações. No entanto essas famílias representam de forma mais completa a prática padrão, excluindo objetos necessários em tipos especiais de construção (EASTMAN et al., 2014).

\subsubsection{Padronização de modelos BIM}

A padronização no BIM é necessária para a troca de informações entre os aplicativos utilizados na indústria da construção. Contudo, além dos sistemas computacionais serem capazes de trocar informações, a interoperabilidade semântica deve garantir a interpretação automática das informações de maneira 
significativa e precisa, a fim de produzir resultados úteis e sem ambiguidade: o que é enviado é igual ao que é entendido (POLJANŠEK, 2017).

A interoperabilidade pode ser alcançada sem a padronização, mas condiciona o projeto a concordar com as suas próprias regras, não garantindo a utilização das informações durante todo o ciclo de vida do edifício. Uma interoperabilidade eficiente baseada em objetos requer padrões de modelo de dados, do dicionário de dados e de processos, conforme especificado na Quadro 4 .

Quadro 4 - Conjunto de padrões para interoperabilidade baseada em objetos

\section{Padrão Objetivo}

$\begin{array}{ll}\text { Modelo de } & \text { Especificar a estrutura de dados para entidades, geometria e propriedades } \\ \text { dados } & \text { relacionadas, além de classificação para troca de modelos de dados. O modelo de } \\ \text { dados garante a troca de informações baseadas em objetos }\end{array}$

Dicionário de Especificar a estrutura de dados para definir conceitos semânticos de dados Dados (entidade, propriedade, classificação etc.) e as relações entre eles.
Processo
Especificar como descrever as informações necessárias para dar suporte a um determinado processo.

Fonte: Poljanšek (2017).

A padronização internacional BIM é um processo complexo que envolve diversas organizações. Na comunidade europeia por exemplo, além da organização de normatização internacional (ISO) e do comitê técnico do órgão de normatização europeu (CEN), o estabelecimento das normas é discutido com entidades industriais e com a BuildingSMART, como mostra a Figura 9, com o objetivo de garantir integralidade e aceitação dos padrões adotados. 
Figura 9 - Padronização internacional BIM

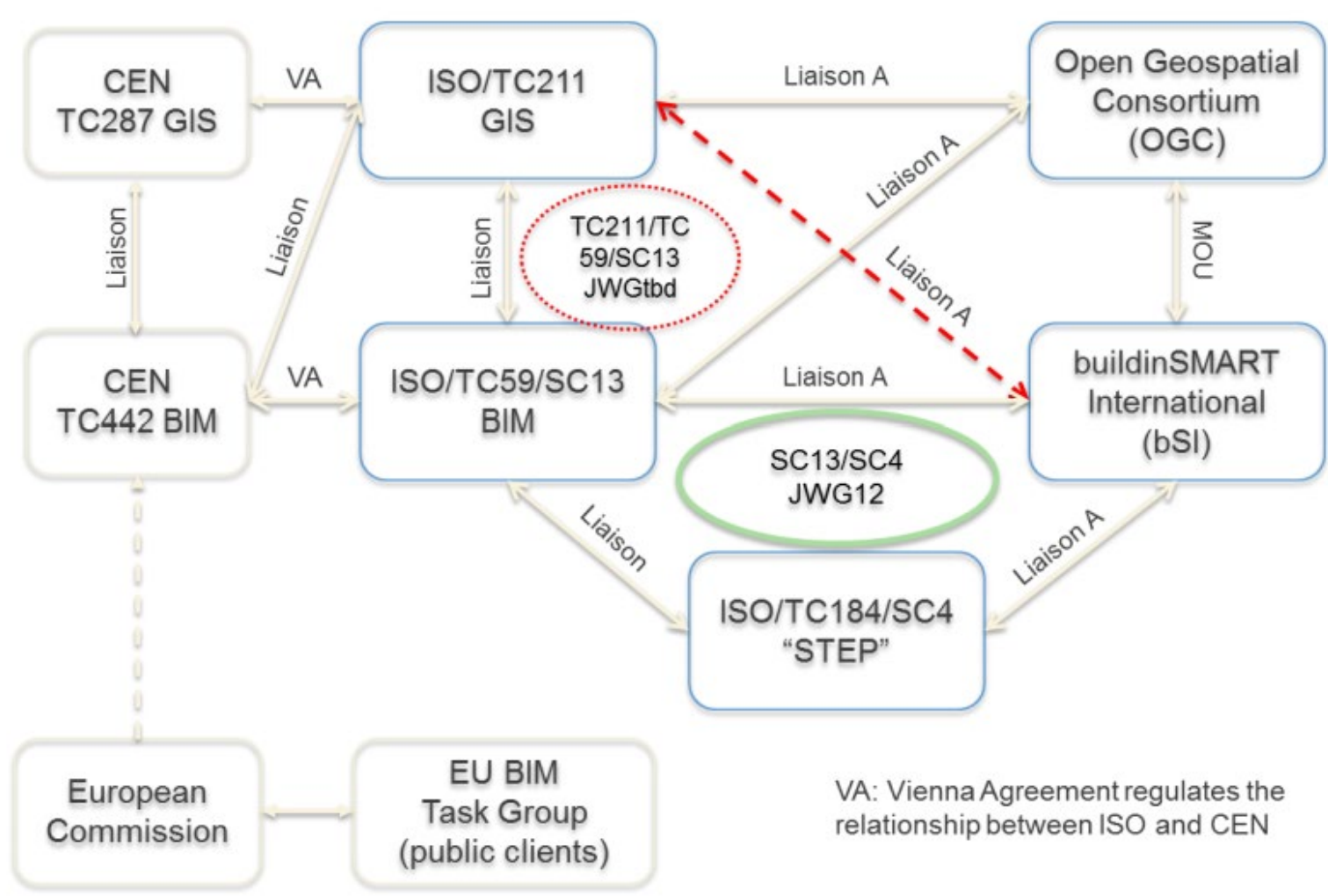

Fonte: Poljanšek (2017).

A organização BuildingSMART desenvolveu e mantem o IFC (Industry Foundation Classes) como um formato neutro e aberto para o modelo de dados BIM. Outro trabalho importante sobre padronização BIM é o dicionário de dados e processos "International Framework for Dictionaries Library".

Para a área de infraestrutura o sistema de informações geográficas (GIS) é um elemento chave, apontando a necessidade de integração entre o BIM e GIS. Ambas as tecnologias utilizam formatos abertos e padrão, porém diferentes e, atualmente, sem tradução.

Embora existam diversos guias, protocolos e padrões para definir o conteúdo de informações nos modelos BIM, percebe-se uma crescente disparidade entre eles. De acordo com Succar (2016), há uma variedade de esquemas concorrentes para definir o conteúdo da informação na escala de objeto, como por 
exemplo: Níveis de Desenvolvimento (ND) ${ }^{10}$, Níveis de Detalhe e Níveis de Informação, além de especificações de gerenciamento de informações para atividades de projeto, construção e pós-construção, como por exemplo: PAS 11922:2013 11 e COBie. Contudo, existem apenas alguns poucos guias que tratam da predefinição e da pós-medição dos resultados do projeto.

\subsubsection{Projeto assistido por algoritmos (AAD)}

A adoção de tecnologias CAD (Computer Aided Design ou design auxiliado por computador) em práticas de projeto trouxe vantagens relacionadas à eficiência e precisão. Recentemente novos modos de usar os computadores têm aberto territórios, em especial para a exploração de possibilidades de projeto. Para além dos sistemas CAD convencionais, as práticas de AAD (Algorithm Aided Design), trazem a possibilidade de processos capazes de gerar uma variedade de modelos, uma vez que são capazes de apoiar o desenvolvimento flexível de geometrias complexas e formas avançadas (MINEIRO e MAGALHÃES, 2019).

O AAD consiste em uma abordagem de projeto assistido por algoritmos. Slunecko (2020) define "algoritmo" como um conjunto de operações a serem realizadas para produzir uma solução de acordo com determinadas condições, ou para executar uma tarefa específica definindo um grupo preciso de instruções. Os algoritmos dividem problemas complexos em etapas menores, que podem ser calculadas. Para que um algoritmo opere adequadamente, é necessário cumprir vários critérios; as instruções devem ser inequívocas, a entrada e a saída devem ser claramente definidas e as etapas de instrução devem estar em sequência lógica. Segundo Slunecko (2020):

Embora muitas vezes associado a computadores, algo tão simples como instruções sobre como montar um móvel é uma versão básica de um

\footnotetext{
${ }^{10}$ Levels of Development (LOD) ou Níveis de Desenvolvimento é uma métrica BIM para identificar quias informações incluir em um modelo durante o processo de projeto e construção (BIM DICTIONARY, 2020).

11 A série de documentos PAS 1192 define os requisitos para o nível de detalhes do modelo (o conteúdo gráfico), informações do modelo (conteúdo não gráfico, como dados de especificação), definição do modelo (seu significado) e trocas de informações do modelo (McPartland, 2017).
} 
algoritmo. Recebemos as peças necessárias para a montagem e conduzimos o processo passo a passo. Portanto, se seguirmos cada etapa com atenção, terminaremos com um móvel acabado, exatamente igual a todas as outras pessoas que compraram o mesmo produto e seguiram as instruções.

Se falamos de computadores, podemos definir nossos próprios algoritmos usando linguagens de programação, como Python, C ++, Java, ou podemos usar um software embebido como Grasshopper para Rhino ou Dynamo para Revit. A vantagem da última categoria é que eles são mais fáceis de usar e devem operar dentro do campo da geometria. Seu desenvolvimento permitiu que os arquitetos experimentassem a geração de formas, bem como automatizassem tarefas de mão de obra intensiva e possibilitassem a fabricação de estruturas complexas (SLUNECKO, 2020).

O autor demonstra, ainda, que é possível que o algoritmo receba mais do que 1 input, através do estabelecimento de relações entre instruções, que devem gerar outputs mais complexos, conforme ilustrado na Figura 10.

Figura 10 - Algoritmo simples e múltiplo

\section{DIAGRAM OF ALGORITHM WITH SINGLE INPUT}

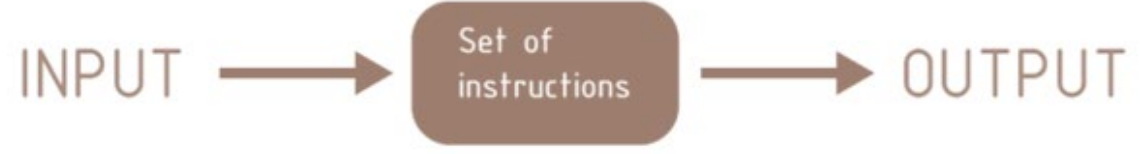

\section{DIAGRAM OF ALGORITHM WITH MULTIPLE INPUTS}

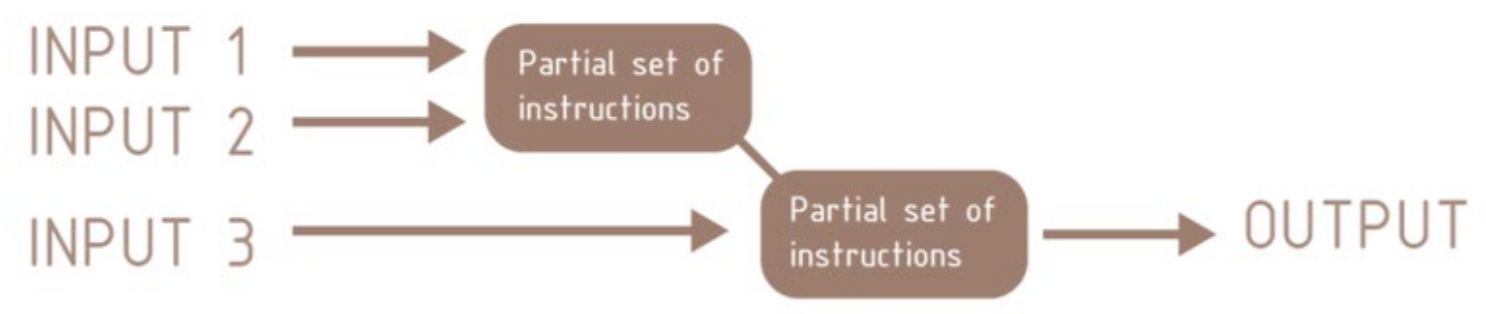

Fonte: Slunecko (2020).

As práticas de design auxiliado por algoritmos favorecem a exploração rápida de variações formais, uma vez elaborado o algoritmo e a partir de modificações de parâmetros e valores de variáveis (MINEIRO e MAGALHÃES, 
2019). Para Slunecko (2020) o AAD deve ser visto como um processo iterativo, no qual após se configurar as entradas e a definição das operações, deve se analisar o resultado, voltando a realizar alterações nas entradas ou no próprio resultado. $\mathrm{E}$ somente após uma certa quantidade de iterações, chega-se próximo a uma solução ótima. O processo de projeto definido por Slunecko é ilustrado na Figura 11.

Figura 11- Processo de projeto definido por Slunecko

\section{DESIRED FORM OF DESIGN PROCESS}

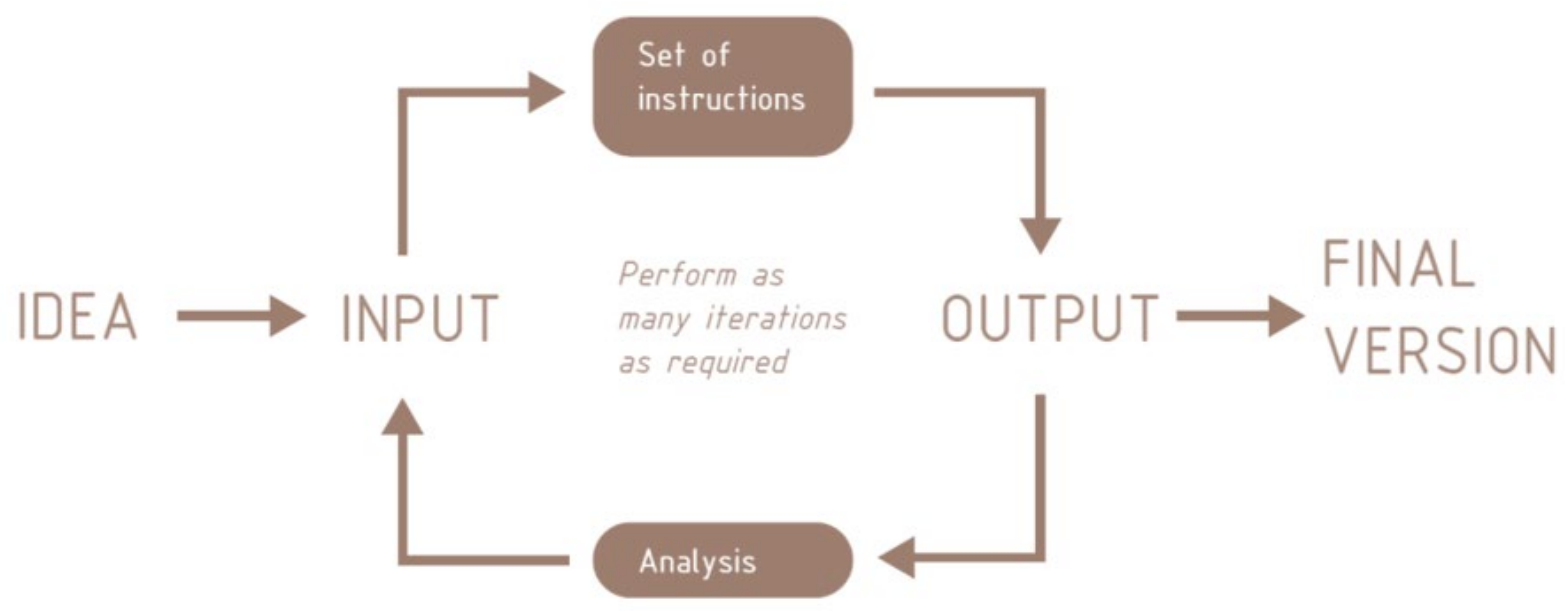

Fonte: Slunecko (2020).

Geralmente, ao pesquisar sobre projetos assistidos por algoritmos, é possível deparar-se com formas complexas, geometria abstrata e estruturas orgânicas. Entretanto, o AAD pode ser utilizado de forma mais pragmática, em tarefas variadas dentro do processo de projeto (SLUNECKO, 2020). As formas mais avançadas destas práticas são conhecidas como design paramétrico e design generativo (MINEIRO e MAGALHÃES, 2019).

Lipson e Kurman (2013) definem uma escala de sofisticação para diferentes modos de operar com formas tridimensionais em computadores. De acordo com essa escala, o modo mais simples de operar se dá pela definição da forma por notações fixas e produção de uma geometria estática. Em um segundo nível, programas de modelagem permitem aos usuários criar formas ajustáveis pela variação de parâmetros. No nível seguinte, estão os sistemas generativos, que se valem de metáforas e dinâmicas evolucionárias. Estes sistemas desenvolvem um 
corpo a partir de uma forma semente e de acordo com um conjunto de regras específicas.

Esclarecendo a questão entre as práticas e os modos operativos com sistemas CAD e AAD, Mineiro e Magalhães (2019) elaboraram uma tabela resumo (Quadro 5), que categoriza os tipos de abordagem para prática projetual auxiliada por computador e mediada por algoritmos.

Quadro 5 - Tipologia de projeto mediado por computadores e algoritmos

\begin{tabular}{|c|c|}
\hline Grupo & Categoria \\
\hline \multicolumn{2}{|r|}{ Modelagem por notações fixas } \\
\hline (Computer Aided Design) & $\begin{array}{l}\text { Sistemas paramétricos internos fechados com parâmetros } \\
\text { funcionais padronizados e pré-definidos }\end{array}$ \\
\hline \multirow{2}{*}{$\begin{array}{l}\text { Híbridos } \\
\text { CAD e AAD }\end{array}$} & $\begin{array}{l}\text { Sistemas CAD abertos para programação interna de funções } \\
\text { padrão pré-definidas (CAD com lógica AAD) }\end{array}$ \\
\hline & $\begin{array}{l}\text { Sistemas } A A D \text { com encadeamento simples de funções padrão pré- } \\
\text { definidas ( } A A D \text { com lógica } C A D)\end{array}$ \\
\hline \multirow{3}{*}{$\begin{array}{l}\text { AAD } \\
\text { (Algorithm Aided Design) }\end{array}$} & $\begin{array}{l}\text { Design paramétrico com encadeamento complexo de parâmetros } \\
\text { funcionais }\end{array}$ \\
\hline & $\begin{array}{l}\text { Design paramétrico com parâmetros particulares criados para um } \\
\text { projeto específico }\end{array}$ \\
\hline & Design generativo ou evolucionário \\
\hline
\end{tabular}

Fonte: Mineiro e Magalhães (2019).

Criar ou mesmo ajustar algoritmos generativos requer sólidos conhecimentos de matemática para que se possa efetivamente manipular a lógica de geração de modelos. No entanto as competências necessárias à criação de programas nem sempre é técnica ou científica. Caberia ao projetista, enquanto programador, o papel de codificar relações de projeto em um sistema técnico capaz de produzir variações em um espaço amplo, ainda que definido, de possibilidades de projeto (MINEIRO e MAGALHÃES, 2019). 
Há expectativas voltadas para práticas de design paramétrico baseadas no delineamento de redes de parâmetros e relacionamentos complexos capazes de considerar uma multiplicidade de aspectos relacionados aos artefatos, inclusive mercadológicos, culturais e de usabilidade. Práticas como estas poderiam incluir ainda aspectos tecnológicos embarcados e fabris, outros que impactam logística e distribuição e ainda, alcançar a criação de sistemas de customização em massa que considerem necessidades ou preferências individuais assegurando, ao mesmo tempo, a viabilidade produtiva e econômica (MINEIRO e MAGALHÃES, 2019).

Ao serem pensadas em contraposição aos processos convencionais de projeto, as práticas de design paramétrico e generativo se revelam modos particulares de explorar a complexidade, permitindo a experimentação com variações de parâmetros e de dinâmicas particulares, específicas e contextualizadas em cada projeto (MINEIRO e MAGALHÃES, 2019).

Para a construção da biblioteca de metacomponentes BIM, foi realizado um levantamento de bibliotecas BIM genéricas e públicas, com a finalidade de observar suas características, tipologias e estágios de desenvolvimento. Este estudo será apresentado no item 2.3.

\subsection{BIBLIOTECAS BIM}

A organização e classificação das informações de projeto são essenciais ao trabalho na metodologia BIM, destacando a importância de bibliotecas bem estruturadas que levem a economia, através da reutilização de informações e redução de retrabalho.

As bibliotecas BIM armazenam blocos básicos a partir dos quais os modelos BIM são construídos. Esses blocos representam todos os tipos de objetos que integram uma construção: vigas, pilares, lajes, pisos, paredes, forros, portas, janelas, tubos, conexões, dutos, mobiliário, equipamentos, etc (ABDI, 2017). Neste sentido, a biblioteca de componentes BIM para o Metrô/SP procura, através da compilação de elementos e sistemas construtivos, oferecer módulos macros das 
estações, com diversos componentes, a fim de facilitar o processo de projeto das estações.

O estudo das bibliotecas BIM é imprescindível para a estruturação de uma biblioteca de metacomponentes para as obras do Metrô/SP, que apresente qualidade e funcionalidade. $\mathrm{O}$ item 2.3 da pesquisa apresentará uma análise de duas bibliotecas BIM gerenciadas por órgãos públicos e duas bibliotecas mantidas por empresas privadas, listadas na Figura 12.

Figura 12 - Bibliotecas de componentes BIM analisadas

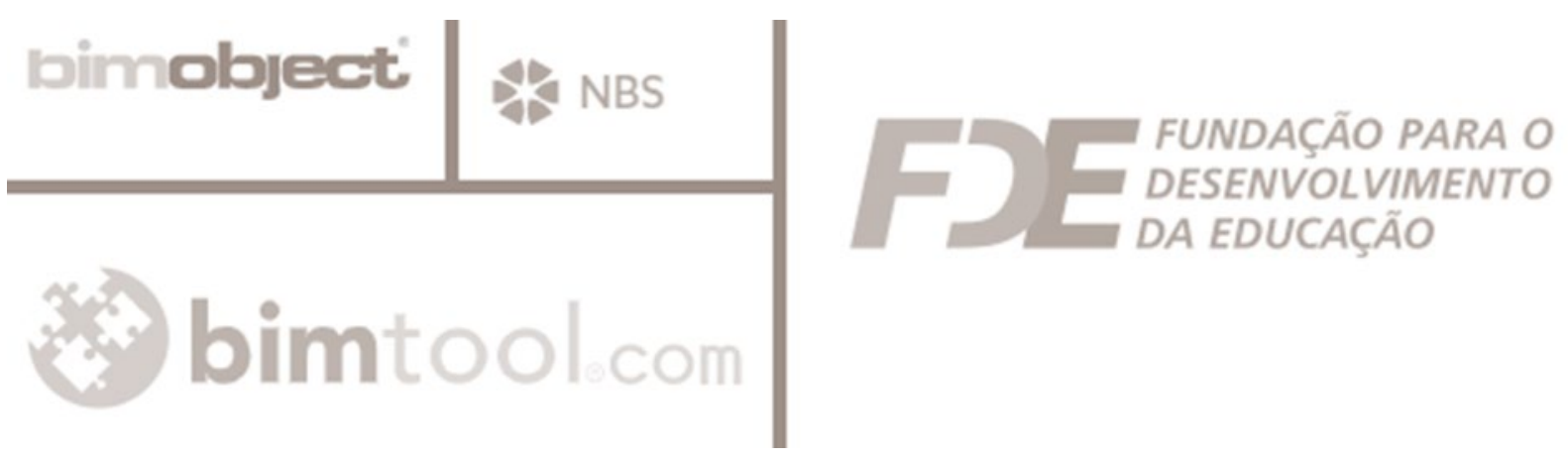

Fonte: Elaboração própria (2020).

As bibliotecas privadas analisadas foram eleitas por apresentarem características distintas quanto ao modo de criação e compartilhamento dos objetos, além de serem bibliotecas com utilização expressiva, a BIM Object é mantida por uma empresa europeia, e a BIM Tool é uma plataforma com origem na América do Sul. Quanto as bibliotecas públicas escolhidas para o estudo, a principal diferença entre elas é que a NBS disponibiliza componentes homologados de diversas áreas da construção civil, e a biblioteca da FDE é voltada para um nicho específico, o desenvolvimento de edifícios educacionais.

\subsubsection{BIM Object}

A BIM Object é uma biblioteca que incorporou o acervo da Autodesk Seek, criada pela empresa Autodesk com o objetivo de promover os objetos para o seu software BIM - Revit. Contudo, devido à necessidade de compatibilidade de objetos para outros softwares BIM, a plataforma foi vendida para a BIM Object, empresa sueca que difundiu os componentes e aumentou o acervo para diversas compatibilidades. A biblioteca é construída de modo compartilhado, o que quer dizer 
que qualquer usuário pode criar um objeto e publicá-lo na página (BIM OBJECT, 2019).

Com uma interface instintiva, clara e com ícones representativos, a BIM Object possui mais de 2 milhões de usuários cadastrados e são realizados, anualmente, mais de 25 milhões de downloads de objetos (BIM OBJECT, 2021). A BIM Object apresenta mais de 2 mil marcas diferentes para o download - apesar de nem todos os objetos serem paramétricos, a quantidade de componentes deste tipo é expressiva. Existem empresas fabricantes de componentes construtivos que disponibilizam as versões digitais dos seus produtos nesta biblioteca, dentre esses fabricantes, pode-se citar a Saint-Globain, Schneider, Roca, Celite, ArcelorMittal, Bosch e Kingspan.

Entre os objetos disponíveis, estão: objetos construtivos, de cozinha, eletrônicos, de engenharia e infraestrutura, equipamentos de carga, de esporte e lazer, de hidráulica, hospitalar, de iluminação, instalações elétricas, instalações sanitárias, janelas, materiais de construção, mobiliário, portas, entre outros. A BIM Object disponibiliza seus objetos em mais de 20 formatos distintos, de modo abrangente - atendendo às necessidades dos mais variados tipos de usuários. A Figura 13 apresenta uma captura da tela principal da biblioteca em questão.

Figura 13 - Página de busca por produtos, com detalhe para os filtros disponíveis

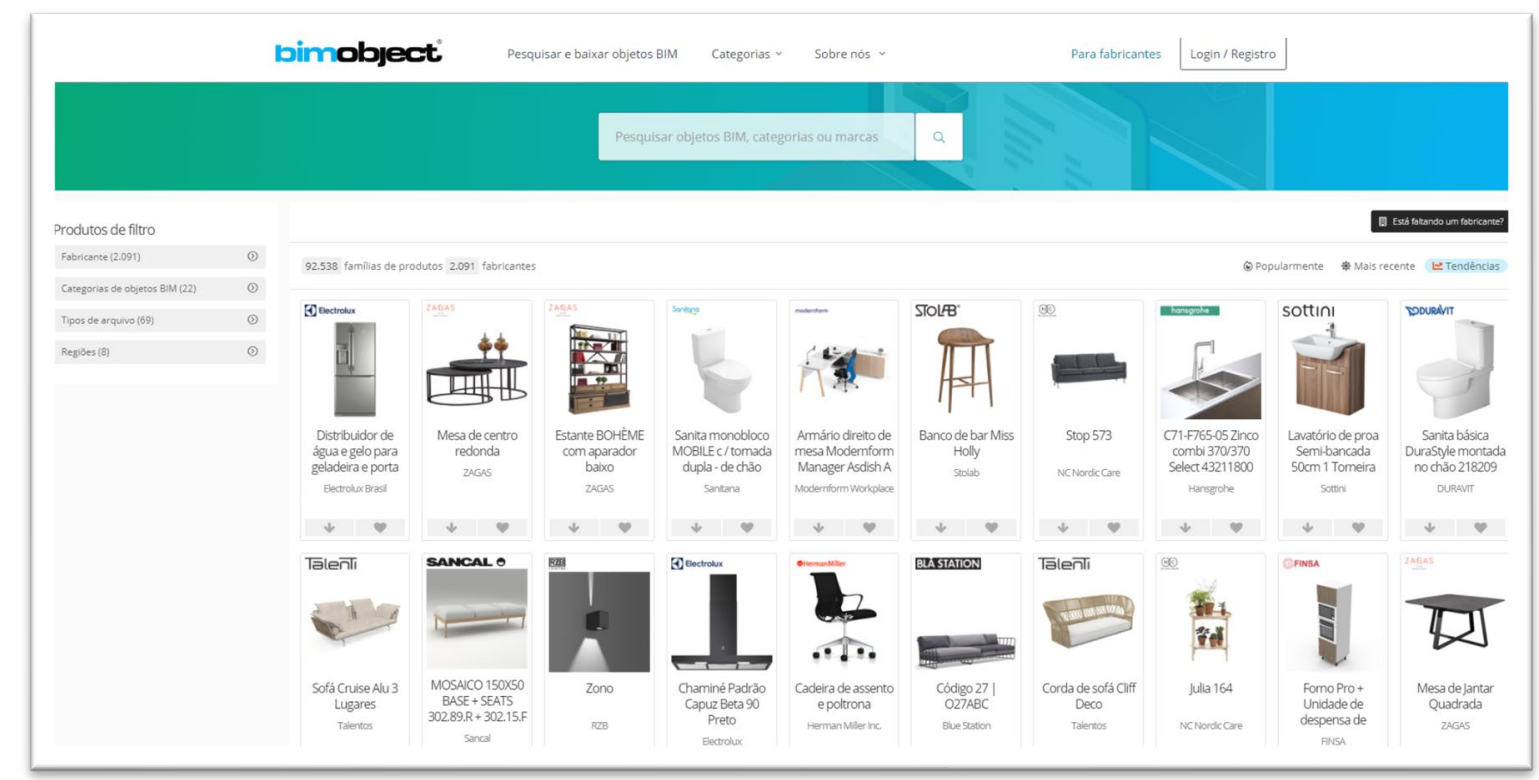

Fonte: BIM Object (2021). 
Basicamente, como a maioria das plataformas de bibliotecas BIM gratuitas, o seu funcionamento é baseado no compartilhamento dos objetos entre os usuários. Para que os interessados sejam capazes de baixar os arquivos da plataforma eles devem se cadastrar. Embora seja muito utilizada, a BIM Object não possui um certificado próprio. Ou seja, não existem critérios pré-estabelecidos aos quais as produções dos usuários tenham que cumprir para que essas possam ser compartilhadas no site. Por um lado, a falta de uma certificação é uma deficiência da plataforma, na medida em que sem um controle os objetos BIM compartilhados podem ser de má qualidade, mal dimensionados, e podem não respeitar às normas técnicas específicas de cada país. Por outro lado, como qualquer usuário pode compartilhar sua produção, o conhecimento do BIM passa a ser mais difundido, democratizado e acessível às pessoas.

\subsubsection{BIM Tool}

A BIM Tool é uma plataforma chilena que além de ser uma biblioteca de componentes, também oferece um espaço para o aprendizado e compartilhamento de conteúdos relacionados ao BIM. Uma das primeiras bibliotecas de componentes BIM da América do Sul, tem como objetivo o atendimento da comunidade AEC (Arquitetura, Engenharia e Construção) regional, o fomento de eventos que promovam o BIM e o estabelecimento de parcerias com organizações de países vizinhos (BIM TOOL, 2019).

A BIM Tool declara em seu site que até 2021 foram feitos 1.146 .749 downloads, 5.160 .394 visitas e 73.538 registros de usuários. O repositório conta com 50 marcas e 8.893 produtos. De acordo com a BIM Tool (2021), a categoria que mais teve itens baixados foi equipamentos, com cerca de $55,8 \%$ do volume enquanto o restante está concentrado em materiais de construção (22\%), outros $(9,1 \%)$, componentes de obra $(4,5 \%)$, paisagismo $(4 \%)$, instalações $(2,3 \%)$, escadas $(1,3 \%)$ e objetos de segurança $(1,1 \%)$.

A biblioteca, disponível em espanhol, possibilita a busca pelos componentes BIM em função da marca, especialidade, categoria e subcategoria, além da denominação do objeto. Nesse sentido, existem muitas categorias 
disponíveis que provém elementos para todas as áreas das diversas construções possíveis, das quais pode-se elencar: fachadas, exterior, interior, mobiliário, muros, pilares, pinturas, pisos, portas, sanitários, rampas, equipamentos MEP, urbanismo, entre outras opções. A Figura 14 apresenta a interface da plataforma, na página de busca por produtos.

Figura 14 - Página de busca por produtos da BIM Tool

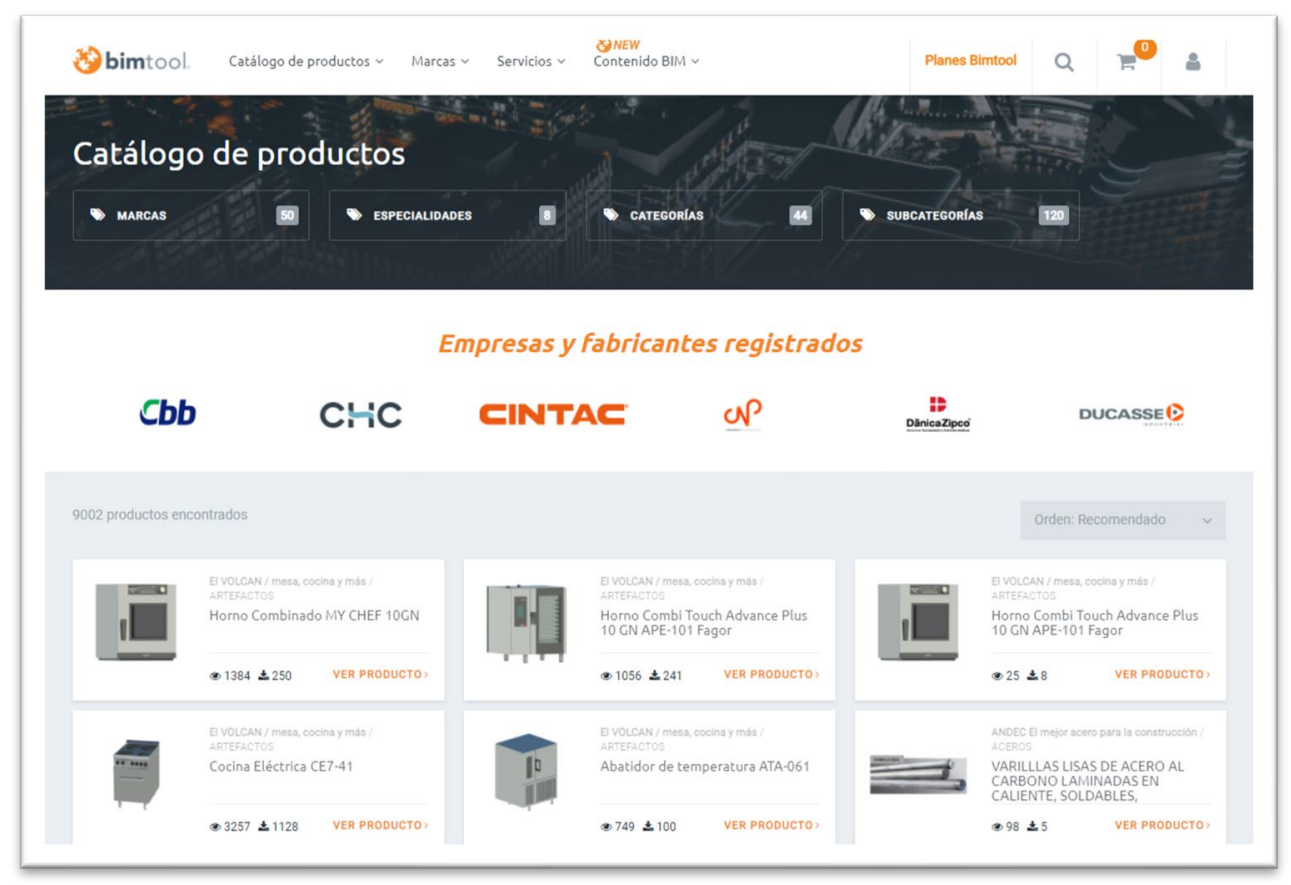

Fonte: BIM Tool (2021).

A BIM Tool não é completamente compartilhada. Qualquer usuário que se cadastre pode realizar o download dos produtos disponíveis de forma gratuita, contudo, para que um usuário ou empresa possa alocar seus objetos no site, é necessária a assinatura de um plano pago. Assim, o funcionamento da plataforma baseia-se na dinâmica em que uma marca ou fabricante paga o plano e disponibiliza seus produtos ou serviços, enquanto os usuários comuns apenas utilizam os arquivos. Dentre as marcas disponíveis no site, destacam-se: Gerdau, Hunter Douglas, Trespa, Kohler, Metalcon e Roca.

A variedade de formatos dos objetos é um fator importante para a difusão do Building Information Modeling. Isso porque atualmente existem diferentes softwares BIM no mercado - logo, existem diversos perfis de usuários, que usam programas diferentes. E a questão não se restringe a apenas apresentar os 
componentes em diversas formas, mas é necessário que os formatos sejam compatíveis entre si e que a conversão de um modelo para o outro não prejudique a qualidade do produto. $\mathrm{Na}$ BIM Tool, os formatos disponíveis são aqueles compatíveis com os softwares REVIT, Archicad, SketchUp e AutoCAD e ainda os formatos IFC, DXF e PDF.

\subsubsection{NBS National Library}

A biblioteca NBS é original do Reino Unido e pertence ao Royal Institute of British Architects (RIBA). De acordo com o site da biblioteca (Riba Enterprises, NBS, 2019) todos os objetos atendem aos requisitos do NBS BIM Object Standard, padrão reconhecido internacionalmente, que define requisitos de informações, geometria, comportamento e apresentação de objetos BIM.

A qualidade certificada é a principal vantagem dos objetos BIM dessa plataforma, garantindo segurança e trabalhabilidade aos usuários. O padrão NBS estabelece que todos os objetos adotem uma abordagem consistente para a classificação, apliquem uma convenção de nomenclatura padrão para facilitar o uso e padronizem abordagens para o nível de informação e apresentação dos objetos.

Segundo o site, a NBS preza por uma abordagem consistente de classificação que segue a nova norma internacional ISO 19650, complementada pela ISO 12006-2 (NBS,2019). Dentre esses objetos certificados, existem portas, sistemas de pavimentação, acessórios eletrônicos, isolamentos, calhas, revestimentos, telhados, painéis, acessórios sanitários, paredes, escadas, janelas, mobiliário, instalações e outros, como mostra a Figura 15. 
Figura 15 - Página de busca por produtos, com detalhe das categorias

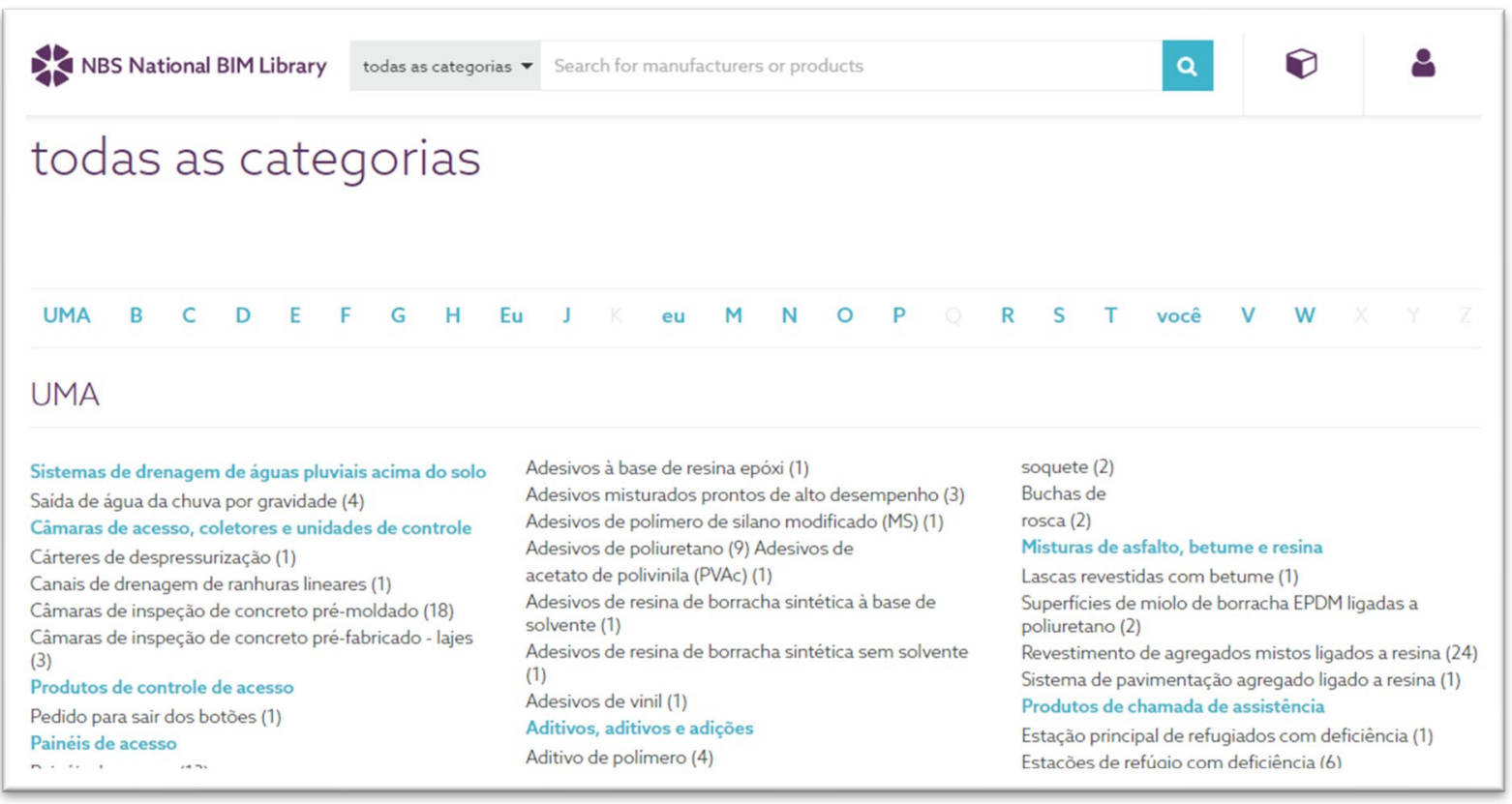

Fonte: NBS (2019).

O funcionamento da NBS é feito por meio do compartilhamento dos objetos entre os usuários. Diferentemente da BIM Object, essa biblioteca permite apenas que os objetos criados pelos usuários sejam alocados na plataforma depois que forem avaliados segundo o padrão NBS (National BIM Library). Isto quer dizer que apenas as produções que atendam aos requisitos do International BIM Object Standard são hospedadas na plataforma. Para que seja possível baixar os arquivos, basta se cadastrar. $\mathrm{O}$ cadastro para as pessoas interessadas apenas no download é bastante simples e rápido.

A plataforma também apresenta alguns objetos produzidos por empresas. Entre os principais produtores de objetos BIM que estão cadastrados na plataforma, pode-se citar: Mitsubishi Electric UK, Trovex Innovations, Movins Designs, Caesarstone UK, Premier Loft Ladders, Quantum Flooring. Em maioria, trata-se de fabricantes do Reino Unido. A NBS também procura viabilizar a difusão do BIM e, por isso, os objetos são disponibilizados em formatos compatíveis com os seguintes softwares: REVIT, ArchiCAD, Vector Works, AECOsim e IFC.

Outro serviço prestado pela NBS National Library é um relatório anual sobre o uso do BIM no país. O National BIM Report constatou, através de uma pesquisa realizada em 2018 (Figura 16), que a maior parte dos seus entrevistados 
(65\%) obtém objetos BIM criando-os internamente nos escritórios e depois os reutilizando. Esse dado leva a reflexão sobre a criação interna de objetos (desconsiderando os que representam itens sob medida ou específicos do projeto) que pode ser ineficiente, à medida que diversos projetistas criam o mesmo objeto, que quando reutilizado pode carregar informações desatualizadas ou imprecisas (NBS, 2018).

Figura 16 - Aquisição de objetos BIM

Where do you get the BIM objects your organisation uses?

\begin{tabular}{|c|c|c|c|c|c|c|c|c|c|c|c|}
\hline \multicolumn{2}{|r|}{$0 \%$} & $10 \%$ & $20 \%$ & $30 \%$ & $40 \%$ & $50 \%$ & $60 \%$ & $70 \%$ & $80 \%$ & $90 \%$ & $100 \%$ \\
\hline They are created in-house & $65 \%$ & & & & & & & & & & \\
\hline & & & & & & & & & & & \\
\hline They are created as needed & $59 \%$ & & & & & & & & & & \\
\hline for a project & & & & & & & & & & & \\
\hline Manufacturers provide them & $58 \%$ & & & & & & & & & & \\
\hline for us to use & & & & & & & & & & & \\
\hline We maintain our & $51 \%$ & & & & & & & & & & \\
\hline $\begin{array}{l}\text { own in-house library } \\
\text { of BIM objects }\end{array}$ & & & & & & & & & & & \\
\hline They are included in our & $50 \%$ & & & & & & & & & & \\
\hline CAD package & & & & & & & & & & & \\
\hline We use generic BIM objects & $45 \%$ & & & & & & & & & & \\
\hline We use the NBS National & $44 \%$ & & & & & & & & & & \\
\hline BIM Library & & & & & & & & & & & \\
\hline We use another BIM Library & $28 \%$ & & & & & & & & & & \\
\hline $\begin{array}{l}\text { We buy them from } \\
\text { specialists outside our } \\
\text { organisation }\end{array}$ & $9 \%$ & & & & & & & & & & \\
\hline
\end{tabular}

Fonte: NBS (2018).

\subsubsection{Biblioteca da FDE}

Criada em 1987, a Fundação para o Desenvolvimento da Educação (FDE) é uma entidade responsável por executar as políticas definidas pela Secretaria de Educação do Estado de São Paulo. Além de gerenciar os projetos destinados à Rede Estadual de Ensino, cabe à FDE - em conjunto com a Diretoria de Obras e 
Serviços - a construção e manutenção de mais de 5.000 escolas estaduais de ensino fundamental e médio no Estado de São Paulo (FDE, 2019).

O modelo de produção dos edifícios escolares gerenciados pela FDE segue uma sistematização caracterizada pela existência de componentes e serviços padronizados. Além disso, por atender à Secretaria Estadual, as contratações da FDE também devem ocorrer através de licitações. As semelhanças entre o processo de contratação e padronização das construções do Metrô/SP e da FDE justificam o estudo da biblioteca de componentes BIM desta fundação educacional.

Em 2013, a FDE iniciou um projeto de implantação gradativa do BIM em seus projetos, com o objetivo de tornar os processos de projeto, construção, reforma, restauro e ampliação das escolas mais eficientes, produtivos e transparentes, atendendo a uma demanda pública muito importante - além de permitir que os gestores da construção possuam maior controle e precisão das fases dos projetos e ao longo de suas vidas úteis. A implantação ocorreu com a modelagem de duas escolas que serviram como pilotos, após o planejamento, 0 estudo de viabilidade e a capacitação dos empregados da FDE, que ocorria desde 2011 (FDE, 2016b).

A página da fundação abriga as famílias de componentes, mobiliários e catálogos próprios, além de templates para as disciplinas de arquitetura, instalações hidráulicas e elétricas - abrangendo configurações, padronização de folhas, famílias anotativas, tags, modelos de vistas, tabelas e demais recursos que atendem ao padrão da FDE - e manuais técnicos contendo as diretrizes para a elaboração dos projetos em BIM. Porém a fundação não disponibiliza modelos completos com partes de edificações, como é proposto na pesquisa.

Todos esses itens desenvolvidos levam em consideração os aspectos relacionados às fases de projeto, os prazos, às atividades, aos fluxos e aos entregáveis - de modo a assegurar a viabilidade do projeto de implantação. Um fato importante é que a entidade implementou o BIM de modo que todos os seus componentes seguissem as premissas de "aderência à padronização e aos métodos já estabelecidos na FDE, bem como a compatibilidade na extração de quantitativos com as regras de listagem de preços" (FDE, 2016c). 
De acordo com o site da fundação, para a implantação do BIM na FDE foram necessários dois anos de desenvolvimento, totalizando 4700 horas de trabalho na discussão dos usos, padrões e processos. Cerca de $13 \%$ do tempo foi direcionado à realização de reuniões técnicas, 32\% dos destinado à modelagem dos dois primeiros projetos pilotos, $33 \%$ foi utilizado para a confecção de templates, $6 \%$ para a modelagem de mobiliário e $15 \%$ para a capacitação e confecção dos manuais internos e de uso público (FDE, 2016a).

Para acessar os objetos BIM desenvolvidos pela FDE, basta realizar um cadastro como estudante ou profissional na página da fundação. Depois da última atualização em julho de 2019, o site apresentava diversas famílias, divididas nas categorias: abrigos, acessibilidade, coberturas, corrimão, cubas, elétrica, esquadrias, estrutura, fechamentos de divisas, forros, fossas, hidráulica, hidrossanitário, luminárias, mobiliário, mobiliário externo, pisos, portões, quadras, reservatórios de concreto, reservatórios metálicos, sinalização, vedos, revestimentos e pinturas. Ou seja, diferentemente das outras bibliotecas genéricas que contém diversos objetos confeccionados por vários produtores distintos e sem uma finalidade comum para todos os componentes, a biblioteca da FDE apresenta categorias pensadas para cada parte do projeto de construção, reforma ou ampliação de uma escola.

Vale salientar que não é possível visualizar nenhuma imagem dos componentes através do site, pois, todos os arquivos encontram-se em pastas compactadas - ou seja, o usuário só pode ver o produto se baixá-lo primeiro. $\mathrm{Na}$ página, apenas existem as listas com as categorias, o status de revisão, a data de atualização e a de implantação.

A biblioteca da FDE, diferente das outras bibliotecas estudadas até aqui, não é uma plataforma compartilhada, ou mesmo efetuada para a venda como um serviço. O funcionamento da biblioteca é fomentado pela FDE, que é responsável em conjunto com outros atores - pelo desenvolvimento, atualização e pela disponibilização dos arquivos ao público. Trata-se, portanto, de um compilado que tem um objetivo específico - o de fornecer insumos aos estudantes e profissionais para os projetos das escolas.

O uso da metodologia BIM torna fácil e rápido o processo de comparação de soluções de projeto, na medida em que o arquiteto, engenheiro ou técnico pode 
experimentar no modelo, de forma que cada modificação altera simultaneamente os quantitativos. Assim, os profissionais podem decidir, por meio desses números, o custo-benefício e a consequência daquela alteração, garantindo a melhor decisão. Verifica-se, então, que essa área de quantitativos e orçamentos possui um grande potencial de utilização para a FDE, que trata de muitos empreendimentos ao mesmo tempo. Os softwares BIM permitem o estudo de custos de acordo com o modo operacional da FDE, de maneira rápida, segura e conectada (ESTEVES, 2016). A Figura 17 exemplifica uma tabela de quantitativos da FDE.

Figura 17 - Tabela de quantitativos de algumas quadras da família da FDE

\begin{tabular}{|c|c|c|c|c|}
\hline A & B & C & $\mathrm{D}$ & $\mathrm{E}$ \\
\hline Nota-chave & Descrição & Código de listagem & Área & Count \\
\hline QE-02 & Poste para rede de voleibol - fundação direta (descoberta) & 16.04 .001 & & 3 \\
\hline QE-03 & Trave de futebol de salão - fundação direta (descoberta) & 16.04 .002 & & 6 \\
\hline QE-12 & Quadra de esportes / piso de concreto armado / fundação direta $600 \mathrm{~m}^{2}$ (descoberta) & 16.04 .007 & $600.00 \mathrm{~m}^{2}$ & 2 \\
\hline QE-23 & Espaço multiesportivo / piso de concreto armado / fundação direta $160 \mathrm{~m}^{2}$ (descoberto) & 16.04 .043 & $160.00 \mathrm{~m}^{2}$ & 1 \\
\hline QE-26 & Quadra de esportes / piso de concreto / laje alveolar (com pintura) & 13.02 .010 & $600.00 \mathrm{~m}^{2}$ & 1 \\
\hline QE-27 & Quadra de esportes / piso de concreto / pré-laje treliçada (com pintura) & 13.02 .011 & $600.00 \mathrm{~m}^{2}$ & 1 \\
\hline QE-28 & Quadra de esportes / piso com proteção acústica sobre laje (com pintura) & 13.02 .012 & $600.00 \mathrm{~m}^{2}$ & 4 \\
\hline
\end{tabular}

Fonte: FDE (2019).

Uma questão trazida por Esteves (2016) é a interoperabilidade entre softwares. Trata-se de um desafio enorme, mas que deve ser trabalhado para que os componentes sejam acessíveis a um maior número de pessoas, e, mais do que isso, para que os componentes sejam usados em cada programa específico, de acordo com as necessidades de cada processo. Por exemplo, o mobiliário da biblioteca da FDE foi produzido no Autodesk INVENTOR, um aplicativo mecânico que traz muitos detalhes. Usá-lo nesse formato é bom para a produção industrial, que necessita deste detalhamento. Contudo, tantos detalhes mínimos não são necessários ao arquiteto. A interoperabilidade deve fazer com que o projetista use o mesmo mobiliário, em outro software, de acordo com aquilo que é importante ilustrar.

Na Figura 18, é apresentado um mobiliário modelado pela FDE, na visualização 3D - algo que antes não existia com tantos detalhes e funcionalidades na dinâmica tradicional de projetos. 
Figura 18 - Visualização 3D de mobiliário de sala modelados pela FDE

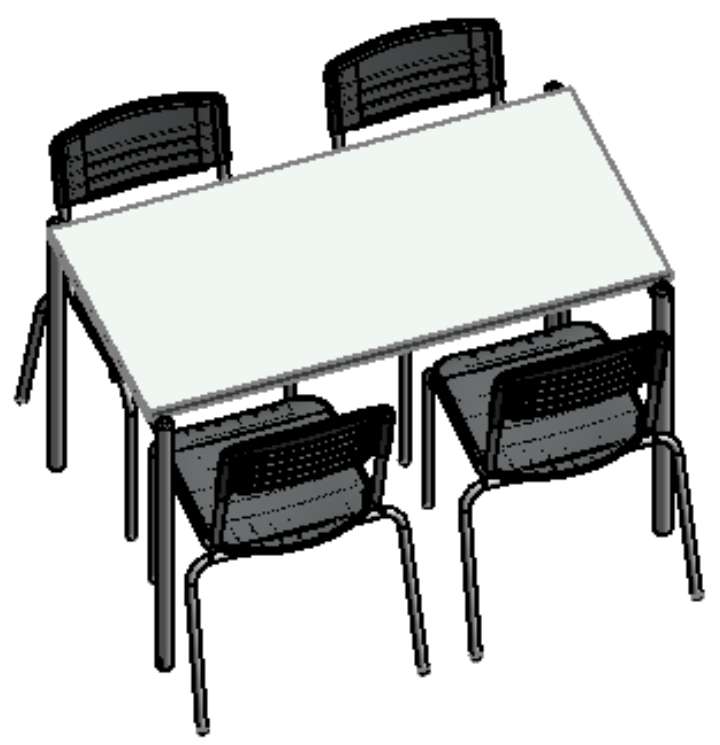

Fonte: FDE (2019).

A extração de informações do projeto se tornou algo mais fácil e eficiente, já que agora todos os projetos, sistemas, documentação, orçamentos e quantitativos estão no mesmo lugar. Isso dá maior controle e conhecimento sobre o produto, os custos e processos industriais.

A modelagem também influenciou na produtividade das obras. Atualmente, por meio da prototipagem e impressão 3D é possível produzir exatamente o componente parametrizado no software. Isso também possibilita a inovação na produção dos elementos construtivos, de forma que a fabricação destes se torne mais mecanizada, controlada e escalável (FDE, 2016b). A Figura 19 exemplifica uma peça modelada pela FDE e posteriormente impressa.

Os produtos BIM modelados foram confeccionados por meio de um esforço mútuo de várias partes interessadas, sobretudo os profissionais da FDE. De tempos em tempos, a FDE atualiza seus catálogos técnicos, templates, manuais e famílias, de modo a continuar entregando qualidade aos usuários dos produtos. A última atualização da FDE ocorreu em julho de 2020, conforme apresentado na Figura 20. 
Figura 19 - Impressão 3D de uma peça de um objeto da FDE, a partir do seu protótipo
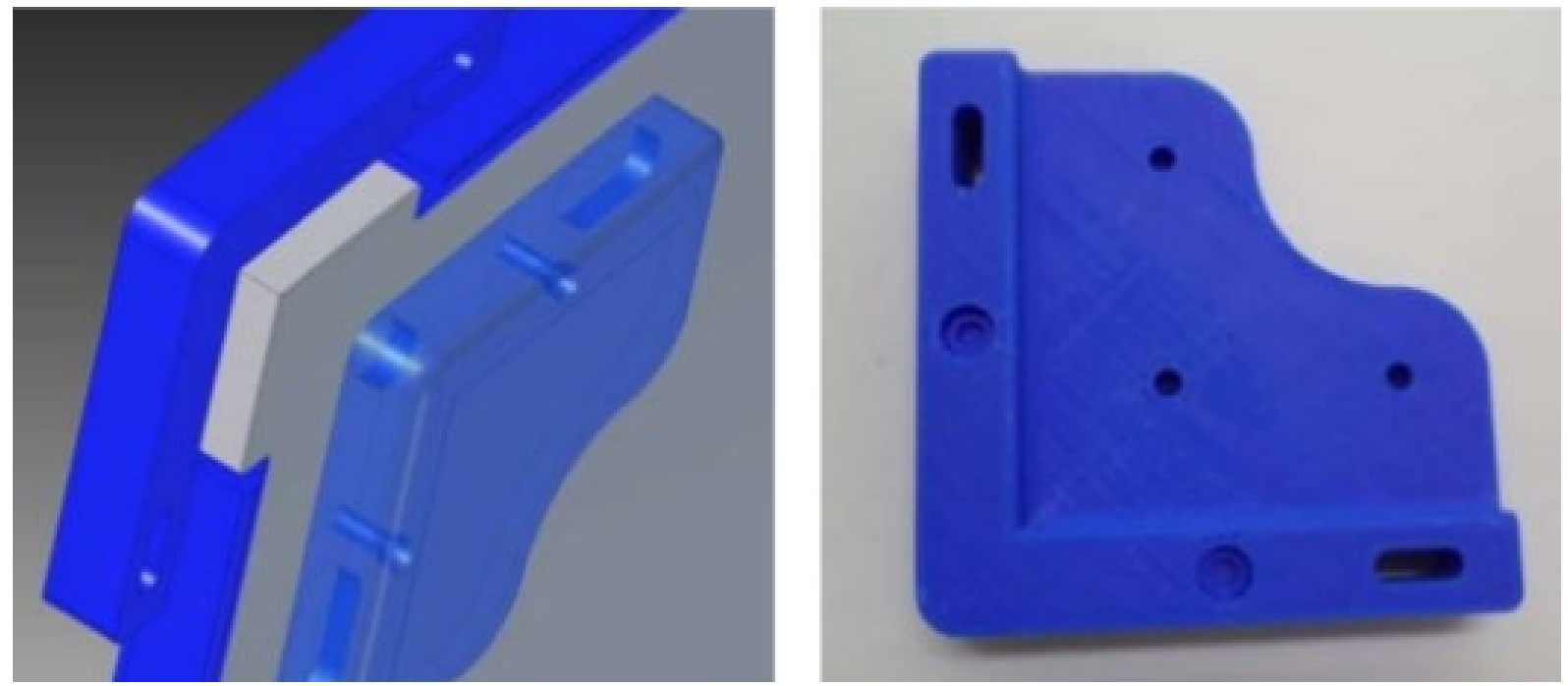

Fonte: FDE (2016b).

Figura 20 - Últimos catálogos técnicos da FDE atualizados

\section{Catâlogos técnicos}

\section{BIM - Building Information Modeling}

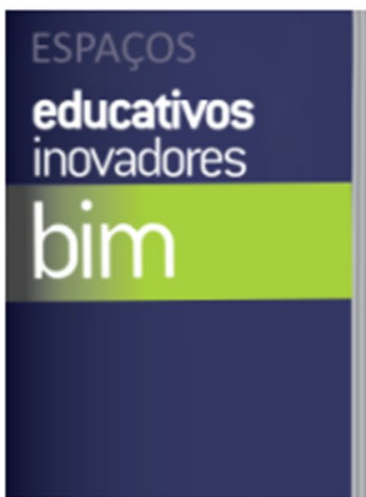

Julho / 2020

\section{Espaços}

Educativos

Espaços Educativos

Inovadores - Building

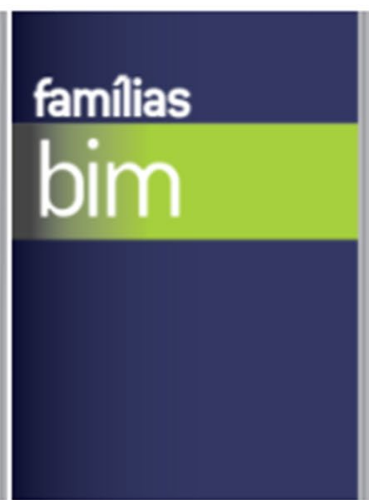

Julho / 2020

Famílias

Building Information

Modeling

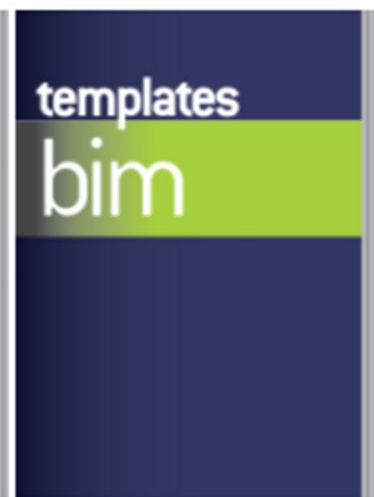

Julho / 2020 Templates

Building Information Modeling

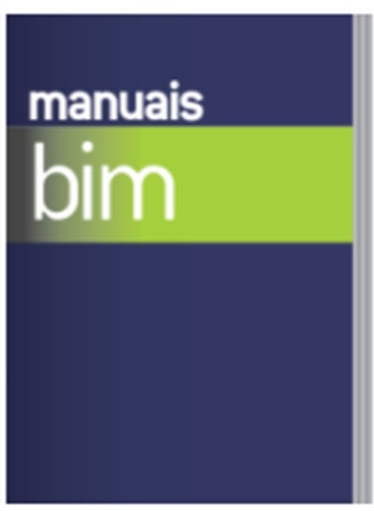

Julho / 2020

Manuais

Building Information Modeling

Fonte: FDE (2020). 
Até a última atualização, a biblioteca dos componentes da FDE apresentava objetos BIM compatíveis apenas com o software REVIT, de modo que os arquivos apresentavam as extensões .rvt, .rfa e .rte. De acordo com Relatório do Grupo de Trabalho Relativo à Tecnologia BIM (GT BIM) da FDE (2016b), a escolha da ferramenta baseia-se em uma pesquisa acerca das funcionalidades do programa e da sua adequação ao que é necessário nesse contexto dos projetos das escolas.

Verifica-se, portanto, que os componentes ficam limitados apenas ao uso dos usuários do REVIT, fato que tem sido discutido pela FDE. Em setembro de 2016, em uma reunião do GT BIM, foram tratadas as questões de interoperabilidade entre softwares, bem como os avanços e limitações do IFC. Nessa reunião, o diretor geral da GRAPHISOFT afirmou que a empresa propõe-se a transcrever os conteúdos da FDE já existentes para o formato do ARCHICAD - extensão .pln - mas as quantidades de informações a serem transpostas nesse primeiro experimento não foram definidas na reunião (FDE, 2016b).

Esse esforço é benéfico, se realizado com cautela e qualidade - já que para o uso em um formato adicional seja eficiente, é preciso que os componentes sejam transcritos corretamente, e que os dados sejam compatíveis aos componentes existentes. Além disso, ainda em setembro de 2016 , o diretor geral da GRAPHISOFT no Brasil se propôs a capacitar os técnicos da FDE a receber e trabalhar os arquivos em outros formatos, seja no formato nativo do ARCHICAD ou no formato aberto universal IFC (FDE, 2016b).

Os benefícios dessa tradução de qualidade são o aumento do alcance dos objetos - pois outros projetistas podem passar a utilizar os arquivos, que agora são compatíveis com outro software - e a garantia de que a FDE não está praticando reserva de mercado. Até março de 2021 , os arquivos transcritos ainda não estavam disponíveis para os usuários. 

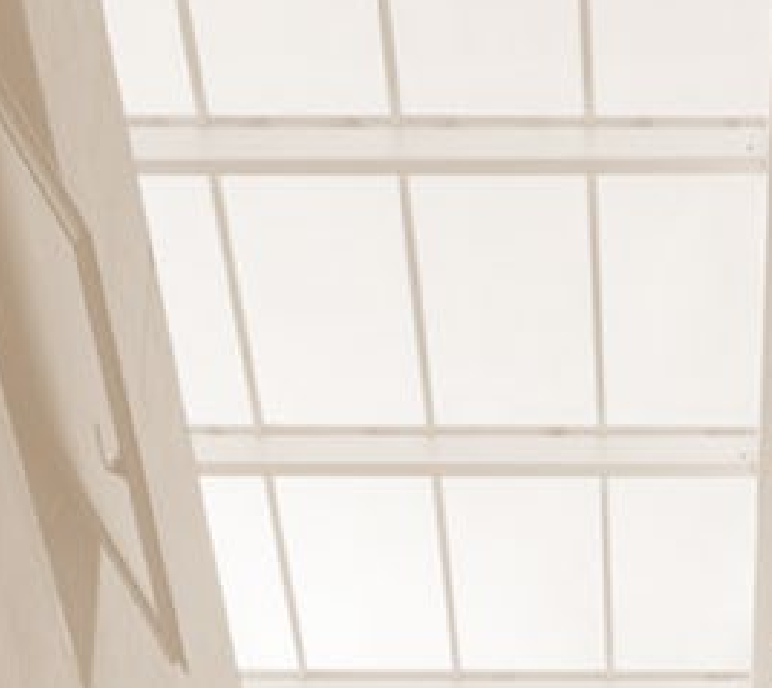

$1+2 \cdot x^{2}$

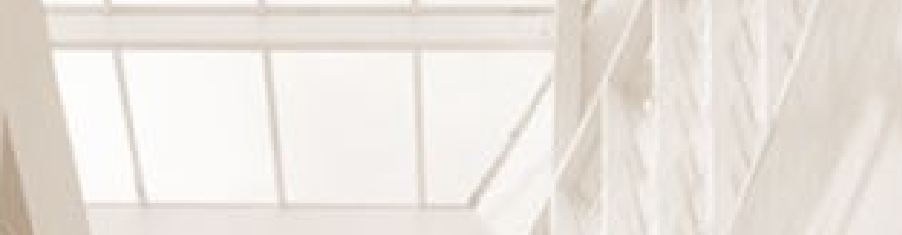

Estação Vila Prudente, São Paulo Fonte: Kon (2016). 
CAPÍTULO 3 | METRÔ DE SÃO PAULO 



\section{3 | METRÔ DE SÃO PAULO}

\subsection{CONSIDERAÇÕES INICIAIS}

Esse capítulo é destinado as informações coletadas sobre o Metrô/SP, tanto em relação ao processo de projeto na companhia, tanto quanto a padronização dos projetos executados pela mesma.

A Companhia do Metropolitano de São Paulo - Metrô/SP surgiu em 1968 e ao longo das últimas cinco décadas implantou seis linhas (1-Azul, 2-Verde, 3Vermelha, 4-Amarela, 5-Lilás e 15-Prata), com 101 quilômetros de trilhos e 89 estações na cidade de São Paulo (Relatório Integrado - CMSP, 2019b).

A rede metropolitana de transporte sobre trilhos é o elemento estruturador da mobilidade da Região Metropolitana de São Paulo - RMSP (CMSP, 2018a), reservando ao Estado as funções de concepção, planejamento e organização de um sistema de alta capacidade, abrangendo a implantação da rede metroviária e sua articulação com os demais modais de transporte em operação na cidade (CMSP, 2018b).

O Plano Integrado de Transportes Urbanos (PITU), desenvolvido em 2013 pela Secretaria de Transportes Urbanos, apresenta uma rede com 14 linhas de metrô, configurando uma rede estruturada com elementos radiais, e circulares. Esse planejamento propõe a expansão da rede metroviária da cidade de São Paulo em 8 novas linhas. Ressaltando a importância em agilizar o processo de concepção e contratação dessas obras.

De acordo com a metodologia de Gestão de Empreendimentos de Expansão do Metrô de São Paulo (2019a), a viabilização de um empreendimento na companhia tem 5 fases, conforme ilustra a Figura 21. 
Figura 21 - Fases do empreendimento no Metrô/SP

\begin{tabular}{|l|c|c|c|c|}
\hline FASE 1 & FASE 2 & FASE 3 & FASE 4 & FASE 5 \\
\hline Validação & Detalhamento & $\begin{array}{c}\text { Licitação e } \\
\text { obtenção de áreas }\end{array}$ & Implantação & Encerramento \\
\hline
\end{tabular}

Fonte: Relatório de empreendimentos - CMSP (2019b).

O tempo de desenvolvimento de cada fase depende de inúmeros fatores e, principalmente, de políticas públicas e investimentos do Estado. A crise econômica e os reflexos da operação Lava Jato, com denúncia das grandes construtoras ligadas a corrupção, causaram diversas paralisações e atrasos nas obras em andamento do Metrô de São Paulo. Em 2015, o Metrô/SP construía ou ampliava 7 linhas ao mesmo tempo, no entanto nenhuma das obras foi concluída dentro dos prazos estimados, conforme demonstra o comparativo da implantação de empreendimentos entre os anos de 2015 e 2021, apresentado no Quadro 6 (DANTAS, 2015 e CMSP, 2021).

Quadro 6 - Metrô/SP - Implantação dos empreendimentos: Comparativo entre os anos de 2015 e 2021

2015

2021

Linha 2-Verde

Vila Prudente a Dutra, com

13 estações $\mathrm{e}$

Vila Prudente a Penha, com 8

Trecho

prolongamento de $15,5 \mathrm{~km}$

estações e prolongamento de $8 \mathrm{~km}$

\begin{tabular}{lll}
\hline Status & Contrato assinado & Obras em andamento \\
\hline Assinatura do contrato & 2014 & \\
\hline Previsão & 2020 & 2026 \\
\hline
\end{tabular}

Investimento (apenas obras

civis)

$\mathrm{R} \$ 6,7 \mathrm{bi}$

$\mathrm{R} \$ 6$ bi 


\section{Linha 4-Amarela}

Vila Sônia a Butantã, com 4 estações e prolongamento

Trecho

\begin{tabular}{|c|c|c|}
\hline Status & $\begin{array}{l}\text { Obras paradas e em } \\
\text { renegociação }\end{array}$ & $\begin{array}{l}\text { Parcialmente inaugurada, com } \\
\text { obras em andamento }\end{array}$ \\
\hline Assinatura do contrato & 2009 & \\
\hline Previsão & 2016 & 2021 \\
\hline Investimento & $\mathrm{R} \$ 559$ milhões & - \\
\hline \multicolumn{3}{|c|}{ Linha 15 - Prata (Monotrilho) } \\
\hline \multirow[t]{2}{*}{ Trecho } & $\begin{array}{l}\text { Vila Prudente a Cidade } \\
\text { Tiradentes, com } 17 \text { estações } \\
\text { e prolongamento de } 24,5 \mathrm{~km}\end{array}$ & $\begin{array}{l}\text { Ipiranga a Jacu-Pêssego, com } 14 \\
\text { estações e prolongamento de } 19 \\
\text { km }\end{array}$ \\
\hline & $\begin{array}{l}\text { Linha pronta entre Vila } \\
\text { Prudente e São Mateus, mas } \\
\text { falta construir estações. }\end{array}$ & $\begin{array}{l}\text { Obras em andamento, nos trecho } \\
\text { de São Mateus a Jacu-Pêssego, e } \\
\text { Vila prudente a Ipiranga. }\end{array}$ \\
\hline Assinatura do contrato & 2010 & \\
\hline Previsão & 2016 & 2024 \\
\hline Investimento & $\mathrm{R} \$ 7,2 \mathrm{bi}$ & - \\
\hline Linha 17-Ouro (Monot & & \\
\hline
\end{tabular}

Luz a Vila Sônia (fase 2), com 11 estações e prolongamento de 12,8 $\mathrm{km}$ 


\begin{tabular}{|c|c|c|}
\hline Assinatura do contrato & 2011 & \\
\hline Previsão & 2016 & Em reprogramação \\
\hline Investimento & $\mathrm{R} \$ 5,1 \mathrm{bi}$ & - \\
\hline \multicolumn{3}{|l|}{ Linha 6-Laranja } \\
\hline \multirow[t]{2}{*}{ Trecho } & $\begin{array}{l}\text { Brasilândia a São Joaquim, } \\
\text { com } 15 \text { estações, e extensão } \\
\text { de } 15,9 \text { km }\end{array}$ & $\begin{array}{l}\text { Brasilândia a São Joaquim, 15,3 } \\
\text { km de extensão }\end{array}$ \\
\hline & & $\begin{array}{l}\text { Obras paralisadas desde } 2016 \text {, e } \\
\text { retomadas pela construtora }\end{array}$ \\
\hline Status & Obras em andamento & Acciona em 2020 \\
\hline Assinatura do contrato & 2013 & Novo contrato em 2020 \\
\hline Previsão & 2020 & 2025 \\
\hline Investimento & $\mathrm{R} \$ 9,6 \mathrm{bi}$ & $\mathrm{R} \$ 15 \mathrm{bi}$ \\
\hline Linha 5-Lilás & & \\
\hline
\end{tabular}

\begin{tabular}{lll}
\hline & $\begin{array}{l}\text { Adolfo Pinheiro a Chácara } \\
\text { Klabin, com 10 estações e } \\
\text { Trecho }\end{array}$ & $\begin{array}{l}\text { Adolfo Pinheiro a Campo Belo, com } \\
11 \text { estações }\end{array}$ \\
\hline Status & Obras em andamento $11,5 \mathrm{~km}$ & Concluído \\
\hline Assinatura do contrato & 2010 & Conclusão em 2019 \\
\hline Previsão & 2017 & $\mathrm{R} \$ 9,4$ bi \\
\hline Investimento & $\mathrm{R} \$ 8,9 \mathrm{bi}$ &
\end{tabular}

\section{Linha 18-Bronze (Monotrilho)}

Trecho

Tamanduateí a Djalma

Dutra, com 13 estações e 
2015

2021

$15,7 \mathrm{~km}$

Contrato assinado

Projeto cancelado

Status Contrato assinado Projeto cancelado

Assinatura do contrato

2014

2018

Investimento

$\mathrm{R} \$ 4,2$ bi

Linha 19-Celeste

Trecho Anhangabaú a Bosque

Trecho

Maia (Guarulhos)

Status

Em estudo

\section{Linha 20-Rosa}

Trecho

Santa Marina a Santo André

Status

Em estudo

Fonte: Elaboração própria, com base em DANTAS (2015) e CMSP (2021).

O tempo de concepção das linhas e de desenvolvimento dos projetos básicos, ou licitatórios, é longo. Um exemplo é apresentado na Figura 22, que mostra uma linha do tempo, desde a finalização do relatório técnico, com a concepção da extensão da Linha 2-Verde, até a conclusão do projeto básico de uma das estações previstas. 
Figura 22 - Processo de concepção e contratação da estação Ponte Grande

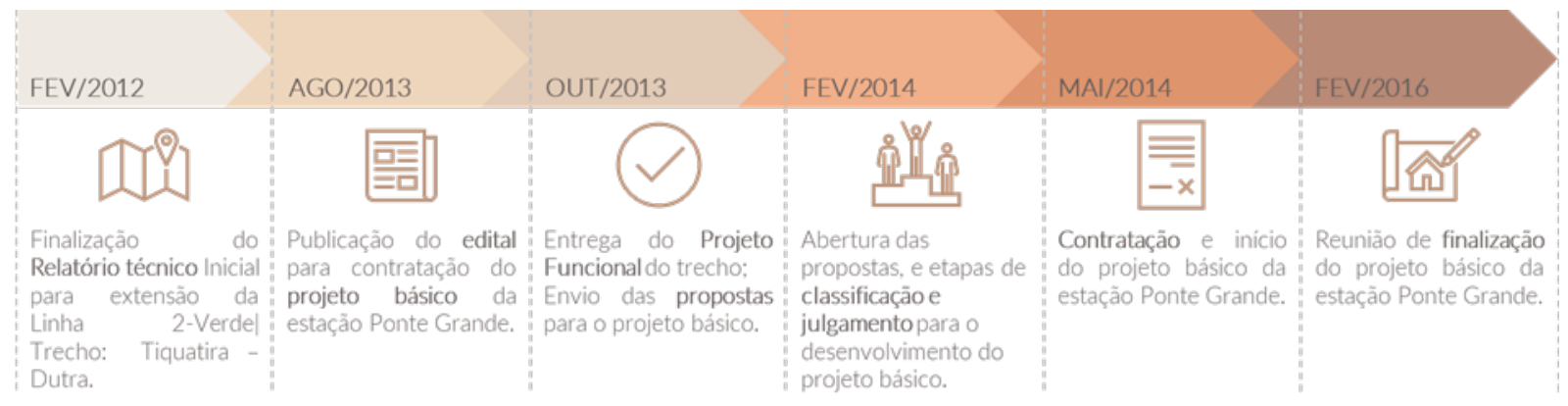

Fonte: Elaboração própria (2020)

A fase inicial de projeto, compreendendo os estudos preliminares e o projeto básico, é essencial para o processo licitatório, assim como para o bom andamento e execução da obra. O item 3.2 da pesquisa irá explorar o processo de concepção das estações metroviárias, afim de analisar de que forma a biblioteca de metacomponentes BIM, objeto do estudo, pode otimizar o processo de projeto de estações de metrô.

\subsection{PROCESSO DE PROJETO NO METRÔ DE SÃO PAULO}

As diretrizes de concepção das estações do Metrô/SP foram estabelecidas pelo arquiteto Marcello Fragelli, na década de 60, para a construção da primeira linha de metrô no Brasil, a Linha Norte Sul - atual Linha 1-Azul. A partir destas diretrizes moldou-se o processo que, ainda hoje, orienta o exercício de projeto das instalações metroviárias na companhia (CMSP, 2019b).

O desenvolvimento dos projetos na Companhia do Metropolitano de São Paulo é estruturado em diversas etapas, e realizado por diferentes departamentos e/ou empresas contratadas. Segundo a instrução de projeto IP-9-000000/3A0-001 (2010), que trata das diretrizes para a elaboração de documentação técnica, as etapas de projeto no Metrô/SP, em geral, são: projeto funcional, projeto básico, projeto executivo, projeto com finalidades de manutenção e projeto com finalidade de operação. E as disciplinas envolvidas nos projetos de edificações metroviárias são: engenharia civil, arquitetura, geotecnia, topografia, desapropriações. 
O presente trabalho irá descrever sobre o processo de desenvolvimento das estações nas etapas de projeto funcional e básico, que são as fases responsáveis por fornecer subsídios às licitações. A pesquisa se concentra nestas etapas de projeto, com o objetivo de compreender o processo, para adequá-lo a uma nova metodologia, e para averiguar quais as informações e procedimentos são importantes para o desenvolvimento da biblioteca de metacomponentes BIM.

\subsubsection{Projeto Funcional}

O projeto funcional é a primeira fase para implantação de uma nova linha de metrô. Nesta etapa são definidas as questões principais, como: o traçado da linha, a localização de suas estações, dos terminais de integração, dos pátios de manutenção e de estacionamento de trens. Estudos complexos de planejamento analisam as consequências da implantação de uma linha, através dos seus impactos: no transporte público, no uso e ocupação do solo, no meio ambiente e na infraestrutura urbana.

A elaboração do Projeto Funcional pressupõe a realização de estudos de (CMSP, 2016):

a) caracterização regional;

b) reorganização de transportes coletivos;

c) estimativa de demanda ${ }^{12}$;

d) alternativas e definição de traçado;

e) detalhamento da alternativa de traçado recomendado;

f) estudos preliminares que definam os elementos necessários e suficientes para o desenvolvimento do projeto básico.

A pesquisa de Origem e Destinos - O/D fornece os diagnósticos, parâmetros e indicadores necessários à definição da expansão da rede metropolitana. Estas pesquisas são decenais e realizadas desde a criação do Metrô de São Paulo, com sua última versão concluída em 2017. Os dados levantados

\footnotetext{
${ }^{12}$ Quantidade de usuários da estação ou do sistema durante um determinado período de tempo (NBR 16.702).
} 
alimentam os modelos de simulação de demanda, orientando os estudos de viabilidade econômico-financeira e o detalhamento de novas configurações da malha de transporte sobre trilhos e de sua articulação com os demais modos (CMSP, 2018).

A determinação da distribuição da demanda de viagens é fator decisivo para: o cálculo do carregamento das linhas de metrô, o dimensionamento das estações e equipamentos ligados ao fluxo de passageiros (escadas rolantes, acessos, bloqueios, etc.), o dimensionamento do quadro de pessoal das estações e principalmente, para o dimensionamento da oferta de trens colocada em operação (SANTOS, 1997).

A demanda estimada de cada estação irá balizar o dimensionamento do projeto para que se evite atingir taxas altas em relação ao nível de conforto, acima de 5 passageiros $/ \mathrm{m}^{2}$. De acordo com Santos (1997), os padrões técnicos de nível de conforto utilizados pelo Metrô/SP se baseiam no trabalho intitulado "Pedestrian Planning and Desing" de Jonh J. Fruin. Este estudo estabelece seis níveis de conforto em função da área disponível por indivíduo, a Tabela 2 apresenta os resultados do trabalho.

Tabela 2 - Nível de conforto $\left(\mathrm{m}^{2} /\right.$ pessoa)

\begin{tabular}{|c|c|c|c|}
\hline NíVEL DE CONFORTO & $\mathrm{m} 2$ / pessoa & pessoas / $\mathrm{m} 2$ & Fatores Psicológicos \\
\hline A & mais de 1,2 & menos de 0,8 & nenhum \\
\hline B & de 1,2 a 0,9 & de 0,8 a 1,1 & nenhum \\
\hline C & de 0,9 a 0,7 & de 1,1 a 1,4 & zona de conforto \\
\hline D & de 0,7 a 0,3 & de 1,4 a 3,3 & contato evitável \\
\hline E & de 0,3 a 0,2 & de 3,3 a 5,0 & contato inevitável \\
\hline F & menos de 0,2 & mais de 5,0 & desconforto físico e psicológico \\
\hline
\end{tabular}

Fonte: Fruin apud Santos (1997).

Outro item importante do projeto funcional é a justificativa do melhor traçado para uma nova linha. Segundo Tupinambá (2007), a base das alternativas de traçado acompanha os eixos urbanos viários com altas demandas por transporte coletivo.

Os principais critérios analisados para a escolha da melhor alternativa de traçado são: integração com a rede metroviária existente e os demais modais, 
atendimento a demanda da área, impacto causado no uso e ocupação do solo e ao meio ambiente, características físicas de cada alternativa, necessidade de obras viárias complementares, desapropriações e custo/benefício. De acordo com o Relatório Integrado do Metrô/SP (2018), os últimos projetos funcionais concluídos foram os das linhas 19-Celeste e 22-Bordô.

A partir da definição tecnológica da linha, - que consiste no tipo de trem, tipo de via, alimentação elétrica, sinalização eletrônica, comunicação, etc -, os parâmetros geométricos da via permanente ${ }^{13}$ são estabelecidos e, adicionando as condicionantes determinadas na caracterização regional, é possível então desenhar as alternativas de traçado em planta e perfil. A rampa máxima que a composição consegue vencer é o fator determinante para o perfil da linha (TUPINAMBÁ, 2007).

O estudo do traçado contempla a distância e a profundidade das estações, assim como o perfil topográfico do trecho. Este perfil determina as cotas do topo do boleto ${ }^{14}$, ou seja, a cota de nível em que a via permanente será construída. A partir desta informação são definidas as demais cotas das estações, como a cota da plataforma, mezanino inferior e intermediários e do saguão de entrada. Já a cota dos acessos é determinada pela topografia do terreno no qual a estação será implantada.

A Figura 23 exemplifica um estudo de traçado realizado para extensão da Linha 2- Verde.

O transporte coletivo na região da futura estação é estudado, para que o projeto contemple as conexões dos diferentes modais, como ônibus, VLT, trens metropolitanos, etc.

\footnotetext{
13 Via permanente é a denominação utilizada para o conjunto de camadas e de elementos que possibilitam a passagem do trem (KLINCEVICIUS, 2011).

${ }^{14}$ Nível exatamente acima do trilho (GABARRA, 2016).
} 
Figura 23 - Exemplo de estudo do traçado: planta e perfil

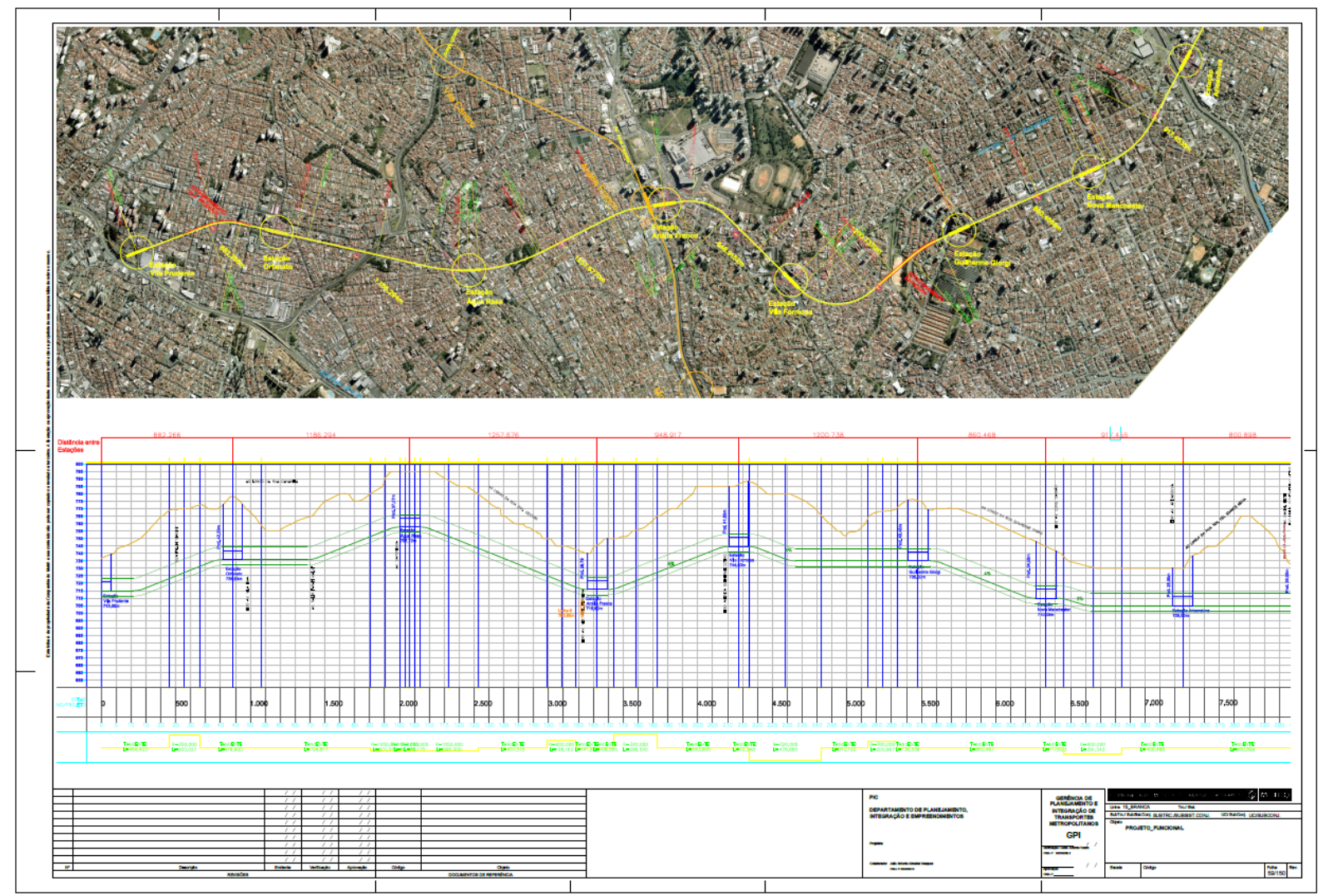

Fonte: CMSP (2011a).

Após os estudos realizados em escala macro, iniciam-se investigações pontuais para subsidiar o processo de projeto básico (CMSP,2019). Os terrenos a serem desapropriados são escolhidos, e para determinar o espaço necessário para abrigar as edificações metroviárias é desenvolvida uma implantação preliminar e cortes esquemáticos de acordo com as informações já levantadas até o momento. Nesta etapa o método construtivo da estação também é definido. A Figura 24 apresenta o estudo preliminar de uma estação de metrô. 
Figura 24 - Exemplo de estudo preliminar: implantação e corte esquemático

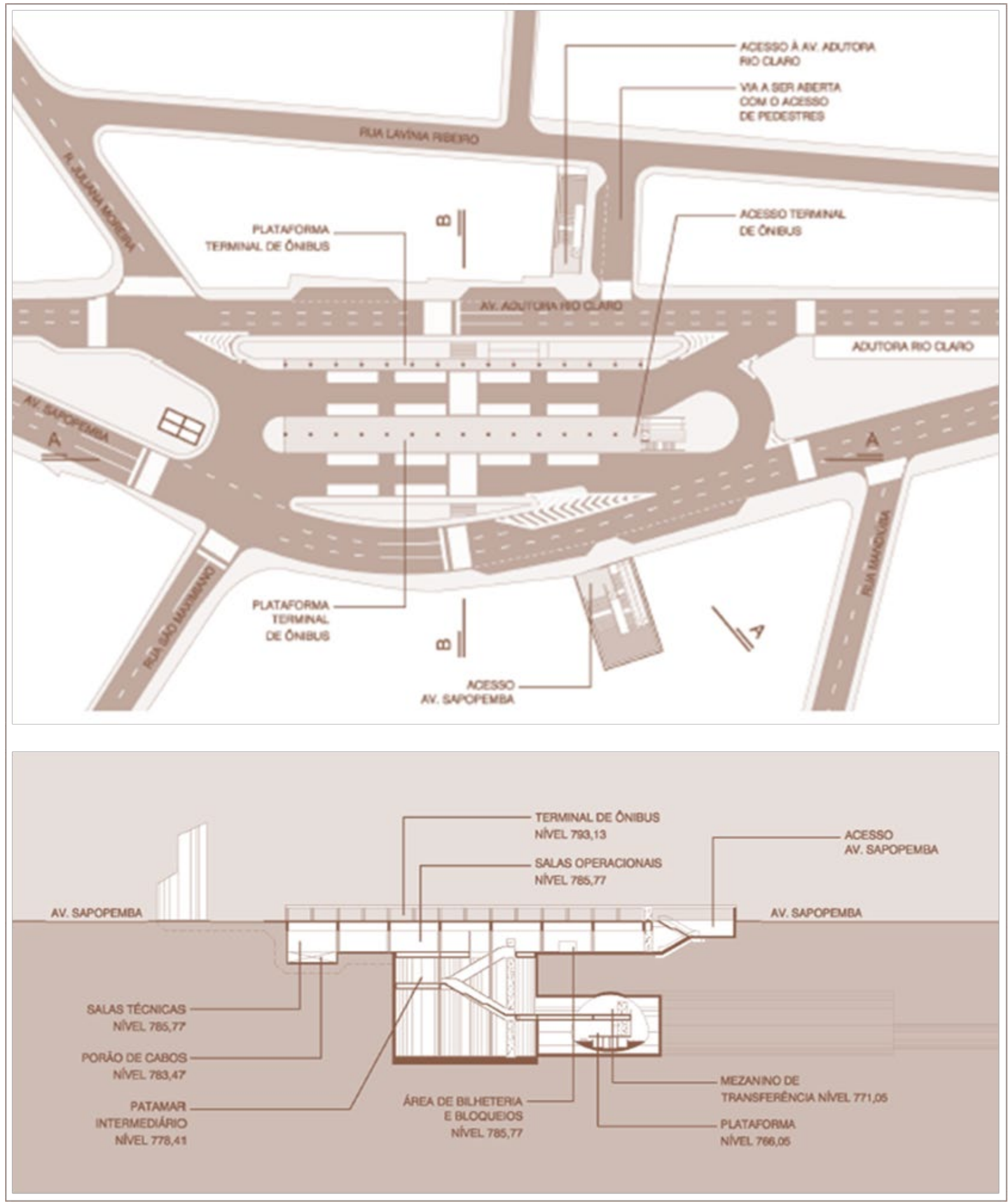

Fonte: CMSP (2011a).

A partir das definições do projeto funcional são elaborados os projetos básicos de arquitetura e de engenharia civil das estações da linha proposta. Geralmente o projeto básico de uma linha de metrô é licitado por trechos, no qual diferentes projetistas desenvolvem os projetos das diversas edificações metroviárias que compõem a linha. 


\subsubsection{Projeto Básico}

De acordo com a instrução de projeto IP-9.00.00.00/3B3-001 (2011b) do Metrô/SP, "o projeto básico consiste na etapa de definição de todos os elementos de acabamento e de comunicação visual necessários à edificação, assegurando a viabilidade técnica, a avaliação do custo da obra e a geração de subsídios para o posterior detalhamento do projeto executivo", devendo conter os seguintes elementos (CMSP,2011b):

a) Desenvolvimento da solução escolhida de forma a fornecer visão global da obra e identificar todos os seus elementos construtivos com clareza;

b) Soluções técnicas globais ou localizadas, suficiente detalhadas e representadas, de forma a minimizar a necessidade de reformulação ou de variantes durante as fases de elaboração do Projeto Executivo e execução das obras e montagens;

c) Identificação dos tipos de serviços a executar e de materiais a incorporar à obra, bem como suas especificações que assegurem os melhores resultados para o empreendimento;

d) Informações que possibilitem o estudo e a indicação dos métodos construtivos, instalações provisórias e condições organizacionais para a obra, sem frustrar o caráter competitivo para a sua execução;

e) Subsídios para montagem do plano de licitação e gestão da obra, compreendendo a sua programação, a estratégia de suprimentos, as normas de fiscalização e outros dados necessários em cada caso;

f) Orçamento detalhado do custo global da obra, fundamentado em quantitativos de serviços e fornecimentos propriamente avaliados.

O Metrô/SP possui diversas diretrizes e instruções para a elaboração do projeto básico. Os documentos discriminados abaixo são muito utilizados durante o desenvolvimento dos projetos, e por isso a inclusão deles nos itens da biblioteca BIM proposta facilitaria o processo de trabalho tanto de projetistas como de analistas.

a) IP-9.00.00.00/1N3-001 - Diretrizes para elaboração de projetos de urbanização e paisagismo;

b) IC-9.00.00.00/3B3-001 - Diretrizes para elaboração de projeto de arquitetura Estações; 
c) IC-9.00.00.00/3B3-002 - Instrução complementar dos projetos básicos de arquitetura / acabamento;

d) IP-9.00.00.00/3ZO-001 - Diretrizes para elaboração e análise de projeto básico de arquitetura;

e) IP-9.00.00.00/3Z0-002 - Diretrizes para elaboração de layout de salas técnicas;

f) IC-9.00.00.00/3B3-004 - Diretrizes para elaboração de projeto básico de acabamento e comunicação visual;

g) LM-9.00.00.00/3B3-001 - Lista de materiais de acabamento utilizados na rede básica;

h) Investigações geotécnicas preliminares;

i) IP-5.00.00.00/3I5-002 - Drenagem Superficial;

j) Modelo de Planilha para Orçamento (OR);

k) MAN-09-200 - Medição para Obras Civis;

I) MAN-10-201 - Manual para elaboração e fornecimento da documentação técnica de engenharia civil, arquitetura, geotecnia, topografia, desapropriações e via permanente;

m) MAN-10-200 - Manual para aplicação dos códigos de trechos, subtrechos e unidades de construção utilizados em documentos técnicos;

n) Projeto(s)-Padrão;

o) Especificações Técnicas;

p) Instruções de Projeto;

q) Instruções Complementares.

O Quadro 7 apresenta as principais atividades e disciplinas contempladas na elaboração do projeto básico de uma estação para o Metrô/SP. O fluxo de trabalho e as atividades podem ser alteradas conforme o edital de licitação. 
Quadro 7 - Atividades e disciplinas do Projeto Básico

\section{Atividade | Disciplina Descrição}

Recebimento e análise da documentação de referência fornecida pelo REFERÊNCIAS Metrô/SP, com ênfase ao projeto funcional e aos dados geológicosgeotécnicos.

VISTORIA

Vistoria no local, com o objetivo de diagnosticar as necessidades urbanas.

TOPOGRAFIA

$(2 \mathrm{C} 1)$
Levantamento topográfico planialtimétrico cadastral do sistema viário e alinhamento predial, com o objetivo de permitir a locação do traçado das vias e das edificações, determinar a área de influência das obras sobre os imóveis lindeiros e definir as áreas para o decreto de desapropriação.

Estudo preliminar de arquitetura contemplando a implantação das unidades construtivas e o dimensionamento dos ambientes da estação, incluindo estudos de acessibilidade e dos diversos caminhamentos de sistemas e ventilação.

\section{SONDAGENS E}

PERFIS Perfis individuais de sondagens e ensaios.

GEOLÓGICOS (4C3)

\section{RELATÓRIOS \\ TÉCNICOS (4E3/4I7)}

ARQUITETURA (4B2)

INTERFERÊNCIAS

(4D1/4D2)

\section{GEOMÉTRICO}

(4F2/4F3)
Pesquisa de valores de terrenos e avaliação para estação, poços e etc. Levantamento Cadastral Individual de Terreno e de benfeitorias, Pesquisa de Edificações Lindeiras e danos potenciais.

O projeto básico de arquitetura deverá fornecer as informações para compreensão geral da edificação e para compatibilização com as demais disciplinas.

Elaboração de desenhos de cadastro unificado das redes de utilidades públicas aéreas e subterrâneas nas áreas de interesse do empreendimento, com remanejamento das interferências.

Planta de locação dos eixos das vias, contendo malha de coordenadas, eixo das vias, locação gráfica dos pontos notáveis, locação dos aparelhos de mudança de via (AMV), cruzamentos, estações, marcos hectométricos, superelevação, dados das curvas horizontais, entrevias e Perfil Longitudinal baseado na via 1. 


\section{Atividade | Disciplina Descrição}

Perfis geológico-geotécnicos longitudinais e transversais;

GEOTECNIA

(4I7/4G9)
Interpretação das investigações e ensaios, analise do comportamento do maciço (resistência e deformabilidade), em função dos métodos construtivos de escavação, do tipo de fundação adotada, bem como do comportamento das edificações lindeiras.

DESAPROPRIAÇÃO (4E1)

Plantas com indicação detalhada das áreas necessárias, estabelecendo os perímetros de desapropriação e/ou de ocupação temporária.
PAISAGISMO

(4N3)
Projeto básico de urbanização e Paisagismo fornece informações de arruamentos, locação de guias rebaixadas, faixas de travessias, canteiros, acabamentos, forração vegetal, locação de árvores, arbustos e equipamentos urbanos ( caixa de correio, cabines telefônicas, abrigo de ônibus, bancas de jornais, lixeiras, etc.), acompanhadas de suas características, aplicações e quantidades.
SISTEMA VIÁRIO

(4F4)
Estudo do sistema viário na região abrangida pelo projeto, com elaboração de plantas, perfis, seções transversais e projeto de terraplenagem e pavimentação. Além de desenhos referentes ao desvio de tráfego e sinalização.

\section{ESTRUTURA SALAS}

TÉCNICAS (4I1/4J2)
Fundações e estrutura de concreto - Formas

Elaboração de plantas, detalhes, isométricas e memoriais descritivos das

BÁSICO HIDRÁULICA

(4S5) instalações de água potável, águas pluviais, esgoto, incêndio e bombeamento, nas estações, vias, túneis e poços, com detalhes suficientes para a quantificação de materiais e serviços necessários à contratação da execução das obras civis.

Estudos hidrológicos de bacias, cálculos de vazões, dimensionamento e locação de dispositivos de drenagem, com elaboração de plantas e detalhes dos elementos de drenagem.

\section{ESCAVAÇÕES}

(4G2/4G3/4G4) 


\begin{tabular}{|c|c|}
\hline Atividade | Disciplina & Descrição \\
\hline $\begin{array}{l}\text { CONTENÇÃO } \\
(4 \mathrm{H} 1)\end{array}$ & Sistema de contenção \\
\hline $\begin{array}{l}\text { ESTRUTURAS } \\
\text { (4J2/4K1/4K3/4K5) }\end{array}$ & $\begin{array}{l}\text { Concepção e estudo das obras provisórias; } \\
\text { Projeto básico de estruturas de concreto armado (forma e armação } \\
\text { típica), metálicas (plantas, vistas laterais, seções transversais e detalhes } \\
\text { típicos de conexões) ou mistas de todas as obras. }\end{array}$ \\
\hline TÚNEIS & $\begin{array}{l}\text { Projeto básico dos túneis em NATM, tuneladora (SHIELD); } \\
\text { Relatório Técnico de Diretrizes Básicas da Tuneladora (SHIELD) e do } \\
\text { Revestimento dos Túneis de Via do Trecho. }\end{array}$ \\
\hline $\begin{array}{l}\text { ACABAMENTOS } \\
\text { (4B3) }\end{array}$ & $\begin{array}{l}\text { O projeto básico de acabamento deverá conter a definição dos materiais } \\
\text { de acabamento, levando em conta a durabilidade, facilidade de } \\
\text { manutenção, qualidade estética, o conforto e a segurança dos usuários, } \\
\text { além de contemplar a legislação relativa a acessibilidade. }\end{array}$ \\
\hline $\begin{array}{l}\text { COMUNICAÇÃO } \\
\text { VISUAL (4B5) }\end{array}$ & $\begin{array}{l}\text { O projeto básico de comunicação visual é baseado nos Manuais Técnicos } \\
\text { de Identidade Visual da Companhia do Metrô, nos projetos padrão e nas } \\
\text { informações técnicas e operacionais. }\end{array}$ \\
\hline
\end{tabular}

Fonte: Elaboração própria, baseado em editais e contratos de projetos básico do Metrô/SP.

O projeto básico de arquitetura define o partido arquitetônico dos poços de ventilação, das estações e seus acessos, bem como dos elementos construtivos, considerando os projetos complementares (estrutura, ventilação, hidráulica e vias), assim como as instalações e equipamentos necessários para a operação, conforto e segurança dos usuários. O projeto deve contemplar a legislação relativa à acessibilidade, combate a incêndios e rota de fuga, uso e ocupação do solo (recuos, taxa de ocupação e taxa de permeabilidade), além do atendimento à legislação municipal e estadual relativo ao meio ambiente. Nesta etapa também devem ser apresentadas as soluções de urbanização e tratamento paisagístico, adequadas a uma instalação pública de grande fluxo.

Os projetos de acabamentos e comunicação visual, nomeados respectivamente com as séries 4B3 e 4B5, são elaborados a partir da aprovação do 
projeto básico de concepção arquitetônica pelos técnicos do Metrô/SP, série 3B2 ou 4B2.

No processo de projeto tradicional (2D), ou seja, sem o uso na metodologia BIM, os produtos entregues na etapa de projeto básico de arquitetura são: planta de implantação, planta das edificações, cortes transversais e longitudinais, elevações, detalhes ou ampliações, perspectivas e desenhos de apresentação, prevenção e combate a incêndio e rotas de fuga.

Esses documentos representam os elementos construtivos necessários para uma instalação metroviária, indicando as principais dimensões estruturais, todos os elementos horizontais/verticais, tais como placas de sinalização, forro, dutos de ventilação principal, iluminação principal, canal de cabos, etc. Os materiais utilizados, como por exemplo concreto, alvenaria, vidro, aço, etc., também são selecionados e indicados nesta fase de projeto.

\subsubsection{Desenvolvimento e análise do projeto básico}

O processo de projeto é iniciado com a análise dos documentos recebidos e a visita técnica ao local de implantação da estação. O projeto funcional e os estudos desenvolvidos na etapa anterior são revisados, efetuando-se a entrega do projeto preliminar de arquitetura (2B2). Após reuniões de equipe e análises, o projeto preliminar é aprovado, dando início ao projeto básico de arquitetura (4B2).

A análise crítica de projeto, executada pelos técnicos do Metrô/SP, avalia a capacidade de um projeto para atender os requisitos propostos, buscando identificar problemas e propor o desenvolvimento de soluções (CMSP, 2016). Cada disciplina, ou fase de projeto, é analisada por equipes ou profissionais específicos, sendo que usualmente o mesmo projeto é analisado por diferentes técnicos e departamentos.

Tratando-se do processo tradicional, anterior ao BIM, existem duas formas de análise dos documentos: folha de papel e folha digital. No processo em folha de papel, os técnicos analisam os projetos, fazendo anotações nos desenhos entregues a companhia. Cada anotação recebe um número, e estas são transcritas 
em um relatório de verificação, em forma de texto, estabelecendo uma relação entre os números das anotações nos desenhos e a respectiva descrição no texto. A Figura 25 apresenta um relatório de verificação do Metrô/SP.

Figura 25 - Relatório de verificação

\begin{tabular}{|c|c|c|c|}
\hline COMP AMUIA DO METROPOLITANO DE SAO PMIL O & METRÓ & RV DE-2.35.02.00/483-001 2 & 2 \\
\hline 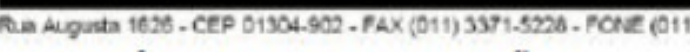 & & Emissão: 11/06/2013 & \\
\hline RELATÓRIO DE VERIFICAÇÄO & & DS: 2465 & \\
\hline
\end{tabular}

\begin{tabular}{|l|l|}
\hline De: CAC & Para: CONSÓRCIO PLANSERVI-ESTRA-EGT \\
\hline Responsável Técnico: ANA MARIA & Aprovação: \\
\hline
\end{tabular}

Objeto: ARQUITETURA - ACABAMENTO

Comunicamos que o(s) documento(s): DE-2.35.02.00/4B3-001 Rev. 2 anexo ao memorando de remessa p0181 de 23/05/2013 é considerado: NÃ̃O APROVADO

Pelo(s) seguinte(s) motivo(s):

CIA GERAL 1 - A aprovação do conjunto de desenhos e LM referentes ao Projeto Básico de Acabamento (4B3) da Estação Guilherme Giorgi só poderá ocorrer mediante análise e posterior aprovaçäo do conjunto de desenhos do projeto básico de arquitetura (4B2). As revisões eventuais no presente projeto deverão ser compatibilizadas com as revisões aprovadas no projeto da série 4B2;

CIA GERAL 2 - Inserir quadro de Documentos Complementares em todas as follhas conforme padrão enviado pelo Metrô - posicioná-lo abaixo do quadro "Projeto Básico de Acabamento" - devem constar os documentos referentes aos projetos de Civil, Estruturas Metálicas, Impermeabilizaçäo, Paisagismo, Comunicação Visual, etc;

CIA GERAL 3 - O departamento de acabamento está reticente em utilizar o forro especificado para a maior parte da estação (ED53), visto que possui um alto grau de complexidade, e deve ter a sua instalação previamente pensada e projetada em conjunto com todas as demais instalaçōes, caso contrário poderá gerar resultados estéticos e de manutenção insatisfatórios, já que não permite fácil acesso ao que estiver acima (não permite alçapões e luminárias embutidas, por exemplo). Ademais, este forro apresentou problemas relativos ao ruído causado pela vibração dos perfis tapa canal expostos à ventilação elevada. A não ser que tais aspectos possam ser garantidos pelo presente projeto, aconselhamos que utilizem o forro Baffle, que nos tem apresentado bons resultados - favor nos enviar justificativa técnica, argumentando a escolha;

CIA GERAL 4 - Garantir que o vidro da cúpula não possua tom esverdeado devido ao seu fator de proteção solar, entrando em conflito com o tom azulado utilizado no revestimento do edifício técnico-operacional sugerimos que 0 vidro possua também tom azulado;

CIA GERAL 5 - Especificar a cor de acabamento dos caixilhos - pode ser feito através de nota;

CIA GERAL 6 - Prever barras antipânico nas portas de rota de fuga, sala de bateria e voltadas diretamente para área externa - indicar no campo "observação" das tabelas;

CIA GERAL 7 - Prever Porta Cortafogo insonorizadas na sala do GGD;

CIA GERAL 8 - Prever Porta Estanque na sala de baterias;

CIA GERAL 9 - No quadro "Projeto Básico de Acabamento", substituir LM por OR;

DE-2.35.02.00/4B3-001 - IMPLANTAÇÃO - PLANTA

CIA 1 - Retirar "(ver nota 2)", pois poderia ser entendido como se a totalidade da edificação fosse objeto do projeto civil;

Atender CIA GERAL.

Fonte: MAINARDI (2015b). 
Os comentários são enviados a projetista que os analisa, revisando o projeto de acordo com os problemas ou questões apontadas. Os relatórios de verificação também são respondidos em forma de texto para sanar as questões levantadas que não sofreram alteração no projeto. Após cada análise do Metrô/SP, uma nova revisão do projeto é emitida pela contratada. Esse processo é repetido quantas vezes necessário até a aprovação dos projetos ${ }^{15}$.

No processo em folha de papel os desenhos são repassados de um departamento para o outro, em um processo em série, o que acaba dificultando e atrasando a análise. Quando a mesma é realizada através de folhas digitais, ou seja, quando os documentos são entregues em DWF (formato que permite visualização e anotações), os comentários podem ser feitos em paralelo, melhorando a produtividade e a colaboração das análises (MAINARDI, 2015). A Figura 26 apresenta a análise de uma folha digital, através da ferramenta Autodesk Design Review.

Figura 26 - Análise de projeto em folha digital

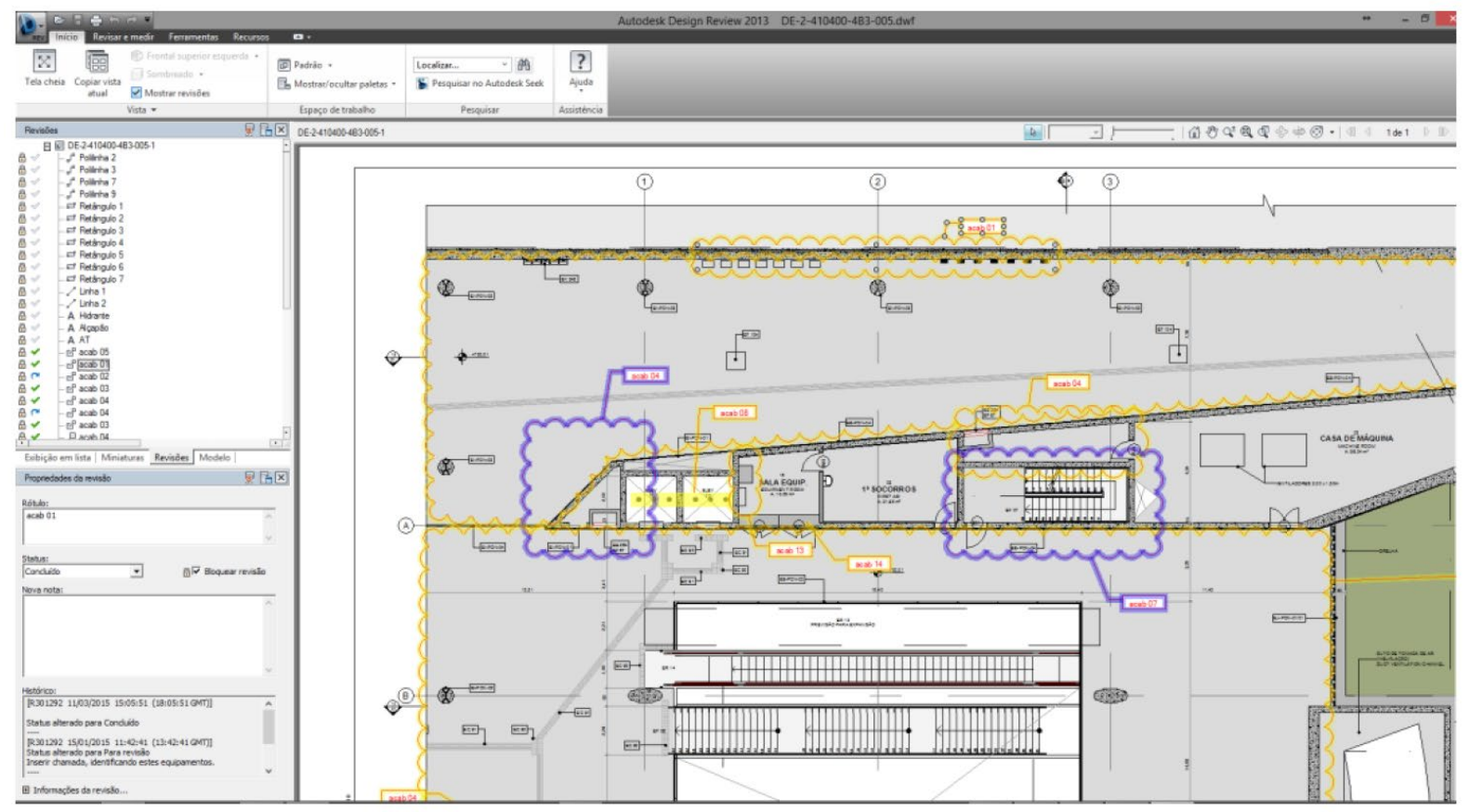

Fonte: MAINARDI (2015a).

\footnotetext{
${ }^{15}$ De acordo com o instrumento normativo MAN-10-201, a aprovação de projeto é o ato pelo qual um projeto ou documento técnico é considerado adequado aos requisitos inicialmente solicitados para aquela finalidade (CMSP, 2016).
} 
O projeto básico de arquitetura (4B2) serve de base para o desenvolvimento das demais disciplinas. Portanto após sua aprovação, os projetos de acabamentos, estrutura, hidráulica, paisagismo, comunicação visual, sistema viário, etc., são iniciados. Com o desenvolvimento das demais disciplinas, dá-se início ao processo de compatibilização dos projetos. As estações de metrô são edificações complexas, com soluções e elementos específicos, que exigem grande atenção de projetistas e técnicos quanto a análise e a compatibilização entre as disciplinas.

O projeto de acabamentos é uma parte do projeto de arquitetura onde se define os elementos e materiais a serem aplicados nas estações, considerando questões de manutenção, segurança utilitária dos materiais empregados, legislação e normatização. O projeto de comunicação visual apresenta as soluções gráficas que identificarão os ambientes e orientarão os usuários dentro das edificações metroviárias. O conceito empregado na comunicação visual é complementar aos desenvolvido no projeto de acabamentos (CMSP, 2011b).

A especificação dos materiais e equipamentos para as estações é realizada com base nos documentos técnicos que descrevem e listam os códigos, unidades e os dados geométricos de cada produto. As listas também indicam desenhos de referência, denominados como "projeto padrão"16 - PP. A partir do projeto padrão, cada projetista deve representar geometricamente os elementos utilizados no projeto, e indica-los através de códigos. Estudos sobre os PP's serão aprofundados no item 3.3 - Industrialização e padronização de estações de metrô.

\subsubsection{BIM no Metrô de São Paulo}

A partir de 2011, o Metrô/SP iniciou a implantação do BIM em suas gerências e em seus empreendimentos. Este item da pesquisa apresenta um levantamento das iniciativas para consolidação do BIM na companhia e um estudo de caso da primeira estação entregue em BIM ao Metrô de São Paulo.

\footnotetext{
16 Conforme documento interno do Metrô denominado MAN-10-201, PP's ou Projetos Padrão são definidos como "desenhos onde são especificados e detalhados graficamente os elementos de acabamento e comunicação visual, pertencentes aos diferentes trechos ou sistemas, com desenvolvimento de soluções padronizadas de projeto".
} 
Segundo o edital de concorrência da Linha 15-Prata (2017), o objetivo do BIM para o Metrô/SP é melhorar a colaboração no desenvolvimento dos projetos, possibilitar maior clareza em resoluções, melhorar a extração e a rastreabilidade das informações durante o desenvolvimento do projeto, obra e pós-obra.

A partir de 2013, nas licitações realizadas pela antiga Gerência de concepção de projeto básico civil - $\mathrm{GCl}{ }^{17}$ é exigido o uso do BIM. Nesta gerência, os projetos são analisados internamente por técnicos e profissionais que avaliam as informações do modelo 3D e dos documentos 2D, produzindo comentários que seguem para os projetistas emitirem uma nova revisão do projeto.

$O$ documento que regulamenta $e$ fornece diretrizes para $O$ desenvolvimento de projetos BIM no Metrô/SP é o MAN-10-203. Esse documento define que os modelos BIM serão utilizados para fornecer o quantitativo do projeto $e$ para detecção de interferências. Estabelece também como deve ser produzida a documentação técnica, extraída obrigatoriamente do modelo, e quais as disciplinas devem ser entregues nesta metodologia (MAINARDI, 2015). A Figura 22 apresenta uma parte deste instrumento normativo.

O próximo item da pesquisa irá apresentar um estudo de caso do primeiro projeto entregue em BIM para o Metrô/SP, a fim de absorver as lições aprendidas no processo para o desenvolvimento da biblioteca de metacomponentes BIM.

\subsubsection{Estudo de caso: Estação Ponte Grande}

O primeiro projeto desenvolvido no processo BIM no Metrô/SP foi a estação Ponte Grande, pertencente à extensão da Linha 2-Verde. A autora da pesquisa participou do desenvolvimento deste projeto, como arquiteta pela projetista SISTRAN Engenharia.

Neste momento foi elaborado um novo fluxo de projetos para a $\mathrm{GCl}$, ilustrado na Figura 27.

\footnotetext{
${ }^{17}$ Atualmente Gerência de Projetos Básicos de Transportes Metropolitanos - GPR/DPA.
} 
Figura 27 - Fluxo de projetos no processo BIM

\section{Fluxo de Projetos GCI Processo BIM}

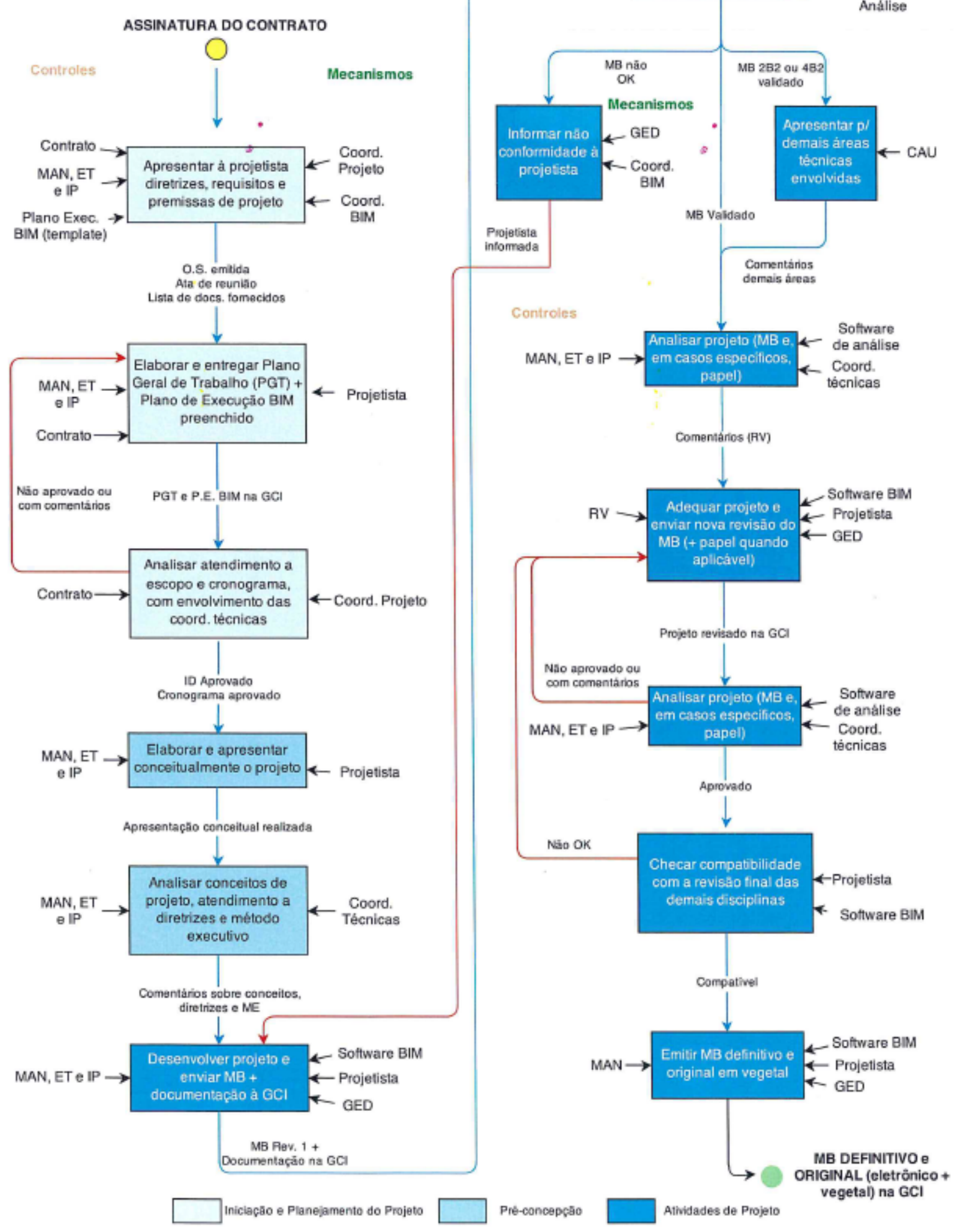

Fonte: MAINARDI (2015b). 
O projeto preliminar da estação, utilizando as informações do projeto funcional, foi elaborado pela $\mathrm{GCl}$ em software BIM. O projeto básico foi desenvolvido pela projetista SISTRAN Engenharia em conjunto com o Metrô/SP. Durante o desenvolvimento do projeto básico de arquitetura as questões de fluxo, dimensionamento dos ambientes e a posição dos edifícios que compõem a estação foram determinados, e posteriormente os projetos de acabamento, comunicação visual, estrutura de concreto, metálica e hidráulica também foram realizados em software BIM.

A ferramenta nativa utilizada no desenvolvimento do projeto de arquitetura, acabamentos, paisagismo e comunicação visual foi o Archicad, e os produtos foram entregues nas extensões: IFC, DWG, DWF, PDF e PLA. O Metrô/SP e a projetista utilizaram o software Tekla BIMsight para verificar e compatibilizar os modelos IFC das diversas disciplinas. A comunicação entre os projetistas e o Metrô/SP foi realizada principalmente através da troca de arquivos BCF - BIM Collaboration Format.

Além da análise dos documentos 2D (folhas digitais), por meio do formato DWF, o modelo IFC do projeto também foi analisado. Através do formato BCF os analistas fixavam as vistas do modelo e atrelavam a ela comentários. Estes arquivos eram enviados a projetista que revisava o projeto ou respondia o comentário do analista, criando assim históricos sobre as questões apontadas. A Figura 28 ilustra a análise do modelo na ferramenta Tekla BIMsight, com a vista do modelo e os comentários do lado direito.

A experiência com o projeto da estação Ponte Grande demonstrou melhorias relativas a comunicação e a interoperabilidade. O processo de análise do projeto contou com a colaboração de diversas gerências dentro do Metrô/SP, uma vez que o arquivo podia ser analisado paralelamente e por meio digital, resultando em um projeto com um maior nível de definição. As reuniões foram mais produtivas e eficientes, pela facilidade de visualização e pelos recursos de documentação oferecidos pelo modelo BIM (MAINARDI, 2015a). A Figura 29 mostra uma das reuniões do projeto, com o modelo projetado, facilitando as discussões do mesmo. 
Figura 28 - Análise e comentários do modelo em IFC

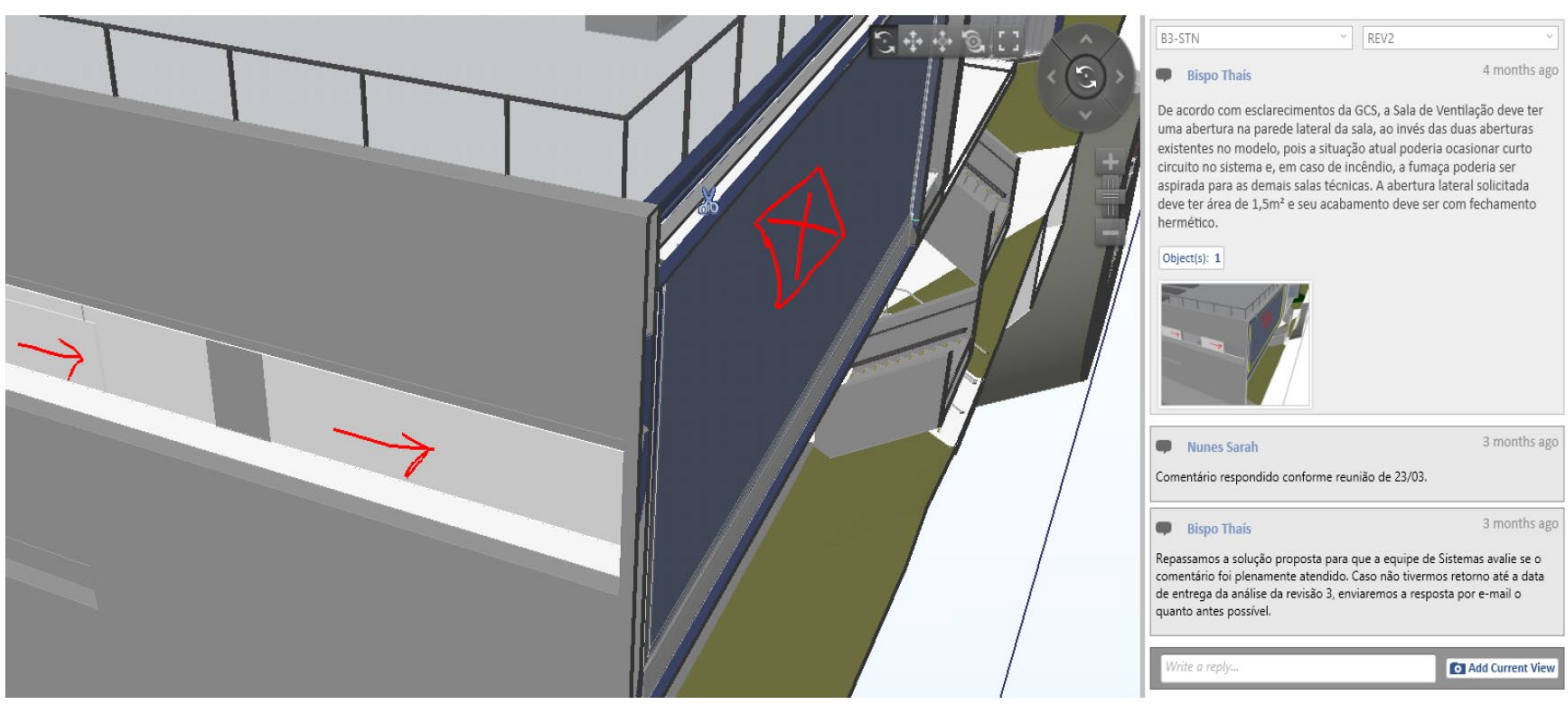

Fonte: MAINARDI (2015a).

Figura 29 - Registro de uma reunião sobre o projeto de arquitetura

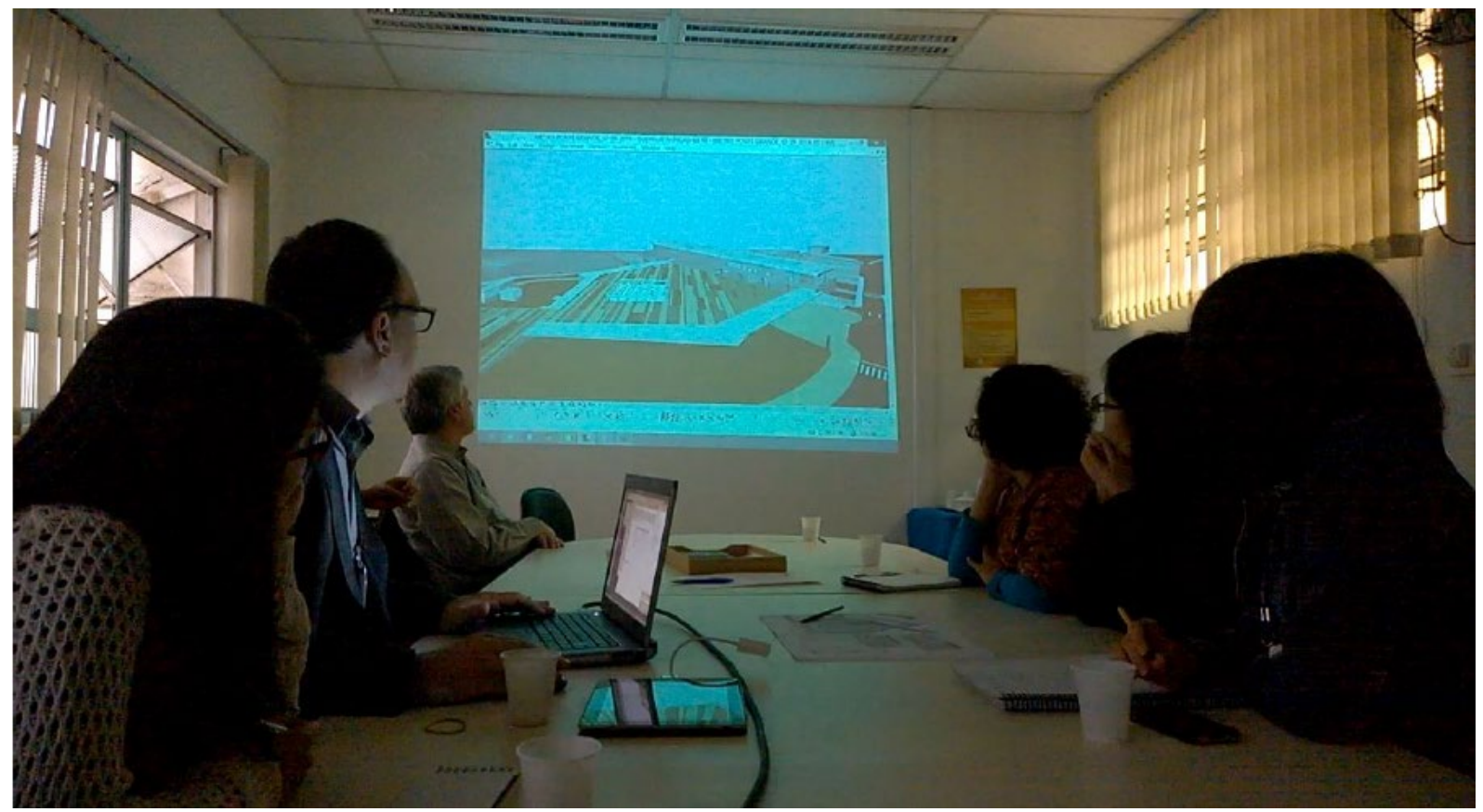

Fonte: MAINARDI (2015a).

O fluxo de trabalho deste projeto era definido por ciclos de 15 dias para análise e 15 dias para revisão do projetista. O nível de desenvolvimento do modelo foi estabelecido através dos itens que deveriam constar no orçamento para a licitação, ou seja, todos os elementos quantificados para o orçamento deveriam ser 
modelados, sendo possível extrair a relação do quantitativo direto do modelo BIM. Essa diretriz do Metrô/SP gerou um modelo bastante completo e complexo, à medida que detalhes como o acabamento em verniz das estruturas de concreto, cantoneiras e soleiras foram modeladas, para que pudessem ser visualizadas e quantificadas.

Outro resultado verificado pelo Metrô/SP e pela projetista foi o aumento do número de comentários do projeto desenvolvido em BIM. Este fato foi analisado em um artigo (MAINARDI, 2015), escrito pelo BIM Manager do Metrô/SP, no qual é feita uma comparação entre duas estações de sistema construtivo, formato e linha de implantação semelhantes. A Tabela 3 e a Tabela 4 apresentam o número de comentários, de acordo com a disciplina, e o tempo necessário para análise (em dia).

Os números comprovam o aumento tanto de comentários, quanto do número de revisões. Entretanto, de acordo com Mainardi (2015a), este resultado é consequência de um projeto com visualização mais precisa e representação mais abrangente. Outro fato apontado é o ganho de produtividade, visto que se comentou mais em menos tempo. A Figura 30 faz uma comparação entre os processos de análise tradicional e com o modelo BIM.

Tabela 3 - Número de comentários da estação Ponte Grande (projeto em BIM)

\begin{tabular}{|c|c|c|c|c|c|c|c|c|c|c|}
\hline \multirow{3}{*}{$\begin{array}{c}\text { Estação } \\
\text { Ponte } \\
\text { Grande }\end{array}$} & \multicolumn{8}{|c|}{ Revisão } & \multirow{2}{*}{\multicolumn{2}{|c|}{ Total }} \\
\hline & \multicolumn{2}{|l|}{1} & \multicolumn{2}{|l|}{2} & \multicolumn{2}{|l|}{3} & \multicolumn{2}{|l|}{4} & & \\
\hline & coment & dias & coment & dias & coment & dias & coment & dias & coment & dias \\
\hline Arquitetura & 233 & 20 & 102 & 13 & & & & & 335 & 33 \\
\hline Acabamento & 588 & 31 & 402 & 15 & 179 & 19 & & & 1169 & 65 \\
\hline $\begin{array}{l}\text { Comunicação } \\
\text { Visual }\end{array}$ & 98 & 34 & 59 & 17 & 54 & 13 & 2 & 16 & 213 & 80 \\
\hline Paisagismo & 16 & 18 & 40 & 18 & 10 & 17 & & & 66 & 53 \\
\hline Est. Concreto & 402 & 18 & 91 & 26 & 448 & 32 & & & 941 & 76 \\
\hline Est. Metálica & 40 & 24 & 5 & 35 & & & & & 45 & 59 \\
\hline Hidráulica & 79 & 14 & 45 & 11 & 21 & 20 & & & 145 & 45 \\
\hline
\end{tabular}

Fonte: MAINARDI (2015a). 
Tabela 4 - Número de comentários da estação Guilherme Giorgi (processo tradicional)

\begin{tabular}{|c|c|c|c|c|c|c|c|c|c|c|}
\hline \multirow{3}{*}{$\begin{array}{l}\text { Estação } \\
\text { Guilherme } \\
\text { Giorgi }\end{array}$} & \multicolumn{8}{|c|}{ Revisão } & \multirow{2}{*}{\multicolumn{2}{|c|}{ Total }} \\
\hline & \multicolumn{2}{|l|}{1} & \multicolumn{2}{|l|}{2} & \multicolumn{2}{|l|}{3} & \multicolumn{2}{|l|}{4} & & \\
\hline & coment & dias & coment & dias & coment & dias & coment & dias & coment & dias \\
\hline Arquitetura & 80 & 43 & 30 & 14 & & & & & 110 & 57 \\
\hline Acabamento & 83 & 79 & 45 & 25 & 10 & 7 & & & 138 & 111 \\
\hline $\begin{array}{l}\text { Comunicação } \\
\text { Visual }\end{array}$ & 22 & 16 & 22 & 21 & 5 & 28 & & & 49 & 65 \\
\hline Paisagismo & 22 & 23 & 5 & 56 & & & & & 27 & 79 \\
\hline Est. Concreto & 72 & - & 29 & 34 & 11 & 20 & & & 112 & - \\
\hline Est. Metálica & 45 & 81 & 19 & 55 & 8 & 24 & & & 72 & 160 \\
\hline $\begin{array}{l}\text { Cobertura } \\
\text { Metálica }\end{array}$ & 22 & 22 & 14 & 7 & & & & & 36 & 29 \\
\hline
\end{tabular}

Fonte: MAINARDI (2015a).

Figura 30 - Comparativo entre o processo de análise tradicional e BIM

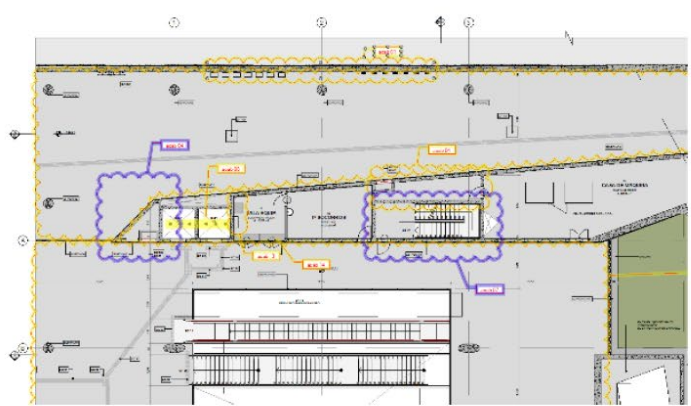

Tradicional

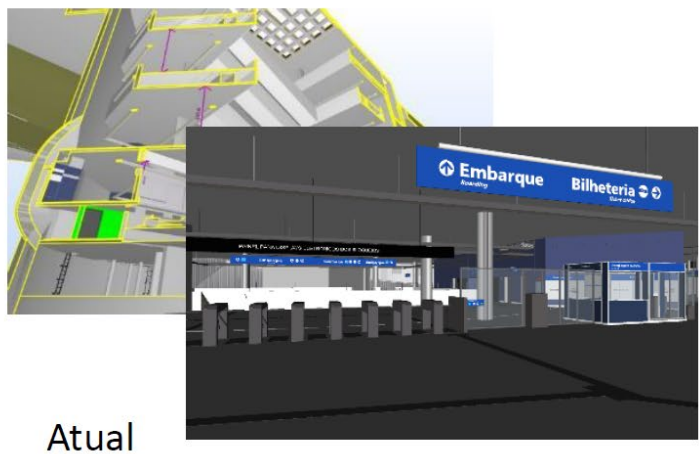

Atual

Fonte: MAINARDI (2015a).

O processo de desenvolvimento em BIM da estação Ponte Grande gerou um grande aprendizado para todos os envolvidos, evidenciando a necessidade de revisão do cronograma dos projetos e da organização dos processos, assim como um novo planejamento para os contratos e licitações em BIM. Desde então, o Metrô/SP vem desenvolvendo iniciativas para consolidar a metodologia na companhia. 


\subsubsection{Iniciativas para consolidação do BIM no Metrô/SP}

Além das licitações para o projeto básico da estação Ponte Grande (2014), projeto básico e executivo da Linha 15-Prata (2017) e do projeto básico de engenharia e arquitetura da Linha 19-Celeste (2020), o Metrô/SP vem desenvolvendo uma série de rotinas e padronizações, que contribuem para a organização e fluxo de trabalho em BIM.

A criação de uma biblioteca de objetos padronizados é uma iniciativa inicialmente relativa à disciplina de arquitetura, que organiza os padrões da companhia em termos de parametrização, materiais de acabamento, representação gráfica, etc. De acordo com Mainardi et al. (2018), "a consolidação da biblioteca contribuirá de modo significativo para a eficiência nos processos de concepção das instalações da rede metroviária, resultando em um ganho considerável para as etapas subsequentes em termos de confiabilidade da informação para execução, otimização de custos, operabilidade, manutenção e suprimentos”.

Eastman et al. (2014) confirma que a prática frequente de uma empresa com um tipo de construção que envolve famílias de objetos especiais, como a construção de edificações metroviárias, justifica o trabalho adicional para defini-las parametricamente. Elas proporcionam a inserção automática das melhores práticas da empresa nos vários contextos encontrados em diferentes projetos.

As primeiras atividades realizadas para o desenvolvimento da biblioteca foram treinamentos sobre modelagem e padrões, assim como uma revisão técnica dos PP's, considerando aspectos como o levantamento da frequência de uso, necessidade de revisão técnica e atualização de descrições.

A equipe de técnicos do Metrô/SP decidiu modelar a biblioteca internamente, principalmente para que os técnicos adquirissem expertise e maturidade suficientes para manutenção e expansão desta biblioteca de objetos. Em junho de 2017, foi iniciado o desenvolvimento de 34 elementos das disciplinas de Acabamento e Paisagismo. Posteriormente a essa concepção foi notada a necessidade da elaboração de um documento com os padrões preestabelecidos para os objetos BIM da companhia. 
Além das questões do processo de projeto tratadas neste item, a discussão sobre a padronização dos projetos metroviários também é levantada na pesquisa, pois está diretamente relacionada a viabilidade do artefato proposto. $O$ item 3.3 da pesquisa irá discutir esta questão, o método construtivo e as possíveis tipologias das estações de metrô.

\subsection{INDUSTRIALIZAÇÃO E PADRONIZAÇÃO DE ESTAÇÕES DE METRÔ}

A padronização da indústria da construção é desejável por diferentes razões: garantir produtos seguros, interoperáveis e sustentáveis, derrubar barreiras comerciais e aumentar a eficiência através da harmonização de especificações técnicas, normas e regulamentos, além de ganhar com o potencial inerente as tecnologias digitais. A interface padrão entre módulos e componentes pré-fabricados aumentará a compatibilidade do sistema e atuará como um poderoso driver de produtividade, acelerando a industrialização do setor (WEF, 2016).

A indústria da construção, assim como outras indústrias de produção, é regulada por uma infinidade de padrões, diretrizes e códigos. No entanto, percebese que no setor da construção há uma tendência de padronização e otimização apenas em nível individual ou organizacional, e não no processo inteiro. Entretanto quando olhamos para o BIM como uma metodologia de entrega de ponta a ponta é importante entender a diferença estratégica entre os padrões das organizações e o da indústria como um todo (POLJANŠEK, 2017).

As estações de metrô são edificações destinadas essencialmente ao embarque e desembarque dos trens, e ao pagamento da tarifa. Dentro de determinada tipologia, orientada principalmente pelo método construtivo, essas edificações possuem configuração espacial bastante semelhante, indicando que a padronização das soluções projetuais associada a industrialização dos elementos construtivos pode ter impactos positivos na construção deste tipo de edificação.

De acordo com Gabarra (2016), a adoção de padronização e industrialização da construção de edificações metroviárias permite um menor custo 
proporcional, à medida que dilui os custos de equipamentos, gera elementos mais baratos, além de adicionar confiabilidade e controle de prazos.

Seguindo uma abordagem padronizada para criar e manter estações, o Network Rail - departamento público que administra as ferrovias na Inglaterra aponta alguns benefícios desta conduta (NETWORK RAIL, 2015):

a) Redução de esforços e custos de projetos;

b) Consistência da aparência (marca);

c) Manutenção facilitada pelo uso de componentes conhecidos;

d) Economia de custo através do gerenciamento de compras em grandes volumes;

e) Potencial de feedback e melhoria do produto;

f) Maior controle de qualidade e confiabilidade;

g) Redução de perigos e erros humanos através da familiaridade.

Desde 2015 a companhia inglesa tem contratado avaliações de maturidade BIM que destacaram a importância da criação de uma política de implantação BIM. Atualmente a Network Rail está elaborando uma estratégia para alcançar o BIM Nível 3, e como parte desta trajetória a empresa criou um portal BIM com orientações e procedimentos para a utilização do BIM em seus projetos (NETWORK RAIL, 2019). Através da adoção da metodologia BIM pretende também criar uma biblioteca de produtos homologados, que resultará em projetos mais coerentes, maior eficiência, maior garantia de qualidade, custos reduzidos de projetos e aquisição de produtos (NETWORK RAIL, 2015).

Alguns países da Europa, como a França, adotam a padronização como um meio eficaz, econômico e consistente de produzir estações de qualidade. A Figura 31 demonstra alguns componentes padronizados de estações na França. 
Figura 31 - Exemplo de componentes padronizados para estações na França

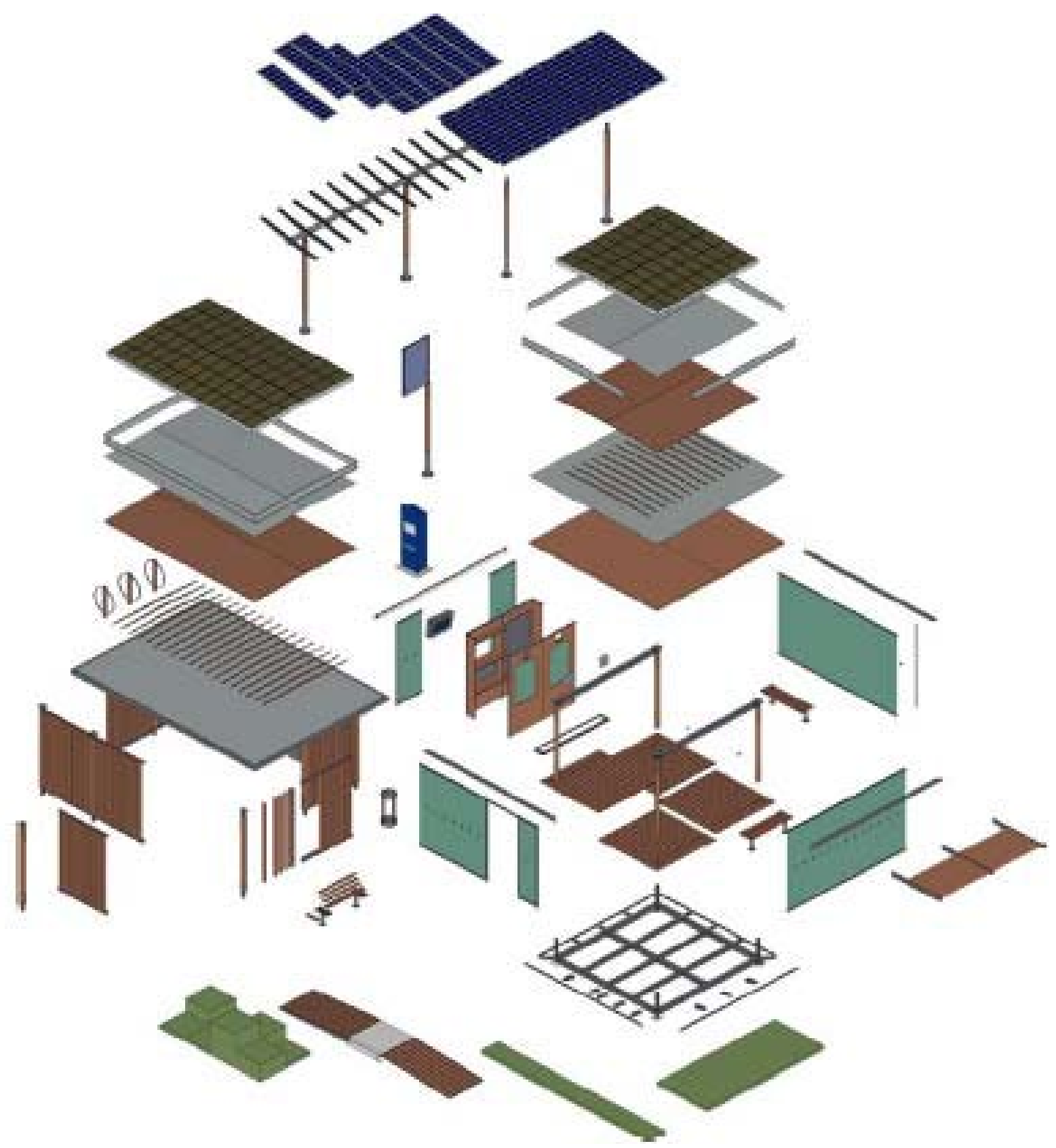

Fonte: Network Rail (2015).

O Metrô/SP também possui componentes padronizados que são especificados e detalhados nos projetos padrão (PP's). Os PP's dos elementos arquitetônicos e de mobiliário são um instrumento importante para o desenvolvimento e a análise dos projetos básicos. Estes desenhos fixam diretrizes de projeto e instalação, e são usados na concepção das estações, poços de ventilação e pátios de manobra, entre outras edificações da rede metroviária (MAINARDI et al., 2018). O desenvolvimento e a utilização destes projetos padrão 
demonstram a preocupação do Metrô/SP em adotar soluções padronizadas e com qualidade comprovadas. A Figura 32apresenta o projeto padrão das lixeiras utilizadas nas plataformas, denominadas EK05.

Figura 32 - Projeto padrão (PP) EK05: lixeira

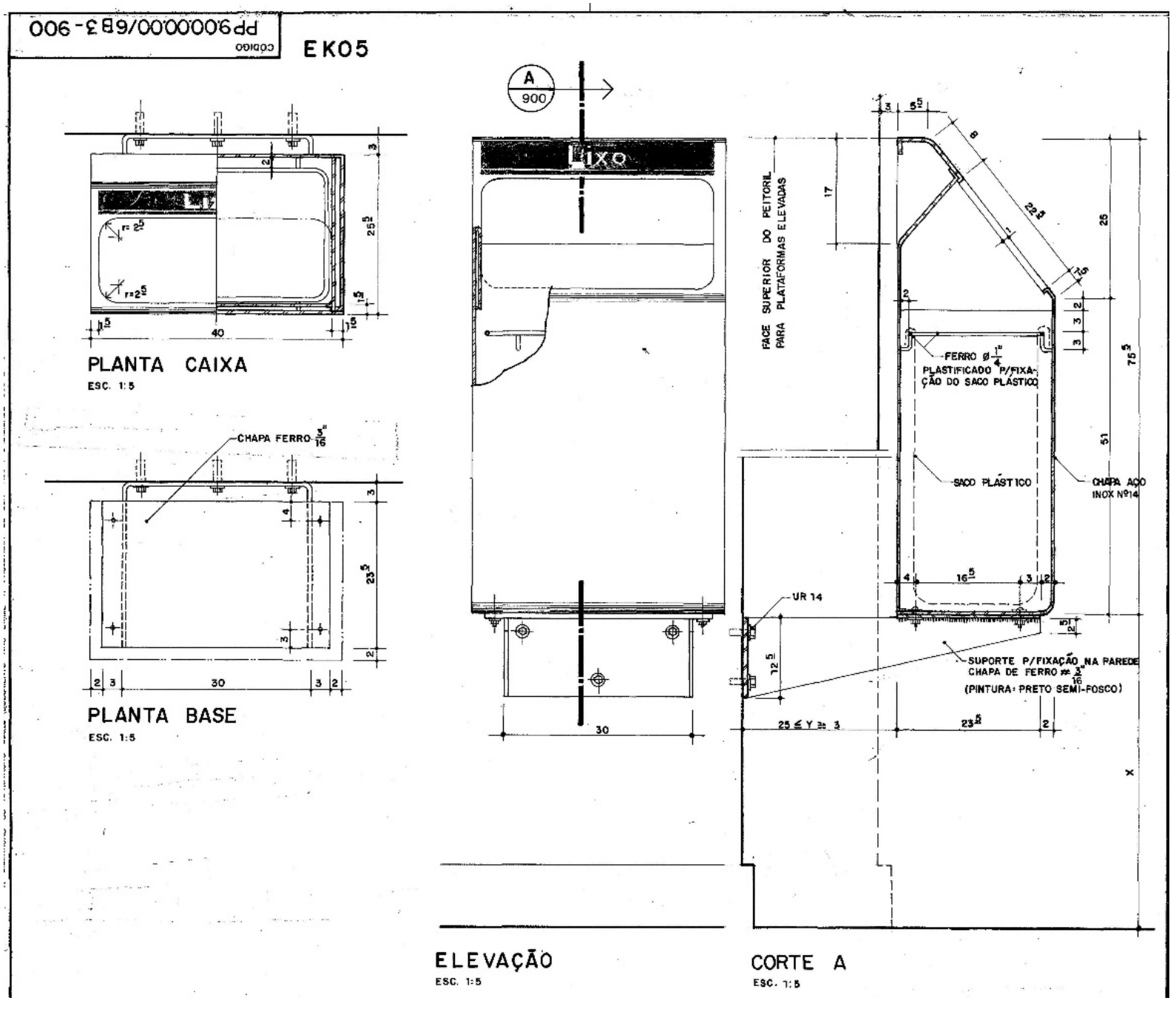

Fonte: CMSP (1978).

Além da padronização de componentes, a pesquisa propõe a padronização projetual das estações através dos diferentes métodos construtivos utilizados, visando a criação de uma linha de produção para construção de vias, túneis e estações, industrializando assim a expansão da rede de Metrô em São Paulo. O item a seguir apresenta as soluções estruturais mais utilizadas pela CMSP. 


\subsubsection{Métodos construtivos}

O método construtivo das estações é determinante para o partido adotado, constituindo-se em um elemento central desde as primeiras etapas do projeto funcional até o desenvolvimento do projeto executivo e da obra. A escolha da solução estrutural das estações está condicionada a diversos fatores, como as características físicas e de densidade ocupacional das áreas atravessadas, às técnicas construtivas disponíveis e ao seu custo de implantação. Ocorre, portanto, uma variação de estruturas, que podem ser ora em superfície, ora elevadas, ora subterrâneas (CMSP, 2019d). O Quadro 8 apresenta os tipos de metrô, de acordo com sua implantação.

Quadro 8 - Tipos de Metrô

\section{Metrô de}

Superfície
Indicado para regiões de baixa ocupação, vazios urbanos, faixas previamente garantidas por legislação ou canteiros centrais de avenidas com larguras adequadas.

As vias são assentadas em lastro sobre dormentes de madeira ou concreto protendido.

Grande volume de desapropriações, que elevam o custo final. Construção de muros na extensão da via, isolando áreas e impedindo seu desenvolvimento. Pode causar poluição do ar e sonora, perturbações no sistema viário, etc.

\section{Metrô}

Elevado

Melhores resultados obtidos quando é implantado em faixas desocupadas ou avenidas com largura superior a 40 metros (maior distância das fachadas).

Existem 3 opções de estrutura: metálica, concreto moldado in loco e concreto prémoldado.

Causa grande impacto à paisagem urbana. Devido a limitações do material rodante, a alternativa pode ser inviabilizada para locais de topografia muito acidentadas.

\section{Metrô}

Subterrâneo

Apropriado para áreas densamente ocupadas, proporcionando menor impacto à superfície, menor volume de desapropriações, facilidades para o remanejamento de grandes interferências enterradas, reduzidas interrupções do tráfego e preservação do patrimônio histórico. 
Os métodos construtivos disponíveis para execução são: trincheira ou VCA (Vala a Céu Aberto), túnel mineiro (NATM - New Austrian Tunnelling Method) e mecanizado, ou por máquina tuneladora (TBM - Tunnel Boring Machines).

O método VCA causa impacto na dinâmica da cidade durante a construção e grande número de desapropriações, devido a obra de superfície. Não é adequado para regiões de topografia acidentada.

Fonte: Elaboração própria, baseado em CMSP (2019d).

Em um levantamento das estações de metrô existentes da Rede Metropolitana de São Paulo - RMSP, as estações subterrâneas aparecem em maior número. Como as condições necessárias para construção de vias elevadas e de superfície estão cada dia mais restritas na cidade, o estudo irá contemplar as soluções estruturais subterrâneas, a fim de apresentar alguns dos elementos e métodos construtivos que irão compor a biblioteca de metacomponentes BIM para o Metrô/SP. O Gráfico 1 apresenta os tipos de estação existente da RMSP e os respectivos anos de inauguração.

Gráfico 1 - Estações de metrô: tipo e ano de inauguração

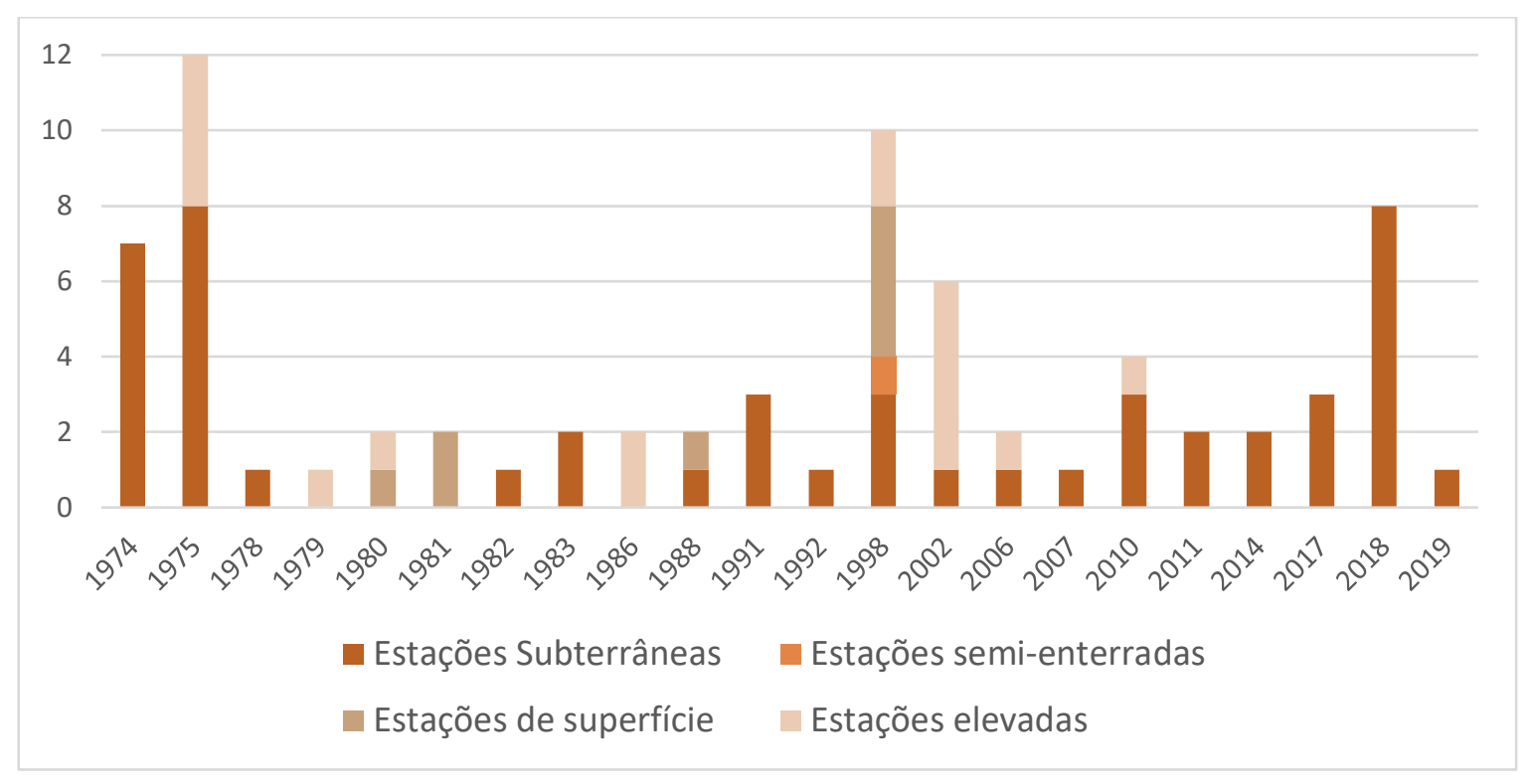

Fonte: Elaboração própria (2020), baseado em CMSP (2019d).

Conforme apresentado no Quadro 8, os métodos construtivos utilizados para execução de estações subterrâneas são: trincheira ou VCA (Vala a Céu 
Aberto), túnel mineiro (NATM - New Austrian Tunnelling Method) e mecanizado, ou por máquina tuneladora (TBM - Tunnel Boring Machines).

Nos anos 60, o método construtivo adotado era predominantemente subterrâneo conhecido como trincheira ou VCA - Vala a Céu Aberto. De acordo com Gabarra (2016), "o sistema construtivo consiste em abrir uma vala ao longo de toda a extensão dos túneis e estações e, após executada sua contenção e impermeabilização, é feita a laje de cobertura, sobre a qual é reconstituído o tecido urbano de ruas, praças etc que foi rasgado para construção de vias e estações subterrâneas". A Figura 33mostra o VCA da estação AACD, da linha 5-Lilás em execução.

Figura 33 - Estação AACD, linha 5-Lilás: Lajes intermediárias em execução

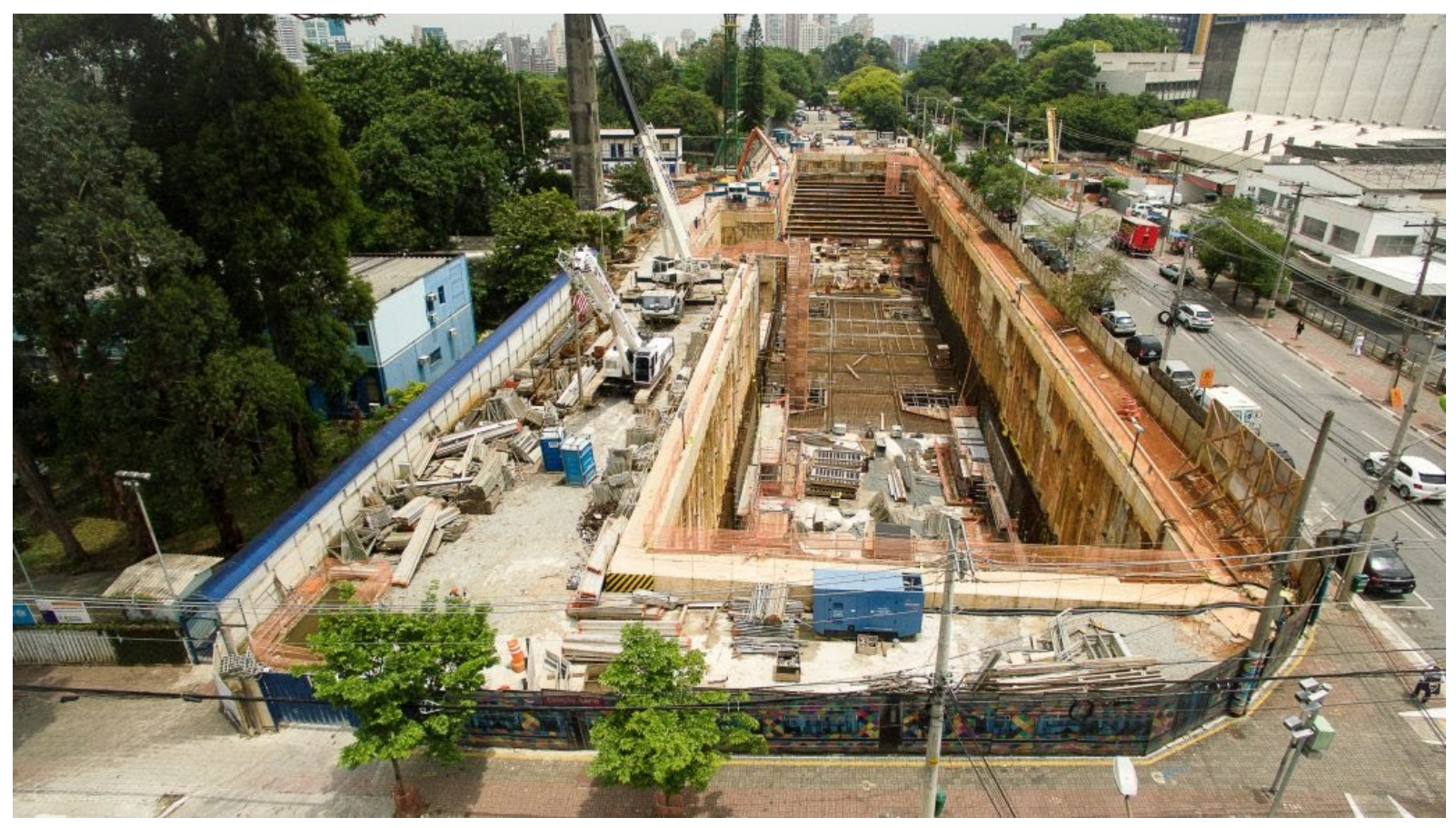

Fonte: Archsolo (2021).

Uma vantagem desse sistema são as estações próximas a superfície, agilizando o embarque e desembarque. Entretanto, devido a sua alta interferência na superfície e o baixo recobrimento, de até $20 \mathrm{~m}$ de profundidade, o método é indicado em áreas de relevo plano, onde não há interferência com o sistema viário, ou onde seja possível desviá-lo sem grandes transtornos (CMSP, 2019d). A Figura 
34 aponta os principais procedimentos para construção de estações no método VCA.

Figura 34 - Procedimentos para execução de trincheiras ou VCA

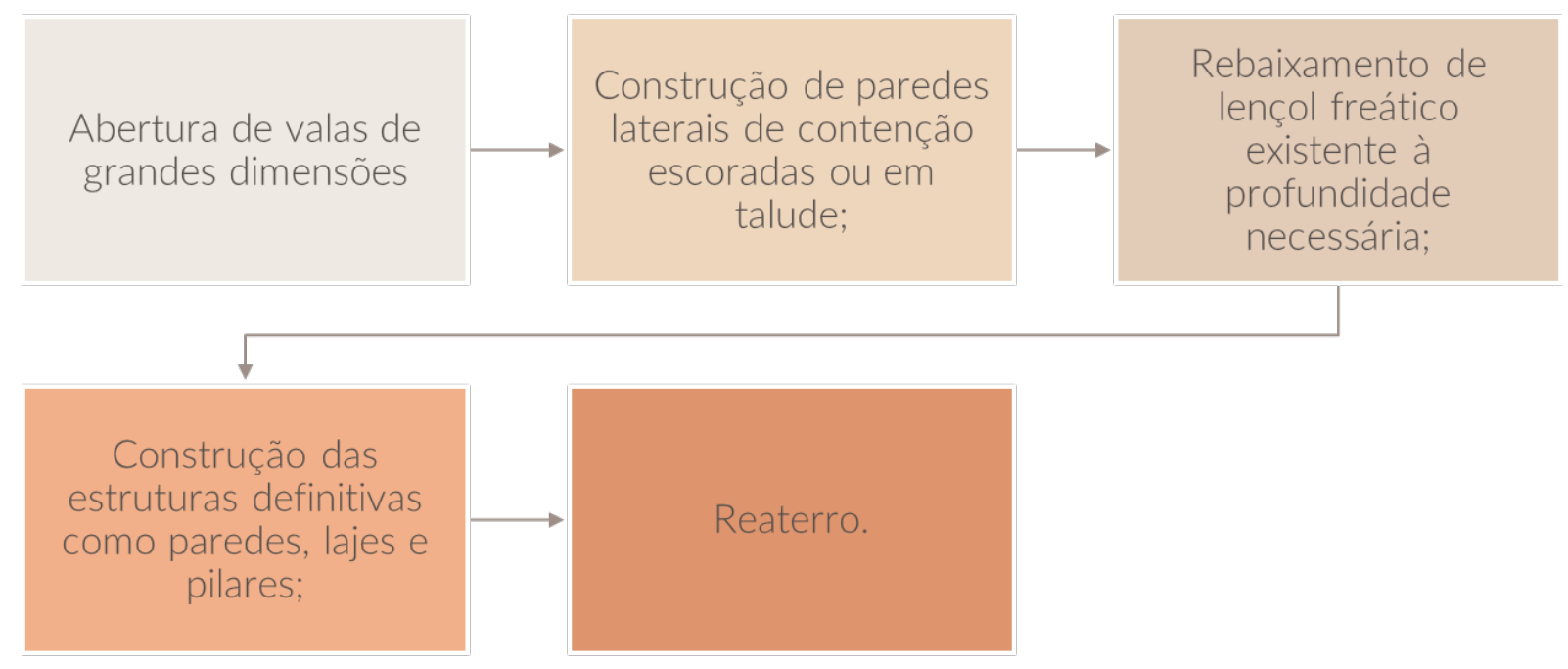

Fonte: Elaboração própria, baseado em CMSP (2019d).

Na Linha 1-Azul, no trecho Jabaquara - Liberdade tanto a via quanto as estações seguiram o método construtivo em VCA. As estações são marcadas pelos grandes vazios e lajes escultóricas, criados pelas escavações em decorrência da obra, e aproveitadas para iluminação e qualidade espacial pelo arquiteto Marcello Fragelli (GABARRA, 2016).

Outro método utilizado na construção de túneis e estações subterrâneas de grandes dimensões é o NATM (New Austrain Tunnelling Method). Para a execução de túneis o método consiste na escavação sequencial do maciço utilizando concreto projetado como suporte, associado a outros elementos como cambotas metálicas, chumbadores e fibras no concreto, em função da capacidade autoportante do maciço. Dependendo das condições do solo, esse método permite diferentes dimensões de seções (CMSP, 2019d). A Figura 35 apresenta a seção típica do túnel do corpo da estação Chácara Klabin, escavado no método NATM. 
Para a construção de estações, o método é conhecido como NATM vertical. Ele é utilizado para a escavação de poços secantes ${ }^{18}$, que podem ter números variados, abrigando todo o programa de uma estação ou apenas parte dele.

Figura 35 - Seção típica do túnel em NATM

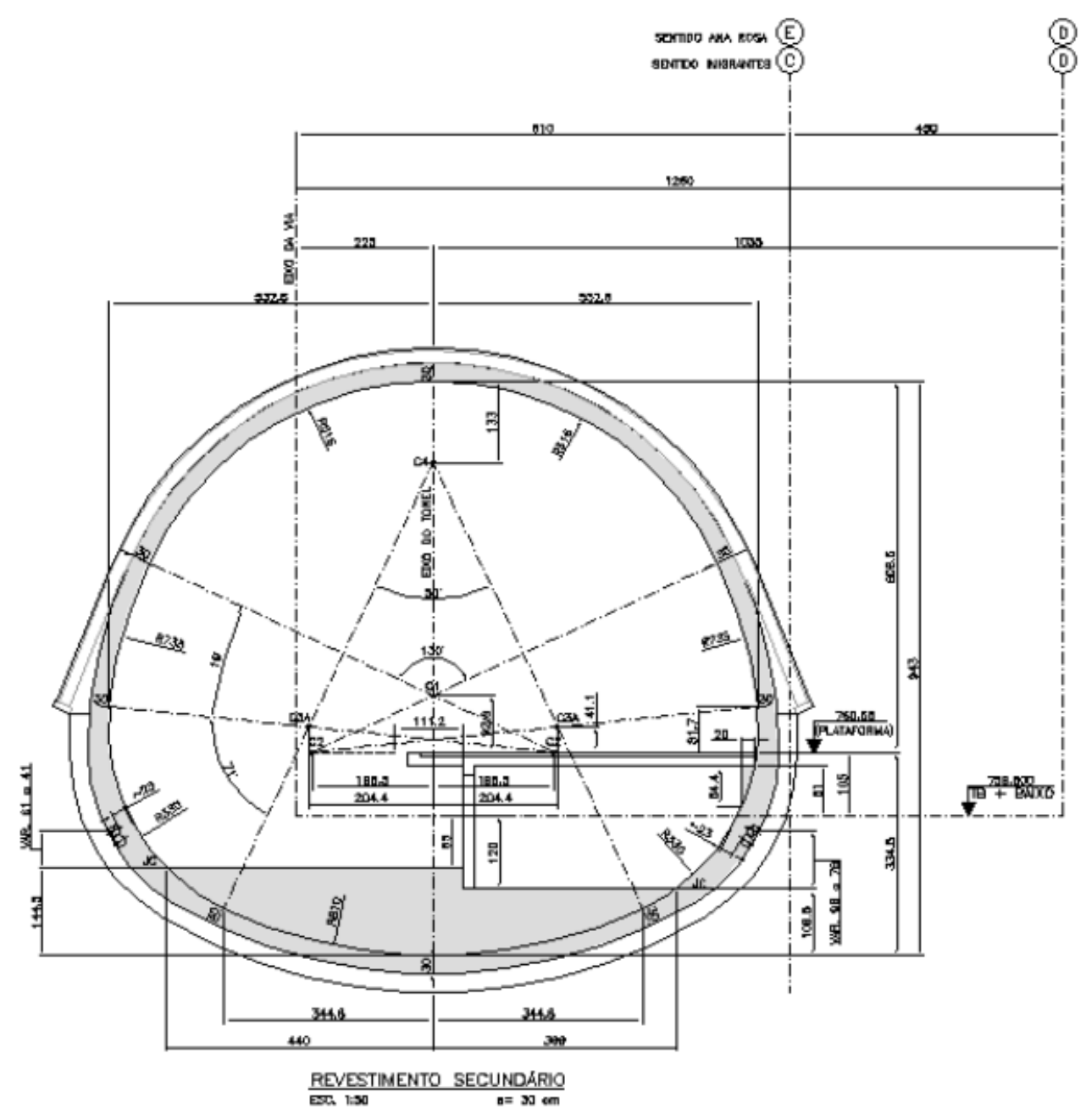

Fonte: Neto et al (2006).

A escavação de túneis no método mecanizado (TBM - TUNNEL BORING MACHINES) utiliza máquinas que, sob a proteção de uma couraça metálica, executa a escavação e monta o revestimento segmentado pré-moldado de concreto (ou metálico). O avanço da máquina se dá pela reação de macacos contra os anéis de revestimento já montados. No caso de TBM para rocha, sem couraça, o avanço se dá mediante sapatas ancoradas nas paredes laterais do túnel (CMSP, 2019d). A

\footnotetext{
${ }^{18}$ Poços circulares interseccionados cuja soma resulta em uma grande vala (GABARRA, 2016).
} 
Figura 36 representa os esquemas de funcionamento dos principais tipos de TBM do tipo couraça, esse método também pode ser chamado de Shield, máquina tuneladora, método não destrutivo (em oposição ao método destrutivo do VCA) ou ainda, como é popularmente conhecido, "tatuzão" (GABARRA, 2016).

Figura 36 - Funcionamento do shield

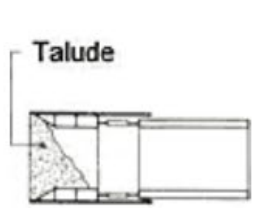

Suporte natural

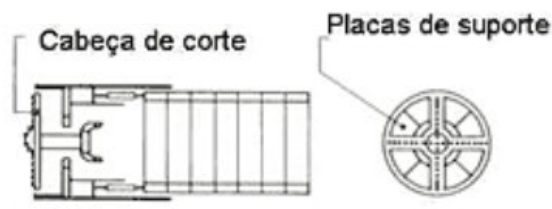

Suporte mecânico

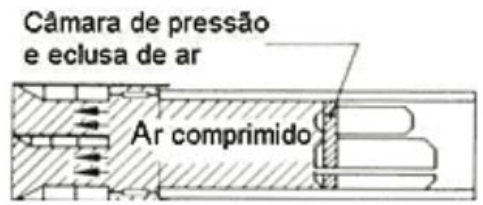

Suporte por ar comprimido

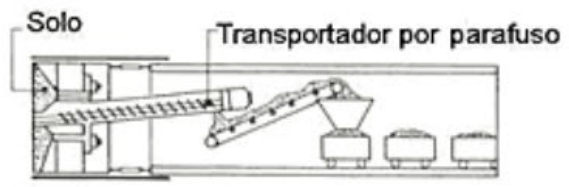

Suporte por pressão de terra balanceada EPBS

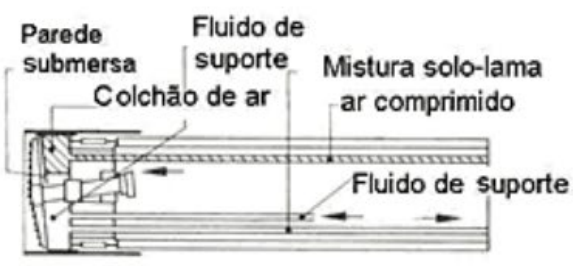

Suporte por bentonita (Shurry)

Fonte: CMSP (2019d).

A utilização de Shield, para a construção dos túneis que abrigam as vias, industrializou esse processo, aumentando a produtividade e a segurança nas escavações. Essa prática permitiu a inauguração de grandes trechos de via na Linha 4-Amarela, consagrando o sistema para a escavação de túneis, diferente do que ocorreu com as estações que foram entregues com grandes atrasos, levantando a questão da industrialização no caso destas edificações (GABARRA, 2016).

Dos métodos construtivos apresentados, os não destrutivos, como o NATM e o TBM, são uma tendência para as novas linhas, uma vez que permitem menor interferência na superfície e entorno direto. Comprovando a tendência citada, o Gráfico 2 apresenta o uso de cada método na construção das linhas 1-Azul, 2Verde, 4-amarela e 5-Lilás. A linha 3-Vermelha foi excluída do estudo pois tem a maior parte construída em superfície (GABARRA, 2016). 
Gráfico 2 - Tipo de método construtivo por empreendimento

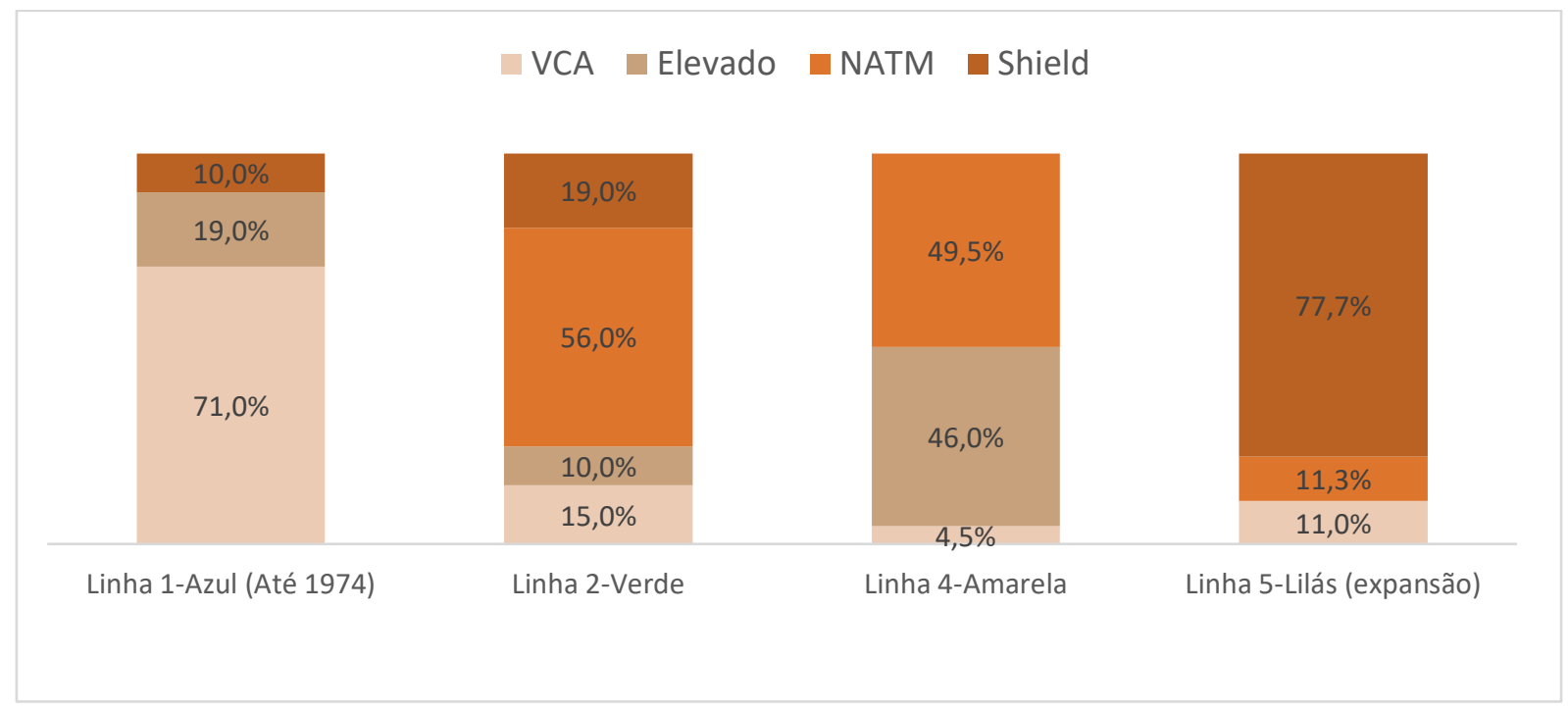

Fonte: Gabarra (2016).

O item a seguir descreverá a tipologia das estações subterrâneas, destacando questões que podem simplificar os projetos de estações, visando a industrialização e a padronização das construções, de forma a tornar o projeto factível em menor prazo, com maior controle dos custos e com menos falhas.

\subsubsection{Tipologia das estações de Metrô}

Segundo os estudos de Oakley (2017) a organização das estações subterrâneas de metrô pode ser descrita a partir de cinco áreas principais:

a) Acessos externos: localizados em lotes desapropriados ou passeios.

b) Salão de passageiros - em geral na forma de mezanino localizado no primeiro nível enterrado. Neste espaço ocorre a comunicação entre os acessos e as áreas pagas, portanto é o local onde estão instalados as bilheterias e os bloqueios.

c) Áreas das plataformas de embarque e desembarque.

d) Áreas destinadas à operação - com escritórios e espaços de apoio para funcionários.

e) Salas técnicas - salas de equipamentos, áreas de manutenção, reservatórios.

O fluxograma com a disposição das áreas citadas acima é apresentado na Figura 37. 
Figura 37 - Programa de estações de metrô
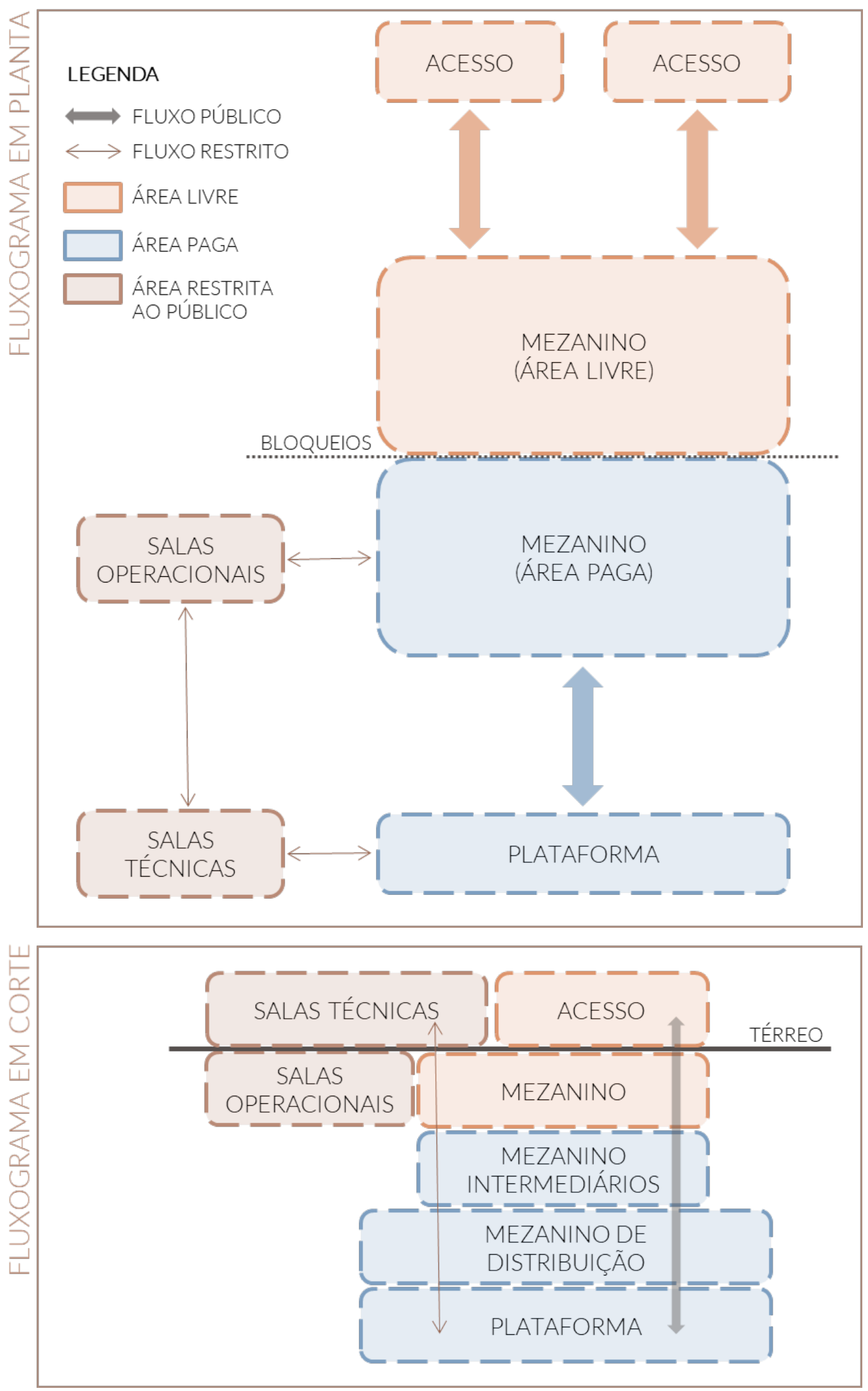

Fonte: Elaboração própria (2020). 
O fluxo de passageiros ocorre dos acessos externos, passando pelos mezaninos, chegando à plataforma de embarque/desembarque. Essas áreas são públicas e dimensionadas, principalmente, de acordo com a demanda da estação. As partes técnica e operacional da estação possuem acesso restrito ao público. As salas operacionais devem estar conectadas com a área paga do mezanino, ou em casos onde o espaço de implantação da estação é pequeno, podem estar junto ao edifício de salas técnicas. A parte técnica deve ter ligação tanto com a plataforma e o porão de cabos, quanto as salas operacionais.

A disposição vertical das principais áreas das estações é demonstrada na Figura 37.

Gabarra (2016) estudou a padronização e industrialização na construção do metrô de São Paulo, apresentando uma análise da expansão da Linha 5-Lilás. Segundo o autor, todo um trecho de linha pode apresentar um mesmo padrão de estação, conforme suas características de densidade construtiva, padrão urbano e relevo da região onde se encontra. As primeiras premissas apresentadas pelo autor, para alcançar um projeto integrado de toda a rede da RMSP, são:

a) Padronização do modal: definição das características físicas da rede para padronização de toda sua infraestrutura;

b) Padronização do suporte às vias: superfície, elevada e subterrânea (por túneis) - escavada por Shield;

c) Continuidade no planejamento;

d) Estratégia construtiva global: necessária para viabilizar a produção em série dos elementos que compõem as estações, visando um raciocínio de linha de produção para a instalação da malha.

O Quadro 9 apresenta a sugestão de Gabarra (2016) para padronização da rede metroviária da RMSP.

Após a definição das premissas do modal e a consolidação do planejamento da rede, Gabarra (2016) propõe que o tratamento padrão das estações seja considerado de acordo com o tipo de trecho que a estação será implantada, dividindo-as em três grupos principais, conforme a Figura 38. 
Quadro 9 - Premissas para padronização da rede da RMSP

Modal Metrô de alta capacidade

Tipo de Standard, alavancada pela produção chinesa, a escolha por sistema padrão, com

bitola soluções de "prateleira" é justificada pela redução do custo.

Tipo de via Subterrânea, escavada por Shield

Por catenária, possibilidade de uso de tensão maior (1500V) do que o terceiro trilho

Alimentação (750V), permitindo o uso de cabos de alimentação com seção de menor área e consequente economia.

Plataforma $\quad 136 \mathrm{~m}$ de comprimento

Fonte: Elaboração própria, partir de GABARRA (2016).

Figura 38 - Grupos de estações

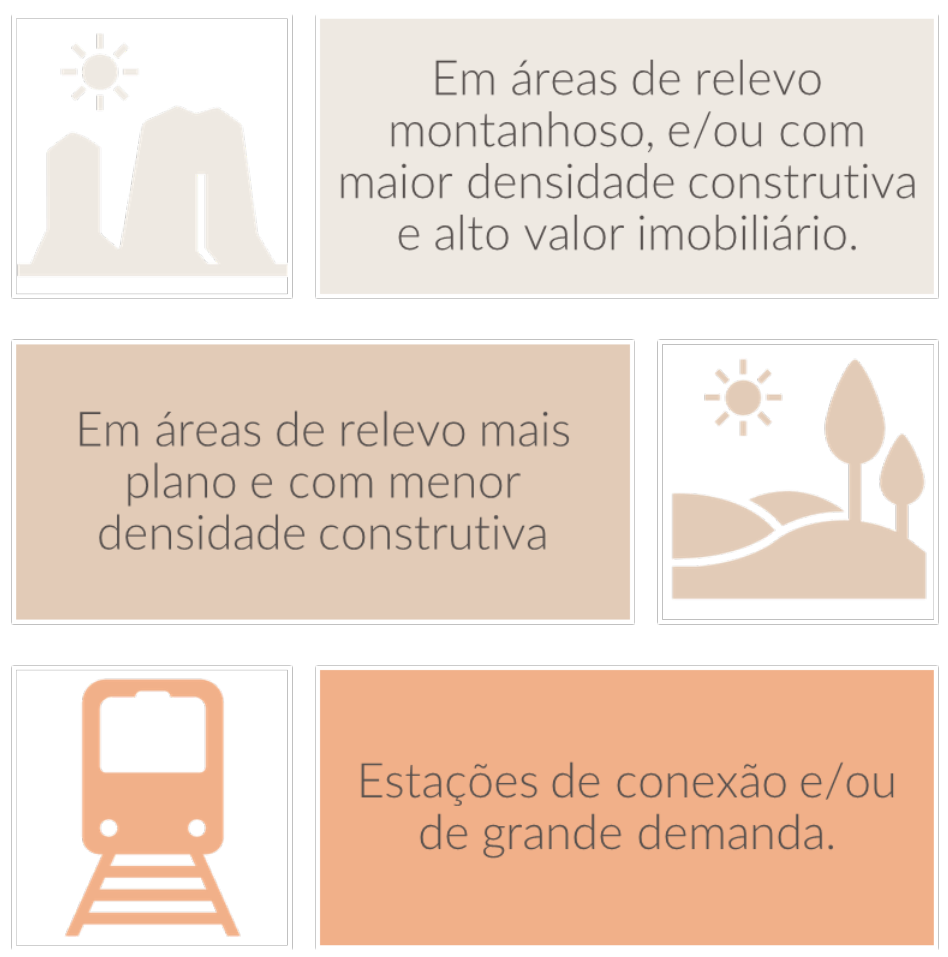

Fonte: Elaboração própria, partir de Gabarra (2016).

As características das estações locadas em trechos de relevo montanhoso, e/ou com maior densidade construtiva e alto valor imobiliário são: túnel NATM para plataformas e mezanino de distribuição, aliados à poços secantes e túnel de ligação para acesso de passageiros e funcionalidades necessárias 
(GABARRA, 2016). Esse esquema padrão possui algumas variações conforme a posição e a dimensão dos poços secantes, de acordo com o esquema demonstrado na Figura 38.

Quando o centro do poço está alinhado com o eixo da via não é necessária a execução de um túnel de ligação, condição também que favorece o fluxo de passageiros na estação. Este tipo de estação apresenta um sistema de circulação bastante enxuto, exigindo que parte do programa de necessidades fiquem em construções externas ou em alargamentos rasos da vala.

O túnel NATM conta com plataforma laterais, e com um mezanino sobre a via, por onde é feita a distribuição dos passageiros. Segundo Gabarra (2016) esse túnel também pode ser executado com a metodologia TBM, considerando a tipologia de estação com poço deslocado, e fazendo alguns ajustes, como a sobreposição das plataformas. Considerando esta configuração as estações feitas com plataforma em túnel podem ser padronizadas, acrescentando confiabilidade aos projetos, custos e prazos.

No outro grupo de estações, em trecho de relevo mais plano e com menor densidade construtiva, se viabilizam as estações com plataforma em VCA, podendo utilizar o sistema de contenção retangular ou de cinco poços secantes, dependo das condições do sitio, conforme ilustrado na Figura 39.

O sistema de poços secantes, devido à geometria, permite maiores extensões de parede sem escoramento. Por ser um elemento determinante para o layout e para as escadas rolantes, a modulação dos escoramentos por estroncas deve ser padronizada nas estações. Neste tipo de estação, Gabarra (2016) sugere que a locação das salas técnicas seja dentro da vala, uma vez que o espaço escavado é aproveitado e a distribuição dos cabos é feita de maneira mais direta.

No caso das estações de conexão e/ou grande demanda, a padronização fica comprometida por conta das exigências legais especificas que estas devem atender e também para que sejam providas de conforto para seus usuários. Nestes casos Gabarra (2016) sugere a elaboração de projetos específicos que considerem as características das linhas, conexões e do entorno dessas estações. 
A estrutura da biblioteca de metacomponentes BIM proposta para o Metrô/SP será baseada nos estudos de Gabarra (2016) sobre a padronização das estações de metrô de São Paulo, conforme apresentado neste item.

Figura 39 - Exemplos de tipologias e métodos construtivos
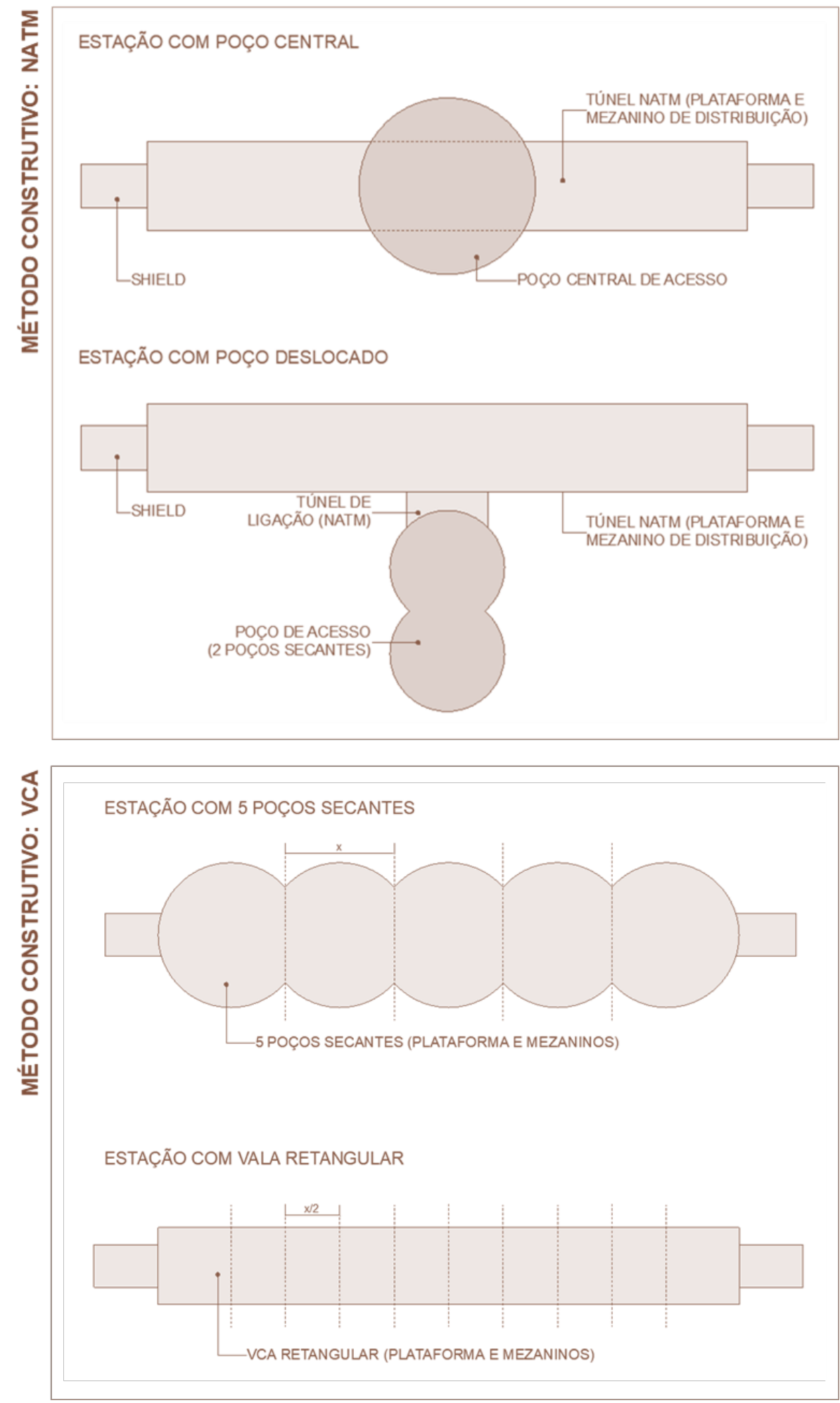

Fonte: Elaboração própria (2020). 

CAPÍTULO 4 | BIBLIOTECA DE METACOMPONENTES BIM PARA O METRÔ/SP 



\section{4 | BIBLIOTECA DE METACOMPONENTES BIM PARA 0 METRÔ/SP}

A biblioteca BIM idealizada para o Metrô/SP é um acervo composto por metacomponentes de edificações metroviárias. O termo "metacomponente" é utilizado para designar que os itens da biblioteca possuem mais de um componente. O prefixo "meta" indica algo que transcende, que vai "além de", como por exemplo no termo "metafísica", que designa todas as questões referentes a um plano da realidade situado além do mundo físico.

A primeira questão a ser explorada é a estrutura da biblioteca proposta, analisando quais as tipologias de projeto, ou partes das edificações, possuem potencial para compor este compilado de modelos. Após esta definição, o desenvolvimento de um metacomponente será descrito, apresentando as características de modelagem, as regras incluídas no modelo e os principais parâmetros para viabilização da ferramenta.

Com o objetivo de aumentar a produtividade dos projetos e a qualidade das licitações, a viabilidade da biblioteca está relacionada a quatro características fundamentais: utilização de projetos padronizados, objetos e soluções homologadas pelo Metrô/SP, elementos e materiais vinculados às tabelas de referência e a parametrização dos metacomponentes, conforme ilustrado na Figura 40.

A padronização das soluções projetuais é um aspecto de extrema relevância, pois a partir de um projeto definido é possível modelar a edificação ou parte dela, estabelecendo vínculos entre os elementos construtivos. Desta forma, o layout dos ambientes é fixado pelo projeto padrão, e as modificações são feitas apenas por parâmetros pré-estabelecidos. 
Figura 40 - Composição dos metacomponentes

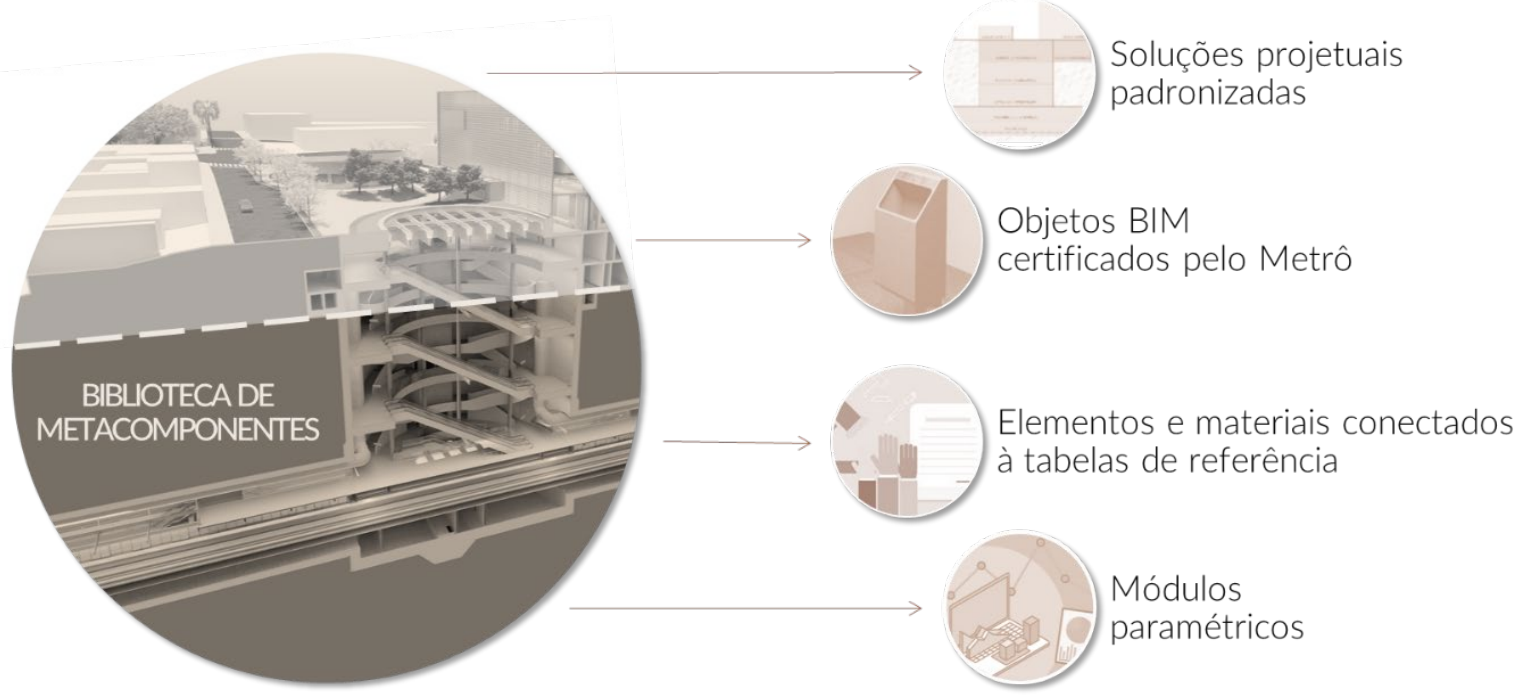

Fonte: Elaboração própria (2020).

Nos ambientes técnicos, poucas alterações são permitidas. Já nos espaços públicos mais aspectos da edificação podem ser modificados, como por exemplo os acabamentos e os elementos de fechamento dos vãos internos e escadas. O metacomponente oferece as opções de acabamentos mais utilizados pelo Metrô/SP e diferentes perfis de fechamento. A possibilidade de utilização de novos materiais e perfis é viável, desde que sua criação seja controlada, padronizada e orientada por um guia específico.

A parametrização do metacomponente garante que o mesmo possa ser utilizado em estações de diferentes escalas e linhas. Portanto, é necessário definir quais aspectos são variáveis ou fixos em cada metacomponente, baseando-se em instruções e diretrizes técnicas do Metrô/SP para o desenvolvimento de projetos. A partir da modificação dos parâmetros propostos será possível avaliar soluções, ou projetar partes das edificações, de forma rápida e precisa.

As soluções arquitetônicas, estruturais e de sistemas, assim como os objetos e equipamentos utilizados nos metacomponentes devem ser homologados pelo Metrô/SP. Desta forma são embutidos conhecimentos corporativos baseado em esforços anteriores nos projetos, produção, montagem e na manutenção acerca do que funciona e do que não funciona (EASTMAN et al., 2014). 
Os objetos e materiais que compõem os metacomponentes devem estar conectados a tabelas de referência para orçamento. Com a parametrização dos módulos será possível fazer estudos de custos dos projetos, alterando parâmetros específicos, como, por exemplo, a largura das plataformas, o número de mezaninos intermediários ou o pé-direito dos pavimentos.

Por outro lado, a utilização de projetos padronizados limita a abrangência da biblioteca em partes específicas de estações, conforme será apresentado no item 4.1 - Estrutura da biblioteca.

\subsection{ESTRUTURA DA BIBLIOTECA}

Após estudos sobre a padronização de estações metroviárias apresentam-se neste capítulo da pesquisa as tipologias de projeto ou setores das edificações, que possuem vocação para compor a biblioteca.

Os metacomponentes da biblioteca podem ser divididos de acordo com o tipo de trecho em que a estação será implantada, ou por setores que possuem maior individualidade e funções específicas dentro das estações, como por exemplo as salas técnicas e operacionais. Desta forma, é proposta uma divisão em quatro grupos principais, conforme ilustrado na Figura 41.

Figura 41 - Estrutura da biblioteca

Fonte: Elaboração própria (2020). 
Os grupos A e B são constituídos por metacomponentes das chamadas estruturas de contenção profundas. Conforme analisado no item 3.3 da revisão bibliográfica, as soluções projetuais dessas estruturas podem se repetir diversas vezes ao longo de uma linha com mínimas ou mesmo nenhuma modificação. Essa proposta parece bastante adequada, uma vez que atualmente já é possível notar esta repetição do padrão construtivo em projetos de estações da Linha 2-Verde, conforme ilustrado na Figura 42.

A biblioteca deve contar com metacomponentes de vários métodos construtivos para atender diferentes tipos de terrenos e profundidade de estações.

As estruturas de contenção rasas, localizadas na parte superior das edificações, frequentemente necessitam de ajustes de acordo com a trama urbana local e condições especiais de cada estação. $O$ projeto das estruturas de contenção rasas deve ser desenvolvido caso a caso, e a ele deve ser incorporado o metacomponente de contenção profunda escolhido para a estação em questão.

Os grupos C e D comportam os metacomponentes de partes das edificações que possuem funções específicas e características semelhantes em diversas estações, como, por exemplo, os sanitários, as salas operacionais e técnicas. Mesmo que não sejam soluções projetuais definitivas, esses módulos podem se configurar como referências de projeto para aprimorar e agilizar a produção das estações.

A Figura 43 apresenta um esquema com partes de uma estação, indicando os locais no qual poderiam ser utilizados metacomponentes para o desenvolvimento do projeto, e onde seria necessário combinar o uso de projetos específicos com os metacomponentes de setores individualizados. 
Figura 42 - Repetição do padrão construtivo: projetos Linha 2-Verde
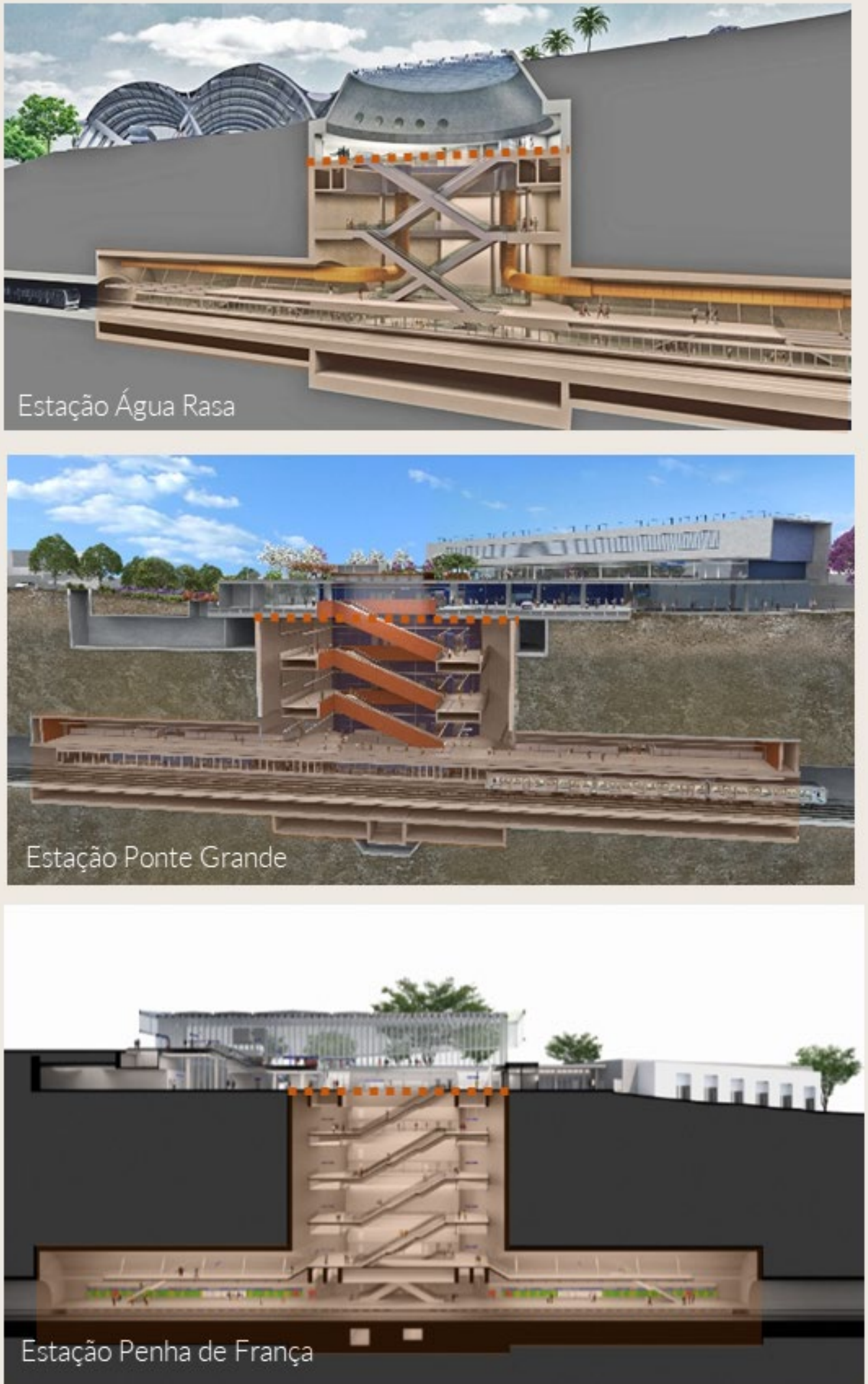

Fonte: METROCPTM (2020), BVY (2014). 
Figura 43 - Desenvolvimento de projeto: metacomponente x projeto específico

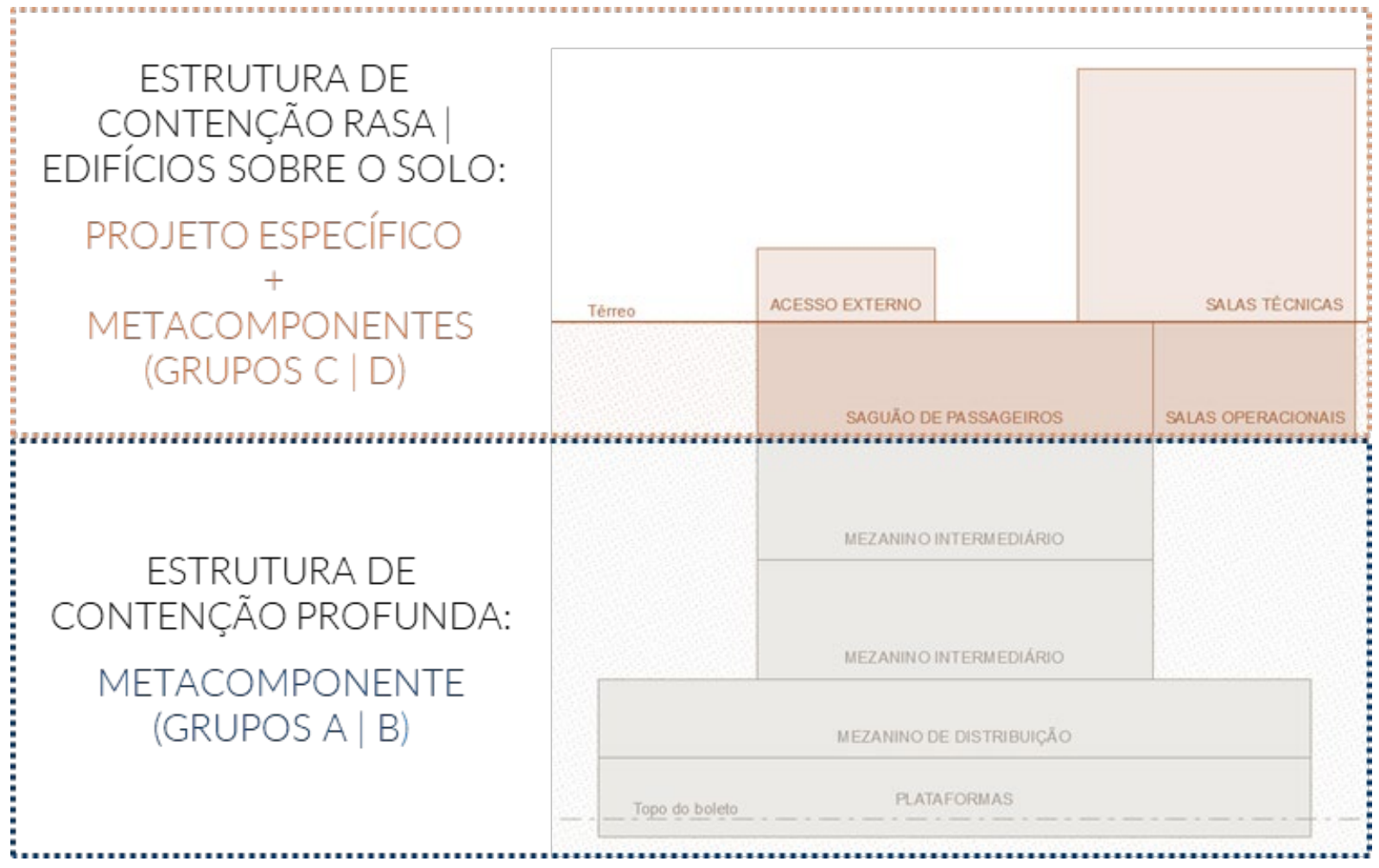

Fonte: Elaboração própria (2020).

\subsubsection{Grupo A - Estação com plataformas em túnel}

A implantação das estações deste grupo deve ser em trechos de relevo montanhoso, e/ou com maior densidade construtiva e alto valor imobiliário. $\mathrm{O}$ metacomponente deste tipo de estação é composto pela parte subterrânea da estação, excluindo-se a parte da estrutura de contenção rasa, uma vez que a mesma possui particularidades dependendo dos níveis do terreno e a situação do entorno, que devem ser estudadas caso a caso.

O modelo é composto pelo(s) poço(s) secante(s), no qual estão locados o(s) mezanino(s) intermediário(s), e pelo túnel NATM, no qual se encontram o mezanino de distribuição e as plataformas. Os níveis mais baixos da estação, onde se situa o porão de cabos e algumas partes técnicas também são partes deste módulo.

Esse grupo de estações possui alguns tipos de composição, que serão apresentadas através de croquis na Figura 44. É importante contemplar essas 
variações, pois a opção de cada um deles depende da locação do terreno em relação à via, e também dos parâmetros geotécnicos da área. Podem haver diferentes opções de túneis das plataformas, se considerada a opção dos túneis executados na metodologia TBM.

Figura 44 - Metacomponentes do Grupo A

Croqui: Estação com poços deslocados + túnel NATM

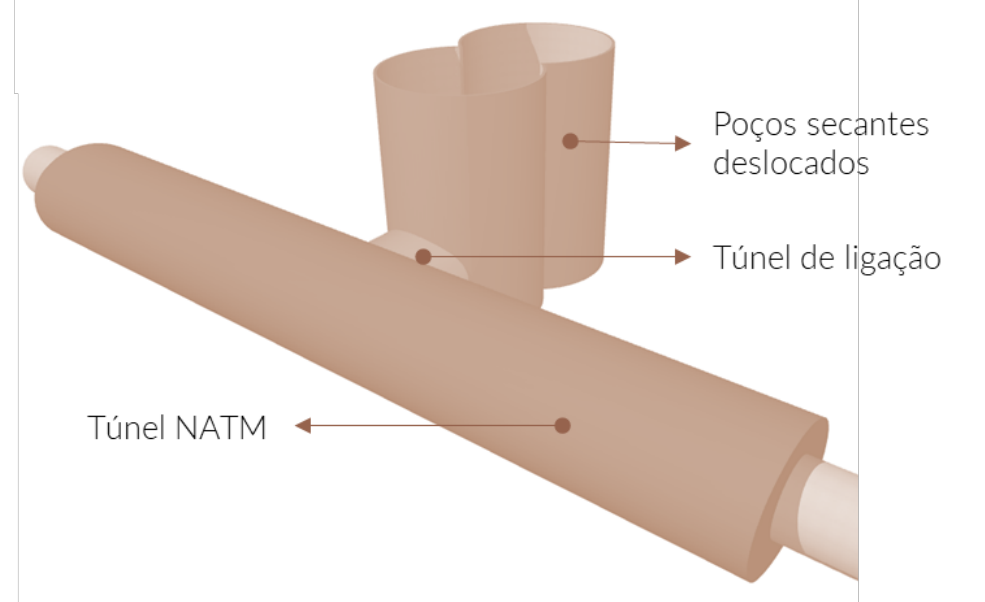

Croqui: Estação com poço deslocado + túnel TBM

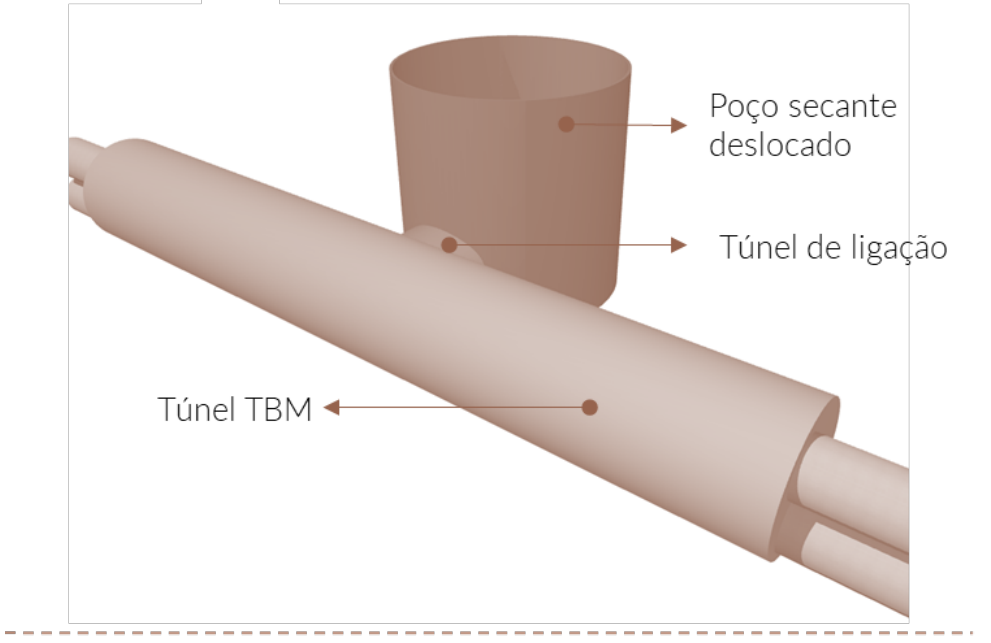

Croqui: Estação com poço central + túnel NATM

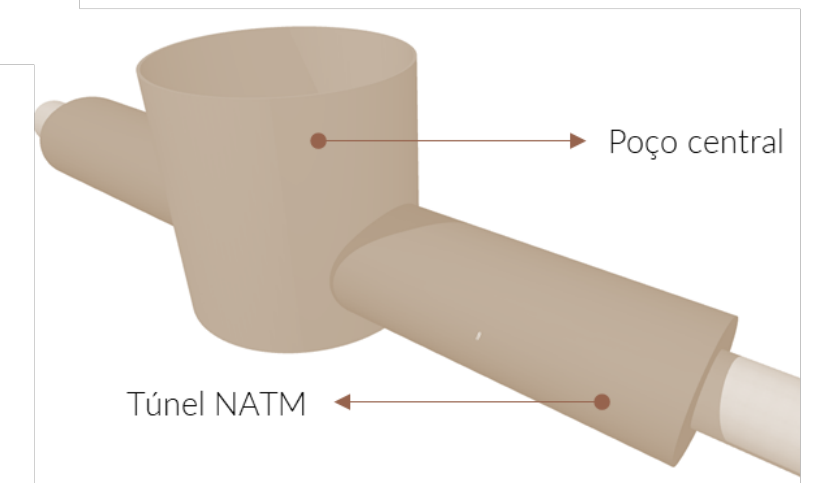

Fonte: Elaboração própria (2020). 


\subsubsection{Grupo B - Estação com plataformas em VCA}

As estações deste grupo são ideais para trechos de relevo mais plano e com menor densidade construtiva. As edificações podem ter sistema de contenção retangular e de cinco poços secantes. A escolha do método construtivo é realizada de acordo com a condição do solo no local a ser implantada a estação.

Devido ao maior volume de escavação, esses metacomponentes contemplam praticamente todas as partes da estação, como as plataformas, o mezanino de distribuição, o saguão de passageiros, assim como as salas técnicas e operacionais, restando apenas os acessos e a urbanização da parte sobre a vala para serem projetadas posteriormente.

O dimensionamento da vala é relevante neste tipo de estação, e depende do porte da edificação, que é balizado pela demanda de passageiros, prevista no projeto funcional. Os tipos de metacomponentes deste grupo de estações são ilustrados na Figura 45.

Figura 45 - Metacomponentes do Grupo B

\section{Croqui: Estação com 5 poços secantes secantes}

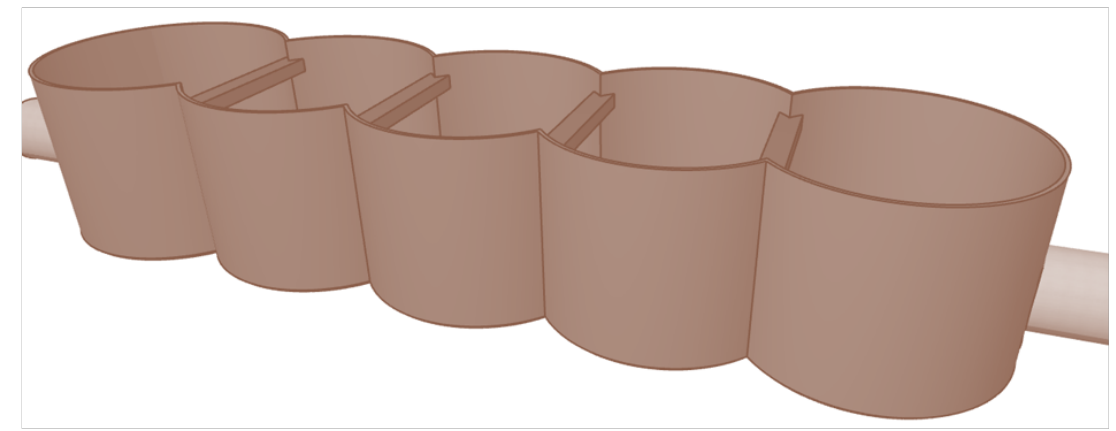

Croqui: Estação em VCA

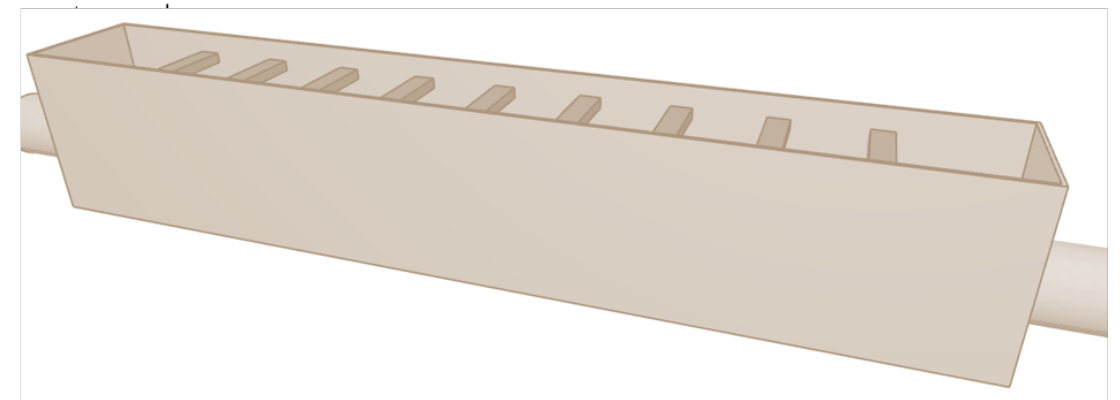

Fonte: Elaboração própria (2020). 
Vale destacar que os metacomponentes dos grupos A e B consideram soluções mais completas dos edifícios metroviários, incorporando elementos aos módulos como, por exemplo, o sistema de ventilação. Como essas edificações possuem um sistema de ventilação bastante complexo e de grandes dimensões, padronizar essa solução e incluí-la no metacomponente reduziria o tempo de discussões e formalizaria a proposta de maior qualidade e eficiência técnica.

\subsubsection{Grupo C - Edificações sobre o solo}

Outro metacomponente da biblioteca é o edifício de salas técnicas, que usualmente se localiza acima do solo no entorno da estação. Esse módulo deve servir como apoio ao desenvolvimento do projeto, podendo sofrer alterações, principalmente no pavimento térreo, em função das características urbanas do local de implantação.

\subsubsection{Grupo D - Setores individualizados}

Neste grupo se concentram os módulos dos setores com funções específicas que podem ser encaixados em diferentes projetos, de acordo com a necessidade de cada estação. São listados abaixo alguns exemplos de possíveis setores de estações que configuram um metacomponente deste grupo:

a) Bloco de salas operacionais;

b) Bloco de sanitários;

c) Acessos - Existem alguns tipos de acessos que foram usados em várias estações de uma linha, como é o caso das cúpulas metálicas com cobertura de vidro, da Linha 5-Lilás. Essa tipologia de acesso pode vir a ser um item da biblioteca.

d) Blocos de salas técnicas - Separados por temas ou por salas, caso não seja possível implantar o edifício como um todo no terreno. 
Nesta configuração, os metacomponentes seriam utilizados no início do projeto, adiantando a etapa da modelagem, e servindo também como um método de conferência das diretrizes de cada área da estação.

A Figura 46 ilustra a estrutura da biblioteca proposta, com a separação dos metacomponentes pelo trecho de implantação ou por setores com funções específicas. A imagem destaca também o módulo desenvolvido na pesquisa.

Figura 46 - Estrutura da biblioteca: exemplo de metacomponenes por grupo

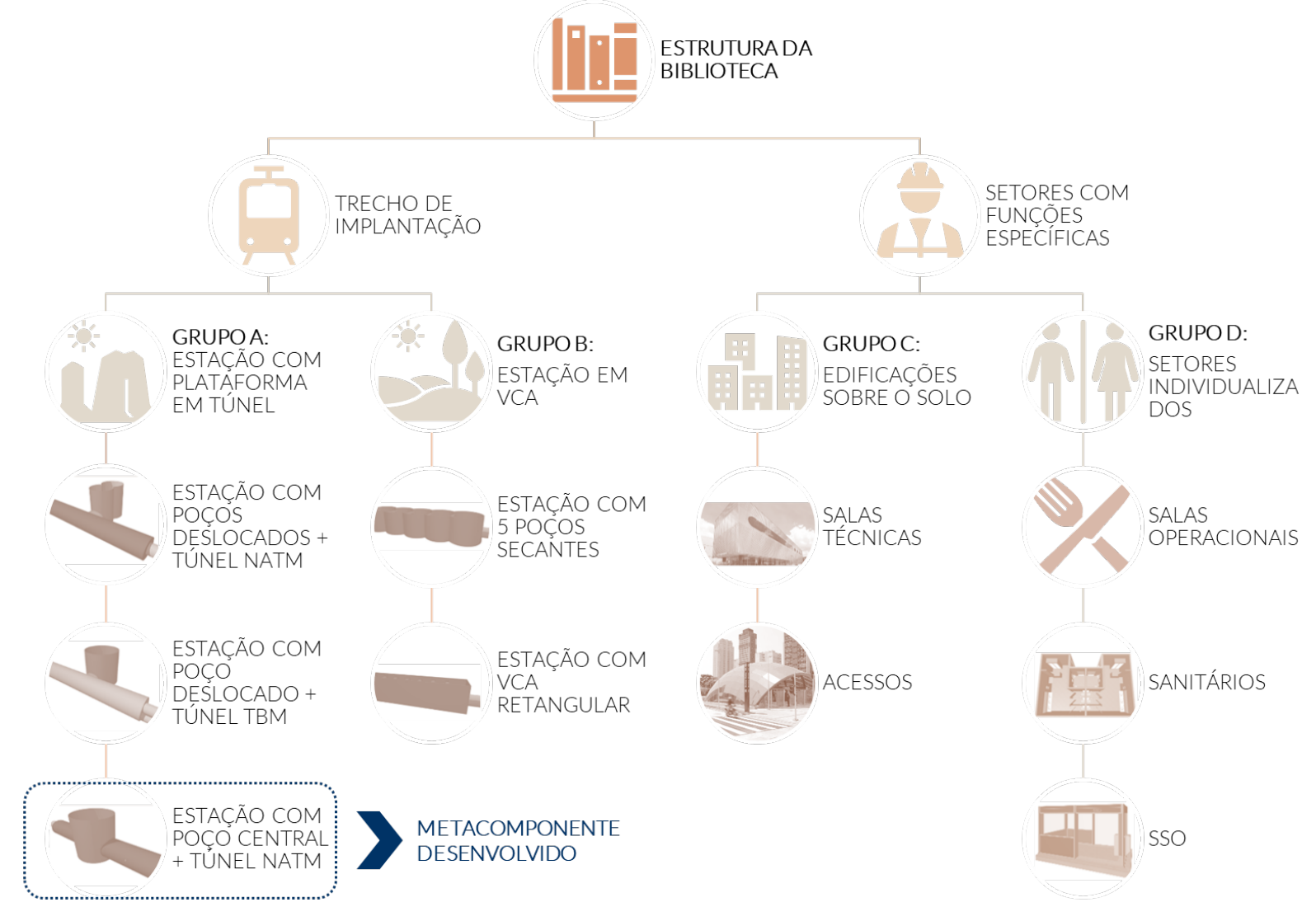

Fonte: Elaboração própria (2021).

\subsection{MODELAGEM DO METACOMPONENTE}

A presente pesquisa desenvolveu um item da biblioteca de metacomponentes BIM para o Metrô/SP, a fim de descrever seu processo e analisar a eficiência do artefato proposto. Neste sentido, este tópico da pesquisa apresenta as características gerais de modelagem do metacomponente desenvolvido. 
O projeto padrão escolhido pertence ao grupo $A$, e corresponde à parte subterrânea de uma estação com plataforma em túnel NATM e poço central. As soluções projetuais são baseadas no projeto da estação Ponte Grande, principalmente em relação à solução de ventilação, disposição do porão de cabos e dimensionamento dos equipamentos técnicos.

O software utilizado para modelagem do metacomponente foi o ArchiCAD, pela liberdade na concepção dos elementos e objetos oferecida pela ferramenta, que facilita a modelagem de projetos fora do padrão da construção civil, como é o caso de estações de metrô, e também pela habilidade e experiência profissional da autora com a ferramenta. Foram utilizadas algumas versões do software, à medida que novas atualizações eram publicadas. As novas versões trouxeram inovações quanto às ferramentas, assim como a possibilidade da criação de propriedades para os materiais de construção.

Os sistemas de classificação ${ }^{19}$ foram utilizados com o objetivo de auxiliar a organização do modelo e, consequentemente, do processo de trabalho. Portanto, conforme preconiza o padrão IFC, todos os objetos do modelo foram classificados segundo o sistema IFC, o padrão do ArchiCAD e outros, criados especificamente para codificar, orçar e inserir as regras do Metrô/SP nos componentes.

O início da modelagem se deu pela definição dos pavimentos e a altura de cada nível. Os níveis criados, correspondentes às estruturas de contenção profunda da estação, são: porão de cabos, canal de ventilação, plataforma, mezanino inferior e mezaninos intermediários. Além de alguns níveis para apoio da modelagem, assim como um nível destinado ao módulo do mezanino intermediário.

A Figura 47 mostra a definição de pisos do metacomponente. Os números assinalados em azul são variáveis, desde que respeitem as regras referentes às escadas e o piso a piso das estações. Os números referentes à elevação de cada piso, assinalados com a cor laranja, serão alterados quando o metacomponente for inserido em um modelo com os demais pavimentos da estação.

\footnotetext{
${ }^{19}$ As ferramentas/funções do ArchiCAD são destacadas no texto com formatação diferente, para fácil identificação.
} 
Figura 47 - Estrutura do arquivo - Definição de pisos

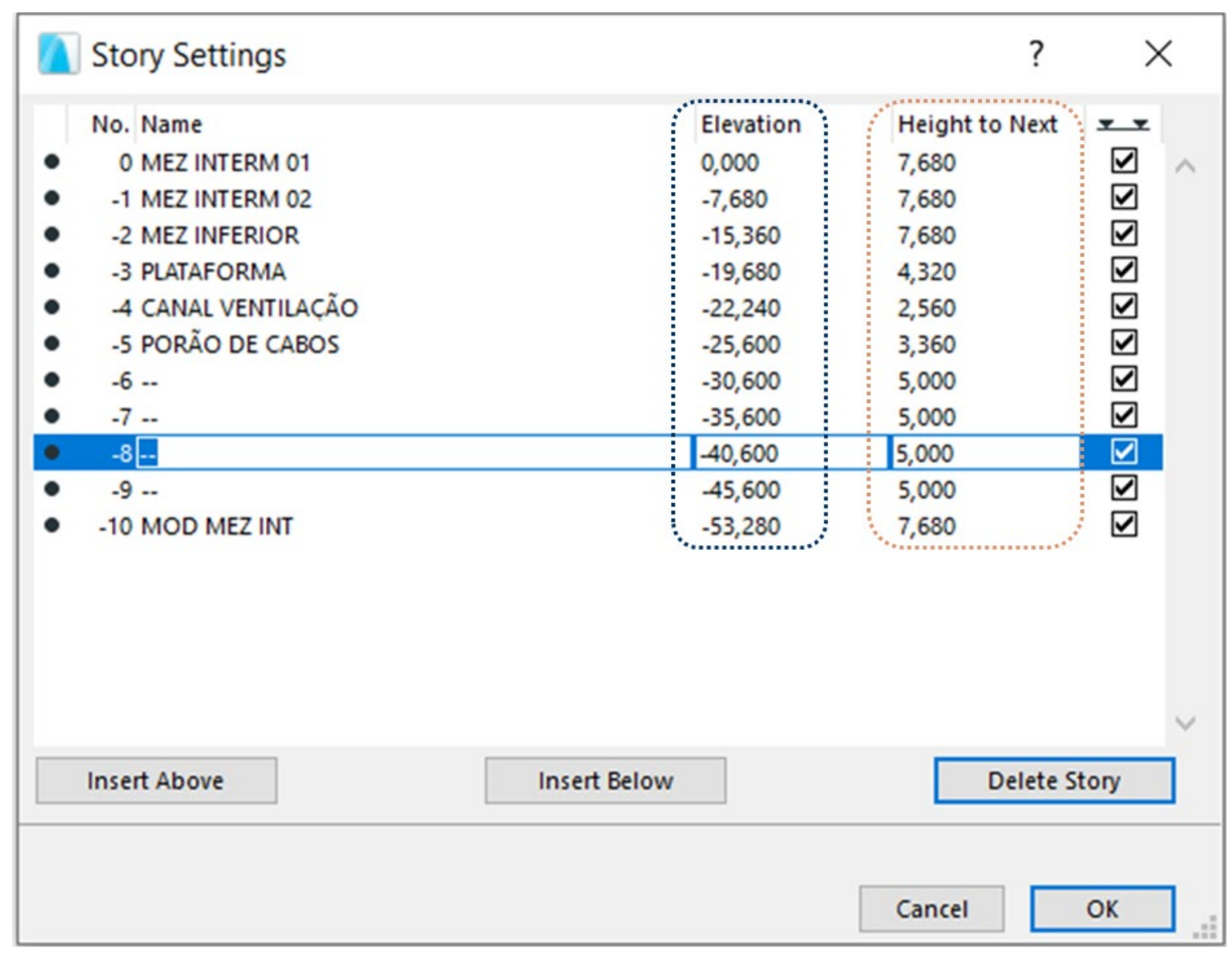

Fonte: Elaboração própria (2020).

Os mezaninos intermediários possuem características iguais, por isso foram considerados como um pavimento tipo. Sendo assim, o pavimento foi modelado fora da régua da estação, no nível -10 . Este nível foi inserido como um módulo nos pavimentos destinados ao mezanino intermediário, conforme demonstra o corte na Figura 48. O número de mezaninos intermediários e a altura de piso a piso desses pavimentos são parâmetros que devem ser ajustados conforme a profundidade da via permanente e a cota do saguão de entrada de cada estação.

Além do ajuste das cotas de elevação, a inserção do metacomponente em um projeto real deve considerar o georreferenciamento da estação. E, a fim de que os modelos das diversas disciplinas tenham a mesma localização espacial, deve ser acrescentado um ponto de referência ao arquivo. 
Figura 48 - Estrutura do arquivo: Inserção do Mezanino intermediário

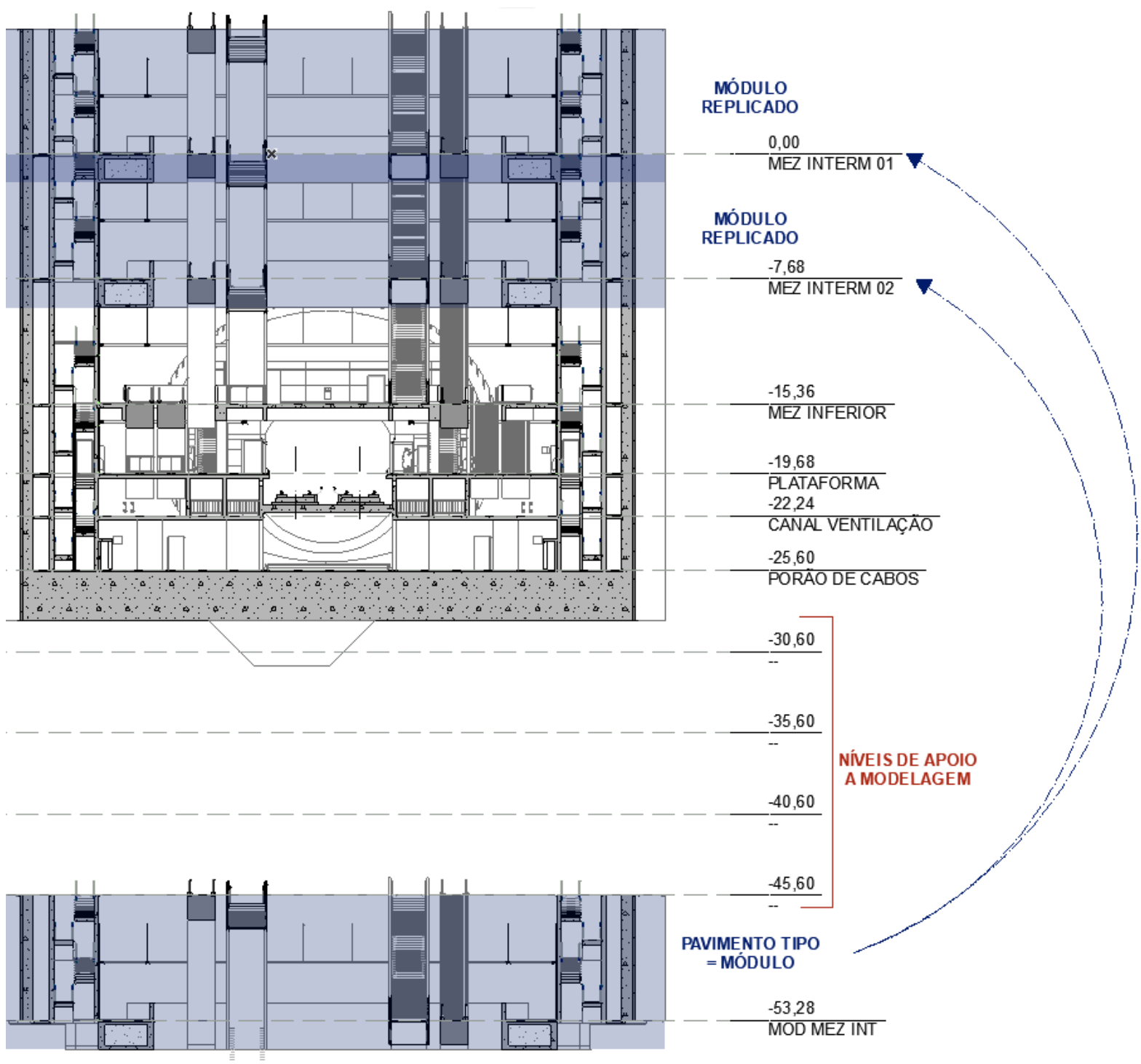

Fonte: Elaboração própria (2020).

\subsubsection{Elementos construtivos}

Em projetos de estações subterrâneas há uma predominância de paredes de concreto, portanto grande parte das paredes que formam o metacomponente são composições de concreto estrutural, com acabamento de verniz incolor (EB 15). As variações se dão na espessura do concreto, e no caso das paredes exteriores, há uma camada de concreto primário. A camada de verniz foi considerada com uma espessura de 0,001 para que não tenha destaque nas peças gráficas, porém no modelo é possível verificar a localização e a geometria desta película. A Figura 49 
apresenta a composição de uma parede de concreto, com pintura de verniz dos dois lados.

Figura 49 - Composição de uma parede de concreto

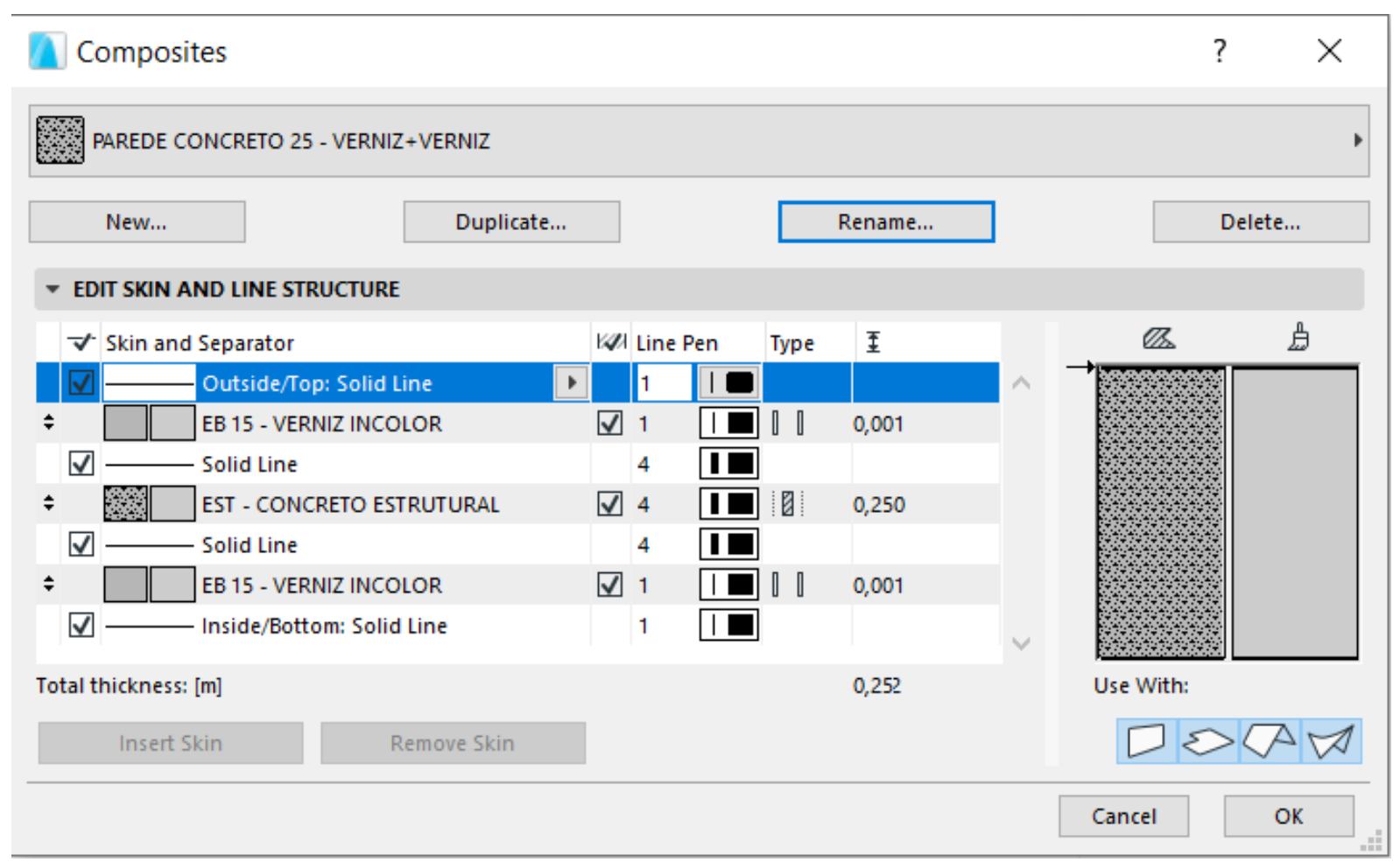

Fonte: Elaboração própria (2020).

Todos os materiais e revestimentos utilizados no modelo são identificados pelo código do Metrô. No caso das paredes e lajes, o código é inserido nos materiais de construção. Posteriormente esses códigos são utilizados para o levantamento de quantidades. Por estarem relacionados a valores de tabelas de referências, a estimativa de orçamento também pode ser emitida através do modelo BIM.

Para quantificar e orçar os elementos construtivos, de acordo com a finalidade proposta do modelo, é necessário inserir os códigos nos materiais de construção e selecionar a composição ideal para cada componente, desta forma não é preciso classificar parede por parede ou laje por laje.

Com relação ao sistema de classificação, as paredes foram categorizadas segundo o sistema original da ferramenta de modelagem e o IFC, sendo "parede" e "ifcWall", respectivamente. 
A altura das paredes está conectada aos pavimentos, para que elas acompanhem as possíveis alterações de piso a piso. A Figura 50 exemplifica como as paredes devem ser modeladas, relacionando sua origem e topo aos pavimentos.

Figura 50 - Modelagem das paredes - Altura

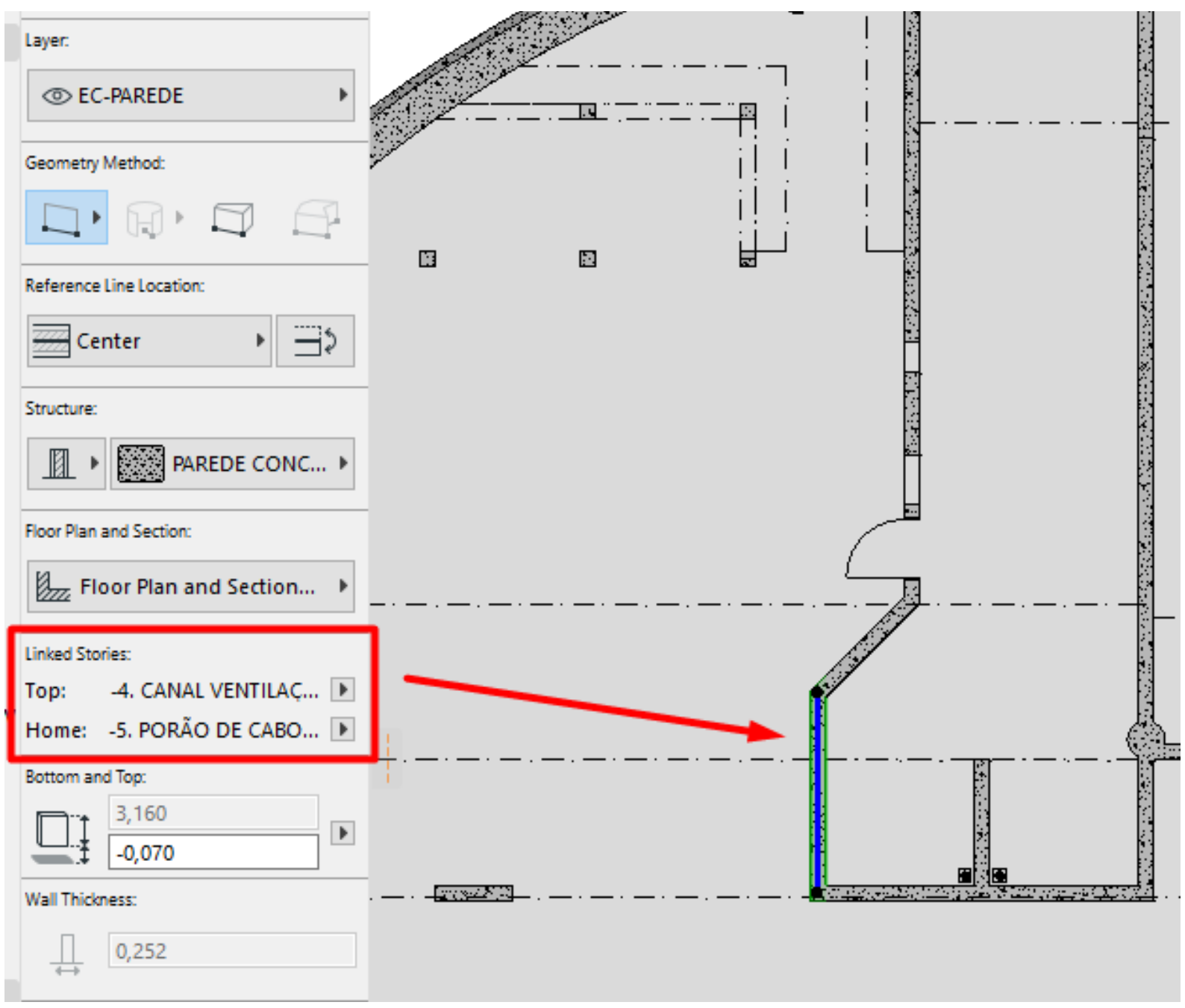

Fonte: Elaboração própria (2020).

As paredes que tem a mesma localização em vários pavimentos são contínuas no modelo, como é o caso das paredes do poço de elevador e dos dutos de ventilação vertical. Desta forma as alterações de posição, referente ao redimensionamento dos espaços, podem ser percebidas em diversos pavimentos.

No caso do mezanino intermediário, como ele é modelado em um piso separado do restante do edifício, as paredes obrigatoriamente são conectadas do piso de origem ao imediatamente superior. 
A intersecção entre as paredes é um desafio importante para parametrização do metacomponente, na medida em que o modelo deve absorver as alterações de dimensionamento sem perder o vínculo entre as linhas de referência das paredes. A Figura 51 apresenta uma imagem com as paredes do poço central desvinculadas, ocasionando erros de representação, orçamentação e no modelo 3D.

Figura 51 - Erros de representação: quebra do vínculo entre as paredes

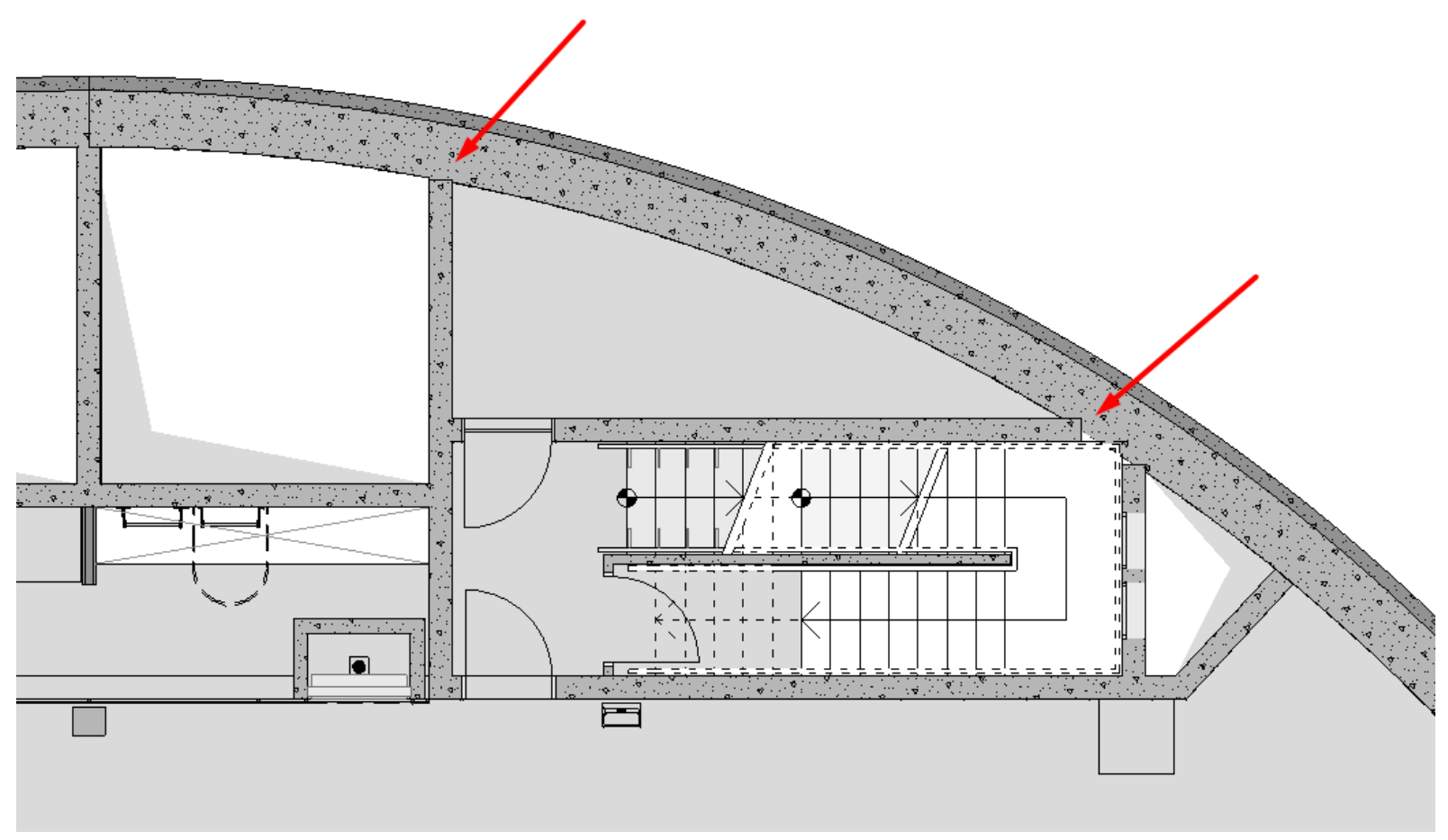

Fonte: Elaboração própria (2020).

Os elementos estruturais devem ser revisados e refinados, caso sejam feitas alterações significativas nas proporções do metacomponente. Por isso é importante que haja parâmetros de ajuste estrutural, e também seja possível separar os itens das diferentes disciplinas no metacomponente, facilitando também a análise e o fluxo de trabalho de cada área. Neste sentido, foi utilizado o recurso dos vegetais/7ayers para separar os elementos estruturais dos de arquitetura, conforme ilustrado na Figura 52. 
Figura 52 - Modelo separados: arquitetura e estrutura

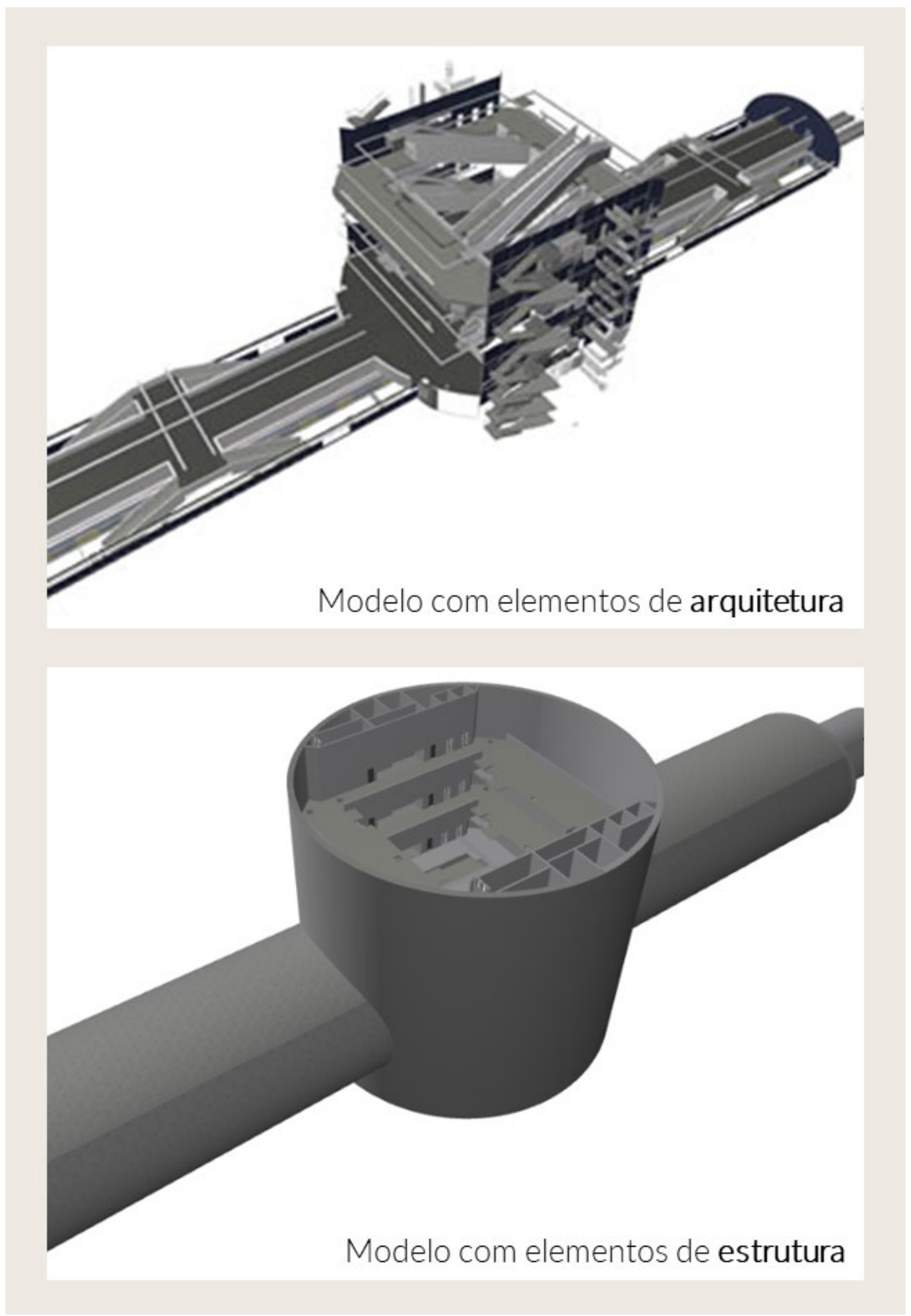

Fonte: Elaboração própria (2020). 
Outro recurso, que pode ser utilizado para separação dos elementos compostos, é a visua7ização da estrutura (Figura 53), que apresenta o modelo somente com os núcleos estruturais, eliminando desta forma os acabamentos, pertencentes à disciplina de arquitetura.

Figura 53 - Recurso para visualização e separação dos itens de estrutura

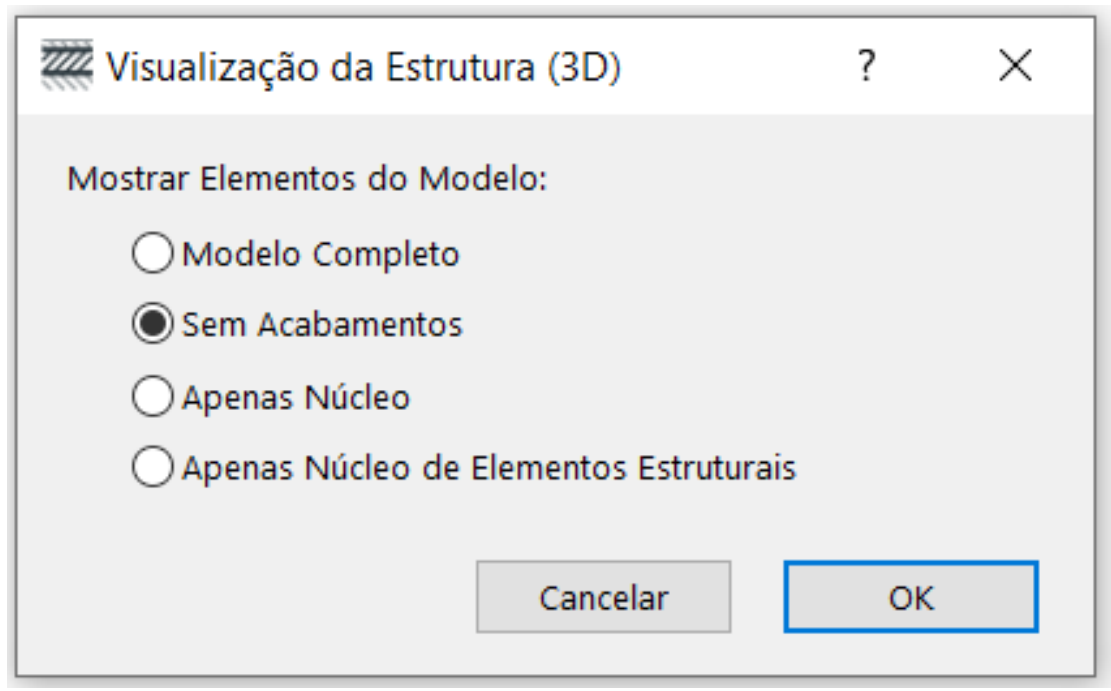

Fonte: Elaboração própria (2020).

As lajes também são modeladas como composições e, no metacomponente em questão, a maioria é formada por acabamentos de granito ou cimentado, além de uma camada de concreto estrutural. O código do Metrô/SP com relação aos acabamentos está situado no material de construção. Os elementos são classificados como "laje" no sistema de classificação original do software, e como "ifcSlab" nas propriedades do IFC.

\subsubsection{Portas e caixilhos}

As portas dos pavimentos são numeradas e identificadas por uma letra correspondente ao seu nível. Por exemplo, no porão de cabos cada porta é nomeada com um " $\mathrm{C}$ " na frente do número. Esta informação deve aparecer nos desenhos técnicos e nas tabelas de quantitativos e orçamentos. No metacomponente essa informação é inserida no marcador dos elementos. 
O tipo de esquadria é indicado conforme as definições da lista de materiais do Metrô/SP, LM-9.00.00.00-3B3-001 (2015). O código especificado e as dimensões dos elementos no modelo traduzem as características de cada componente do projeto. O código referente a lista de materiais é indicado no ID dos elementos e outras informações também podem ser inseridas no próprio componente como, por exemplo, o uso de soleiras ou peitoris associadas àquele caixilho, e informações especificas de outras disciplinas. A Figura 54 mostra um recorte da lista de materiais do Metrô/SP, com as especificações das portas cortafogo mais utilizadas.

Figura 54 - Elementos especiais

\begin{tabular}{|c|c|c|c|c|}
\hline Código & Descrição do Elemento & Un. & Dados Geométricos & Desenho de Referência \\
\hline \multicolumn{5}{|c|}{ ES - ELEMENTOS ESPECIAIS } \\
\hline PCF 01 & $\begin{array}{l}\text { Porta corta-fogo de abrir, } 1 \text { folha - } \\
\text { sem bandeira (Nota 1) }\end{array}$ & un. & L=variável; H=variável & \\
\hline PCF 02 & $\begin{array}{l}\text { Porta corta-fogo de abrir, } 2 \text { folhas - } \\
\text { sem bandeira (Nota 1) }\end{array}$ & un. & L=variável; $\mathrm{H}=$ variável & \\
\hline PCF 03 & $\begin{array}{l}\text { Porta corta-fogo de abrir, } 1 \text { folha - } \\
\text { com bandeira (Nota 1) }\end{array}$ & un. & L=variável; H=variável & \\
\hline PCF 04 & $\begin{array}{l}\text { Porta corta-fogo de abrir, } 2 \text { folhas - } \\
\text { com bandeira (Nota 1) }\end{array}$ & un. & $\mathrm{L}=$ variável; $\mathrm{H}=$ variável & \\
\hline
\end{tabular}

Fonte: Lista de materiais - CMSP (2015).

No caso dos caixilhos e portas é possível criar propriedades para que os componentes indiquem a associação com outros elementos. A Tabela 5 apresenta uma tabela de portas, com as informações necessárias para o projeto básico. As informações são retiradas da geometria do modelo ou de campos específicos como ID, TAG e propriedades dos elementos do metacomponente. O campo na tabela destinado a informações pode ser preenchido pelos projetistas para indicar alguma característica especial.

As tabelas dos elementos, além de serem itens importantes para orçamentação, também podem ser instrumentos para as alterações de projeto no metacomponente. Através dos mapas de caixi 7hos e portas é fácil identificálos e promover alterações. 
Tabela 5 - Tabela de portas do pavimento Porão de Cabos

VÃOS / PORTAS

\begin{tabular}{|c|c|c|c|c|c|}
\hline TAG & ID & DIMENSAO & $\begin{array}{l}\text { PROP. } \\
\text { SOLFIRA }\end{array}$ & & $\begin{array}{l}\text { TEXTO TABELA } \\
\text { OBSERVACÕES }\end{array}$ \\
\hline & & $(\mathrm{L} \times \mathrm{H})$ & & & \\
\hline $\mathrm{C} 01$ & PCF 01/01 & $1,00 \times 2,10$ & Sem soleira & \multirow{2}{*}{ 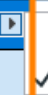 } & \multirow{2}{*}{$\begin{array}{l}\text { EC } 05 \text { - Junta em PVC } \\
\text { EC } 16 \text { - Soleira em granito } \\
\text { Sem soleira }\end{array}$} \\
\hline $\mathrm{C} 02$ & PCF 01/01 & $1,00 \times 2,10$ & Sem soleira & & \\
\hline $\mathrm{C} 03$ & PCF 01/01 & $1,00 \times 2,10$ & Sem soleira & & \\
\hline $\mathrm{CO} 4$ & PCF 01/01 & $1,00 \times 2,10$ & Sem soleira & & \\
\hline $\operatorname{co5}$ & SIS & $1,00 \times 2,10$ & Sem soleira & & FORNECIMENTO VENTILAÇÃO \\
\hline $\mathrm{C} 06$ & SIS & $1,00 \times 2,10$ & Sem soleira & & FORNECIMENTO VENTILAÇÃO \\
\hline $\mathrm{C} 07$ & SIS & $1,00 \times 2,10$ & Sem soleira & & FORNECIMENTO VENTILAÇÃO \\
\hline $\mathrm{C} 08$ & SIS & $1,00 \times 2,10$ & Sem soleira & & FORNECIMENTO VENTILAÇÃO \\
\hline
\end{tabular}

Fonte: Elaboração própria (2020).

Com relação à posição dos caixilhos, é necessário observar que pode acontecer de estarem entre dois pavimentos distintos, como é o caso do mezanino inferior e o intermediário. A Figura 55 e a Figura 56 mostram um exemplo no qual as venezianas de ventilação da escada de emergência estão posicionadas entre dois pavimentos.

Figura 55 - Posição dos caixilhos entre pavimentos

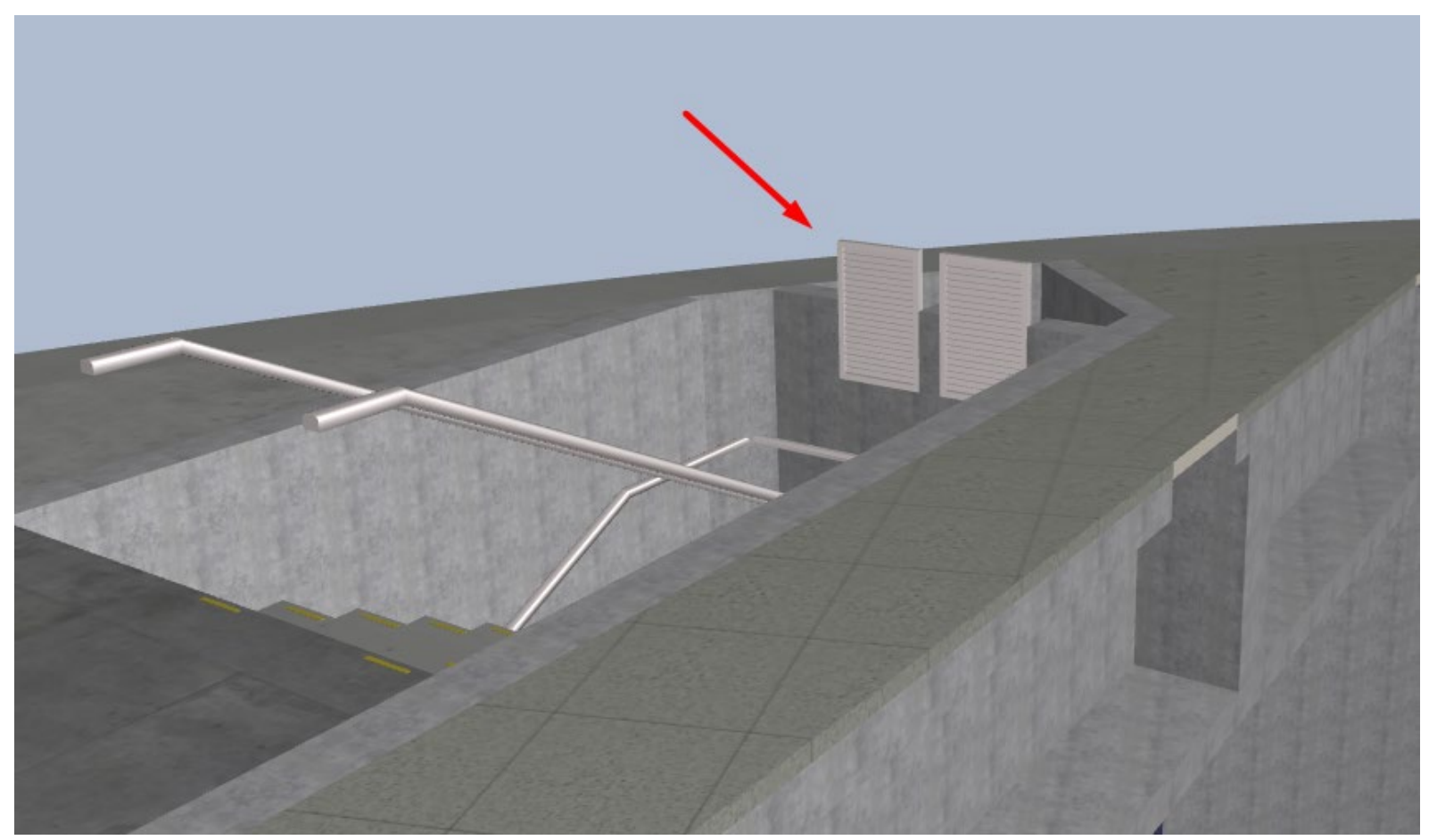

Fonte: Elaboração própria (2020). 
A solução adotada neste caso foi aumentar a altura da parede para que ela "invada" o próximo pavimento, e diminuir a parede do pavimento superior para se adequar a parede com o caixilho. A altura de inserção das venezianas de ventilação das escadas de emergência é estipulada por uma regra de acordo com a altura do patamar da escada.

Figura 56 - Posição dos caixilhos entre pavimentos: solução

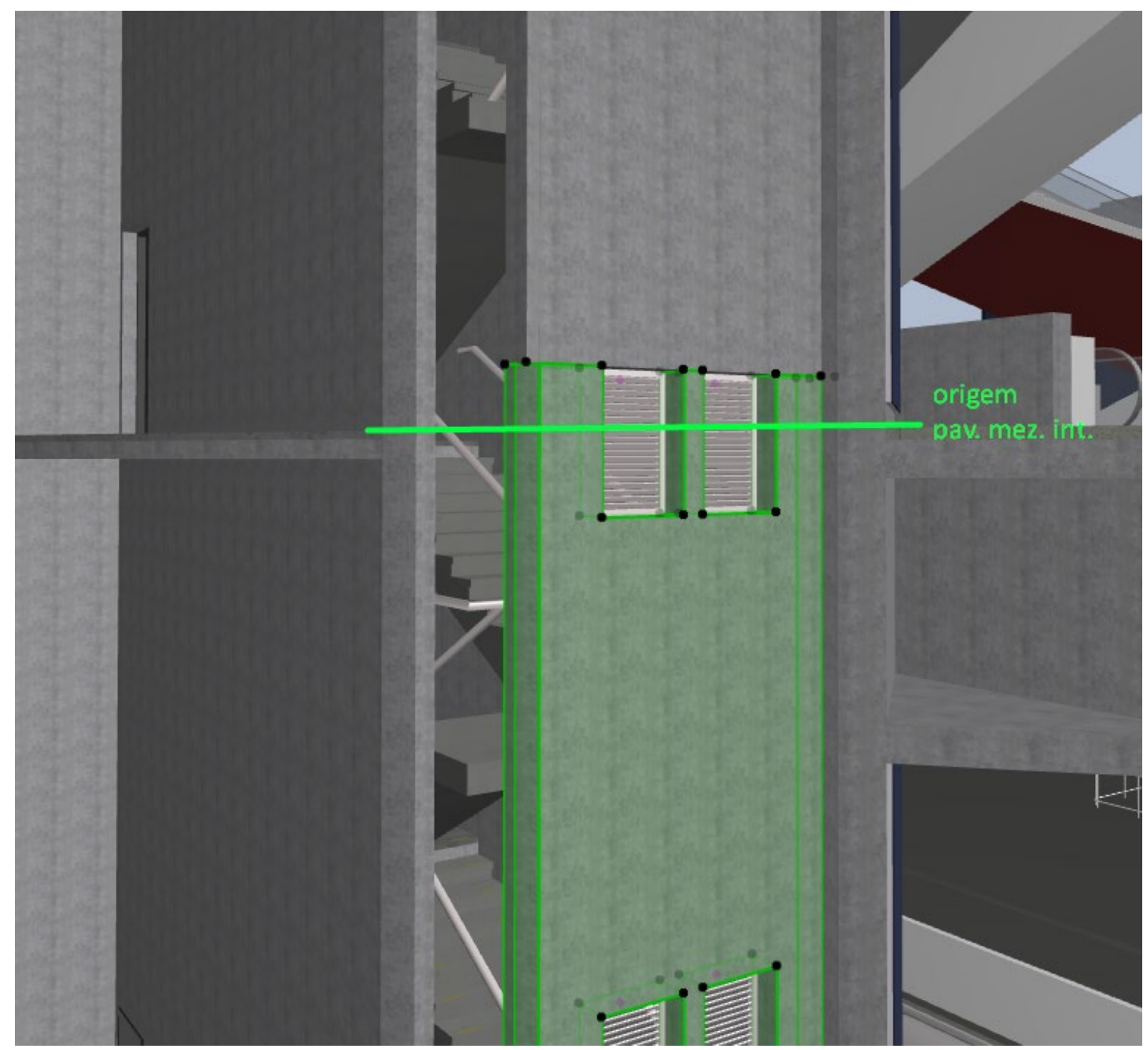

Fonte: Elaboração própria (2020). 


\subsubsection{Escadas e equipamentos}

Os equipamentos de circulação vertical (escadas fixas e rolantes) são locados no piso de origem. Essa é uma definição importante para organização do modelo.

As escadas fixas são constituídas de estrutura e acabamento, que devem ser separados nos modelos das respectivas disciplinas. Portanto, no metacomponente os acabamentos, corrimãos e itens de comunicação visual foram modelados separados da estrutura, e inseridos nos vegetais/7ayers específicos.

Tanto as escadas fixas quanto as rolantes são outro desafio especial para parametrização do metacomponente, pois seu dimensionamento deve estar relacionado à altura de piso a piso do projeto e ao tamanho do poço central. Pensando na relação entra a altura da escada e do piso a piso, as escadas foram vinculadas ao topo e origem dos respectivos pavimentos.

A classificação das escadas foi feita de acordo com o sistema do software utilizado, podendo classificar as partes da escada separadamente. Conforme exemplificado na Figura 57, a classificação da estrutura da escada é diferente da categorização do seu acabamento. Nas propriedades IFC, acabamento e estrutura são classificados como "ifcStair". A identificação das escadas é atribuída no campo ID, com o prefixo "EF" para as escadas fixas mais o número correspondente, e "ER" para as escadas rolantes.

Os equipamentos e o mobiliário da estação são objetos modelados de acordo com as características dos PP's. Estes devem ser homologados pelo Metrô/SP, quanto às suas características. Esses elementos possuem três classificações no metacomponente:

f) Classificação original do software: mobiliário/furniture

a) Classificação IFC: ifcFurnishingElement

b) Classificação CMSP: criada para designar os elementos específicos do Metrô/SP, dando a possibilidade de direcionar regras e outras propriedades a esses elementos. A Figura 58 apresenta um exemplo de classificação de uma escada marinheiro, com uma regra específica direcionada a ela. 
Figura 57 - Classificação e características das escadas fixas

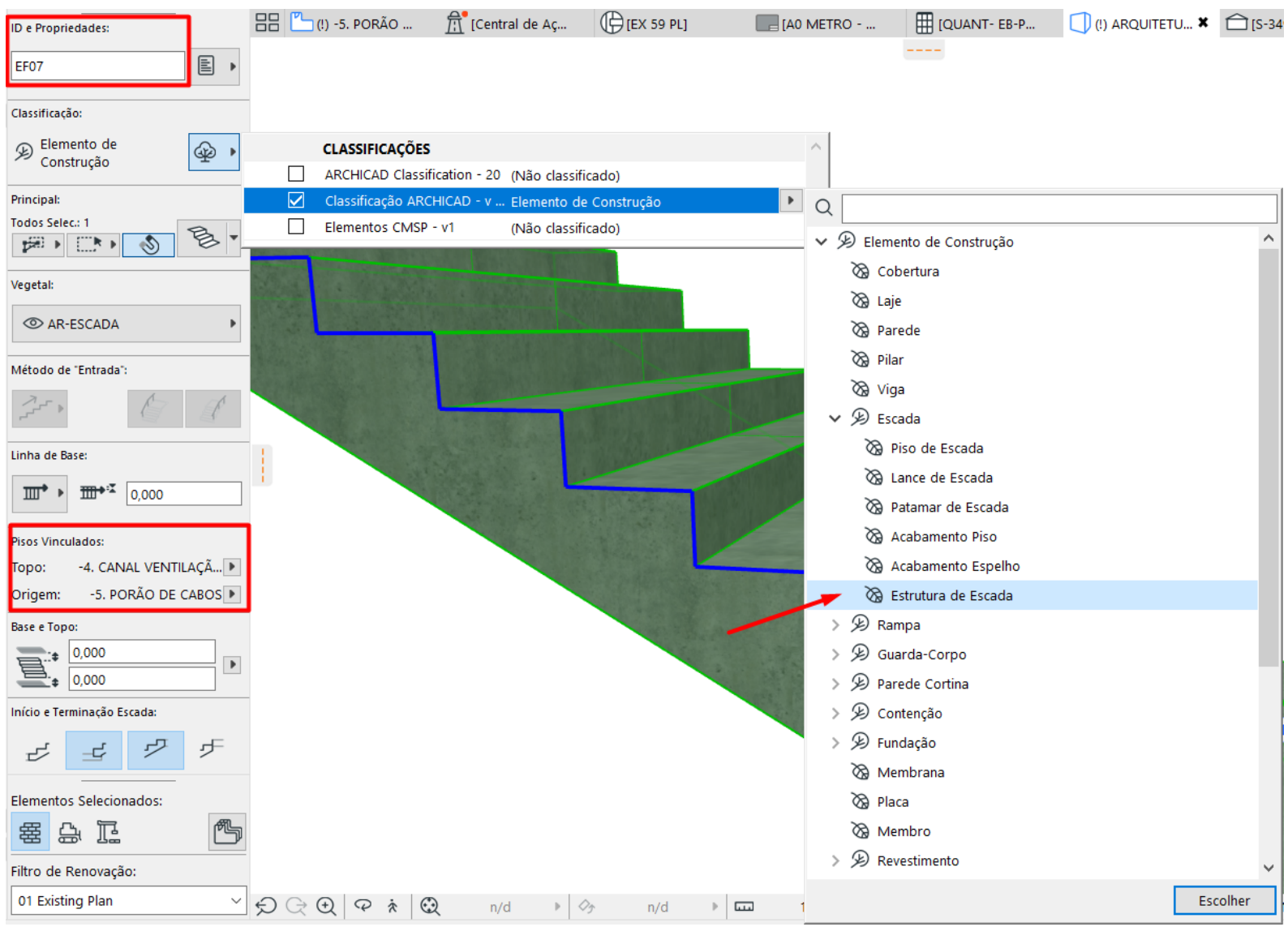

Fonte: Elaboração própria (2020).

Figura 58 - Classificação e características dos equipamentos

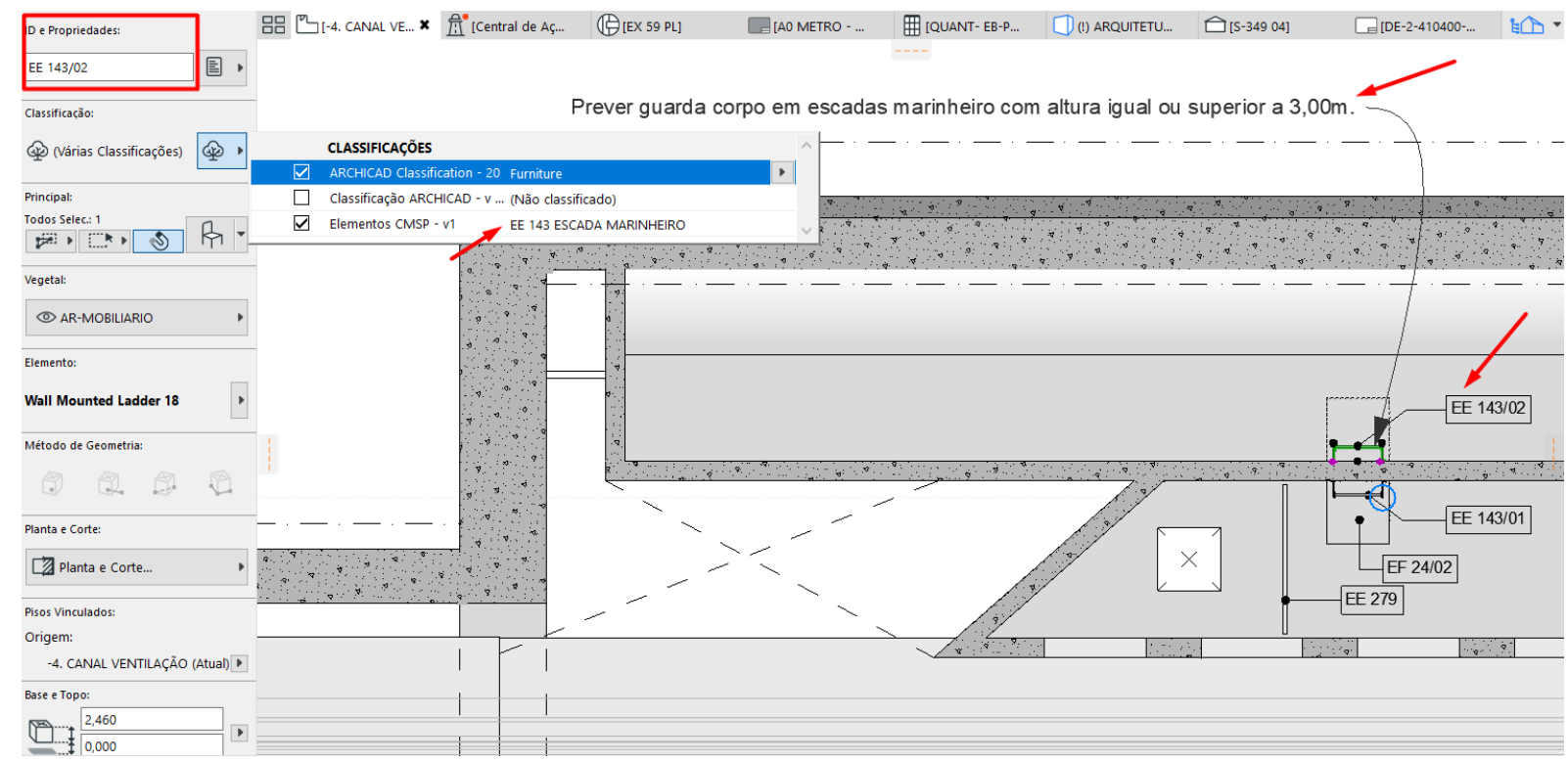

Fonte: Elaboração própria (2020). 
Os equipamentos possuem também propriedades específicas que indicam informações importantes do componente. Por exemplo: os dados geométricos, o número relativo ao projeto padrão do Metrô/SP, as regras de alerta para os projetistas inerentes ao objeto, e os dados para orçamentação.

Esses dados irão compor o orçamento da estação, que servirá de base para a licitação do projeto. A Figura 59 apresenta as propriedades do componente EE 143/02 - Escada marinheiro.

Figura 59 - Classificação e características dos equipamentos

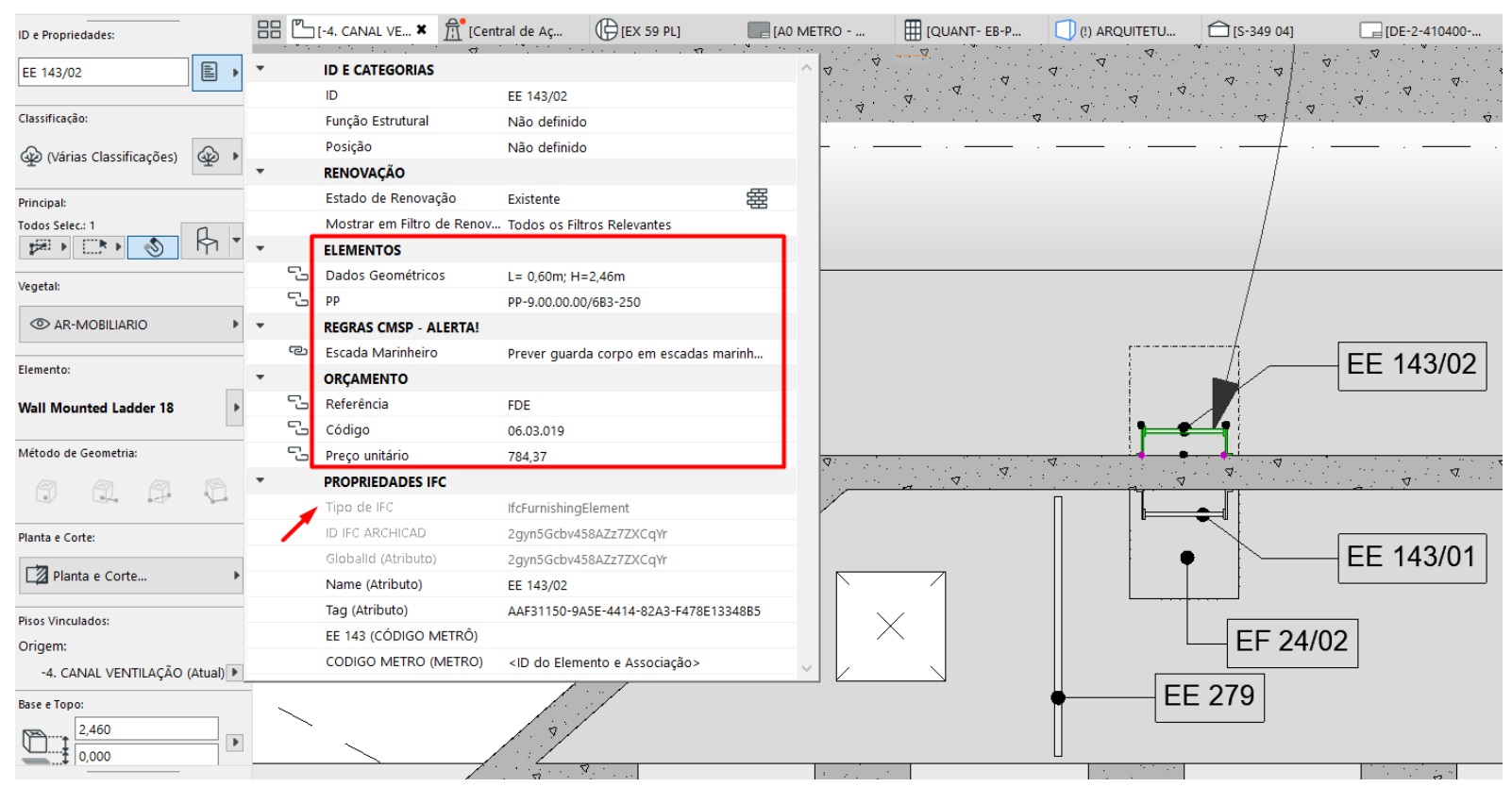

Fonte: Elaboração própria (2020). 


\subsubsection{Espaços}

Outro mapa importante do metacomponente é a "Tabela de ambientes", que lista as características de cada lugar, conforme ilustrado da Tabela 6 Grande parte das informações dessa tabela são retiradas do elemento zona.

Tabela 6 - Tabela de ambientes

TABELA DE AMBIENTES

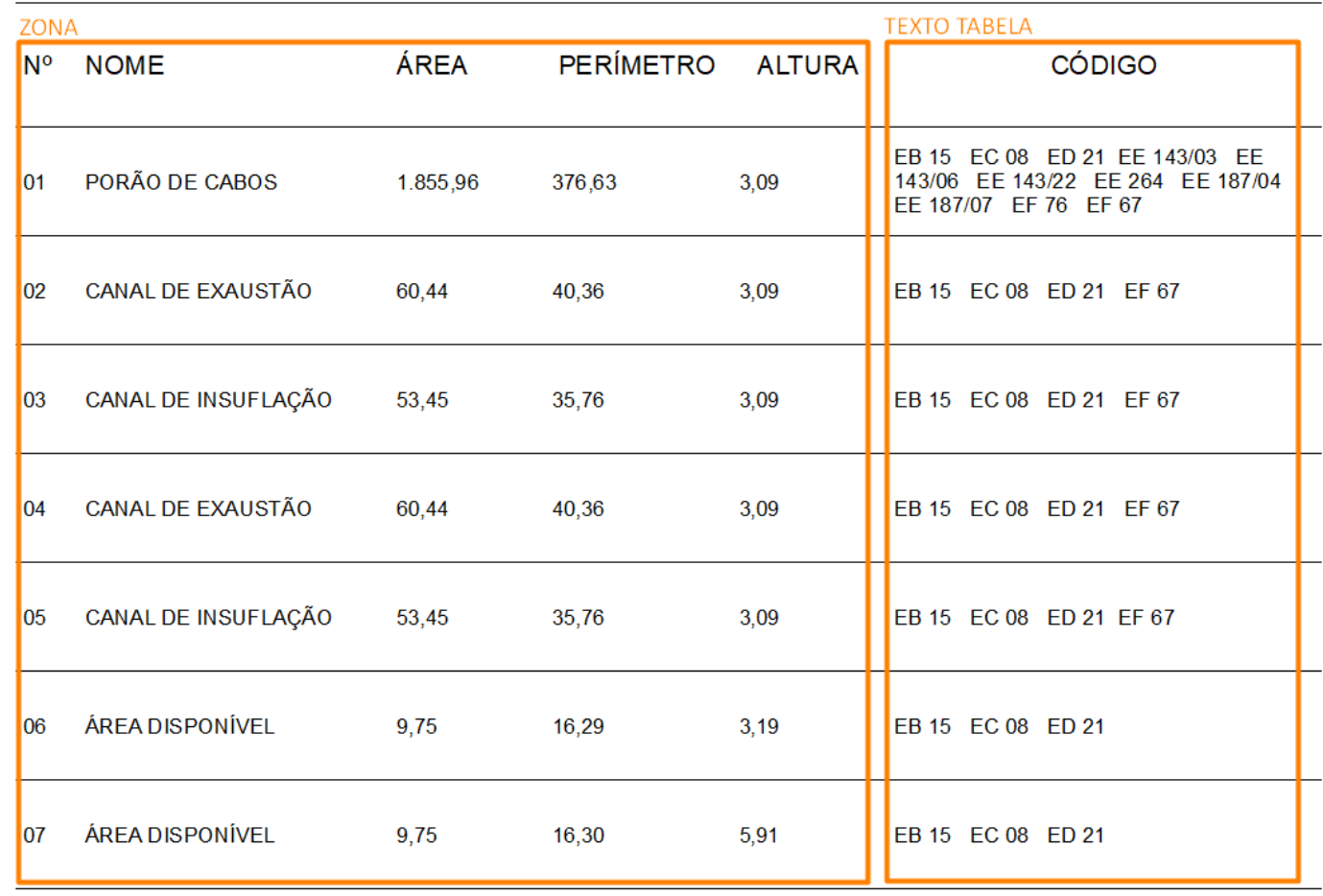

Fonte: Elaboração própria (2020).

\subsection{REGRAS}

As premissas e instruções de projeto do Metrô/SP comunicam diretrizes e informações sobre projetos e obras acumuladas ao longo da história da companhia. Portanto, é importante que a biblioteca proposta absorva esse conhecimento e disponibilize-o de forma simples e prática aos projetistas e analistas. A modelagem do projeto padrão considera os documentos técnicos e introduz tais premissas nos componentes do modelo. Cada regra é aplicada ao e7emento, materia 7 ou espaço específico, promovendo um processo de trabalho mais ágil, à medida que não é necessário consultar ou saber todas as instruções para aplicá-las. 
Além de auxiliar no desenvolvimento dos metacomponentes, as regras devem balizar as alterações dos projetos padrão, na adaptação do mesmo a diferentes terrenos e demandas. As premissas de projeto estabelecem os acabamentos dos espaços técnicos e operacionais, disponibilizando também algumas opções de materiais mais utilizados nas edificações já construídas.

A partir do estudo das instruções IP-9.00.00.00-3B2-001, IC9.00.00.00/3B3-001 e IC-9.00.00.00/3B3-002, que auxiliam no desenvolvimento dos projetos básicos das estações, foram estabelecidos três critérios para a classificação das regras: aplicação, tipo e localização. Essa separação organiza as regras em grupos para sua utilização no desenvolvimento do metacomponente.

O campo "aplicação" define em qual ferramenta ou elemento a regra deve ser atribuída, como por exemplo, no componente "barra de apoio" a restrição para o uso exclusivo de perfil tubular de aço inox deve aparecer. Já o critério "tipo" determina qual é a natureza da regra, se é uma norma, definição, opções de materiais e acabamentos ou um alerta para determinado uso ou situação padrão.A "localização" define qual é a área de abrangência da instrução dentro da estação, podendo excluir determinadas regras para este estudo, como é o caso das premissas direcionadas às áreas externas ou descobertas das estações. O Quadro 10 apresenta os grupos, com a descrição da classificação proposta.

Quadro 10 - Classificação das regras do Metrô/SP

APLICAÇÃO

\begin{tabular}{ll}
\hline Regra & Descrição \\
\hline Materiais & Se refere a regras direcionadas aos materiais utilizados nas estações. Deve ser \\
& aplicada nos materiais de construção dos metacomponentes, com a finalidade de \\
& instruir e alertar o uso dos materiais, além de oferecer opções para a seleção \\
& características dos acabamentos.
\end{tabular}

Elementos Esse tipo de regra será aplicado em elementos específicos do modelo, como por exemplo as escadas, piso tátil, painel de revestimento, etc.

Caixilhos

São as regras direcionadas as ferramentas utilizadas para modelar aberturas e caixilhos. 
Portas São as regras direcionadas as ferramentas utilizadas para modelar portas.

TIPO

\begin{tabular}{|c|c|}
\hline Regra & Descrição \\
\hline Norma & Refere-se a uma norma, que deve ser verificada para aplicação no projeto. \\
\hline Alerta & $\begin{array}{l}\text { É uma regra de alerta para determinado uso ou situação padrão, a ser considerada } \\
\text { em caso de alterações do metacomponente. }\end{array}$ \\
\hline Opção & $\begin{array}{l}\text { A regra descreve um ou mais campos que devem ser aplicados em elementos ou } \\
\text { materiais, para que o usuário possa adicionar uma descrição ou selecionar uma } \\
\text { opção. }\end{array}$ \\
\hline Definição & $\begin{array}{l}\text { É uma premissa que estabelece a condição de determinado elemento ou ambiente. } \\
\text { Essas diretrizes são aplicadas diretamente no metacomponente. }\end{array}$ \\
\hline
\end{tabular}

LOCALIZAÇÃO

\begin{tabular}{ll} 
Regra & Descrição \\
\hline Geral & Regras aplicadas em todas as áreas da estação. \\
\hline Área pública & $\begin{array}{l}\text { São as regras direcionadas as áreas de deslocamentos e espera dos passageiros. } \\
\text { No caso dos metacomponentes de contenção profunda, essa área consiste nos } \\
\text { locais de encaminhamento dos passageiros desde os mezaninos intermediários até } \\
\text { a plataforma. }\end{array}$
\end{tabular}

Área restrita Regras destinadas as áreas exclusivas de funcionários, voltadas as partes técnicas e operacionais da estação.

Área externa / As regras pertencentes a este grupo são para as partes externas e descobertas descoberta das estações. Portanto, não interferem nos metacomponentes de contenção profunda.

Sanitário I Instruções específicas para sanitários e vestiários, tanto públicos quanto exclusivos Vestiário para funcionários.

Fonte: Elaboração própria (2020). 
O resultado dessa classificação sobre as premissas de projeto é apresentado no Quadro 11, que disponibiliza apenas os itens que foram aplicados no desenvolvimento do metacomponente, ou seja, regras referentes às estruturas de contenção profunda. Excluindo-se, portanto, as instruções específicas para as áreas externas, sanitários/vestiários, saguão de entrada, acessos e edifício de salas técnicas.

Quadro 11 - Regras do Metrô/SP utilizadas no desenvolvimento do metacomponente

\begin{tabular}{|c|c|c|c|c|}
\hline & REGRA & CLASSIF. & & \\
\hline & Descrição & Aplicação & $\begin{array}{l}\text { Tipo de } \\
\text { regra }\end{array}$ & Localização \\
\hline 01 & $\begin{array}{l}\text { Não revestir estruturas de concreto com placas } \\
\text { cerâmicas assentadas. }\end{array}$ & $\begin{array}{l}\text { Material: } \\
\text { Concreto }\end{array}$ & Alerta! & Geral \\
\hline 02 & $\begin{array}{l}\text { Não utilizar placas de gesso acartonado nas áreas } \\
\text { públicas. }\end{array}$ & Material: Gesso & Alerta! & Área Pública \\
\hline 03 & $\begin{array}{l}\text { Os materiais utilizados deverão atender a norma } \\
\text { NBR9442 ou ASTM E } 162 \text { - Índice de propagação } \\
\text { superficial da chama }<20 \text {, na classe A }\end{array}$ & Material: geral & Norma & Geral \\
\hline 04 & $\begin{array}{l}\text { Os materiais utilizados deverão atender a norma } \\
\text { ASTM E } 162 \text { - Densidade ótica específica de } \\
\text { fumaça > } 300\end{array}$ & Material: geral & Norma & Geral \\
\hline 05 & $\begin{array}{l}\text { Os materiais utilizados deverão atender a norma } \\
\text { ASTM D 5865, com relação ao poder calorífico do } \\
\text { material. }\end{array}$ & Material: geral & Norma & Geral \\
\hline 06 & $\begin{array}{l}\text { Todos os materiais deverão ser incombustíveis e, } \\
\text { na queima, não exalar gases tóxicos. }\end{array}$ & Material: geral & Alerta! & Geral \\
\hline 07 & $\begin{array}{l}\text { Os elementos de alumínio devem ser: anodizados } \\
\text { (acabamento semi fosco) ou com pintura } \\
\text { eletrostática }\end{array}$ & $\begin{array}{l}\text { Material: } \\
\text { alumínio }\end{array}$ & Opção & Geral \\
\hline 08 & $\begin{array}{l}\text { Os elementos de aço carbono devem ser: } \\
\text { galvanizados ou com pintura contra corrosão. }\end{array}$ & $\begin{array}{l}\text { Material: aço } \\
\text { Carbono }\end{array}$ & Opção & Geral \\
\hline
\end{tabular}




\begin{tabular}{|c|c|c|c|c|}
\hline & REGRA & CLASSIF. & & \\
\hline & Descrição & Aplicação & $\begin{array}{l}\text { Tipo de } \\
\text { regra }\end{array}$ & Localização \\
\hline 09 & $\begin{array}{l}\text { Elementos de aço inoxidável devem ter } \\
\text { acabamento escovado ST. }\end{array}$ & $\begin{array}{l}\text { Material: Aço } \\
\text { inoxidável }\end{array}$ & Definição & Geral \\
\hline 10 & $\begin{array}{l}\text { Não devem ser usadas chapas metálicas } \\
\text { perfuradas como revestimento nas áreas públicas } \\
\text { ao alcance de pessoas. }\end{array}$ & $\begin{array}{l}\text { Material: Aço } \\
\text { inoxidável }\end{array}$ & Alerta! & Área Pública \\
\hline 11 & $\begin{array}{l}\text { Deve ser previsto perfil de aço carbono embutido } \\
\text { nos cantos vivos das paredes com acabamento } \\
\text { em pintura sobre argamassa. }\end{array}$ & $\begin{array}{l}\text { Material: } \\
\text { pintura }\end{array}$ & Definição & Geral \\
\hline 12 & $\begin{array}{l}\text { Estruturas de concreto aparente devem ser } \\
\text { pintadas com verniz incolor ou revestidas, apenas } \\
\text { nas faces voltadas para área interna da estação. }\end{array}$ & $\begin{array}{l}\text { Material } \\
\text { Concreto }\end{array}$ & Definição & Geral \\
\hline 13 & Utilizar preferencialmente tinta acrílica. & $\begin{array}{l}\text { Material: } \\
\text { Pintura }\end{array}$ & Alerta! & Geral \\
\hline 14 & $\begin{array}{l}\text { Deverá ser previsto perfil de aço carbono em furos } \\
\text { da laje ou nas extremidades livres onde o } \\
\text { acabamento for cimentado desempenado comum. }\end{array}$ & $\begin{array}{l}\text { Material: } \\
\text { cimentado } \\
\text { desempenado }\end{array}$ & Definição & $\begin{array}{l}\text { Área } \\
\text { Restrita }\end{array}$ \\
\hline 15 & $\begin{array}{l}\text { Prever guarda corpo em escadas marinheiro com } \\
\text { altura igual ou superior a } 3,00 \mathrm{~m} \text {. }\end{array}$ & $\begin{array}{l}\text { Elemento: } \\
\text { Escada } \\
\text { marinheiro }\end{array}$ & Definição & $\begin{array}{l}\text { Área } \\
\text { Restrita }\end{array}$ \\
\hline 16 & $\begin{array}{l}\text { Garantir vão livre de } 2,10 \mathrm{~m} \text { sob o guarda-corpo } \\
\text { das escadas marinheiro. }\end{array}$ & $\begin{array}{l}\text { Elemento: } \\
\text { Escada } \\
\text { marinheiro }\end{array}$ & Definição & $\begin{array}{l}\text { Área } \\
\text { Restrita }\end{array}$ \\
\hline 17 & $\begin{array}{l}\text { Os painéis de revestimento (chapa de aço, } \\
\text { cerâmica, laminado estrutural decorativo, alumínio } \\
\text { composto) aplicados junto à faixa de sinalização } \\
\text { de embarque da plataforma devem ser modulados } \\
\text { em função dos elementos de comunicação visual. }\end{array}$ & $\begin{array}{l}\text { Elemento: } \\
\text { painel de } \\
\text { revestimento }\end{array}$ & Opção & Área Pública \\
\hline 18 & Prever piso tátil junto às escadas fixas. & $\begin{array}{l}\text { Elemento: } \\
\text { escada fixa }\end{array}$ & Definição & Geral \\
\hline
\end{tabular}




\begin{tabular}{|c|c|c|c|c|}
\hline & REGRA & CLASSIF. & & \\
\hline & Descrição & Aplicação & $\begin{array}{l}\text { Tipo de } \\
\text { regra }\end{array}$ & Localização \\
\hline 19 & $\begin{array}{l}\text { O envidraçamento de caixas de escadas deve ser } \\
\text { em vidro aramado (NBR 7199). }\end{array}$ & $\begin{array}{l}\text { Elemento: } \\
\text { escada }\end{array}$ & Norma & Geral \\
\hline 20 & $\begin{array}{l}\text { Todas alvenarias de áreas públicas devem ser } \\
\text { pintadas ou revestidas e protegidas com rodapé. }\end{array}$ & $\begin{array}{l}\text { Elemento: } \\
\text { parede }\end{array}$ & Definição & Área Pública \\
\hline 21 & $\begin{array}{l}\text { Prever um console para mapas táteis por } \\
\text { plataforma, próximo à porta de acesso preferencial } \\
\text { de pessoa com deficiência e direcionamento tátil. }\end{array}$ & $\begin{array}{l}\text { Elemento: piso } \\
\text { tátil }\end{array}$ & Alerta! & Área Pública \\
\hline 22 & $\begin{array}{l}\text { Prever espelho na cabeceira das plataformas (um } \\
\text { para cada via). }\end{array}$ & Elemento: zona & Alerta! & Área Pública \\
\hline 23 & $\begin{array}{l}\text { Na ausência das Salas de Ferramentas } \\
\text { Operacionais no nível da plataforma, deve ser } \\
\text { previsto um armário para guarda de equipamentos } \\
\text { de resgate na via e socorro (maca, EPI e outros), } \\
\text { em cada uma delas. }\end{array}$ & Elemento: zona & Definição & Área Pública \\
\hline 24 & $\begin{array}{l}\text { Garantir altura mínima de } 2,40 \mathrm{~m} \text { sob qualquer } \\
\text { elemento de comunicação visual, iluminação ou } \\
\text { som. }\end{array}$ & Elemento: zona & Alerta! & Área Pública \\
\hline 25 & $\begin{array}{l}\text { As plataformas laterais deverão ter largura mínima, } \\
\text { medidas a partir da borda da plataforma, de } 5,00 \mathrm{~m} \\
\text { para estações tipo e } 6,00 \mathrm{~m} \text { para as estações de } \\
\text { integração. }\end{array}$ & Elemento: zona & Alerta! & Área Pública \\
\hline 26 & $\begin{array}{l}\text { A capacidade dos corredores deverá ser calculada } \\
\text { em pessoas por hora pico (php) por canal de } \\
\text { circulação com } 0,60 \mathrm{~m} \text { de largura (can). Cálculo: } \\
1.800 \text { phd x can (até } 4 \% \text { de inclinação) }\end{array}$ & Elemento: zona & Definição & Área Pública \\
\hline 27 & $\begin{array}{l}\text { Espaço livre mínimo na plataforma } 2,50 \mathrm{~m} \text { da borda } \\
\text { da plataforma. Pilares ou obstáculos de dimensões } \\
\text { reduzidas que invadam a plataforma devem estar } \\
\text { locados após } 2,50 \mathrm{~m} \text {. }\end{array}$ & Elemento: pilar & Alerta! & Área Pública \\
\hline
\end{tabular}




\begin{tabular}{|c|c|c|c|c|}
\hline & REGRA & CLASSIF. & & \\
\hline & Descrição & Aplicação & $\begin{array}{l}\text { Tipo de } \\
\text { regra }\end{array}$ & Localização \\
\hline 28 & $\begin{array}{l}\text { Todos os ambientes públicos internos das } \\
\text { estações devem ser revestidos com placas de } \\
\text { granito levigado. }\end{array}$ & Elemento: piso & Definição & Área Pública \\
\hline 29 & $\begin{array}{l}\text { Os alçapões das áreas públicas devem ser } \\
\text { revestidos com o mesmo material de acabamento } \\
\text { do piso no qual estão inseridos. }\end{array}$ & $\begin{array}{l}\text { Elemento: } \\
\text { alçapão }\end{array}$ & Definição & Área Pública \\
\hline 30 & $\begin{array}{l}\text { As escadas fixas das estações devem ser } \\
\text { revestidas com placas de granito apicoado ou } \\
\text { flameado. }\end{array}$ & $\begin{array}{l}\text { Elemento: } \\
\text { escada }\end{array}$ & Opção & Geral \\
\hline 31 & $\begin{array}{l}\text { Os pisos táteis das áreas públicas internas } \\
\text { deverão ser de porcelanato embutidos no piso. }\end{array}$ & $\begin{array}{l}\text { Elemento: piso } \\
\text { tátil }\end{array}$ & Definição & Área Pública \\
\hline 32 & $\begin{array}{l}\text { A cor definida para os pisos táteis de todo o } \\
\text { sistema metroviário é o azul Munsell 10B 5/10. }\end{array}$ & $\begin{array}{l}\text { Elemento: piso } \\
\text { tátil }\end{array}$ & Definição & Área Pública \\
\hline 33 & $\begin{array}{l}\text { A cor definida para a faixa tátil na borda da } \\
\text { plataforma é o amarelo Munsell 2,5Y 8/12. }\end{array}$ & $\begin{array}{l}\text { Elemento: piso } \\
\text { tátil }\end{array}$ & Definição & Área Pública \\
\hline 34 & $\begin{array}{l}\text { Deverá ser previsto direcionamento tátil no piso } \\
\text { das áreas públicas de forma a encaminhar a } \\
\text { pessoa com deficiência desde a rua até a segunda } \\
\text { porta do primeiro carro em cada plataforma (de } \\
\text { cada via), passando pela linha de bloqueio. }\end{array}$ & $\begin{array}{l}\text { Elemento: piso } \\
\text { tátil }\end{array}$ & Alerta! & Área Pública \\
\hline 35 & $\begin{array}{l}\text { Os pisos devem se direcionar sempre para os } \\
\text { elevadores - nunca para escadas fixas ou rolantes. } \\
\text { O encaminhamento para os elevadores deve } \\
\text { direcionar o usuário em direção à botoeira, } \\
\text { geralmente no lado direito da porta do elevador. } \\
\text { Quando houver mais de um elevador, o piso tátil } \\
\text { deve direcionar para ambos os equipamentos. }\end{array}$ & $\begin{array}{l}\text { Elemento: piso } \\
\text { tátil }\end{array}$ & Alerta! & Área Pública \\
\hline 36 & $\begin{array}{l}\text { Os pisos táteis direcional devem ser instalados } \\
\text { próximos ao eixo dos corredores e a no mínimo } \\
1,00 \mathrm{~m} \text { de paredes e obstáculos conforme NBR }\end{array}$ & $\begin{array}{l}\text { Elemento: piso } \\
\text { tátil }\end{array}$ & Norma & Área Pública \\
\hline
\end{tabular}




\begin{tabular}{|c|c|c|c|c|}
\hline & REGRA & CLASSIF. & & \\
\hline & Descrição & Aplicação & $\begin{array}{l}\text { Tipo de } \\
\text { regra }\end{array}$ & Localização \\
\hline & $\begin{array}{l}\text { 9050. Conflito com IC-9-000000-3B3-002: } \\
\text { distância mínima de paredes e obstáculos } 60 \mathrm{~cm} \text {. }\end{array}$ & & & \\
\hline 37 & $\begin{array}{l}\text { Verificar existência de piso tátil de alerta no } \\
\text { entorno de elementos suspensos, guichês, } \\
\text { bilheterias e demais obstáculos. }\end{array}$ & $\begin{array}{l}\text { Elemento: piso } \\
\text { tátil }\end{array}$ & Alerta! & Área Pública \\
\hline 38 & $\begin{array}{l}\text { Deverão ser previstos rodapés em todas as } \\
\text { paredes de alvenarias, inclusive sóculos, com } \\
\text { altura mínima de } 10 \mathrm{~cm} \text {. }\end{array}$ & $\begin{array}{l}\text { Elemento: } \\
\text { parede }\end{array}$ & Alerta! & Geral \\
\hline 39 & Devem ser previstos ralos junto a todos hidrantes. & $\begin{array}{l}\text { Elemento: } \\
\text { hidrante }\end{array}$ & Alerta! & Geral \\
\hline 40 & $\begin{array}{l}\text { Devem ser previstos ralos junto a todas as } \\
\text { torneiras de lavagem. }\end{array}$ & $\begin{array}{l}\text { Elemento: } \\
\text { torneira de } \\
\text { lavagem }\end{array}$ & Alerta! & Geral \\
\hline 41 & $\begin{array}{l}\text { Nas áreas públicas a altura dos forros suspensos } \\
\text { deve garantir um pé direito mínimo de } 3,50 \mathrm{~m} \text {. }\end{array}$ & Elemento: forro & Alerta! & Área Pública \\
\hline 42 & $\begin{array}{l}\text { Quando houver laje no mezanino inferior sobre a } \\
\text { via não instalar forro ou prever forro baffle ou } \\
\text { similar para possibilitar acantonamento de fumaça. }\end{array}$ & Elemento: forro & Alerta! & Área Pública \\
\hline 43 & $\begin{array}{l}\text { Para as áreas públicas, os corrimãos deverão ser } \\
\text { de aço inox }\end{array}$ & $\begin{array}{l}\text { Elemento: } \\
\text { guarda-corpo }\end{array}$ & Definição & Área Pública \\
\hline 44 & $\begin{array}{l}\text { Nos locais em que forem instalados guarda-corpos } \\
\text { ou corrimãos isolados deverá ser construída } \\
\text { mureta de alvenaria ou concreto para fixação dos } \\
\text { montantes, com altura mínima de } 12 \mathrm{~cm} \text { e largura } \\
\text { de } 20 \mathrm{~cm} \text {. }\end{array}$ & $\begin{array}{l}\text { Elemento: } \\
\text { guarda-corpo }\end{array}$ & Alerta! & Geral \\
\hline
\end{tabular}




\begin{tabular}{|c|c|c|c|c|}
\hline & REGRA & CLASSIF. & & \\
\hline & Descrição & Aplicação & $\begin{array}{l}\text { Tipo de } \\
\text { regra }\end{array}$ & Localização \\
\hline 45 & $\begin{array}{l}\text { Nas passarelas das vias e nas salas técnicas, } \\
\text { deverá ser previsto guarda-corpo específico da } \\
\text { Lista Geral de Elementos de Acabamento e de } \\
\text { Comunicação Visual (LM-9.00.00.00/3B3-001). }\end{array}$ & $\begin{array}{l}\text { Elemento: } \\
\text { guarda-corpo }\end{array}$ & Definição & $\begin{array}{l}\text { Área } \\
\text { Restrita }\end{array}$ \\
\hline 46 & $\begin{array}{l}\text { No interior das estações, as escadas e rampas } \\
\text { com largura maior que } 2,40 \mathrm{~m} \text { deverão ter } \\
\text { corrimãos intermediários }\end{array}$ & $\begin{array}{l}\text { Elemento: } \\
\text { escada }\end{array}$ & Alerta! & Geral \\
\hline 47 & $\begin{array}{l}\text { Largura útil mínima de } 1,20 \mathrm{~m} \text { para escadas e } \\
\text { rampas de uso restrito, conforme NBR } 9050 .\end{array}$ & $\begin{array}{l}\text { Elemento: } \\
\text { escada }\end{array}$ & Norma & Geral \\
\hline 48 & $\begin{array}{l}\text { Deverá ser verificada a necessidade de } \\
\text { fechamento complementar nas laterais e entre as } \\
\text { escadas, fixas e rolantes. }\end{array}$ & $\begin{array}{l}\text { Elemento: } \\
\text { escada }\end{array}$ & Alerta! & Área Pública \\
\hline 49 & $\begin{array}{l}\text { Prever fechamento total dos vãos sob escadas } \\
\text { fixas e rolantes das áreas públicas das estações, } \\
\text { ou na área de projeção horizontal das mesmas, } \\
\text { onde a altura livre seja inferior a } 2,10 \mathrm{~m} \text {. }\end{array}$ & $\begin{array}{l}\text { Elemento: } \\
\text { escada }\end{array}$ & Alerta! & Área Pública \\
\hline 50 & $\begin{array}{l}\text { Nas extremidades das escadas e rampas deverão } \\
\text { ser previstos espaços de acomodação com } \\
\text { comprimento mínimo de } 1,5 \text { vezes a largura do } \\
\text { conjunto de escadas e/ou rampas. }\end{array}$ & $\begin{array}{l}\text { Elemento: } \\
\text { escada }\end{array}$ & Alerta! & Área Pública \\
\hline 51 & $\begin{array}{l}\text { A capacidade das escadas fixas deverá ser } \\
\text { calculada em pessoas por hora pico (php) por } \\
\text { canal de circulação em } 0,60 \mathrm{~m} \text { de largura (can). } \\
\text { Cálculo: } 1.300 \text { phd x can }\end{array}$ & $\begin{array}{l}\text { Elemento: } \\
\text { escada }\end{array}$ & Definição & Área Pública \\
\hline 52 & $\begin{array}{l}\text { Escadas fixas para uso público deverão ter largura } \\
\text { livre mínima de } 1,80 \mathrm{~m} \text {. A largura deve ser, } \\
\text { preferencialmente, número múltiplo de } 0,60 \mathrm{~m} \text {. }\end{array}$ & $\begin{array}{l}\text { Elemento: } \\
\text { escada }\end{array}$ & Definição & Área Pública \\
\hline
\end{tabular}




\begin{tabular}{|c|c|c|c|c|}
\hline & REGRA & CLASSIF. & & \\
\hline & Descrição & Aplicação & $\begin{array}{l}\text { Tipo de } \\
\text { regra }\end{array}$ & Localização \\
\hline 53 & $\begin{array}{l}\text { Cada lance das escadas fixas, para uso público ou } \\
\text { restrito, não poderá exceder a 3,0m de desnível. }\end{array}$ & $\begin{array}{l}\text { Elemento: } \\
\text { escada }\end{array}$ & Alerta! & Área Pública \\
\hline 54 & $\begin{array}{l}\text { As escadas fixas deverão estar em conformidade } \\
\text { com a norma técnica NBR } 9077 \text { e, quando } \\
\text { associadas à escada rolante, ter inclinação de } 30^{\circ} \text {. }\end{array}$ & $\begin{array}{l}\text { Elemento: } \\
\text { escada }\end{array}$ & Norma & Área Pública \\
\hline 55 & $\begin{array}{l}\text { A capacidade das escadas rolantes deverá ser } \\
\text { calculada em pessoas por hora pico (php) por } \\
\text { canal de circulação em 0,60m de largura (can). } \\
\text { Cálculo: } 6.000 p h d x \text { can }\end{array}$ & $\begin{array}{l}\text { Elemento: } \\
\text { escada rolante }\end{array}$ & Definição & Área Pública \\
\hline 56 & $\begin{array}{l}\text { As dimensões das escadas rolantes deverão } \\
\text { seguir o documento IP-9.00.00.00/3Z0-004 }\end{array}$ & $\begin{array}{l}\text { Elemento: } \\
\text { escada rolante }\end{array}$ & Norma & Área Pública \\
\hline 57 & $\begin{array}{l}\text { Deverá ser previsto, para cada escada rolante, } \\
\text { nicho para quadro de controle das escadas } \\
\text { rolantes (QCER), preferencialmente, nas } \\
\text { proximidades da cabeceira superior de cada } \\
\text { escada, com visada direta para a mesma. }\end{array}$ & $\begin{array}{l}\text { Elemento: } \\
\text { escada rolante }\end{array}$ & Alerta! & Área Pública \\
\hline 58 & $\begin{array}{l}\text { Devem ser previstas lixeiras de aço inox a cada } \\
10 \mathrm{~m} \text {, aproximadamente. }\end{array}$ & $\begin{array}{l}\text { Elemento: } \\
\text { lixeira }\end{array}$ & Alerta! & Área Pública \\
\hline 59 & $\begin{array}{l}\text { Nas plataformas, deverão ser previstas lixeiras } \\
\text { transparentes, de acrílico. }\end{array}$ & $\begin{array}{l}\text { Elemento: } \\
\text { lixeira }\end{array}$ & Alerta! & Área Pública \\
\hline 60 & $\begin{array}{l}\text { Devem ser previstos dois armários para SPAP, } \\
\text { telefone técnico e de emergência por plataforma, } \\
\text { posicionados um na cabeceira e o outro a dois } \\
\text { terços, aproximadamente, do armário da } \\
\text { cabeceira. }\end{array}$ & $\begin{array}{l}\text { Elemento: } \\
\text { equipamento }\end{array}$ & Alerta! & Área Pública \\
\hline 61 & $\begin{array}{l}\text { Os bancos devem ser dispostos em conjuntos de, } \\
\text { no mínimo, quatro assentos, mais um assento } \\
\text { especial para obesos, nas extremidades das } \\
\text { plataformas, fixados de preferência à parede para }\end{array}$ & $\begin{array}{l}\text { Elemento: } \\
\text { banco }\end{array}$ & Alerta! & Área Pública \\
\hline
\end{tabular}




\begin{tabular}{|c|c|c|c|c|}
\hline & REGRA & CLASSIF. & & \\
\hline & Descrição & Aplicação & $\begin{array}{l}\text { Tipo de } \\
\text { regra }\end{array}$ & Localização \\
\hline & facilitar a limpeza. & & & \\
\hline 62 & $\begin{array}{l}\text { Nas esquadrias em geral utilizar alumínio } \\
\text { anodizado, acabamento fosco acetinado. }\end{array}$ & $\begin{array}{l}\text { Aberturas e } \\
\text { caixilhos }\end{array}$ & Definição & Geral \\
\hline 63 & $\begin{array}{l}\text { Nas áreas técnicas e operacionais utilizar portas } \\
\text { de alumínio do tipo venezianas com ventilação } \\
\text { permanente. }\end{array}$ & Porta & Definição & $\begin{array}{l}\text { Área } \\
\text { Restrita }\end{array}$ \\
\hline 64 & $\begin{array}{l}\text { Corta-fogo: antecâmaras de escadas } \\
\text { enclausuradas, rotas de fuga, rotas } \\
\text { especializadas, salas com carga de incêndio } \\
\text { elevadas, etc. }\end{array}$ & Porta & Definição & Geral \\
\hline 65 & $\begin{array}{l}\text { Utilizar porta estanque em salas de baterias e } \\
\text { dutos de ventilação. }\end{array}$ & Porta & Definição & $\begin{array}{l}\text { Área } \\
\text { Restrita }\end{array}$ \\
\hline 66 & $\begin{array}{l}\text { Todas as portas de saída de emergência devem } \\
\text { abrir no sentido da rota de fuga, sem obstruir a } \\
\text { passagem de pessoas ou diminuir o vão livre do } \\
\text { corredor. }\end{array}$ & Porta & Alerta! & Geral \\
\hline
\end{tabular}

Fonte: Elaboração própria (2020).

As regras apresentadas acima foram introduzidas de diversas formas no metacomponente. As que possuem o tipo "definição" foram utilizadas para o desenvolvimento do modelo, sendo aplicada no momento da modelagem. Já as regras de "alerta" e "norma" foram mantidas no modelo para balizar futuras alterações.

O campo "aplicação" determinou as ferramentas nas quais as regras foram inseridas. As informações relativas aos acabamentos foram disponibilizadas no modelo através do atributo material de construção. Foram criadas propriedades e classificações específicas para informar as regras e os 
dados de orçamentação de cada produto. Portanto, quando cada material é utilizado suas informações são incluídas no modelo.

A Figura 60 apresenta as configurações do materia 7 de construção "EB 02 - AZULEJO", no qual é possível verificar o nome do acabamento, no campo ID o código da CMSP, a descrição do produto conforme a lista de materiais do Metrô/SP (LM-9.00.00.00-3B3-001), a classificação do material, as informações para orçamentação e as regras relativas ao revestimento.

Figura 60 - Configuração do material EB 02

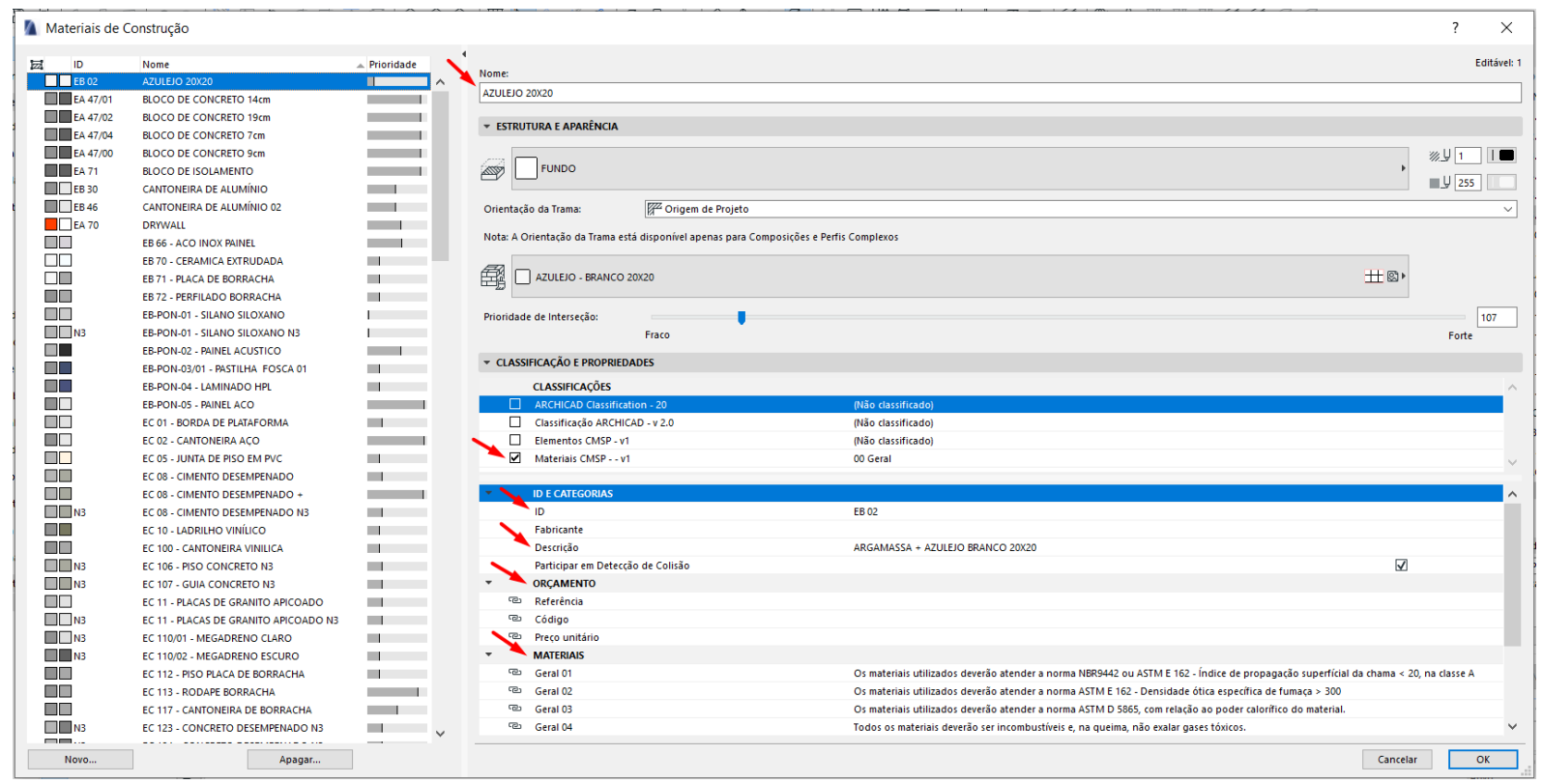

Fonte: Elaboração própria (2020).

A aplicação das regras nos elementos construtivos foi viabilizada através do sistema de classificação, que permite identificar e criar propriedades para elementos específicos. Foi desenvolvido um grupo de propriedades chamado "REGRAS CMSP" destinado a abrigar os alertas sobre as características dos elementos construtivos.

Além de identificar o elemento, a classificação e suas propriedades podem ser utilizadas na extração do orçamento e na documentação do projeto. É importante classificar corretamente cada componente, porque ele pode ser constituído de elementos diferentes do seu significado real, como é o caso dos 
pisos táteis, que são construídos com a ferramenta 7aje, mas na realidade são elementos de comunicação visual, conforme é ilustrado na Figura 61.

Figura 61 - Classificação dos componentes: exemplo piso tátil

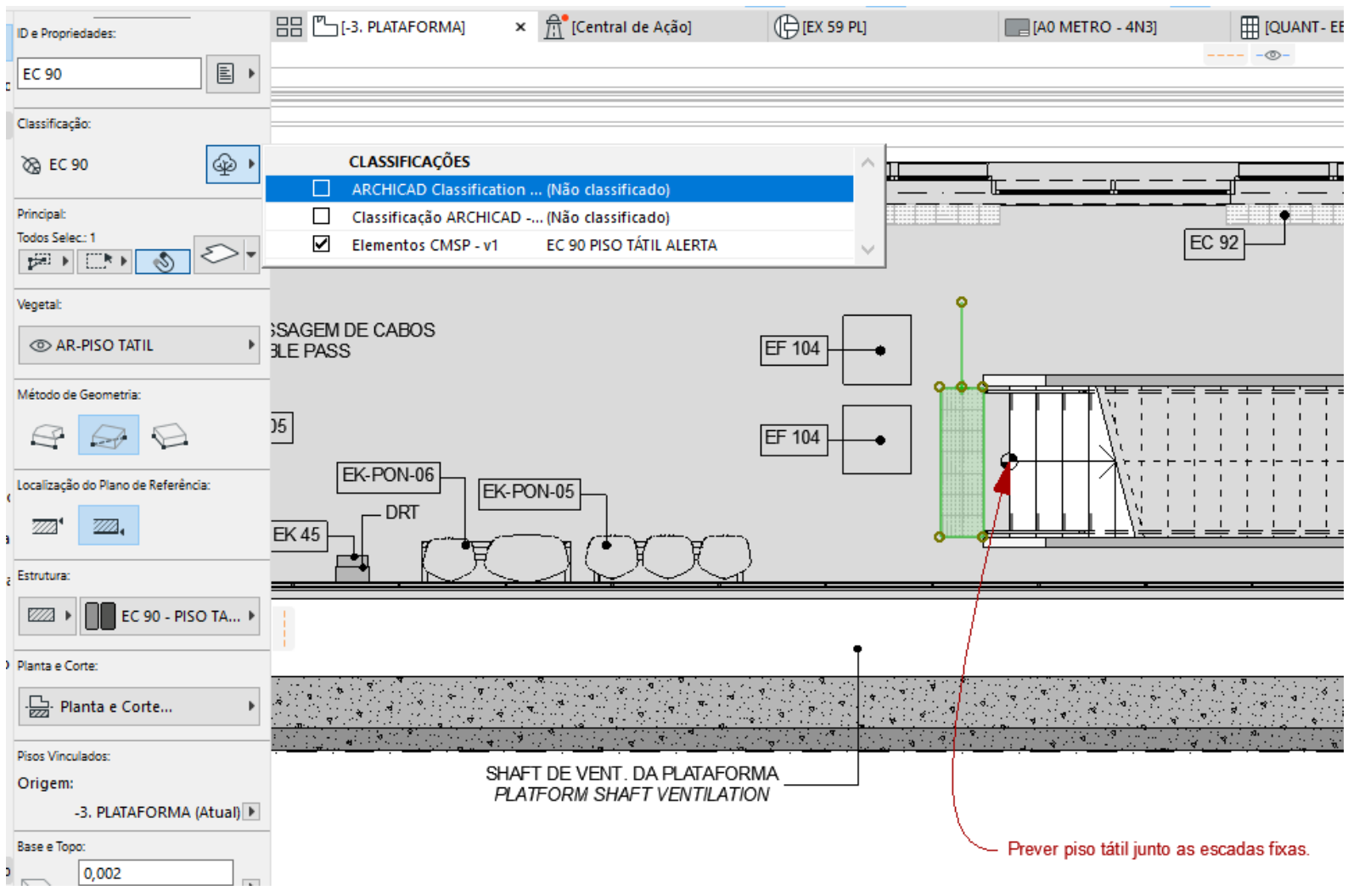

Fonte: Elaboração própria (2020).

Ao usar as classificações, é possível destinar características e regras para elementos específicos e não para uma categoria de elementos. Após classificar e aplicar as regras nos elementos foram criadas vistas das plantas com todas as regras expostas para conferência, conforme demonstrado na Figura 62. O conjunto de regras para determinada situação, material ou elemento também pode ser filtrado em tabelas específicas.

A inclusão das premissas e instruções do Metrô/SP nos itens da biblioteca, além de disponibilizar um registro atualizado e de fácil utilização das regras aos analistas e projetistas, orienta alguns parâmetros para alteração do metacomponente, conforme será apresentado no item 4.4 - Parâmetros. 
Figura 62 - Plataforma: exposição das regras de alerta e norma

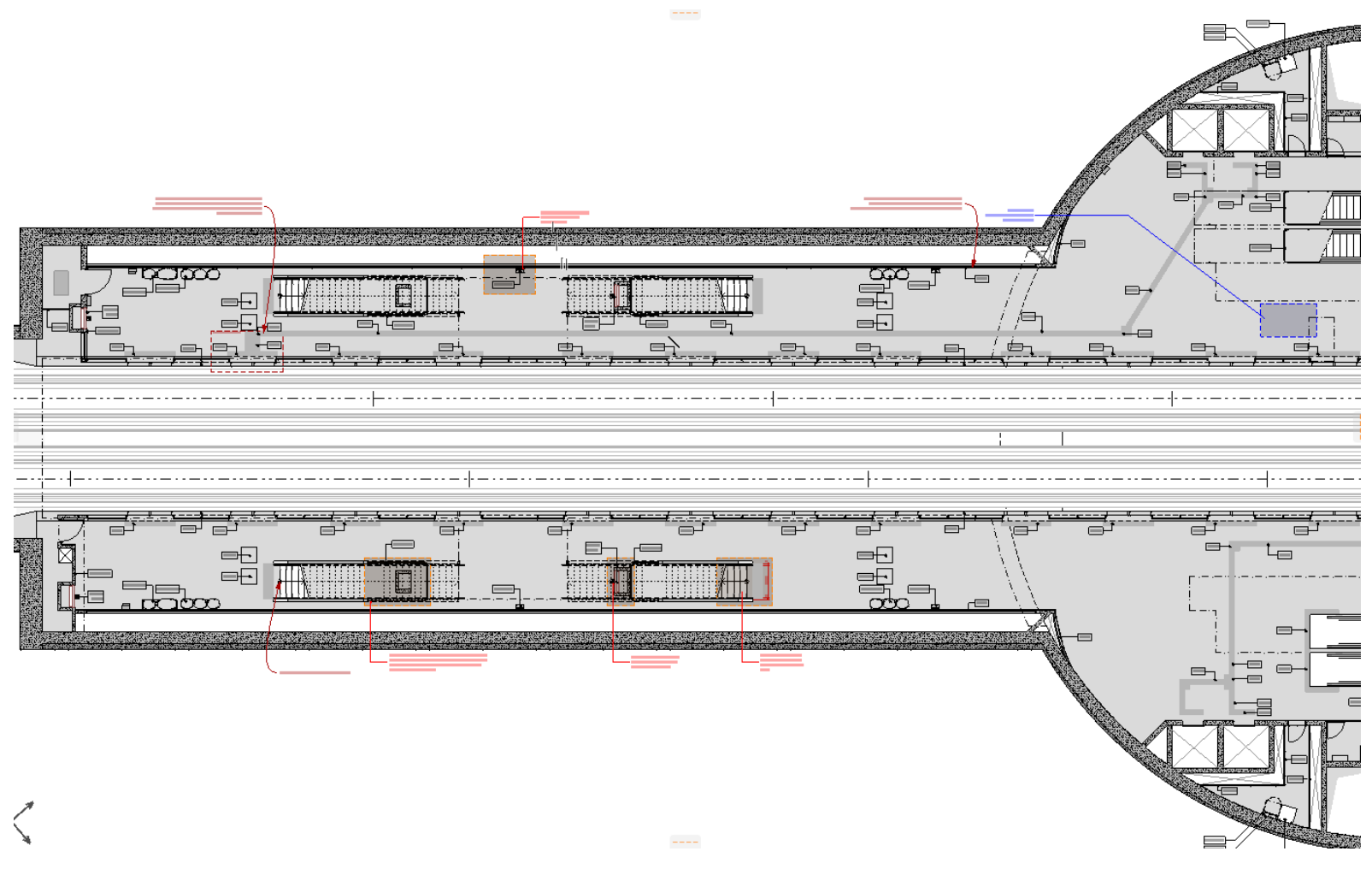

Fonte: Elaboração própria (2020).

\subsection{PARÂMETROS}

Este item da pesquisa irá compilar os parâmetros necessários para alteração automática do metacomponente em questão. É importante destacar que uma das grandes vantagens da biblioteca proposta está intrinsecamente ligada à parametrização. Embora os módulos possam ser utilizados sem ser paramétricos, alterando 'manualmente' os componentes para adaptação do modelo em diferentes projetos, seria um desperdício a não utilização da mesma, considerando a potencialidade e a essência paramétrica oferecida pelo BIM.

Conforme exposto nas referências bibliográficas, o AAD é outra tecnologia que pode ser utilizada para viabilização da biblioteca. No entanto, como esta é uma tarefa multidisciplinar, que envolve conhecimentos de linguagem de programação, além de cálculos específicos, que vão além do repertório da pesquisadora, a presente pesquisa irá se deter em descrever os algoritmos ou parâmetros para 0 
desenvolvimento dessa ferramenta, assim como a indicar as relações entre os parâmetros propostos.

De forma geral, a alteração do metacomponente está relacionada a três dimensões principais:

a) Diâmetro do poço: a dimensão está fortemente relacionada à demanda da estação, com interferência em diversos outros parâmetros internos, como os equipamentos de circulação (escadas fixas, rolantes e elevadores) e os dutos de ventilação vertical.

b) Altura do poço: relacionada principalmente a cota da via permanente e do saguão de entrada, ela define a quantidade e a altura de piso a piso dos mezaninos intermediários.

c) Seção do NATM: as dimensões do túnel que abriga as plataformas têm dois fatores principais, a demanda da estação e as condições do solo.

As dimensões citadas acima têm como premissas a cota da via permanente (topo do boleto) x cota do saguão de entrada (topografia do terreno), a estimativa de demanda da estação na hora pico e as condições do solo no local de implantação da edificação. A Figura 63 ilustra as principais dimensões do metacomponente desenvolvido.

O grande desafio da parametrização do metacomponente é permitir que as dimensões principais possam ser redefinidas, levando em consideração o redimensionamento dos espaços internos e equipamentos, como os dutos de ventilação, salas de equipamentos, escadas rolantes e caixa da escada pressurizada. Isso quer dizer que um simples escalonamento do projeto em planta, não irá garantir as adequações necessárias. A Figura 64 mostra que com um escalonamento do poço central os objetos como as escadas e equipamentos não se ajustam corretamente, sendo necessário estabelecer diversas regras e diretrizes para que o ajuste automático seja eficiente. 
Figura 63 - Principais parâmetros do metacomponente

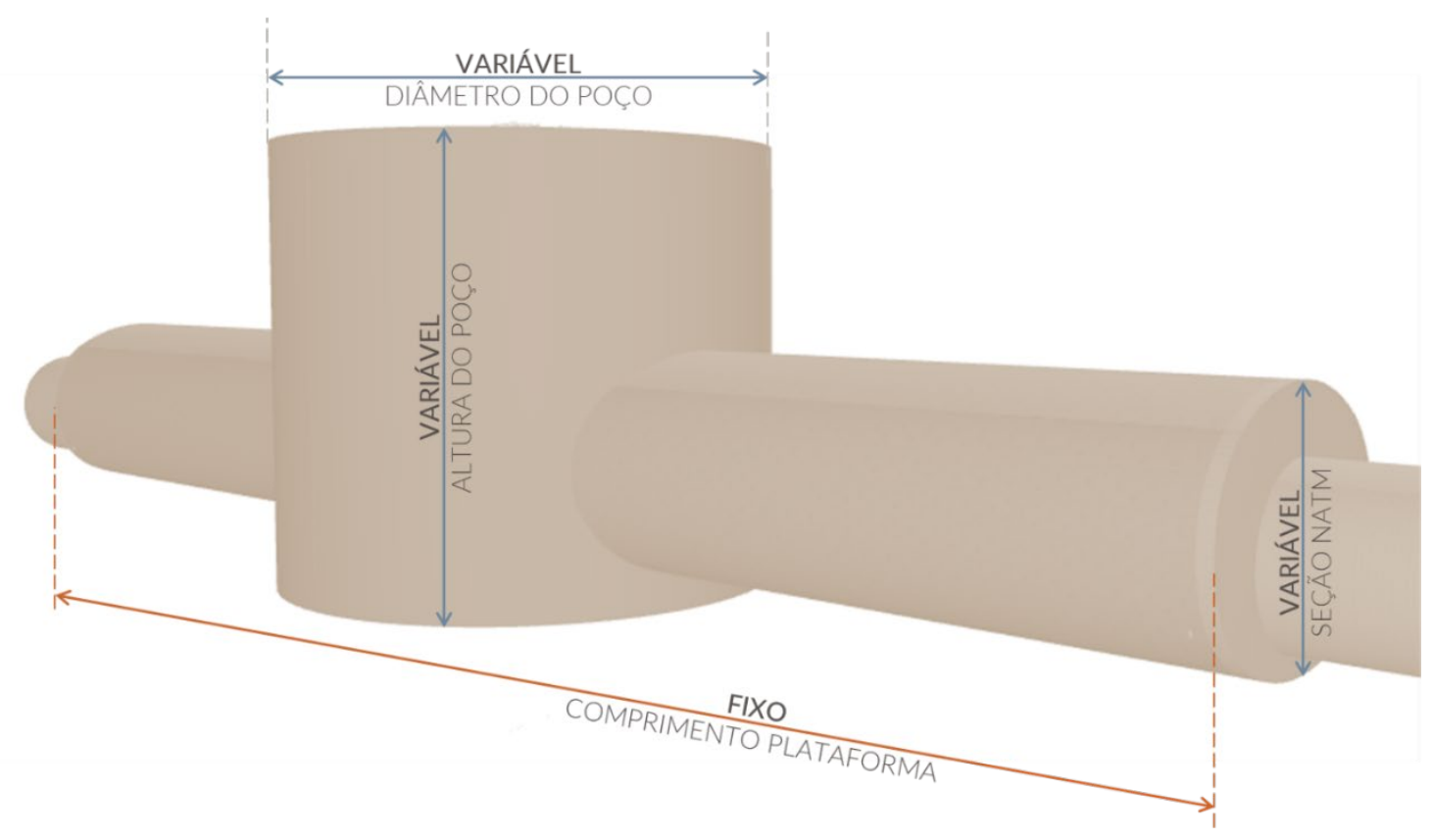

Fonte: Elaboração própria (2020).

Figura 64 - Escalonamento do projeto padrão

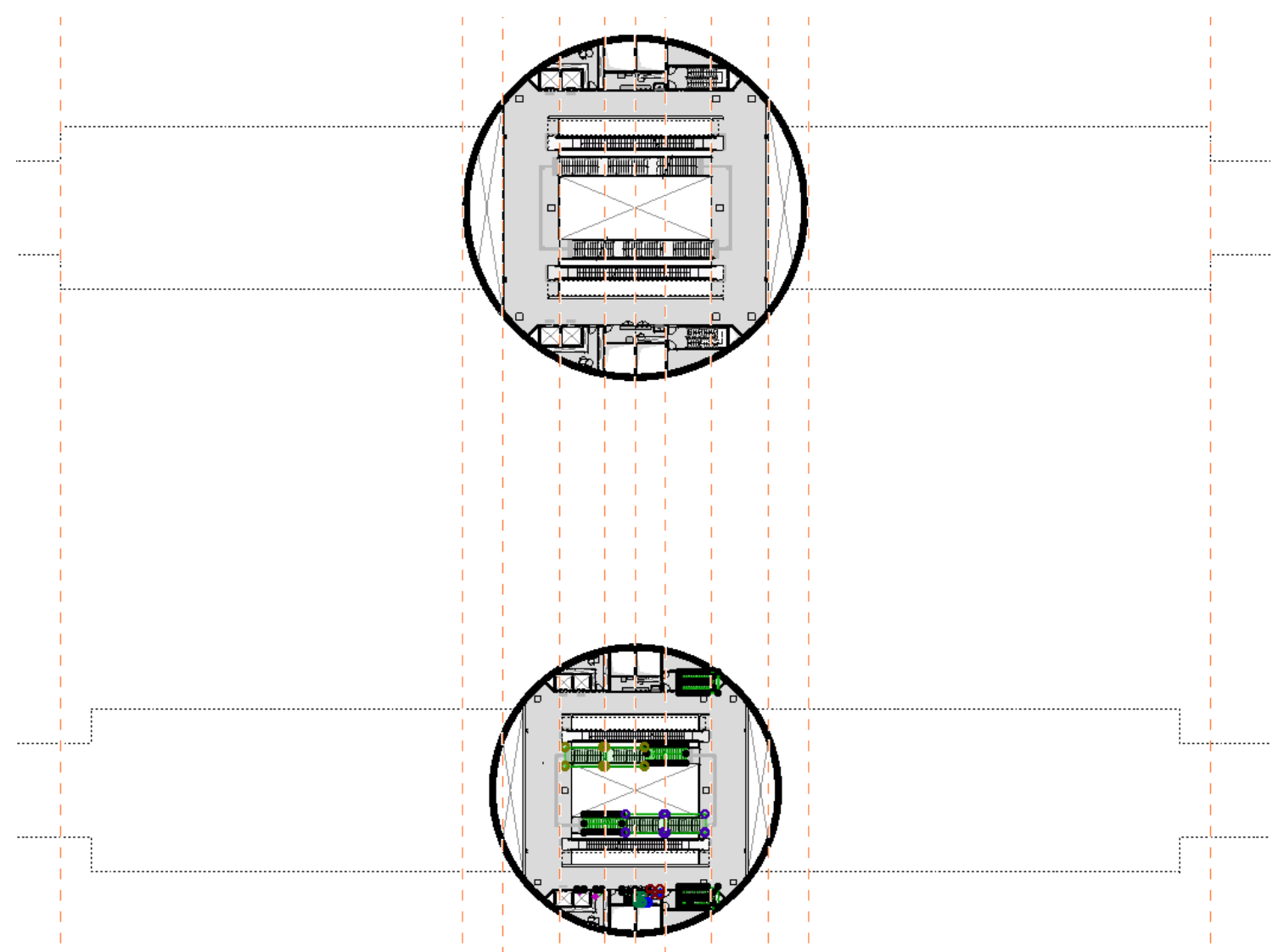

Fonte: Elaboração própria (2020). 
Um ajuste como este requer informar ao modelo uma série de dados para que os componentes se rearranjem no novo espaço, seguindo regras préestabelecidas. Por exemplo, no caso da diminuição do poço, uma nova altura de piso a piso tem que ser informada, para que as escadas fixas e rolantes adotem um novo número de degraus, que irá redimensionar o comprimento das mesmas na nova configuração do espaço. É preciso lembrar que toda a estrutura do mezanino deverá acompanhar o novo dimensionamento, sendo necessária uma revisão dessas medidas.

Os equipamentos e as prumadas de cabos possuem dimensões fixas e, portanto, as salas destinadas a eles devem manter seu tamanho original ou assumir uma dimensão mínima pré-estabelecida. Para viabilizar a redução é necessário também informar as novas medidas das seções dos dutos de ventilação e dos poços dos elevadores. O espaço de circulação pública deve ser reformulado de acordo com as regras mínimas de circulação, podendo também diminuir os vazios laterais do poço. Esse exemplo demonstra a complexidade da tarefa e expõe as inúmeras interrelações entre os componentes e espaços do modelo.

Com objetivo de percorrer todas as áreas do metacomponente, serão levantados abaixo os parâmetros por pavimento.

\subsubsection{Porão de cabos}

O porão de cabos é último pavimento habitado das estações. Sua função é estritamente técnica, direcionada a organização dos cabos que alimentam a via permanente e aos canais de ventilação. Neste piso também se encontram os acessos aos reservatórios de drenagem, que ficam abaixo deste nível.

Por ser um pavimento que possui acesso restrito ao público, o projeto padrão irá adotar as melhores características já experimentadas pelo Metrô/SP em relação aos acabamentos, manutenção e operação das áreas técnicas. O layout padrão deve ser respeitado em cada projeto novo, para garantir o uso do metacomponente. Esta característica também viabiliza a padronização dos projetos das demais disciplinas, como, por exemplo, sistemas, instalações e estrutura. Os 
projetos complementares devem ter variáveis relacionadas aos elementos arquitetônicos, para que os ajustes sejam feitos automaticamente no metacomponente.

As portas desse pavimento também foram padronizadas, portanto 0 metacomponente não oferece variações dos caixilhos neste nível. Essa situação é parecida com a dos revestimentos. A instrução complementar 9-00.00.00-3B3-00 estabelece uma lista dos materiais aplicados nas salas técnicas e operacionais, conforme mostra a Quadro 12.

Quadro 12 - Quadro geral de aplicação de materiais

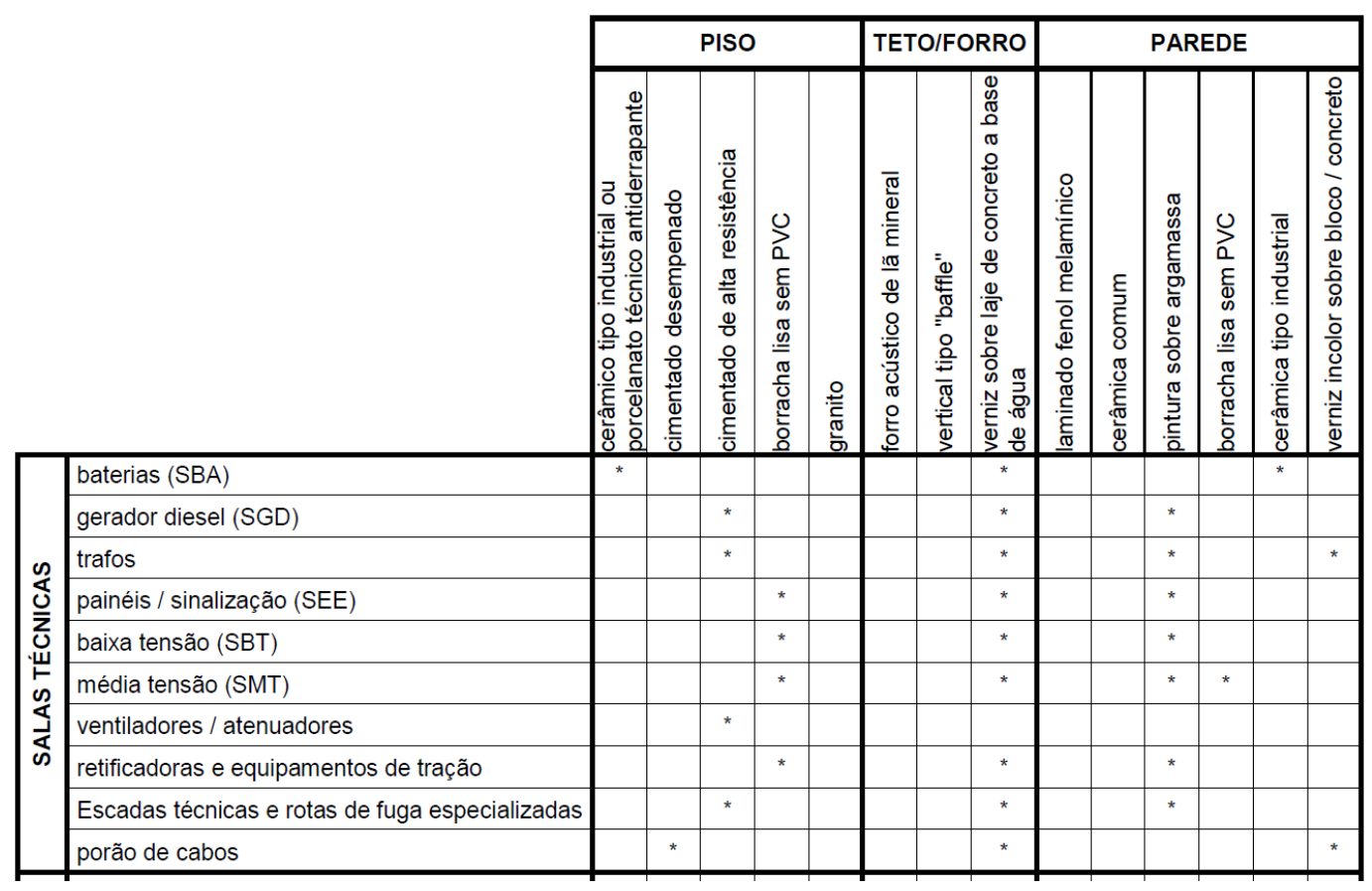

Fonte: CMSP (2013b).

Os acabamentos listados na tabela foram inseridos no metacomponente, e a cada revisão do mesmo, se forem constatadas novas tecnologias e materiais, estes podem ser alterados. Atualmente, os principais acabamentos do porão de cabos são o cimento desempenado (EC 08) para o piso, o verniz sobre laje de concreto a base de água (ED 21) para o teto e o verniz incolor sobre bloco / concreto (EB 15) para os acabamentos verticais. Os elementos foram modelados com os seus códigos dos acabamentos e dimensões padrão para serem quantificados e orçados. A Figura 65 apresenta o modelo do porão de cabos. 
Figura 65 - Porão de cabos modelado

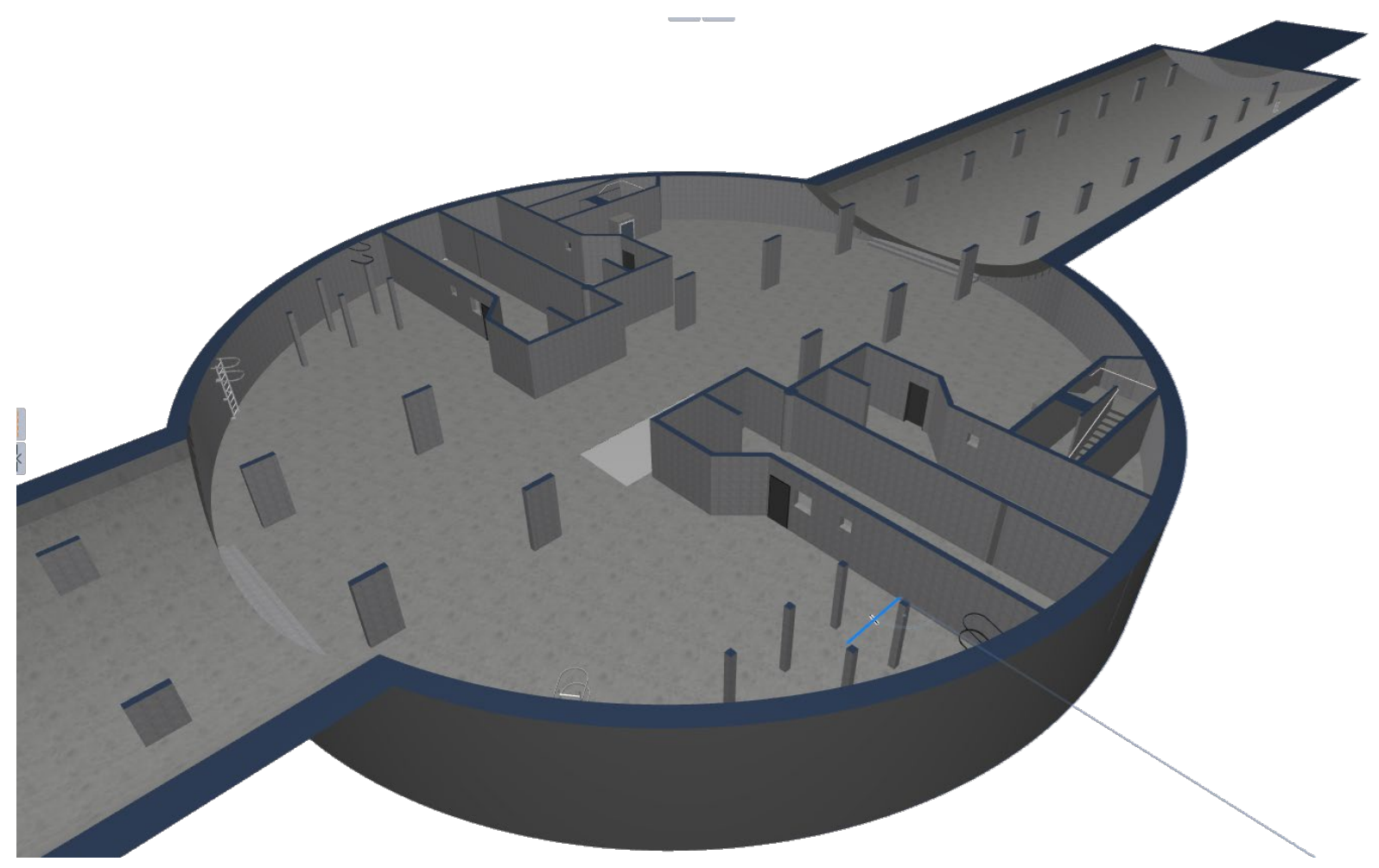

Fonte: Elaboração própria (2020).

Em termos de modelo, a laje de fundo da estação é uma composição entre o concreto estrutural e o cimento desempenado. Nesta composição já está indicada a espessura e o código do acabamento de piso. A laje superior e as paredes também são composições de concreto e verniz.

O Quadro 13 apresenta os itens do pavimento que não necessitam de alterações a cada novo projeto. Estes itens foram modelados e suas informações inseridas no metacomponente, conforme descrito no item 4.3 - Modelagem do metacomponente. 
Quadro 13 - Porão de cabos: itens fixos

\title{
Porão de cabos - Itens fixos
}

\section{Projeto Padrão \\ Justificativa}

Layout do pavimento
A disposição das paredes e equipamentos, como hidrantes, escadas marinheiro, prumadas de cabos, devem ser mantidas. Essa premissa viabiliza o metacomponente, inclusive com relação as demais disciplinas.

\section{Acabamentos \\ Como o porão de cabos é destinado apenas a áreas técnicas, os materiais de acabamentos são os mais utilizados pelo Metrô/SP. Estes materiais foram indicados e aplicados no metacomponente.}

Localização, tipo, dimensionamento e lado de abertura das portas
As portas devem seguir o padrão estabelecido, por se tratar de uma área técnica.

\section{Dimensão de hidrantes e ralos}

\begin{abstract}
A manutenção do layout e dimensões desses elementos viabiliza um projeto padrão de instalações. A localização dos hidrantes deve atender as regras dos decretos estatuais e instruções técnicas do corpo de bombeiros. Portanto, devem ser criadas regras de checagem para as distâncias entre os mesmos e as áreas da estação, principalmente no caso de alterações no diâmetro do poço.
\end{abstract}

\begin{abstract}
Esta dimensão é relacionada à largura da via permanente, que possui dimensão fixa.

Largura da escada entre o poço e o túnel.
\end{abstract}

A largura das prumadas tem dimensão mínima e fixa de $60 \mathrm{~cm}$,

Largura das prumadas de cabos do poço central podendo ter seu comprimento ser aumentado, dependendo das alterações do poço central.
Largura do corredor entre as prumadas de cabos
No metacomponente a dimensão mínima de 1,20 m da circulação será fixada.

\section{Dimensão e localização dos \\ itens de comunicação visual \\ (piso tátil, sinalizadores, \\ etc)}

Fonte: Elaboração própria (2020). 
Após descrever os itens fixos do Porão de cabos, serão analisados os espaços e componentes que necessitam de alterações a cada novo projeto. $\mathrm{O}$ parâmetro que possui maior impacto neste pavimento é o dimensionamento dos canais de ventilação. A seção necessária para a adequada insuflação e exaustão da estação é calculada de acordo com a profundidade e a estimativa de demanda. A largura da plataforma irá influenciar no comprimento do canal, e a altura do mesmo irá balizará o pé-direito do pavimento.

A largura do canal de ventilação, somada ao comprimento da escada de emergência, a largura dos elevadores, e a profundidade das prumadas de cabo com a sua circulação, resultará no diâmetro mínimo do poço central para o pavimento Porão de cabos. O Diagrama 1 apresenta de forma esquemática os dados de entrada, que são as informações iniciais que alimentarão os cálculos dos parâmetros; os componentes passíveis de alteração, que possuem os parâmetros do pavimento; e os dados de saída, que são dimensões resultantes dos cálculos. 


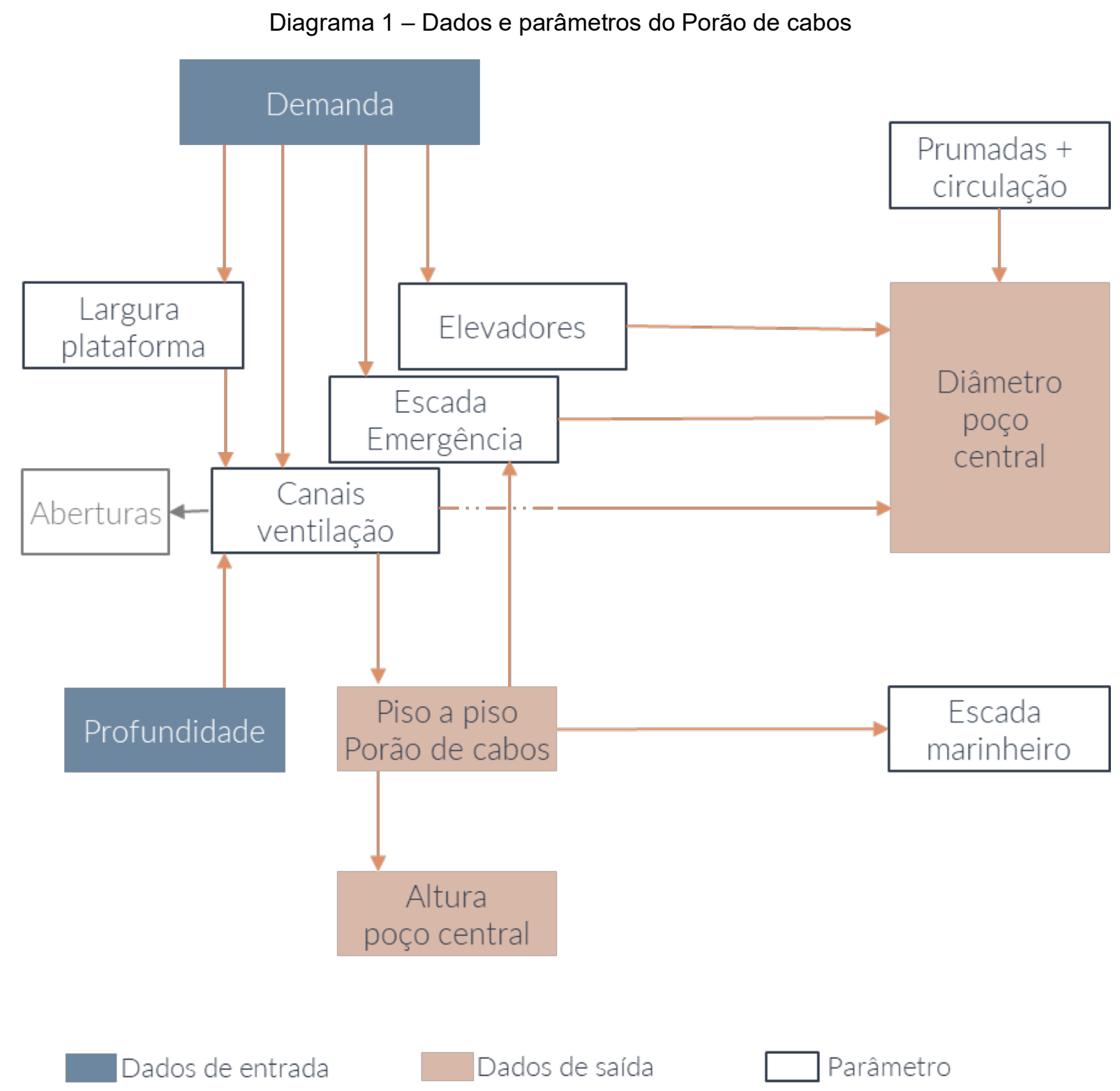

Fonte: Elaboração própria (2020).

Neste diagrama também é possível perceber as relações entre os parâmetros deste nível e a importância dos dados de estimativa de demanda e da cota do topo de boleto (profundidade da estação). Algumas variáveis deste pavimento estão relacionadas a outros pisos como, por exemplo, a dimensão dos elevadores e da escada de emergência. A Figura 66 ilustra os espaços e componentes passíveis de alteração no Porão de Cabos. 
Figura 66 - Parâmetros do Porão de Cabos

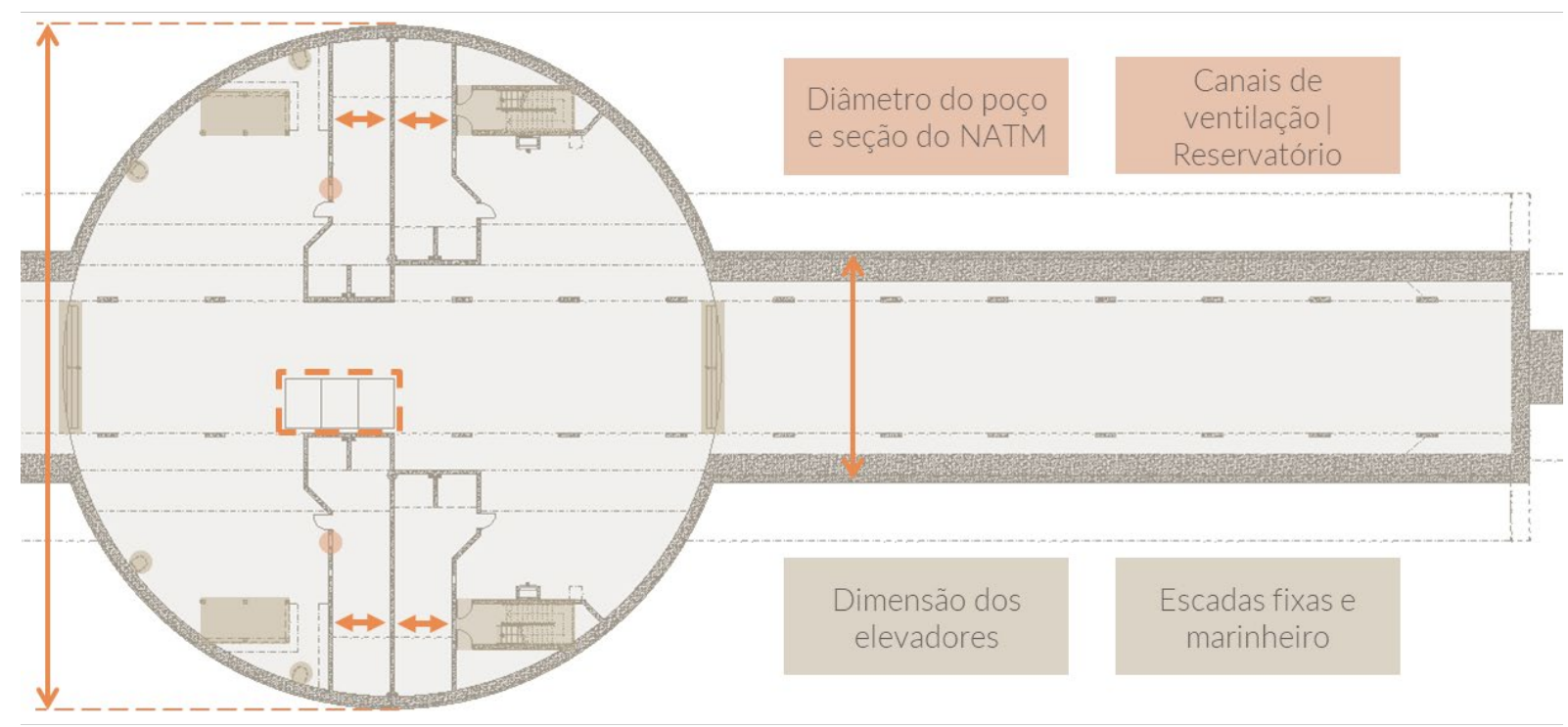

Fonte: Elaboração própria (2020).

A seção do túnel NATM sofrerá alteração de acordo com as características geológicas do local de implantação da estação e da estimativa de demanda da mesma. O dimensionamento do túnel e sua posição irão influenciar o número de degraus da escada que faz a junção entre o poço central e o túnel. $A$ largura desta escada é fixa, dimensionada de acordo com a via permanente, que é estabelecida pela dimensão dos carros que circularão na linha.

As aberturas dos canais de ventilação devem ser variáveis, e estabelecidas de acordo com cálculos específicos do projeto de sistemas, tanto em sua dimensão como nas características.

As escadas de emergência sofrerão alterações no seu comprimento dependendo do pé-direito do pavimento, que é estabelecido pelos cálculos da seção do canal de ventilação. As escadas marinheiro também dependem do pé-direito para sua configuração final.

Os elevadores e a largura da escada de emergência estão relacionados à estimativa de demanda da estação. Portanto, para o seu dimensionamento a ferramenta deve saber as regras, os cálculos específicos e o número da demanda. $O$ Quadro 14 lista os itens e as dimensões variáveis do pavimento, informando as regras que devem balizar as alterações e as relações entre os parâmetros. 
Quadro 14 - Porão de cabos: itens variáveis

\begin{tabular}{|c|c|c|c|}
\hline Item & Variável & Relação & Regras para alteração \\
\hline Canais de ventilação & $\begin{array}{l}\text { Largura, comprimento } \\
\text { e altura }\end{array}$ & $\begin{array}{l}\text { _Profundidade e } \\
\text { demanda da estação } \\
\text { _Diâmetro do poço } \\
\text { central } \\
\text { _ Altura do piso a piso } \\
\text { _Largura da } \\
\text { plataforma }\end{array}$ & $\begin{array}{l}\text { Cálculos específicos de } \\
\text { sistemas (área) }\end{array}$ \\
\hline $\begin{array}{l}\text { Reservatório de } \\
\text { drenagem }\end{array}$ & $\begin{array}{l}\text { Largura, comprimento } \\
\text { e altura }\end{array}$ & & $\begin{array}{l}\text { Cálculo específico de } \\
\text { hidráulica. }\end{array}$ \\
\hline Poço dos elevadores & $\begin{array}{l}\text { Largura e } \\
\text { comprimento }\end{array}$ & $\begin{array}{l}\text { _Diâmetro do poço } \\
\text { central } \\
\text { _Estimativa de } \\
\text { demanda }\end{array}$ & $\begin{array}{l}\text { _Dimensão mínima } \\
\text { _Cálculo de tráfego }\end{array}$ \\
\hline $\begin{array}{l}\text { Escada de } \\
\text { emergência (degraus } \\
\text { e corrimão) }\end{array}$ & $\begin{array}{l}\text { _Duto de } \\
\text { pressurização (área) } \\
\text { _Largura } \\
\mathrm{N}^{\circ} \text { de degraus: altura } \\
\text { e comprimento da } \\
\text { escada }\end{array}$ & $\begin{array}{l}\text { Profundidade e } \\
\text { demanda da estação }\end{array}$ & $\begin{array}{l}\text { _Cálculo: 1.300phd } \mathrm{x} \\
\text { can }^{21} \\
\text { _Altura degrau }=0,16 \mathrm{~m} \\
\text { _Largura degrau }= \\
0,31 \mathrm{~m} \\
\text { _Largura mínima }= \\
1,20 \mathrm{~m}\end{array}$ \\
\hline Estrutura & $\begin{array}{l}\text { _Posição e dimensão } \\
\text { dos pilares e vigas } \\
\text { _Laje de fundo }\end{array}$ & $\begin{array}{l}\text { _Diâmetro do poço } \\
\text { _Piso a piso do } \\
\text { pavimento } \\
\text { _Poço de elevadores }\end{array}$ & _Cálculo estrutural \\
\hline $\begin{array}{l}\text { Largura e número de } \\
\text { degraus da escada } \\
\text { de ajuste entre o } \\
\text { poço e o túnel }\end{array}$ & $\begin{array}{l}\text { Dimensões e posição } \\
\text { do poço e túnel > } \\
\text { características } \\
\text { geológicas + demanda }\end{array}$ & $\begin{array}{l}\text { Diâmetro do poço } \\
\text { central e seção do } \\
\text { NATM }\end{array}$ & \\
\hline $\begin{array}{l}\text { Pé-direito do } \\
\text { pavimento }\end{array}$ & $\begin{array}{l}\text { Cálculos específicos } \\
\text { de sistemas (área dos } \\
\text { canais de ventilação) }\end{array}$ & $\begin{array}{l}\text { Altura dos canais de } \\
\text { ventilação }\end{array}$ & $\begin{array}{l}\text { Altura dos degraus } \\
\text { (múltiplo de } 0,16 \mathrm{~m} \text { ) }\end{array}$ \\
\hline
\end{tabular}

Fonte: Elaboração própria (2020).

20 Segundo critérios da NBR 5665/83, um elevador deve ser capaz de transportar de 6 a $15 \%$ da população total de um edifício em 5 minutos, portanto, o que determina o tamanho e a velocidade dele é o cálculo de tráfego.

${ }^{21}$ A capacidade das escadas fixas deverá ser calculada em pessoas por hora pico (php) por canal de circulação em $0,60 \mathrm{~m}$ de largura (can). 


\subsubsection{Canal de ventilação inferior}

O pavimento acima do porão de cabos e abaixo das plataformas abriga os canais de ventilação e a via permanente. Os canais de ventilação inferior são responsáveis pela distribuição e renovação do ar nos níveis mais profundos das estações subterrâneas. Este nível tem inúmeras semelhanças com o porão de cabos, configurando também uma área técnica da estação, com acesso exclusivo aos funcionários habilitados.

Com o objetivo de viabilizar um ajuste automático do metacomponente, o layout padrão deste nível não poderá ser alterado, mantendo as conexões já estabelecidas entre os principais componentes. Os materiais de acabamento e as portas do pavimento também são padronizados, de acordo com a experiência do Metrô/SP. O Quadro 15 descreve os itens fixos do Canal de Ventilação Inferior.

\section{Quadro 15 - Canal de ventilação inferior: itens fixos}

\begin{tabular}{|c|c|}
\hline & Canal de ventilação inferior \\
\hline Projeto Padrão (sem variável) & Justificativa \\
\hline Layout do pavimento & $\begin{array}{l}\text { A disposição dos espaços e equipamentos deve ser mantida para } \\
\text { viabilizar metacomponente, inclusive com relação aos elementos } \\
\text { das disciplinas de sistemas, instalações e estrutura. }\end{array}$ \\
\hline Acabamentos & $\begin{array}{l}\text { Como o porão de cabos é uma área técnica, os materiais de } \\
\text { acabamentos aplicados no modelo são os padrões, mais } \\
\text { utilizados pelo Metrô/SP. }\end{array}$ \\
\hline $\begin{array}{l}\text { Localização, tipo, } \\
\text { dimensionamento e lado de } \\
\text { abertura das portas }\end{array}$ & $\begin{array}{l}\text { As portas são padronizadas por se estarem em uma área } \\
\text { técnica. }\end{array}$ \\
\hline $\begin{array}{l}\text { Largura das prumadas de } \\
\text { cabos do poço central }\end{array}$ & $\begin{array}{l}\text { A largura das prumadas tem dimensão mínima e fixa de } 60 \mathrm{~cm} \text {, } \\
\text { podendo ter seu comprimento ser aumentado, dependendo das } \\
\text { alterações do poço central. }\end{array}$ \\
\hline $\begin{array}{l}\text { Largura do corredor entre as } \\
\text { prumadas de cabos }\end{array}$ & $\begin{array}{l}\text { No metacomponente a dimensão mínima de 1,20m da circulação } \\
\text { será fixada. }\end{array}$ \\
\hline
\end{tabular}




\section{Canal de ventilação inferior}

\section{Projeto Padrão (sem variável) Justificativa}

\section{Dimensão e localização dos}

itens de comunicação visual

(piso tátil, sinalizadores, etc)

Fonte: Elaboração própria (2020).

As variáveis deste nível são compostas principalmente por alterações nos dutos e canais de ventilação. A largura dos canais de ventilação está diretamente relacionada à dimensão da plataforma, portanto pequenos ajustes na altura dos canais possibilitará alterações na seção dos mesmos.

Conforme estabelecido pelo Metrô/SP o piso a piso dos pavimentos deve ser múltiplo de 0,16. As escadas fixas e marinheiro serão variáveis para absorverem essas alterações na altura dos canais. Modificações na largura da plataforma e, consequentemente, nos canais de ventilação influenciam a seção do túnel NATM. A Figura 67 apresenta um corte no túnel NATM e, a partir dele, é possível entender as relações entre as dimensões da plataforma e a seção dos canais.

As aberturas no canal de exaustão ao longo das plataformas têm como função recolher o ar dos níveis mais profundos da estação, principalmente das plataformas onde pode haver maior quantidade de pessoas e um tempo de permanência maior. $\mathrm{O}$ ar renovado é insuflado na plataforma através do canal de insuflação. A Figura 68 ilustra o caminho do ar que será insuflado na plataforma (cor azul) e o que será retirado (cor vermelha) da estação. 
Figura 67 - Corte túnel NATM

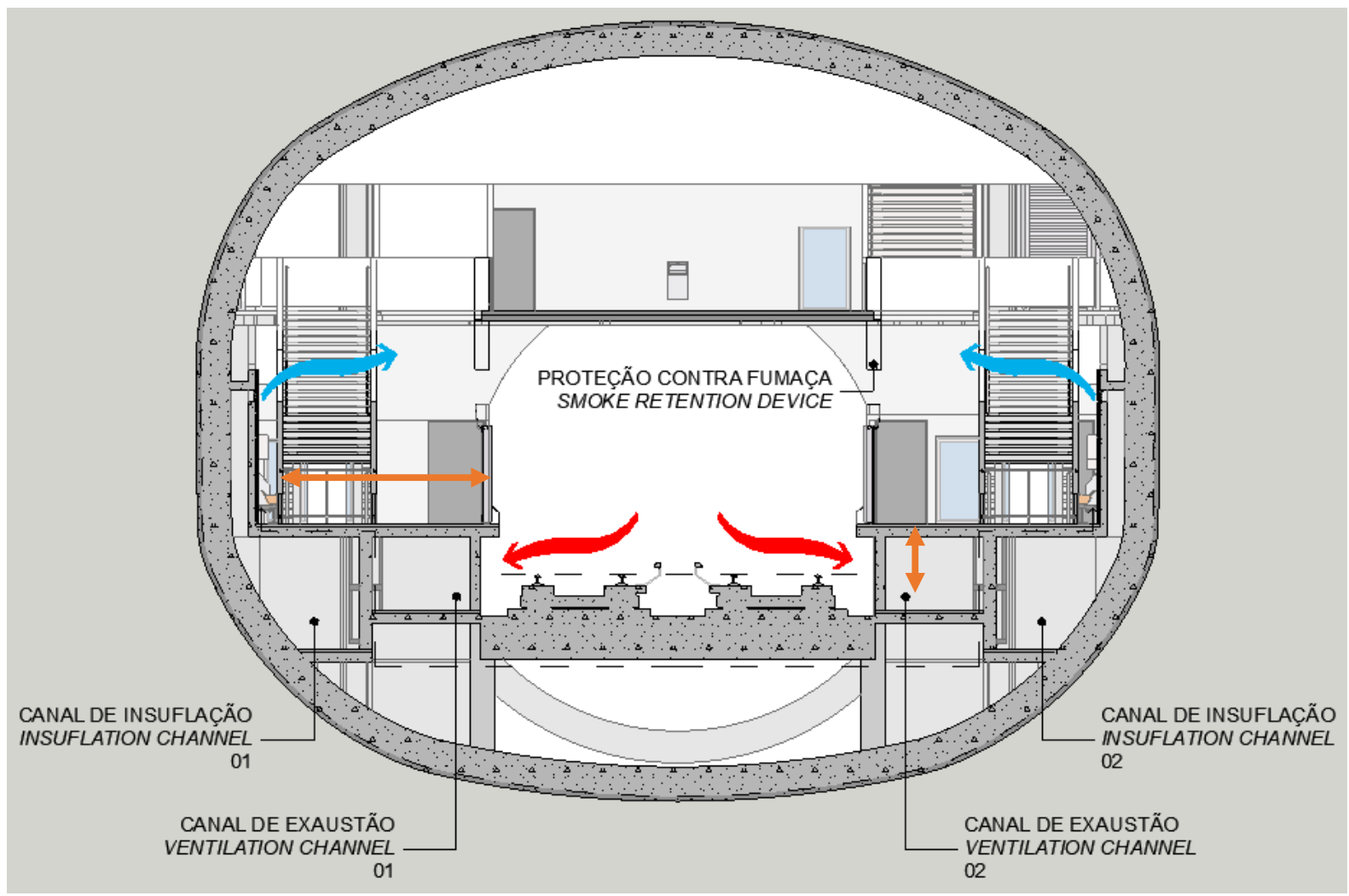

Fonte: Elaboração própria (2020).

Figura 68 - Planta exaustão e insuflação da plataforma

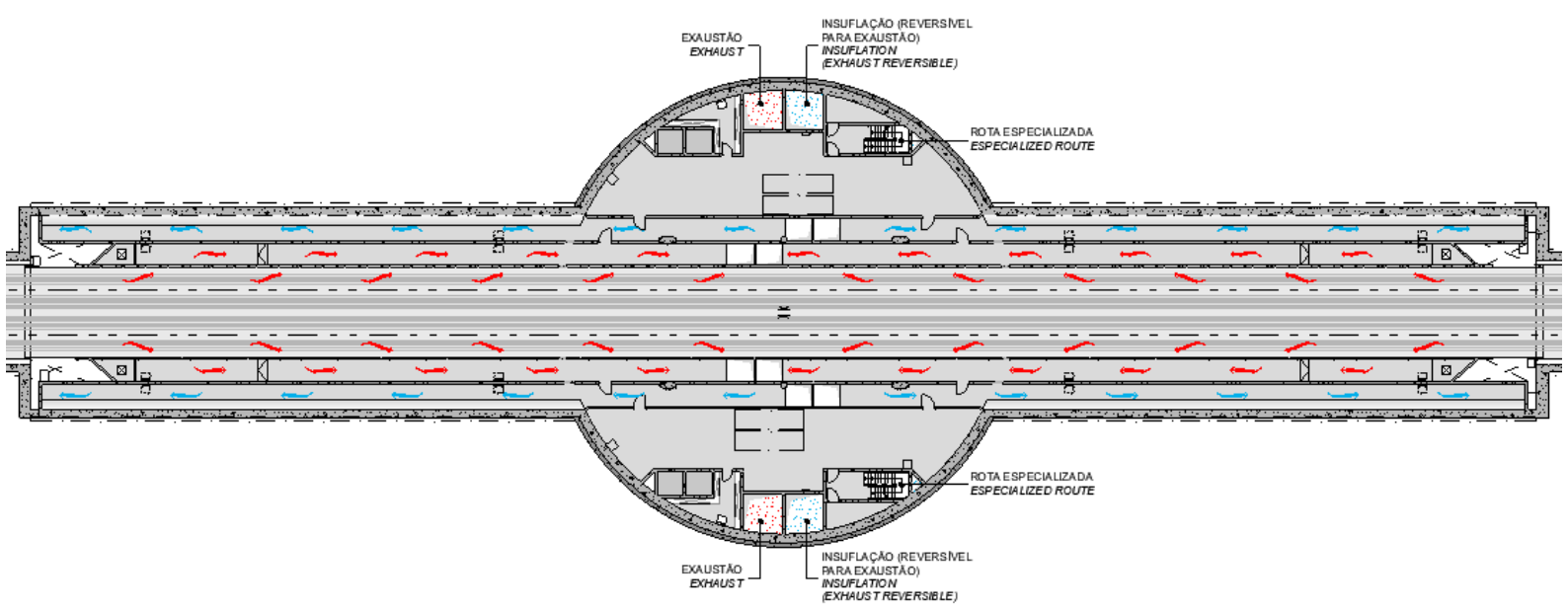

Fonte: Elaboração própria (2020). 
O dimensionamento desses canais e das suas aberturas é feito através de cálculos específicos da disciplina de sistemas. Portanto, neste nível, todas as aberturas dos canais deverão ser variáveis, e estão condicionadas a esses cálculos. A Figura 69 ilustra, através do modelo do metacomponente, um canal de exaustão, com as aberturas de dimensões variáveis.

Figura 69 - Canal de ventilação

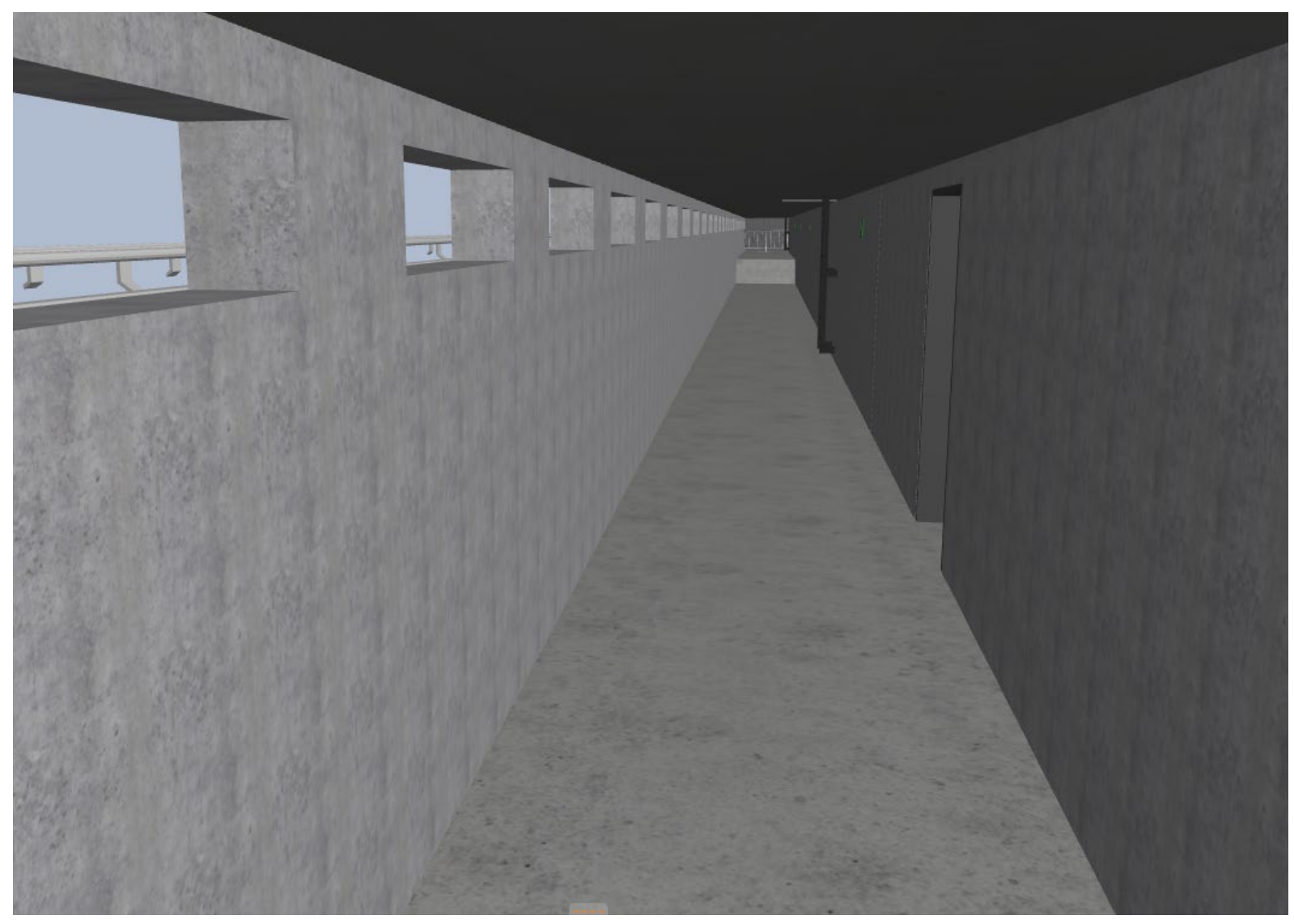

Fonte: Elaboração própria (2020).

A estimativa de demanda é um item importante também para este pavimento, influenciando no dimensionamento da plataforma, elevadores, escada de emergência, dutos e canais de ventilação. O Diagrama 2 apresenta os principais parâmetros do pavimento Canal de ventilação inferior, e suas relações. 
Diagrama 2 - Dados e parâmetros do Canal de Ventilação Inferior

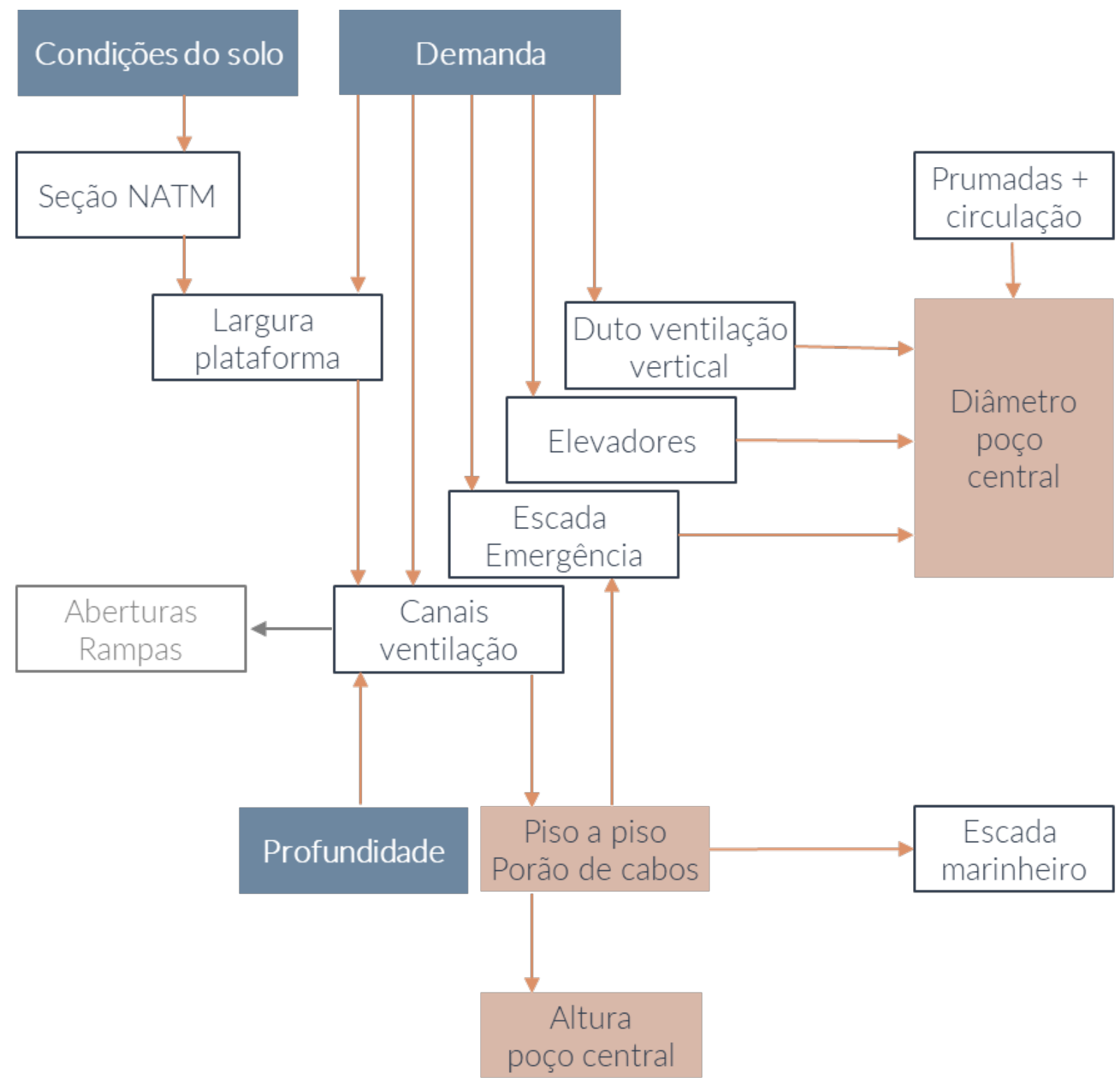

Dados de entrada

Fonte: Elaboração própria (2020).

O diâmetro do poço central se dará a partir da configuração dos itens: duto de ventilação vertical, elevadores, comprimento da escada de emergência e da sala de cabos. A Figura 70 representa os principais parâmetros do pavimento destacando os itens em planta. 
Figura 70 - Parâmetros do Canal de ventilação Inferior

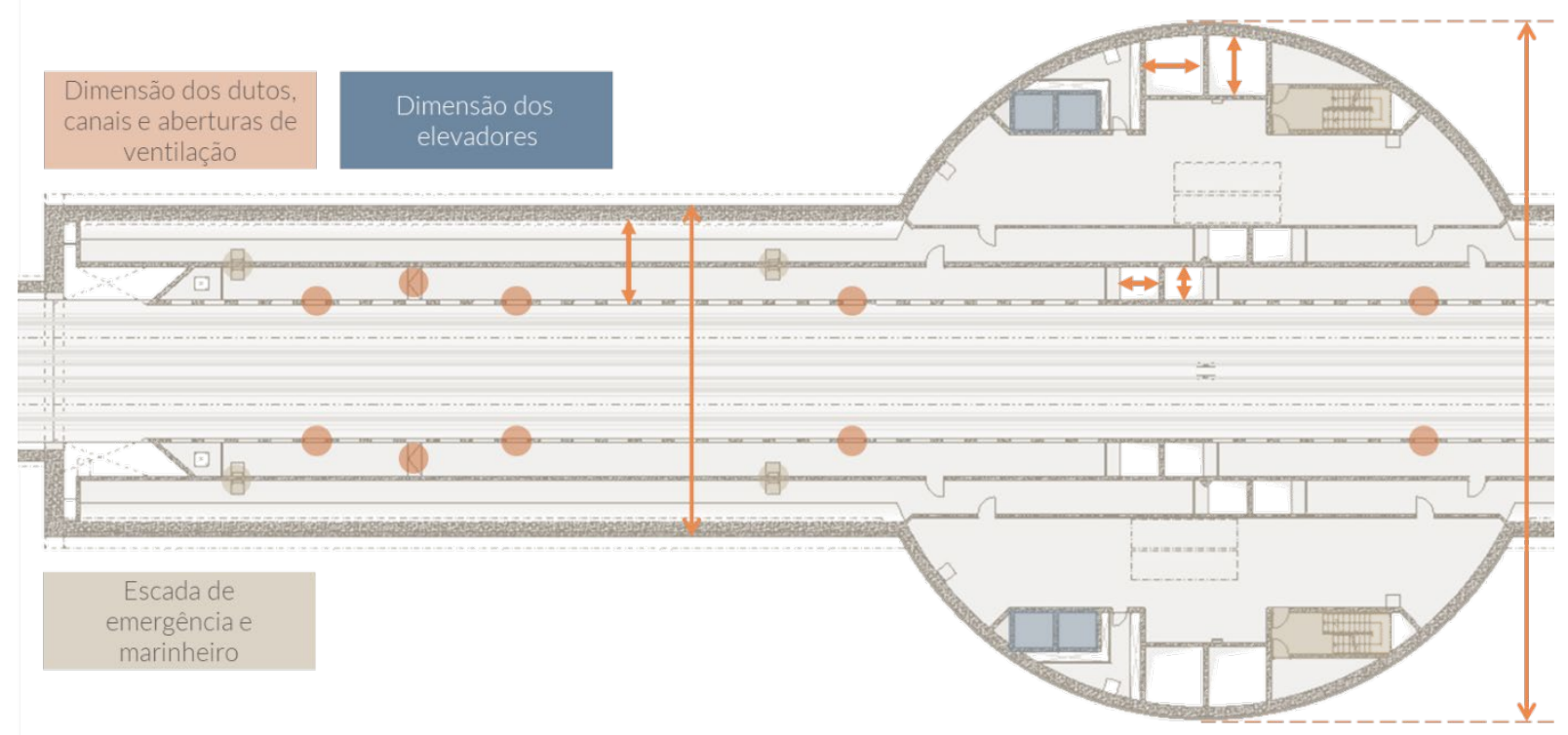

Fonte: Elaboração própria (2020).

O Quadro 16 descreve os itens apresentados na figura acima, apontando suas relações e as regras envolvidas nas alterações.

Quadro 16 - Canal de ventilação inferior: itens variáveis

\begin{tabular}{|c|c|c|c|}
\hline Item & Variável & Relação & $\begin{array}{l}\text { Regras para } \\
\text { alteração }\end{array}$ \\
\hline \multirow[t]{2}{*}{ Canais de ventilação } & Largura e altura & $\begin{array}{l}\text { _Profundidade e } \\
\text { demanda da estação }\end{array}$ & $\begin{array}{l}\text { Cálculos específicos } \\
\text { de sistemas (área) }\end{array}$ \\
\hline & & $\begin{array}{l}\text { _Diâmetro do poço } \\
\text { central }\end{array}$ & \\
\hline \multirow[t]{2}{*}{ Poço dos elevadores } & Largura e comprimento & $\begin{array}{l}\text { _Diâmetro do poço } \\
\text { central }\end{array}$ & $\begin{array}{l}\text { _Dimensão mínima } \\
\text { Cálculo de tráfego }\end{array}$ \\
\hline & & $\begin{array}{l}\text { Estimativa de } \\
\text { demanda }\end{array}$ & \\
\hline
\end{tabular}

22 Segundo critérios da NBR 5665/83, um elevador deve ser capaz de transportar de 6 a $15 \%$ da população total de um edifício em 5 minutos, portanto, o que determina o tamanho e a velocidade dele é o cálculo de tráfego. 


\begin{tabular}{|c|c|c|c|}
\hline Item & Variável & Relação & $\begin{array}{l}\text { Regras para } \\
\text { alteração }\end{array}$ \\
\hline $\begin{array}{l}\text { Escada de } \\
\text { emergência (degraus } \\
\text { e corrimão) }\end{array}$ & $\begin{array}{l}\text { _Duto de } \\
\text { pressurização (área) } \\
\text { _Largura } \\
{ }^{\mathrm{N}}{ }^{\circ} \text { de degraus: altura } \\
\text { e comprimento da } \\
\text { escada }\end{array}$ & $\begin{array}{l}\text { _Demanda da estação } \\
\text { _Piso a piso do } \\
\text { pavimento }\end{array}$ & $\begin{array}{l}\text { _Cálculo: 1.300phd } x \\
\text { can }^{23} \\
\text { _Altura degrau }= \\
0,16 \mathrm{~m} \\
\text { _Largura degrau }= \\
0,31 \mathrm{~m} \\
\text { _Largura mínima }= \\
1,20 \mathrm{~m}\end{array}$ \\
\hline Estrutura & $\begin{array}{l}\text { espessura das } \\
\text { paredes e vigas }\end{array}$ & $\begin{array}{l}\text { DDiâmetro do poço } \\
\text { _Piso a piso do } \\
\text { pavimento }\end{array}$ & _Cálculo estrutural \\
\hline $\begin{array}{l}\text { Pé-direito do } \\
\text { pavimento }\end{array}$ & $\begin{array}{l}\text { Cálculos específicos } \\
\text { de sistemas (área dos } \\
\text { canais de ventilação) }\end{array}$ & $\begin{array}{l}\text { Altura dos dutos de } \\
\text { ventilação }\end{array}$ & $\begin{array}{l}\text { Altura dos degraus } \\
\text { (múltiplo de } 0,16 \mathrm{~m} \text { ) }\end{array}$ \\
\hline $\begin{array}{l}\text { Dimensão das } \\
\text { aberturas dos canais } \\
\text { de ventilação }\end{array}$ & $\begin{array}{l}\text { Cálculos específicos } \\
\text { de sistemas }\end{array}$ & $\begin{array}{l}\text { Parede de divisão do } \\
\text { duto com a via } \\
\text { permanente }\end{array}$ & \\
\hline
\end{tabular}

Fonte: Elaboração própria (2020).

\subsubsection{Plataforma}

O nível da plataforma é onde o embarque e o desembarque dos passageiros é realizado. Os ambientes públicos das estações como, a plataforma, por exemplo, necessitam estabelecer uma identidade visual com a linha em que a estação está inserida, além de transmitirem conforto ao usuário. Portanto, nestes ambientes o metacomponente deverá possibilitar maiores alterações em termos de acabamentos e da comunicação visual.

Diferente dos pavimentos estudados anteriormente, a plataforma não tem variáveis que influenciam diretamente no piso a piso do pavimento. Portanto a altura das escadas pode ser fixa neste nível. A altura do topo do boleto (via permanente) para o piso acabado da plataforma também é fixa, e se constitui em uma regra para

\footnotetext{
${ }^{23}$ A capacidade das escadas fixas deverá ser calculada em pessoas por hora pico (php) por canal de circulação em $0,60 \mathrm{~m}$ de largura (can).
} 
o ajuste da posição real do metacomponente em relação ao terreno da estação projetada. A Figura 71 ilustra através de um corte a regra de altura entre o topo do boleto e a plataforma, que deve ser mantida em todos os projetos.

Figura 71 - Regra: diferença de altura entre o T.B. e a plataforma

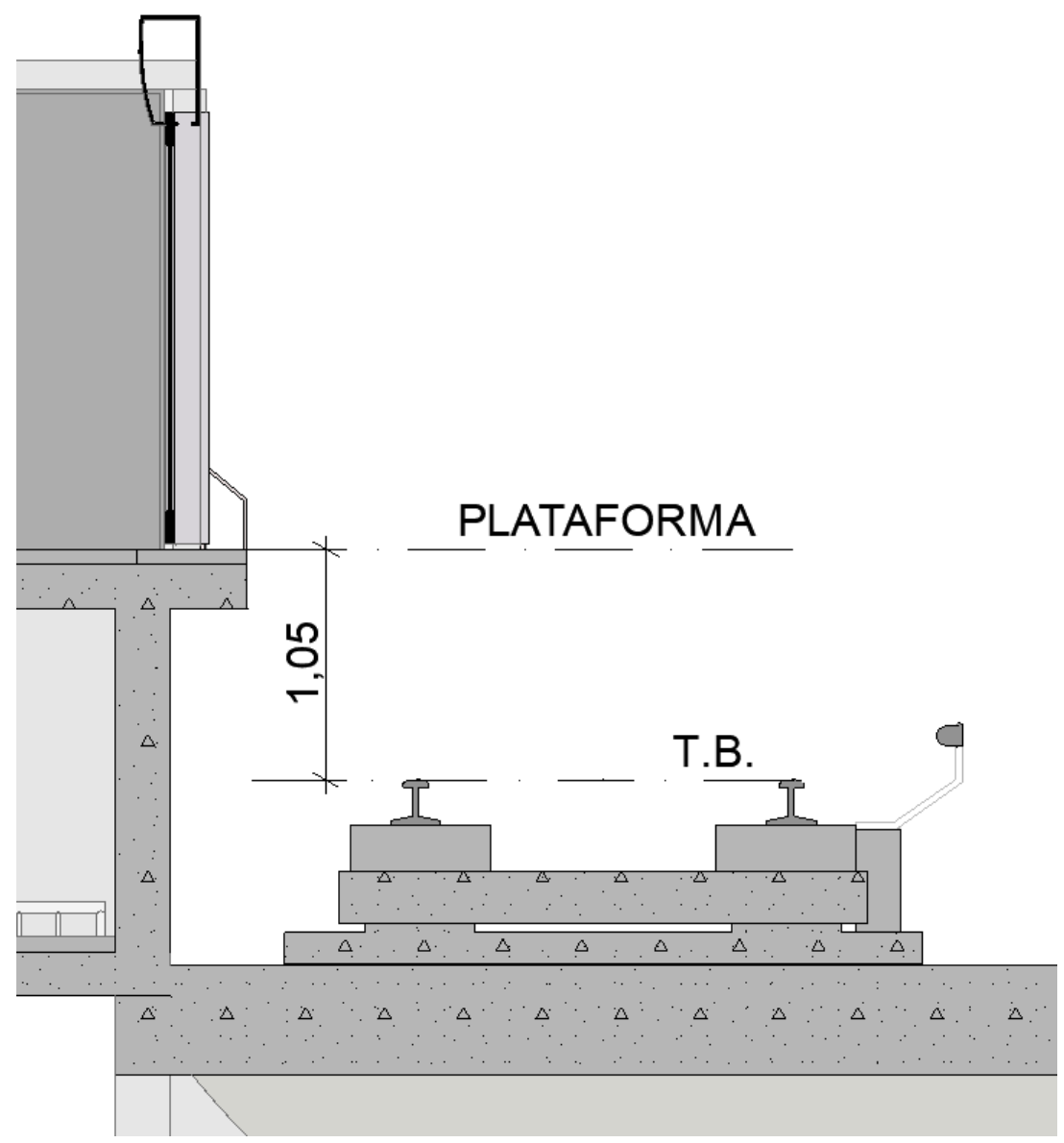

Fonte: Elaboração própria (2020).

As elevações reais do projeto devem acompanhar a cota do topo do boleto que será apontada na definição do traçado da via permanente. Esta deve ser atribuída em um campo específico que irá definir as cotas de elevação dos demais pavimentos. A regra deve estabelecer que o nível da plataforma se encontra a 1,05 $\mathrm{m}$ da altura dada do topo do boleto (TB). Ajustando desta forma o metacomponente à elevação real do projeto.

O Quadro 17 descreve os itens que não possuem variáveis nas plataformas. 
Quadro 17 - Plataforma: itens fixos

\section{Plataforma}

\section{Projeto Padrão (sem Justificativa \\ variável)}

Layout do pavimento A disposição dos espaços e equipamentos deve ser mantida para viabilizar metacomponente, inclusive com relação aos elementos das disciplinas de sistemas, instalações e estrutura.
Comprimento das O comprimento das plataformas é fixado em $136 \mathrm{~m}$, em função do tamanho plataformas (túnel dos carros.

NATM)

Porta da plataforma Como a plataforma só sofre ajustes na sua largura, o componente 'porta de plataforma' pode ser fixo.

\begin{tabular}{|c|c|}
\hline Via permanente & $\begin{array}{l}\text { A largura e o eixo da via permanente são fixados nas definições } \\
\text { tecnológicas da linha, que deverá ser padronizada. }\end{array}$ \\
\hline Escadas Fixas & $\begin{array}{l}\text { As escadas fixas que levam ao mezanino inferior possuem altura e } \\
\text { comprimento fixos, uma vez que o piso a piso do nível é fixado em 4,32m. } \\
\text { É importante destacar que as escadas possuem uma área de } \\
\text { acomodação, que devem ser mantidas livres de qualquer mobiliário ou } \\
\text { equipamentos, sendo necessário manter o layout padrão. }\end{array}$ \\
\hline
\end{tabular}

Largura das prumadas A largura das prumadas tem dimensão mínima e fixa de $60 \mathrm{~cm}$, podendo ter de cabos do poço seu comprimento ser aumentado, dependendo das alterações do poço central central.
Largura do corredor No metacomponente a dimensão mínima de 1,20m da circulação será entre as prumadas de fixada.
cabos
Dimensão dos
Os componentes de mobiliário e equipamentos técnicos possuem equipamentos $\mathbf{e}$ dimensões padronizadas, e, portanto, fixas. Podendo sofrer ajustes em sua mobiliário posição.

Fonte: Elaboração própria (2020). 
De forma geral, o metacomponente deverá oferecer mais variáveis no nível das plataformas, assim como um número maior de relações entre eles. Como o pavimento apresenta mais componentes, cada alteração provoca uma mudança em cadeia. O Diagrama 3 ilustra as relações entre os parâmetros do nível.

Diagrama 3 - Dados e parâmetros da Plataforma

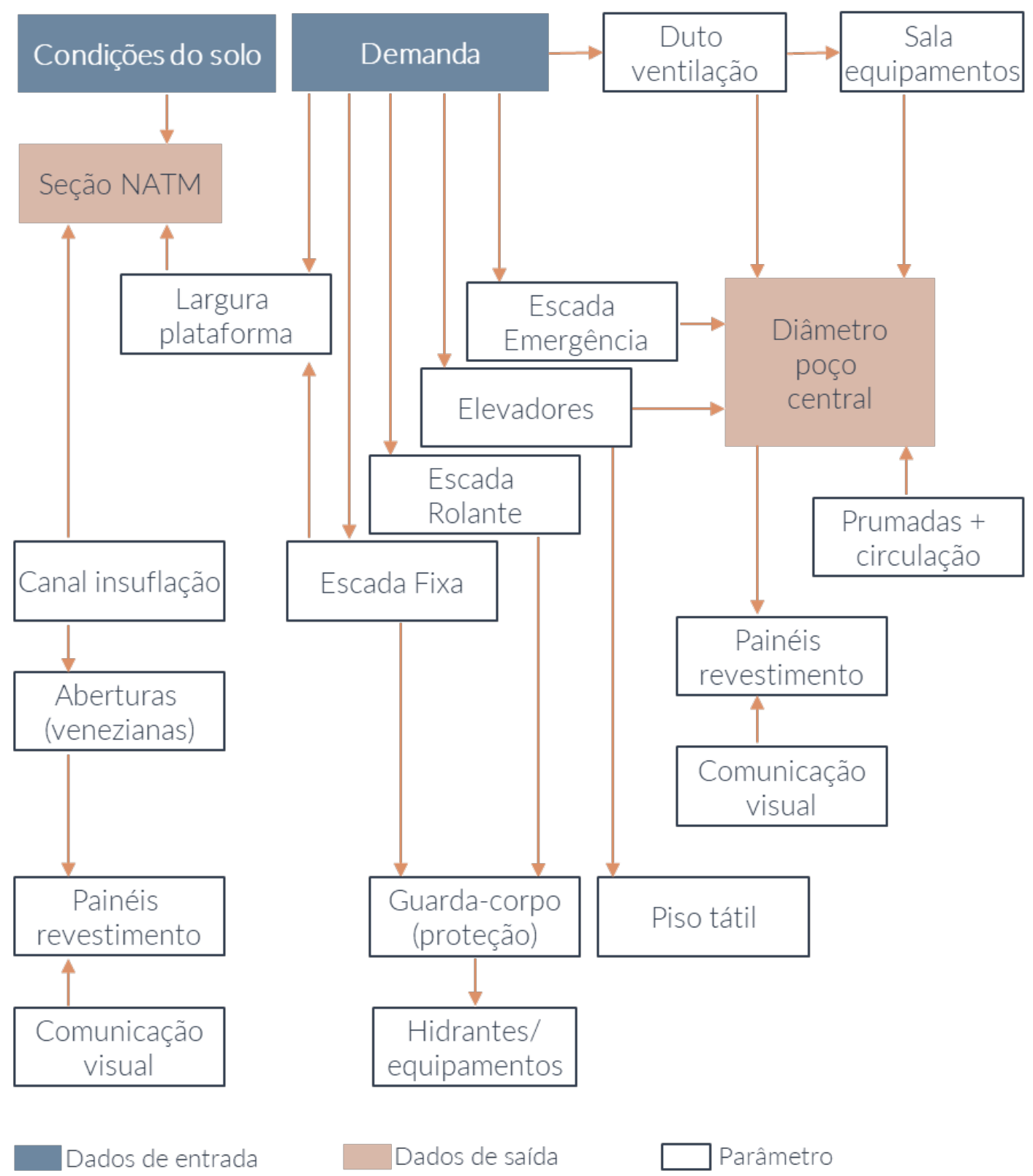

Fonte: Elaboração própria (2020).

A largura da plataforma e da escada fixa influencia diretamente na seção do túnel NATM. O desenho desta seção é definido também pelas condições do solo, portanto a alteração no túnel é feita por um desenho de seção variável. O canal de 
insuflação compõe a lateral do túnel, e a partir das venezianas instaladas nele insufla-se ar na plataforma. As dimensões dessas aberturas são calculadas pela disciplina de sistemas, e podem influenciar na modulação dos painéis de revestimento, que tem também relação com a comunicação visual da estação. A Figura 72 apresenta um corte do túnel NATM modelado, indicando as dimensões variáveis e fixas do metacomponente neste local, e os elementos que também podem sofrer alterações.

Figura 72 - Corte Túnel NATM: Dimensões variáveis e fixas

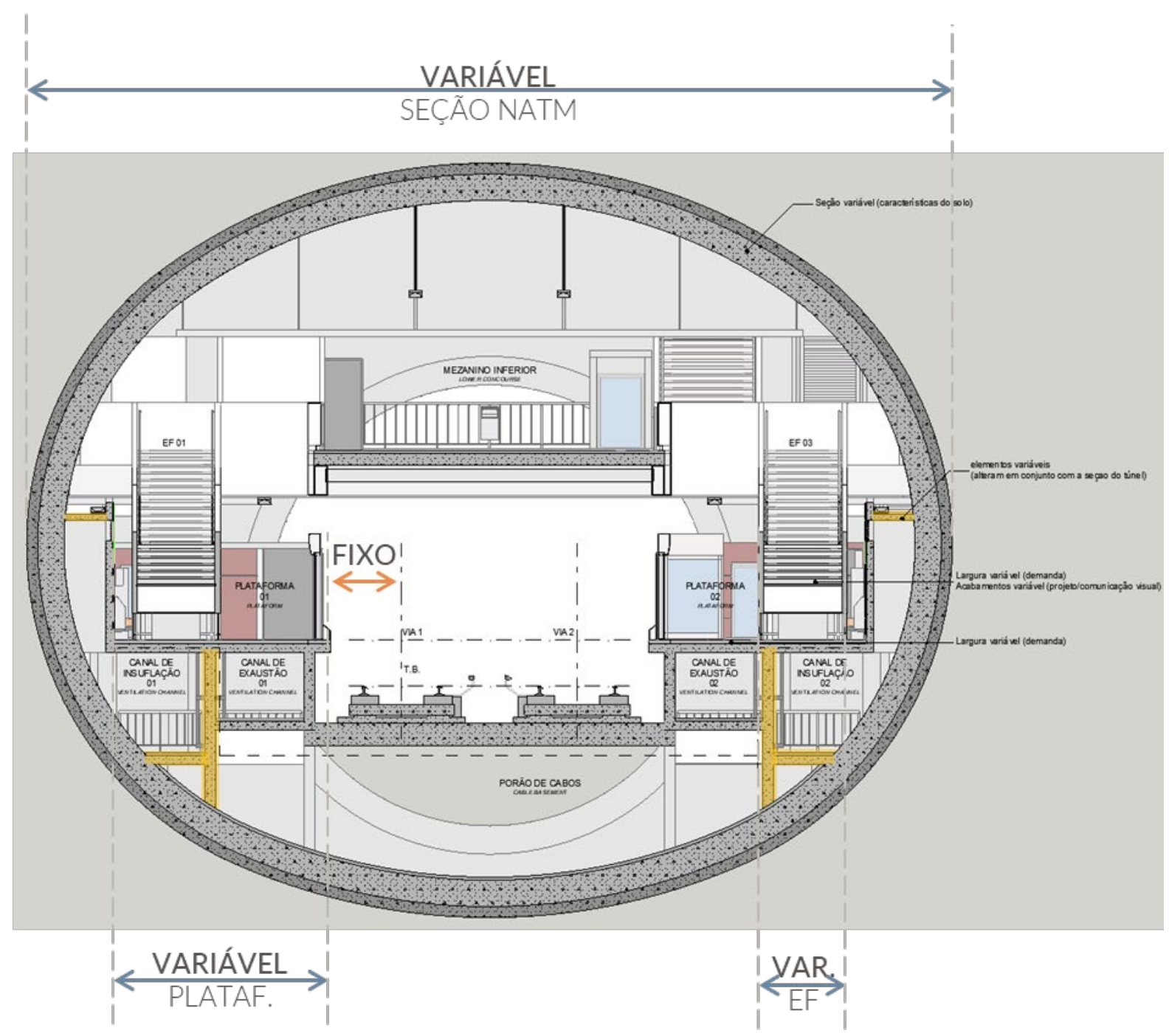

Fonte: Elaboração própria (2020). 
Os painéis de acabamento das plataformas devem permitir novas modulações, opções de cores e tipos de acabamentos. Lembrando que os materiais disponíveis no metacomponente deverão ser homologados pelo Metrô/SP, e estarem de acordo com todas as especificações técnicas exigidas. A Figura 73 apresenta uma imagem da plataforma, extraída do metacomponente desenvolvido.

Figura 73 - Imagem do metacomponente - Túnel NATM

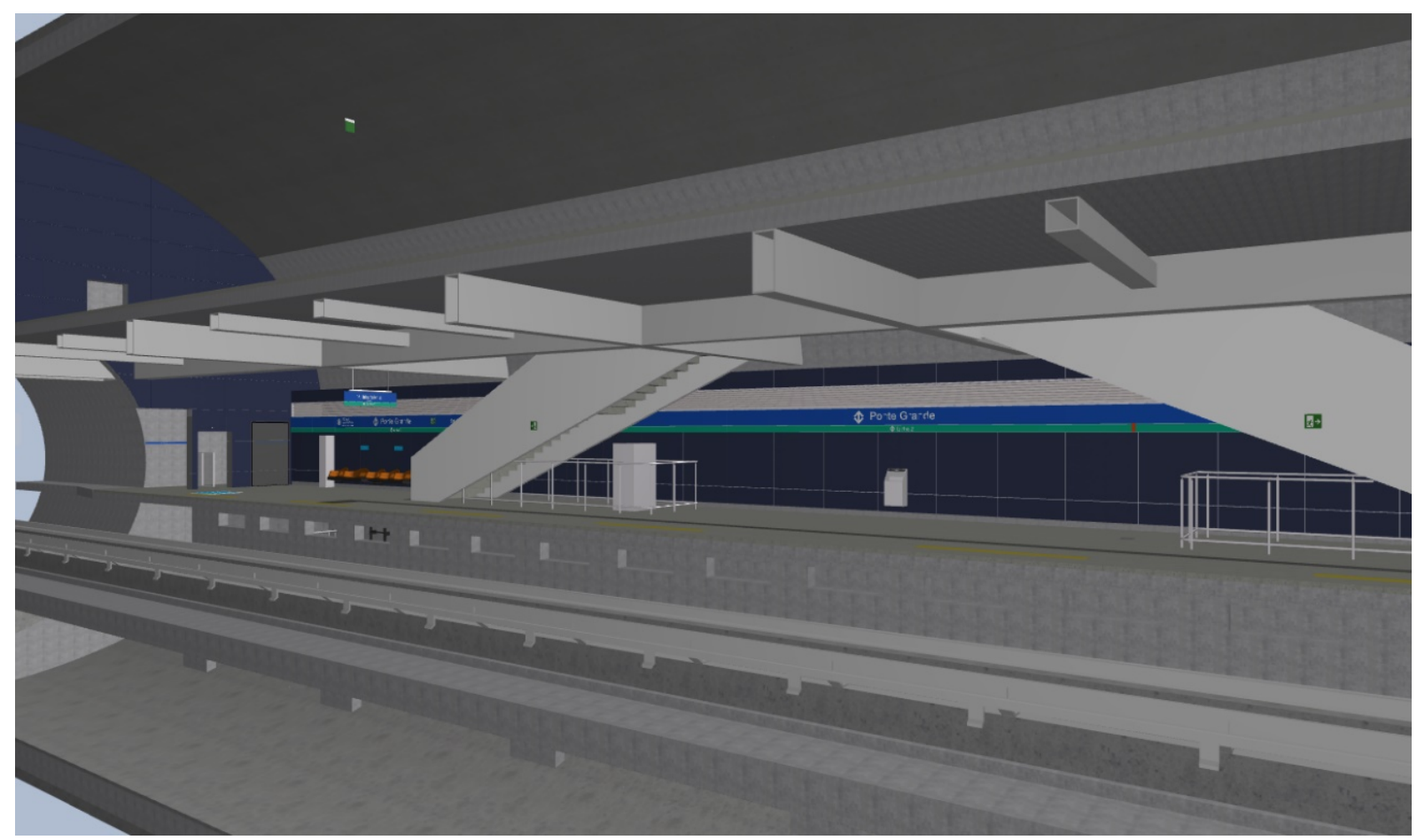

Fonte: Elaboração própria (2020).

Com relação ao poço central, conforme descrito nos pavimentos anteriores, o dimensionamento do conjunto: escada de emergência, sala de cabos, dutos de ventilação vertical e elevadores dará o diâmetro mínimo do poço. Entretanto, na plataforma e nos pisos acima há uma sala de equipamentos que também irá compor a dimensão do poço. Essa sala tem uma dimensão mínima para abrigar os equipamentos necessários. A Figura 74 ilustra a alteração no diâmetro do poço. 
Figura 74 - Poço central: parâmetros de dimensionamento

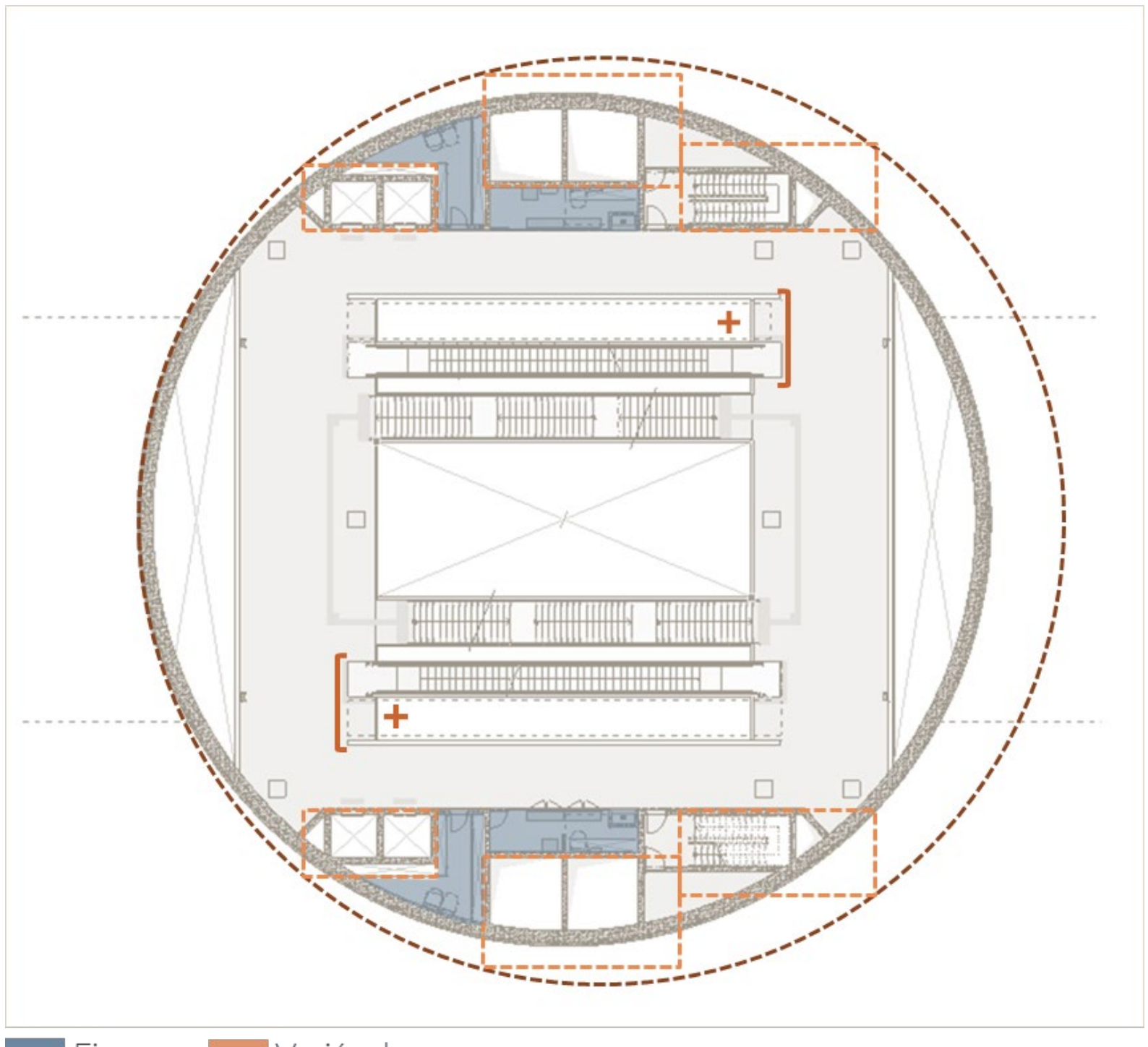

Fixo

Variável

Fonte: Elaboração própria (2020).

O Quadro 18 descreve os itens do pavimento que são variáveis, as suas relações e as regras necessárias para as alterações.

Quadro 18 - Plataforma: itens variáveis

\begin{tabular}{llll}
\hline Item & Variável & Relação & Regras para alteração \\
\hline Plataforma & Largura & _Demanda da estação & _Projeto básico túnel em \\
& & NATM; \\
& & \\
& - Ceção túnel NATM & Canal de ventilação & _Largura mínima \\
& - Largura da escada fixa & plataforma 5,00m \\
& &
\end{tabular}




\begin{tabular}{|c|c|c|c|}
\hline Item & Variável & Relação & Regras para alteração \\
\hline & & & $\begin{array}{l}\text { _Espaço mínimo livre } \\
2,50 \mathrm{~m} \text { da borda }\end{array}$ \\
\hline Escada fixa & $\begin{array}{l}\text { Largura, itens de } \\
\text { comunicação } \\
\text { visual (piso tátil e } \\
\text { sinalizadores), } \\
\text { guarda-corpo e } \\
\text { corrimão. }\end{array}$ & $\begin{array}{l}\text { _Demanda da estação } \\
\text { _ Seção túnel NATM } \\
\text { _Largura da plataforma }\end{array}$ & $\begin{array}{l}\text { _Cálculo: } 1.300 \mathrm{phd} \times \text { can }^{24} \\
\text { _Largura mínima }=1,80 \\
\text { _Altura degrau }=0,16 \mathrm{~m} \\
\text { _Largura degrau }=0,31 \mathrm{~m}\end{array}$ \\
\hline Escada rolante & $\begin{array}{l}\text { Número de } \\
\text { escadas rolantes }\end{array}$ & _Demanda da estação & $\begin{array}{l}\text { _Cálculo: 6.000phd x can } \\
\text { _Dimensionamento seguir } \\
\text { IP-9.00.00.00/3Z0-004; }\end{array}$ \\
\hline $\begin{array}{l}\text { Guarda-corpo de } \\
\text { proteção abaixo } \\
\text { das escadas (EF e } \\
\text { ER) }\end{array}$ & Comprimento & _Dimensão das escadas & $\begin{array}{l}\text { _Proteger até altura de } \\
2,10 \mathrm{~m}\end{array}$ \\
\hline Elevadores & $\begin{array}{l}\text { Largura e } \\
\text { comprimento }\end{array}$ & $\begin{array}{l}\text { _Estimativa de demanda } \\
\text { _Diâmetro do poço } \\
\text { central }\end{array}$ & $\begin{array}{l}\text { _Dimensão mínima } \\
\text { _Cálculo de tráfego }{ }^{25}\end{array}$ \\
\hline Piso tátil & $\begin{array}{l}\text { Posição em } \\
\text { relação aos } \\
\text { elevadores, mapa } \\
\text { tátil e segunda } \\
\text { porta do primeiro } \\
\text { carro. }\end{array}$ & $\begin{array}{l}\text { _Elevadores } \\
\text { _Mapa tátil }\end{array}$ & $\begin{array}{l}\text { _Afastamento mínimo de } \\
\text { obstáculos/paredes = } \\
\text { 1,00m } \\
\text { _Encaminhar p/ segunda } \\
\text { porta do primeiro carro } \\
\text { _Direcionar p/ botoeira dos } \\
\text { elevadores } \\
\text { _Traçado com ângulos }\end{array}$ \\
\hline
\end{tabular}

${ }^{24} \mathrm{~A}$ capacidade das escadas fixas deverá ser calculada em pessoas por hora pico (php) por canal de circulação em $0,60 \mathrm{~m}$ de largura (can).

25 Segundo critérios da NBR 5665/83, um elevador deve ser capaz de transportar de 6 a $15 \%$ da população total de um edifício em 5 minutos, portanto, o que determina o tamanho e a velocidade dele é o cálculo de tráfego. 


\begin{tabular}{|c|c|c|c|}
\hline Item & Variável & Relação & Regras para alteração \\
\hline & & & $\begin{array}{l}\text { retos ou a } 45^{\circ} \text { graus } \\
\text { _Utilizar piso de alerta } \\
\text { para mudar de direção }\end{array}$ \\
\hline $\begin{array}{l}\text { Escada de } \\
\text { emergência }\end{array}$ & $\begin{array}{l}\text { _Duto de } \\
\text { pressurização } \\
\text { (área) } \\
\text { _Largura }\end{array}$ & $\begin{array}{l}\text { _Demanda da estação } \\
\text { _Piso a piso do } \\
\text { pavimento }\end{array}$ & $\begin{array}{l}\text { _Cálculo: } 1.300 \mathrm{phd} \text { x can }{ }^{26} \\
\text { _Altura degrau }=0,16 \mathrm{~m} \\
\text { _Largura degrau }=0,31 \mathrm{~m} \\
\text { _Largura mínima }=1,20 \mathrm{~m}\end{array}$ \\
\hline
\end{tabular}

Duto de ventilação

\section{Sala de}

equipamentos

\begin{tabular}{|c|c|c|c|}
\hline Estrutura & $\begin{array}{l}\text { Paredes } \\
\text { estruturais, } \\
\text { pilares e vigas }\end{array}$ & _Diâmetro do poço & _Cálculo estrutural \\
\hline $\begin{array}{l}\text { Dimensão das } \\
\text { aberturas dos } \\
\text { canais de } \\
\text { insuflação }\end{array}$ & $\begin{array}{l}\text { Cálculos } \\
\text { específicos de } \\
\text { sistemas }\end{array}$ & _Painéis de revestimento & _Projeto Sistemas \\
\hline $\begin{array}{l}\text { Painel de } \\
\text { revestimento }\end{array}$ & $\begin{array}{l}\text { Acabamento e } \\
\text { modulação }\end{array}$ & $\begin{array}{l}\text { _Abertura canal de } \\
\text { insuflação } \\
\text { _CComunicação visual }\end{array}$ & \\
\hline Duto de ventilação & Seção & _Diâmetro do poço & _Projeto Sistemas \\
\hline Luminárias & Posição & _Largura da plataforma & \\
\hline
\end{tabular}

Fonte: Elaboração própria (2020).

${ }^{26} \mathrm{~A}$ capacidade das escadas fixas deverá ser calculada em pessoas por hora pico (php) por canal de circulação em 0,60m de largura (can). 


\subsubsection{Mezanino Inferior}

O Mezanino Inferior proposto no metacomponente possui estrutura metálica e se estende sobre a via permanente. A finalidade deste pavimento é distribuir os passageiros nas plataformas de embarque. A configuração do poço central é a mesma do pavimento inferior, com elevadores, sala de cabos, dutos de ventilação e escada de emergência, concentrados nas laterais do poço. As escadas que levam aos pavimentos superiores se localizam na parte central do poço. Nas extremidades do túnel NATM estão posicionadas as escadas fixas que levam à plataforma.

Assim como a plataforma, este é um pavimento de uso público que deve se adaptar as configurações visuais da linha no qual a estação será implantada. Assim, tanto os elementos de acabamento como os de comunicação visual devem oferecer ajustes e opções aos projetistas. Deste modo, os principais itens fixos do pavimento são o layout, o comprimento do mezanino e a dimensão dos equipamentos e mobiliário, conforme descrito no Quadro 19.

Quadro 19 - Mezanino Inferior: itens fixos

\section{Mezanino Inferior}

\section{Projeto Padrão (sem Justificativa \\ variável)}

Layout do pavimento A disposição dos espaços e equipamentos deve ser mantida para viabilizar metacomponente, inclusive com relação aos elementos das disciplinas de sistemas, instalações e estrutura.

\section{Comprimento e \\ O comprimento do mezanino inferior acompanha o tamanho das largura do mezanino plataformas que é fixado em $136 \mathrm{~m}$, em função do tamanho dos carros. E a (túnel NATM) largura do mezanino é a largura da via permanente, que também é fixada de acordo com os padrões técnicos dos carros.}


Mezanino Inferior

Projeto Padrão (sem Justificativa
variável)

Largura das prumadas A largura das prumadas tem dimensão mínima e fixa de $60 \mathrm{~cm}$, podendo ter de cabos do poço seu comprimento ser aumentado, dependendo das alterações do poço central central.

Largura do corredor No metacomponente a dimensão mínima de 1,20m da circulação será entre as prumadas de fixada.

cabos

$\begin{array}{ll}\text { Dimensão dos } & \text { Os componentes de mobiliário e equipamentos técnicos possuem } \\ \text { equipamentos e } & \text { dimensões padronizadas, e, portanto, fixas. Podendo sofrer ajustes em sua } \\ \text { mobiliário } & \text { posição. }\end{array}$

Fonte: Elaboração própria (2020).

O dimensionamento do poço central tem as mesmas variáveis da plataforma, somando as escadas fixas e rolantes que levam ao mezanino intermediário. A altura entre os mezaninos é um parâmetro importante para o dimensionamento das escadas e, consequentemente, para o diâmetro adequado do poço central. O Diagrama 4 apresenta as variáveis do pavimento e suas relações.

O dado de profundidade deve considerar a cota do saguão de entrada, que depende das cotas do terreno em que a estação será implantada, menos a cota do Topo do Boleto (TB), dada no projeto funcional pelo perfil da via permanente. É preciso lembrar que este número deve ser múltiplo de 0,16 por conta da regra das escadas fixas. Da profundidade total da estação devem ser descontadas as alturas fixas do metacomponente: TB para plataforma $(1,05 \mathrm{~m})$ e o piso a piso da plataforma $(4,32 \mathrm{~m})$. O valor restante deve ser dividido pelo um número de mezaninos e o resultado irá estabelecer a altura de piso a piso dos mezaninos intermediários e inferior. Os parâmetros do pavimento Mezanino inferior são descritos no Quadro 20. 
Diagrama 4 - Dados e parâmetros do Mezanino Inferior

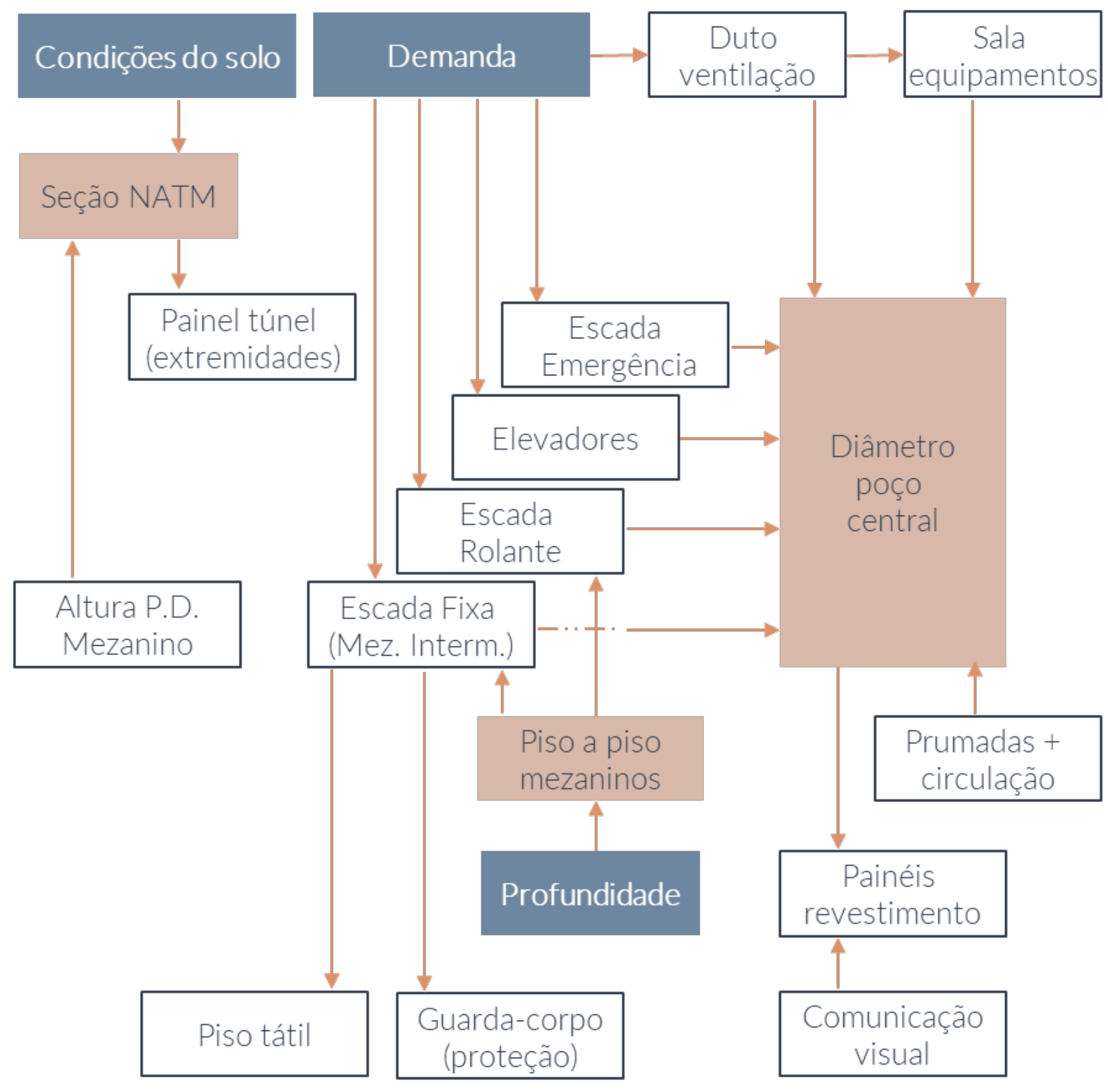

Dados de entrada

Dados de saída

Parâmetro

Fonte: Elaboração própria (2020). 
Quadro 20 - Mezanino Inferior: itens variáveis

\begin{tabular}{|c|c|c|c|}
\hline Item & Variável & Relação & $\begin{array}{l}\text { Regras para } \\
\text { alteração }\end{array}$ \\
\hline Mezanino Inferior & Altura & _Seção túnel NATM & $\begin{array}{l}\text { _Projeto básico túnel } \\
\text { em NATM; } \\
\text { _Largura mínima = } \\
\text { largura via permanente }\end{array}$ \\
\hline $\begin{array}{l}\text { Painel das } \\
\text { extremidades do } \\
\text { túnel NATM }\end{array}$ & Seção do painel & _ Seção túnel NATM & $\begin{array}{l}\text { _Projeto básico túnel } \\
\text { em NATM; }\end{array}$ \\
\hline Escada rolante & $\begin{array}{l}\text { _Número de escadas } \\
\text { rolantes; } \\
\text { _Comprimento e } \\
\text { altura. }\end{array}$ & $\begin{array}{l}\text { _Demanda da estação } \\
\text { _Piso a piso do } \\
\text { pavimento }\end{array}$ & $\begin{array}{l}\text { _Cálculo: 6.000phd x } \\
\text { can } \\
\text { _Dimensionamento } \\
\text { seguir IP- } \\
9.00 .00 .00 / 3 Z 0-004 \text {; }\end{array}$ \\
\hline $\begin{array}{l}\text { Guarda-corpo de } \\
\text { proteção abaixo das } \\
\text { escadas (EF e ER) }\end{array}$ & Comprimento & $\begin{array}{l}\text { _Dimensão das } \\
\text { escadas }\end{array}$ & $\begin{array}{l}\text { Proteger até altura de } \\
2,10 \mathrm{~m}\end{array}$ \\
\hline Elevadores & $\begin{array}{l}\text { Largura e } \\
\text { comprimento }\end{array}$ & $\begin{array}{l}\text { _Estimativa de } \\
\text { demanda } \\
\text { _Diâmetro do poço } \\
\text { central }\end{array}$ & $\begin{array}{l}\text { _Dimensão mínima } \\
\text { _Cálculo de tráfego27 }\end{array}$ \\
\hline Piso tátil & $\begin{array}{l}\text { Posição em relação às } \\
\text { escadas fixas. }\end{array}$ & _Escadas fixas & $\begin{array}{l}\text { _Afastamento mínimo } \\
\text { de obstáculos/paredes } \\
=1,00 \mathrm{~m} \\
\text { _ Traçado com ângulos } \\
\text { retos ou a } 45^{\circ} \text { graus } \\
\text { _Utilizar piso de alerta } \\
\text { para mudar de direção }\end{array}$ \\
\hline
\end{tabular}

27 Segundo critérios da NBR 5665/83, um elevador deve ser capaz de transportar de 6 a $15 \%$ da população total de um edifício em 5 minutos, portanto, o que determina o tamanho e a velocidade dele é o cálculo de tráfego. 


\begin{tabular}{|c|c|c|c|}
\hline Item & Variável & Relação & $\begin{array}{l}\text { Regras para } \\
\text { alteração }\end{array}$ \\
\hline $\begin{array}{l}\text { Escada de } \\
\text { emergência }\end{array}$ & $\begin{array}{l}\text { _Duto de } \\
\text { pressurização (área) } \\
\text { _Largura }\end{array}$ & $\begin{array}{l}\text { _Demanda da estação } \\
\text { _Piso a piso do } \\
\text { pavimento }\end{array}$ & $\begin{array}{l}\text { _Cálculo: 1.300phd } \mathrm{x} \\
\text { can } 28 \\
\text { _Altura degrau }= \\
0,16 \mathrm{~m} \\
\text { _Largura degrau }= \\
0,31 \mathrm{~m} \\
\text { _Largura mínima }= \\
1,20 \mathrm{~m}\end{array}$ \\
\hline
\end{tabular}

Sala de

equipamentos

\begin{tabular}{lll}
\hline Estrutura & _Paredes estruturais, _Diâmetro do poço_ _Cálculo estrutural \\
& pilares e vigas
\end{tabular}

\begin{tabular}{llll}
\hline Guarda-corpo & Material de Altura mín. \\
& acabamento, perfil e & & \\
& modulação. & \\
\hline
\end{tabular}

\begin{tabular}{|c|c|c|}
\hline $\begin{array}{l}\text { Painel de } \\
\text { revestimento }\end{array}$ & $\begin{array}{l}\text { Acabamento e } \\
\text { modulação }\end{array}$ & _Comunicação visual \\
\hline
\end{tabular}

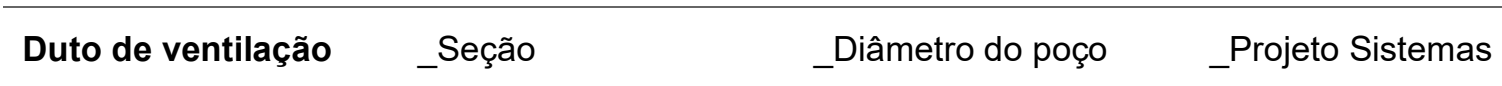

\begin{tabular}{ll}
\hline Luminárias $\quad$ Posição & Seção do túnel \\
& NATM
\end{tabular}

Fonte: Elaboração própria (2020).

\footnotetext{
${ }^{28} \mathrm{~A}$ capacidade das escadas fixas deverá ser calculada em pessoas por hora pico (php) por canal de circulação em 0,60m de largura (can).
} 


\subsubsection{Mezanino intermediário}

O Mezanino Intermediário é um pavimento destinado principalmente à circulação de usuários. Por ser um local público, os revestimentos devem ser variáveis para compor com a comunicação visual da linha na qual a estação será implantada. Assim como os níveis anteriores, o layout é definido pelo projeto padrão e o dimensionamento dos equipamentos e mobiliários é fixo. O Quadro 21 apresenta os itens fixos deste pavimento.

Quadro 21 - Mezanino Intermediário: itens fixos

\begin{tabular}{|c|c|}
\hline & Mezanino Intermediário \\
\hline $\begin{array}{l}\text { Projeto Padrão (sem } \\
\text { variável) }\end{array}$ & Justificativa \\
\hline Layout do pavimento & $\begin{array}{l}\text { A disposição dos espaços e equipamentos deve ser mantida para } \\
\text { viabilizar metacomponente, inclusive com relação aos elementos das } \\
\text { disciplinas de sistemas, instalações e estrutura. }\end{array}$ \\
\hline $\begin{array}{l}\text { Largura das prumadas } \\
\text { de cabos do poço central }\end{array}$ & $\begin{array}{l}\text { A largura das prumadas tem dimensão mínima e fixa de } 60 \mathrm{~cm} \text {, podendo } \\
\text { ter seu comprimento ser aumentado, dependendo das alterações do } \\
\text { poço central. }\end{array}$ \\
\hline $\begin{array}{l}\text { Largura do corredor } \\
\text { entre as prumadas de } \\
\text { cabos }\end{array}$ & $\begin{array}{l}\text { No metacomponente a dimensão mínima de } 1,20 \text { m da circulação será } \\
\text { fixada. }\end{array}$ \\
\hline $\begin{array}{l}\text { Dimensão dos } \\
\text { equipamentos e } \\
\text { mobiliário }\end{array}$ & $\begin{array}{l}\text { Os componentes de mobiliário e equipamentos técnicos possuem } \\
\text { dimensões padronizadas, e, portanto, fixas. Podendo sofrer ajustes em } \\
\text { sua posição. }\end{array}$ \\
\hline
\end{tabular}

Fonte: Elaboração própria (2020).

As variáveis deste pavimento estão diretamente relacionadas com 0 diâmetro do poço central. Os dados de estimativa de demanda dos passageiros na hora pico e a profundidade da estação balizarão o dimensionamento do pavimento. As principais variáveis deste nível são o conjunto de espaços nas laterais do poço, os equipamentos de circulação vertical e o corredor de passagem. A Figura 75 apresenta uma planta do pavimento destacando as variáveis mencionadas acima. 
Figura 75 - Mezanino Intermediário: parâmetros de dimensionamento

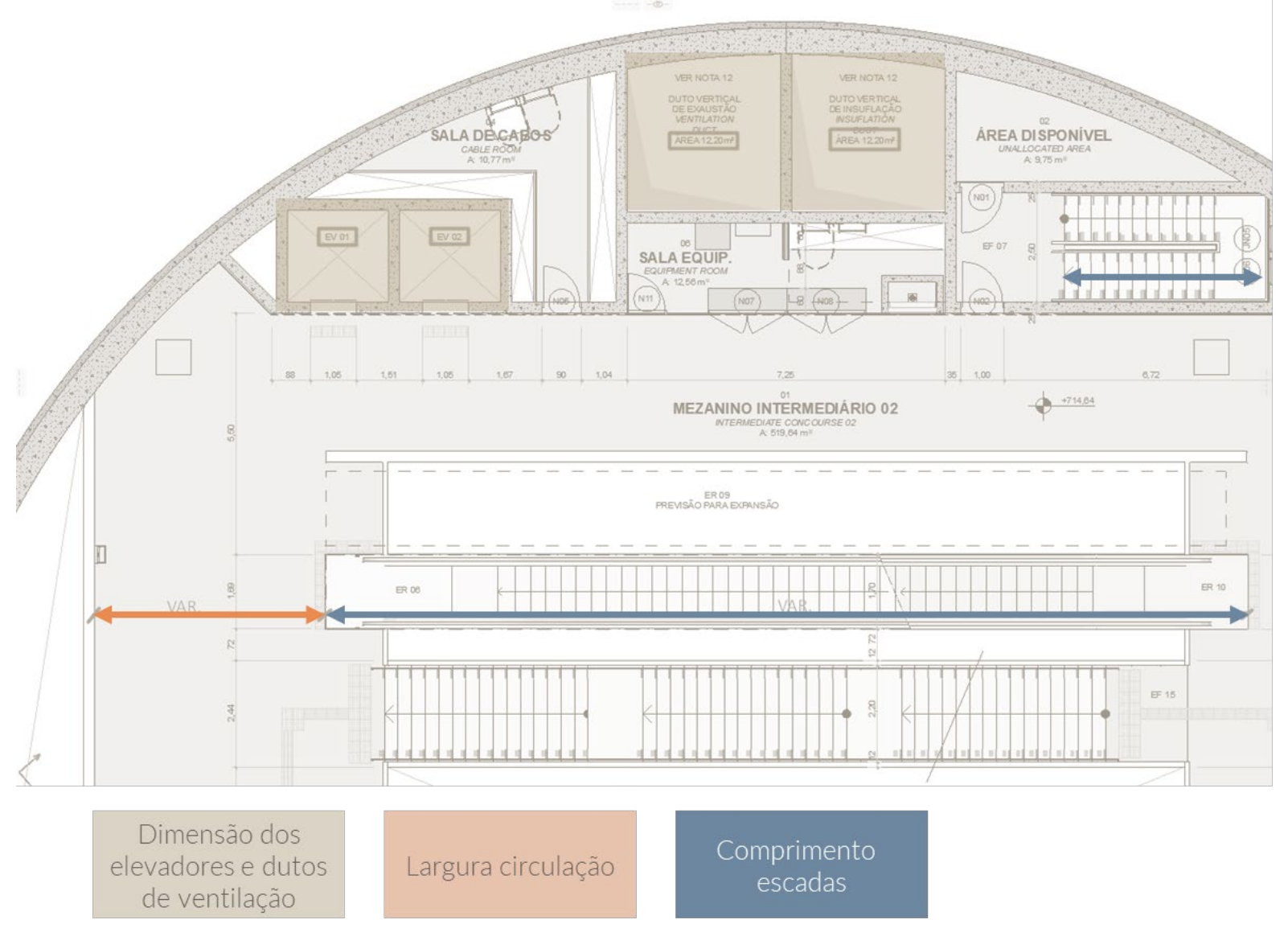

Fonte: Elaboração própria (2020).

O Quadro 22 descreve os itens variáveis do mezanino intermediário, apontando as regras e as relações para as alterações.

Quadro 22 - Mezanino Intermediário: itens variáveis

\begin{tabular}{llll}
\hline Item & Variável & Relação & Regras para alteração \\
\hline Escada rolante & _Número de escadas & _Demanda da & _Cálculo: 6.000phd x can \\
& rolantes & estação & _Dimensionamento seguir \\
& _Comprimento e altura. & _Piso a piso do & IP-9.00.00.00/3Z0-004; \\
& pavimento & \\
& &
\end{tabular}




\begin{tabular}{|c|c|c|c|}
\hline Item & Variável & Relação & Regras para alteração \\
\hline Elevadores & Largura e comprimento & $\begin{array}{l}\text { _Estimativa de } \\
\text { demanda } \\
\text { _Diâmetro do poço } \\
\text { central }\end{array}$ & $\begin{array}{l}\text { _Dimensão mínima } \\
\text { _Cálculo de tráfego29 }\end{array}$ \\
\hline Piso tátil & $\begin{array}{l}\text { Posição em relação as } \\
\text { escadas fixas. }\end{array}$ & Escadas fixas & $\begin{array}{l}\text { _Afastamento mínimo de } \\
\text { obstáculos/paredes }=1,00 \mathrm{~m} \\
\text { _ Traçado com ângulos retos }_{\text {ou a } 45^{\circ} \text { graus }} \\
\text { _Utilizar piso de alerta para } \\
\text { mudar de direção }\end{array}$ \\
\hline $\begin{array}{l}\text { Escada de } \\
\text { emergência }\end{array}$ & $\begin{array}{l}\text { _Duto de pressurização } \\
\text { (área) } \\
\text { _Largura }\end{array}$ & $\begin{array}{l}\text { _Demanda da } \\
\text { estação } \\
\text { _Piso a piso do } \\
\text { pavimento }\end{array}$ & $\begin{array}{l}\text { _Cálculo: } 1.300 \mathrm{phd} \times \text { can30 } \\
\text { _Altura degrau }=0,16 \mathrm{~m} \\
\text { _Largura degrau }=0,31 \mathrm{~m} \\
\text { _Largura mínima }=1,20 \mathrm{~m}\end{array}$ \\
\hline
\end{tabular}

\section{Sala de}

\section{equipamentos}

\begin{tabular}{llll}
\hline Estrutura & $\begin{array}{l}\text { _Paredes estruturais, } \\
\text { pilares e vigas }\end{array}$ & _Diâmetro do poço & _Cálculo estrutural \\
\hline Guarda-corpo & $\begin{array}{l}\text { Material de } \\
\text { acabamento, perfil e } \\
\text { modulação. }\end{array}$ & _Escada fixa & __Altura mín. \\
\hline $\begin{array}{l}\text { Painel de } \\
\text { revestimento }\end{array}$ & $\begin{array}{l}\text { Acabamento e } \\
\text { modulação }\end{array}$ & $\begin{array}{l}\text { _Comunicação } \\
\text { visual }\end{array}$ & \\
\hline $\begin{array}{l}\text { Duto de } \\
\text { ventilação }\end{array}$ & _Seção & _Diâmetro do poço & _Projeto Sistemas \\
\hline Luminárias & Posição & & \\
\hline
\end{tabular}

Fonte: Elaboração própria (2020).

${ }^{29}$ Segundo critérios da NBR 5665/83, um elevador deve ser capaz de transportar de 6 a $15 \%$ da população total de um edifício em 5 minutos, portanto, o que determina o tamanho e a velocidade dele é o cálculo de tráfego.

${ }^{30} \mathrm{~A}$ capacidade das escadas fixas deverá ser calculada em pessoas por hora pico (php) por canal de circulação em $0,60 \mathrm{~m}$ de largura (can). 
Os painéis de revestimento do poço central devem ser paramétricos quanto à paginação, tipo de material e cor. As portas dos ambientes devem acompanhar as demais variáveis. A Figura 76 apresenta um corte 3D do metacomponente desenvolvido, mostrando os painéis do poço central.

Figura 76 - Painéis de revestimento do poço central

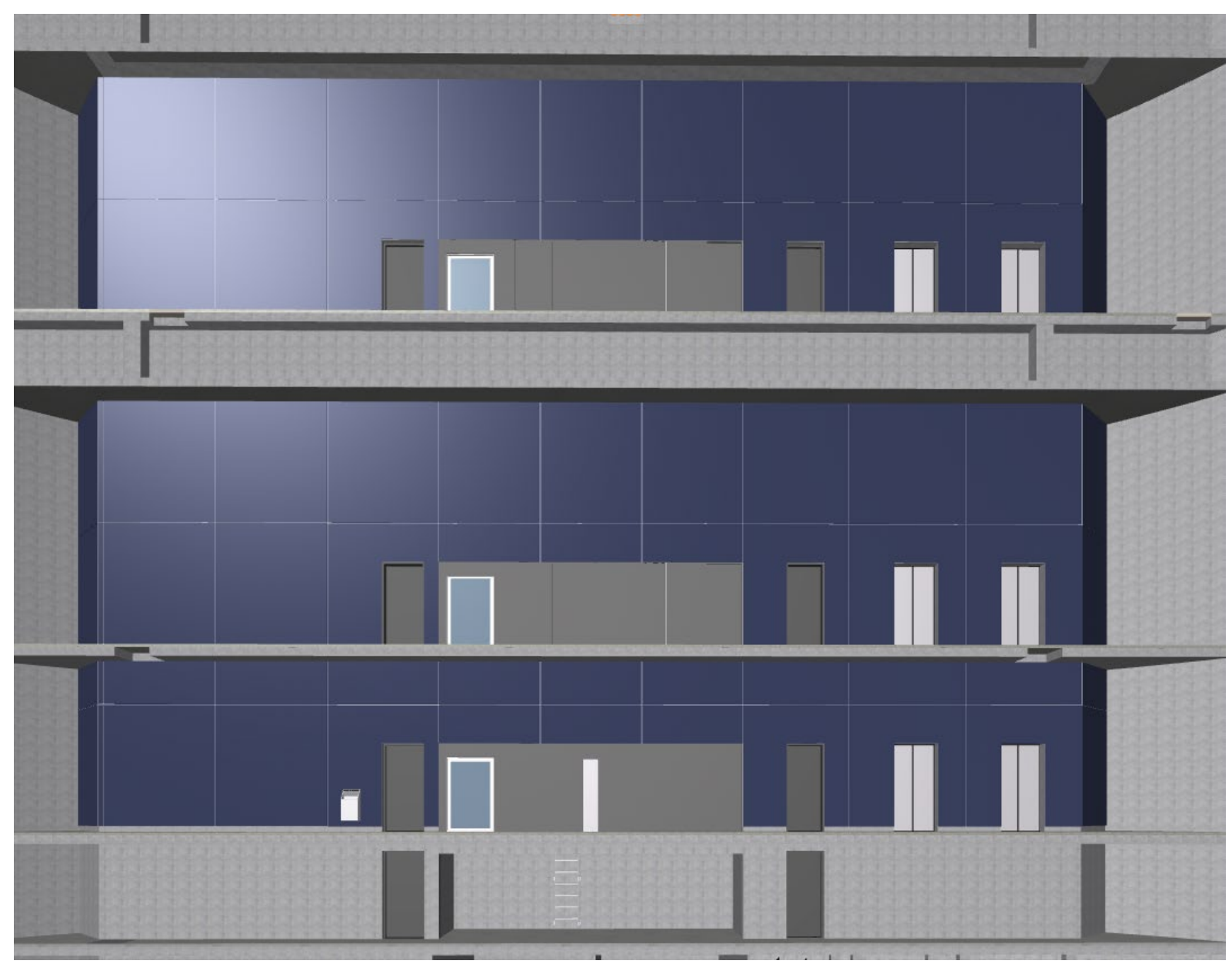

Fonte: Elaboração própria (2020).

Uma particularidade do mezanino intermediário é que ele pode ser replicado dependo da profundidade da estação. É importante lembrar que quanto menor forem as escadas rolantes, menor será o diâmetro do poço. Portanto, com o metacomponente, estudos de viabilidade comparando a quantidade de mezaninos intermediários com o diâmetro do poço, resultam em otimização do projeto e, consequentemente, do orçamento da estação. 
Conforme estudado nos pavimentos anteriores, cada parâmetro possui ligações com outras variáveis, o Diagrama 5 irá apresentá-las com o objetivo de esclarecer as conexões presentes no nível.

Diagrama 5 - Dados e parâmetros do Mezanino Intermediário

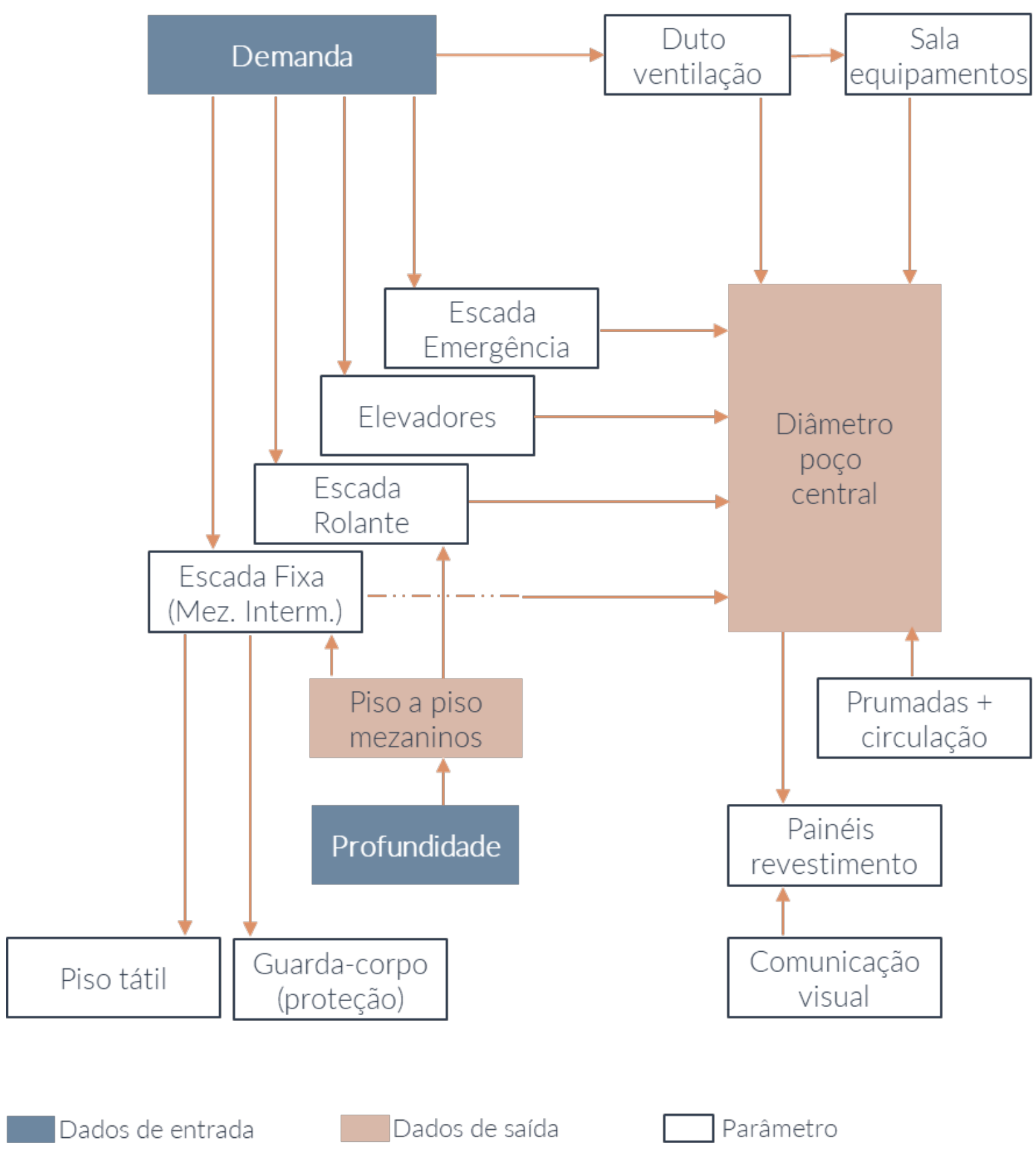

Fonte: Elaboração própria (2020). 
O diâmetro final do poço central deve ser escolhido em função do maior dimensionamento entre os pavimentos expostos.

\subsection{ORÇAMENTO}

A extração do orçamento do metacomponente é resultado da criação de propriedades específicas e da inserção de informações de custo nos componentes, somado à criação de tabelas para filtrar as informações essenciais de orçamentação.

Após modelar os elementos necessários para construção virtual do metacomponente, foram criadas as propriedades de orçamento: referência, código, preço unitário, unidade e total. Essas informações são necessárias para manutenção do metacomponente e para a extração do orçamento. As propriedades referentes ao "total" correspondem a uma expressão que calcula a quantidade multiplicada pelo preço unitário do componente.

É importante ressaltar que os elementos foram modelados com materiais de construção devidamente codificados ou, no caso dos equipamentos e mobiliários, a identificação foi feita através do ID do objeto. A Figura 77 apresenta a ferramenta materiais de construção com os acabamentos utilizados no modelo. Os códigos da CMSP foram especificados no ID do materia7, no campo "descrição" o material é detalhado e nos itens de orçamento são preenchidas as informações sobre a tabela de referência da qual foi extraído o preço do acabamento.

As tabelas de orçamento foram desenvolvidas por temas e pela unidade de medida do material/componente. Os temas são relativos à classificação utilizada pelo Metrô/SP para acabamentos, acessórios e caixilhos, conforme listado no Quadro 23. 
Figura 77 - Materiais de construção: itens de orçamento

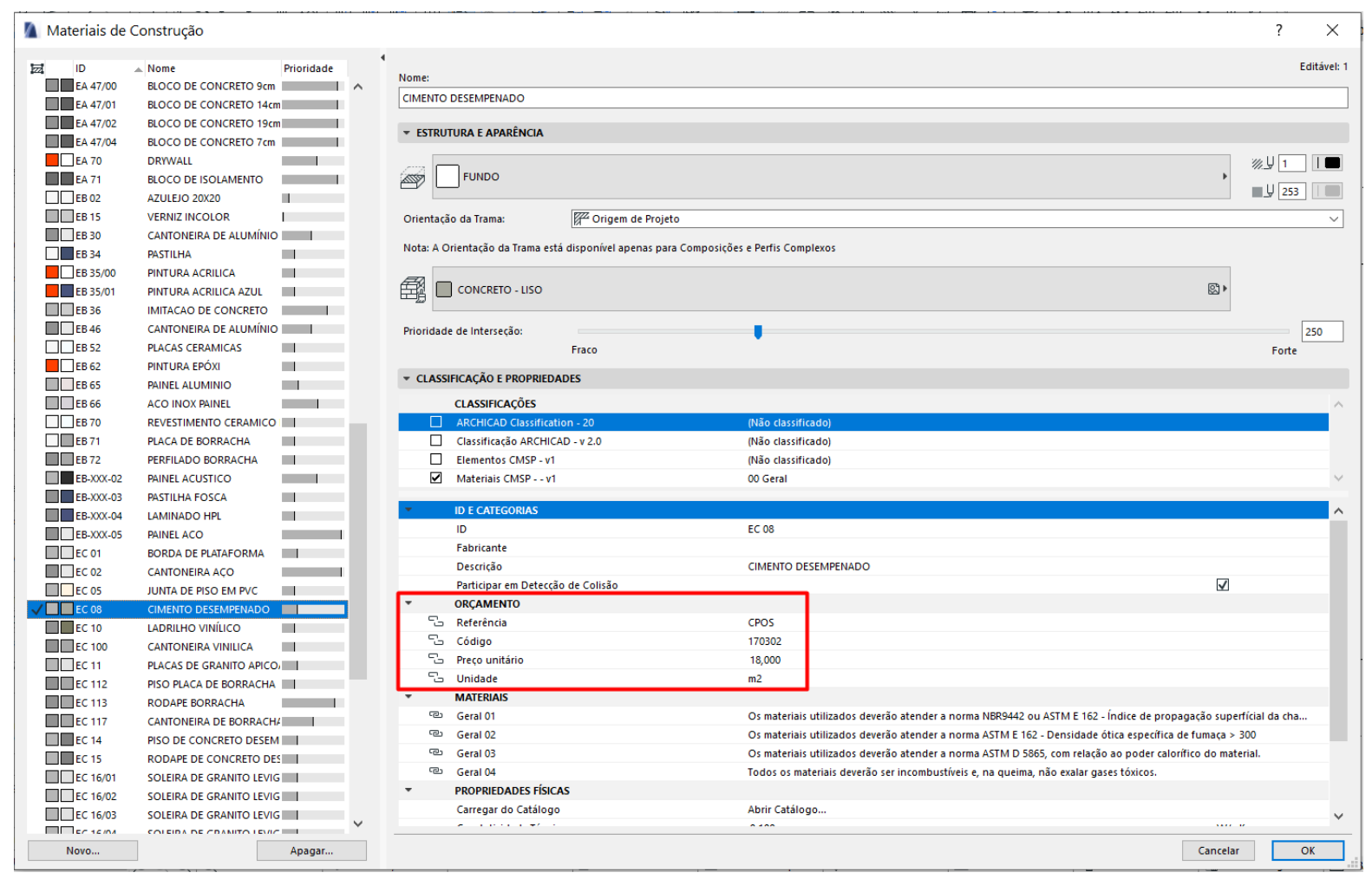

Fonte: Elaboração própria (2020).

Quadro 23 - Temas das tabelas de orçamento

\begin{tabular}{lc}
\hline EA & Alvenaria e complementos \\
\hline EB & Acabamentos verticais \\
\hline EC & Pisos e complementos \\
\hline ED & Acabamentos de tetos e forros \\
\hline EE & Acessórios e vedos \\
\hline EF & Acessórios de pisos \\
\hline EG & Peças e acessórios sanitários \\
\hline EH & Portas comuns \\
\hline EI & Portas e painéis especiais \\
\hline EJ & Caixilhos e janelas \\
\hline EK & Equipamentos \\
\hline EL & Cabines \\
\hline ES & Elementos especiais
\end{tabular}

Fonte: Relação de Elementos e Acabamentos - CMSP (2015). 
A divisão pode ser feita também por pavimento, caso seja necessário o estudo de algum nível especifico. A Figura 78 apresenta uma tabela de orçamento do tema "pisos e complementos" e unidade $\mathrm{m}^{2}$.

Figura 78 - OR: pisos $/ \mathrm{m}^{2}$

\begin{tabular}{|c|c|c|c|c|c|}
\hline \multicolumn{6}{|c|}{ OR - PISO (EC) } \\
\hline ID & Descrição & Área & Unidade & Preço unitário & Total (área) \\
\hline EC 08 & CIMENTO DESEMPENADO & $5.221,50$ & $\mathrm{~m} 2$ & 18,00 & --- \\
\hline EC 11 & PLACAS DE GRANITO APICOADO BRANCO PORTINARI $50 \times 50$ & 35,60 & $\mathrm{~m} 2$ & 302,00 & $-\ldots$ \\
\hline EC 14 & PISO DE CONCRETO DESEMPENADO DE ALTA RESISTENCIA & 153,78 & $\mathrm{~m} 2$ & 31.00 & -.. \\
\hline & & & & & \\
\hline EC 17 & PLACAS DE GRANITO LEVIGADO BRANCO PORTINARI $50 \times 50$ & $5.480,41$ & $\mathrm{~m} 2$ & 364,00 & $-\cdots$ \\
\hline EC 90 & PISO TÁTIL DE ALERTA DE PORCELANATO COR AZUL & 66,69 & $\mathrm{~m} 2$ & 302,65 &.-- \\
\hline FC 911 & PISO TÁTU DE AI FRTA DE PORCEIANATO CORAZIH & 0757 & 7 & 30205 & - \\
\hline & PISU TAIIL DE ALERIA DE PURCELAIVAIU CUK ALUL & & ImL & 302,93 & $\cdots$ \\
\hline & & & & & \\
\hline
\end{tabular}

Fonte: Elaboração própria (2020).

A relação entre os materiais/componentes e as tabelas de referência foi feita manualmente, item a item. Considerando que os valores são atualizados mensalmente, a revisão manual da propriedade "preço unitário" não é adequada. Sendo assim, é necessário criar um sistema automático de vinculação dos componentes aos preços. Em cada item foi identificada qual tabela foi utilizada como referência de preço e o respectivo código desta tabela, portanto a relação entre o item do metacomponente e a tabela já está estabelecido, faltando vincular os códigos a tabelas de referência atualizadas automaticamente. A Figura 79 ilustra os vínculos entre as propriedades de um elemento à planilha de orçamento e a sua respectiva tabela de referência.

Figura 79 - Propriedades e vínculos para orçamentação
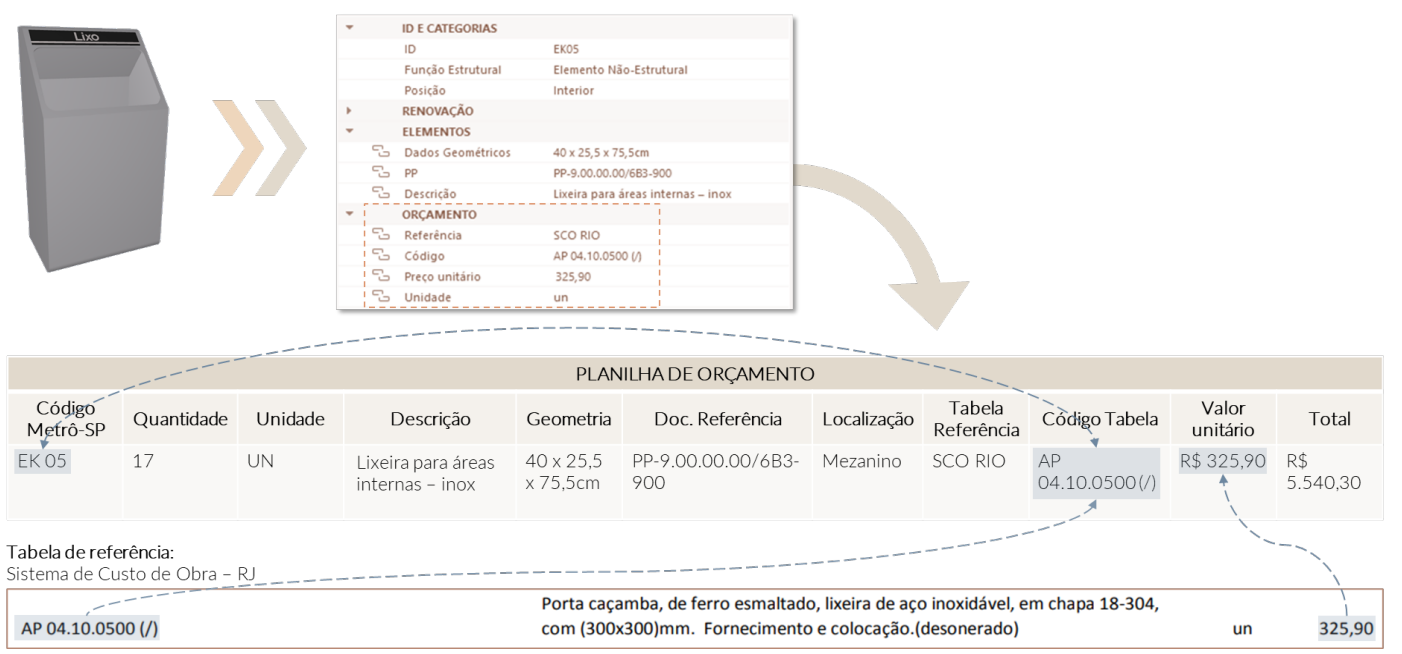

Fonte: Elaboração própria (2020). 



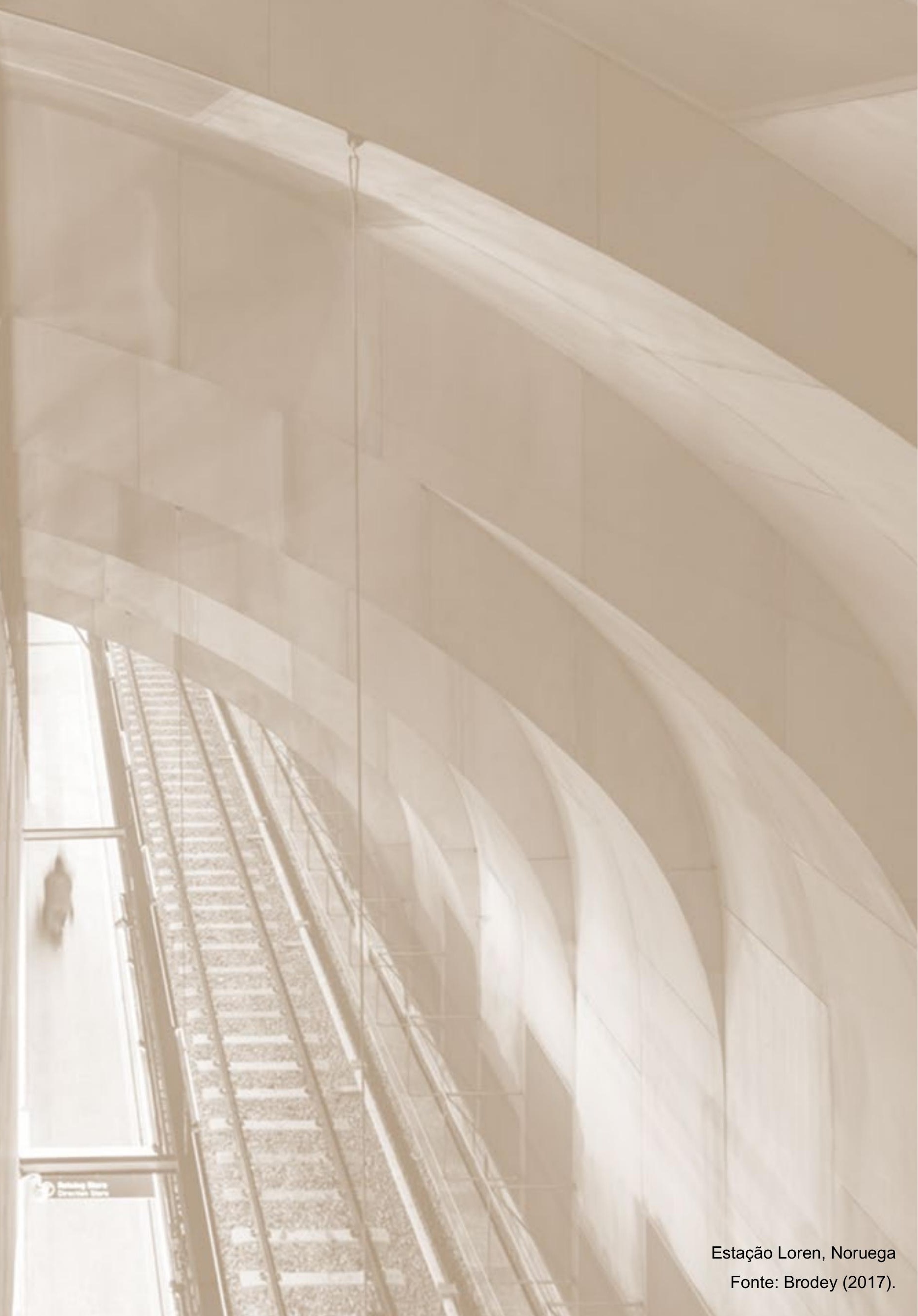


CAPÍTULO 5 | VALIDAÇÃO DA PROPOSTA 



\section{VALIDAÇÃO DA PROPOSTA}

Com o objetivo analisar criticamente o artefato desenvolvido, essa seção da pesquisa apresentará a validação da biblioteca de metacomponentes BIM para o Metrô/SP. A avaliação ocorreu de forma conceitual, uma vez que a pesquisa se limita a levantar os parâmetros para o desenvolvimento da biblioteca proposta.

Trata-se de uma pesquisa qualitativa com especialistas da área, com perguntas definidas e espontâneas, para demonstrar a utilidade e a viabilidade do artefato. Foram escolhidos três tipos de profissionais que trabalham diretamente com projetos metroviários, em diferentes áreas de atuação. A intenção é validar o artefato de três pontos de vistas diferentes: dos analistas e da gerência do Metrô/SP, e dos projetistas externos que desenvolvem os projetos para a Companhia.

O processo de entrevistas ocorreu da seguinte maneira: primeiramente foi realizado o contato com o especialista por e-mail, e após o aceite na participação da pesquisa, um vídeo explicativo foi envaido ao entrevistado, junto ao agendamento da entrevista on-line. O vídeo condensa em 15 minutos os principais pontos da pesquisa, ilustrando a utilização da biblioteca proposta, e apresentando o procedimento para validação da pesquisa. As entrevistas foram realizadas virtualmente, iniciando-se com a identificação dos entrevistados, passando pelos esclarecimentos sobre o trabalho, e depois para a aplicação da entrevista semiestruturada.

A identificação dos entrevistados busca levantar o tempo de experiência de cada especialista com os projetos de estações de metrô, sendo perguntada a formação do profissional, o cargo ou área de atuação, e o tempo de trabalho com projetos metroviários.

As questões discutidas nas entrevistas foram:

a) De acordo com a sua experiência, acredita ou atesta que a metodologia BIM pode melhorar o processo de projeto e contratação das obras públicas?

b) Qual sua opinião sobre as soluções de projeto padronizadas para partes específicas de estações metroviárias? 
c) Tem algum comentário ou opinião sobre a estrutura proposta para a biblioteca de metacomponentes BIM?

d) Acredita ser viável a construção de uma ferramenta de projeto que dimensione automaticamente, através de parâmetros, partes específicas das estações de metrô?

e) Em relação à fase de orçamentação, a proposta de conectar o metacomponente a tabelas de referências facilitaria e daria transparência ao processo licitatório?

f) Considerando o processo de projeto do Metrô/SP acredita que a utilização da biblioteca de metacomponentes proposta auxiliaria no desenvolvimento de projetos e na fase licitatória das obras metroviárias?

\subsection{ENTREVISTA “A”: PROJETISTA DO METRÔ/SP}

O entrevistado "A" atua no Metrô/SP desde 2012, com o desenvolvimento de projetos executivos como, por exemplo, o da expansão da linha 5-Lilás. Ele é mestre e doutorando pela FAU-USP, e em sua pesquisa de mestrado estudou sobre a padronização de estações metroviárias. Segundo o entrevistado, as estações subterrâneas são muito propícias para padronização, principalmente da disciplina de arquitetura, e considera interessante o ponto de vista da pesquisa que possibilita ajustes nos módulos padrão.

O entrevistado acredita que pela confiabilidade oferecida o BIM pode melhorar o processo de projeto das obras públicas. Como entusiasta da padronização das estações metroviárias percebe que a Companhia vem adotando este tipo de projeto como referência, principalmente para as futuras linhas de metrô. Constata que foi um processo de convencimento lento, mas que atualmente existem muitos movimentos dentro do Metrô/SP neste sentido, e que as linhas que estão sendo estudadas atualmente consideram a padronização desde o início. Relata, inclusive, que estuda uma nova linha trabalhando em uma proposta de estação 
padrão. Segundo ele, uma das metas do Metrô/SP em 2020 foi o desenvolvimento de projetos padronizados.

Sobre a estrutura da biblioteca, o projetista do Metrô/SP considera que os metacomponentes mais promissores são os que fazem interface com a malha urbana e podem ser inseridos no trecho mais superficial das estações, tratados na pesquisa como grupos $\mathrm{C}$ e $\mathrm{D}$. Acredita que quanto mais paramétricos e maleáveis forem esses módulos, melhor será a utilização junto aos projetos específicos de contenção rasa, viabilizando assim uma inserção urbana coerente das estações com a cidade.

Já em relação aos metacomponentes de estrutura de contenção profunda, o entrevistado "A" vê a possibilidade da criação de padrões escalonados, com alguns diâmetros fixos de poços e túneis, não sendo necessários módulos tão orgânicos e analógicos quanto aos propostos. De acordo com o entrevistado, os estudos das linhas surgem da pesquisa O/D (Origem/Destino) e do mapeamento de demanda à longo prazo. Sendo assim, as estações não são projetadas para uma demanda exata, sempre há uma margem para a dinâmica de evolução da cidade.

Questionado sobre um tratamento arquitetônico único para as estações, o arquiteto coloca que "o padrão é um retrato do momento". Cada novo projeto de linha pode alterar um eventual padrão estabelecido com o objetivo de atender às característica do seu tempo. E acrescenta, que quando se projeta uma linha ela imprime as marcas do período em que foi desenvolvida, de modo que o padrão não é estático, mas deve evoluir ao longo do tempo.

A linha de estudo sobre padronização desenvolvida pelo entrevistado surge do estudo das linhas existentes do Metrô/SP. O entrevistado "A" explica que a primeira linha construída pela Companhia (linha 1-Azul) tinha dois padrões bem claros: as estações subterrâneas de vala - no trecho Jabaquara-Liberdade, e as estações de superfície. Embora grande parte dessas estações seja padronizada, elas guardam diferenças entre si. O arquiteto Marcello Fragelli, responsável pelos projetos da linha, desenvolveu lajes de cobertura com volumetrias e desenhos diferentes para as estações subterrâneas, além da preocupação com a interface com a cidade. Neste sentido, o entrevistado não vê a padronização como um limite para individualidade de cada edificação, embora acredite também ser possível ter 
estações completamente padronizadas, como as criadas por Norman Foster para duas linhas subterrâneas em Bilbao, ilustradas na Figura 80 e na Figura 81.

Figura 80 - Acesso padrão, Linha 1 - Bilbao, Espanha

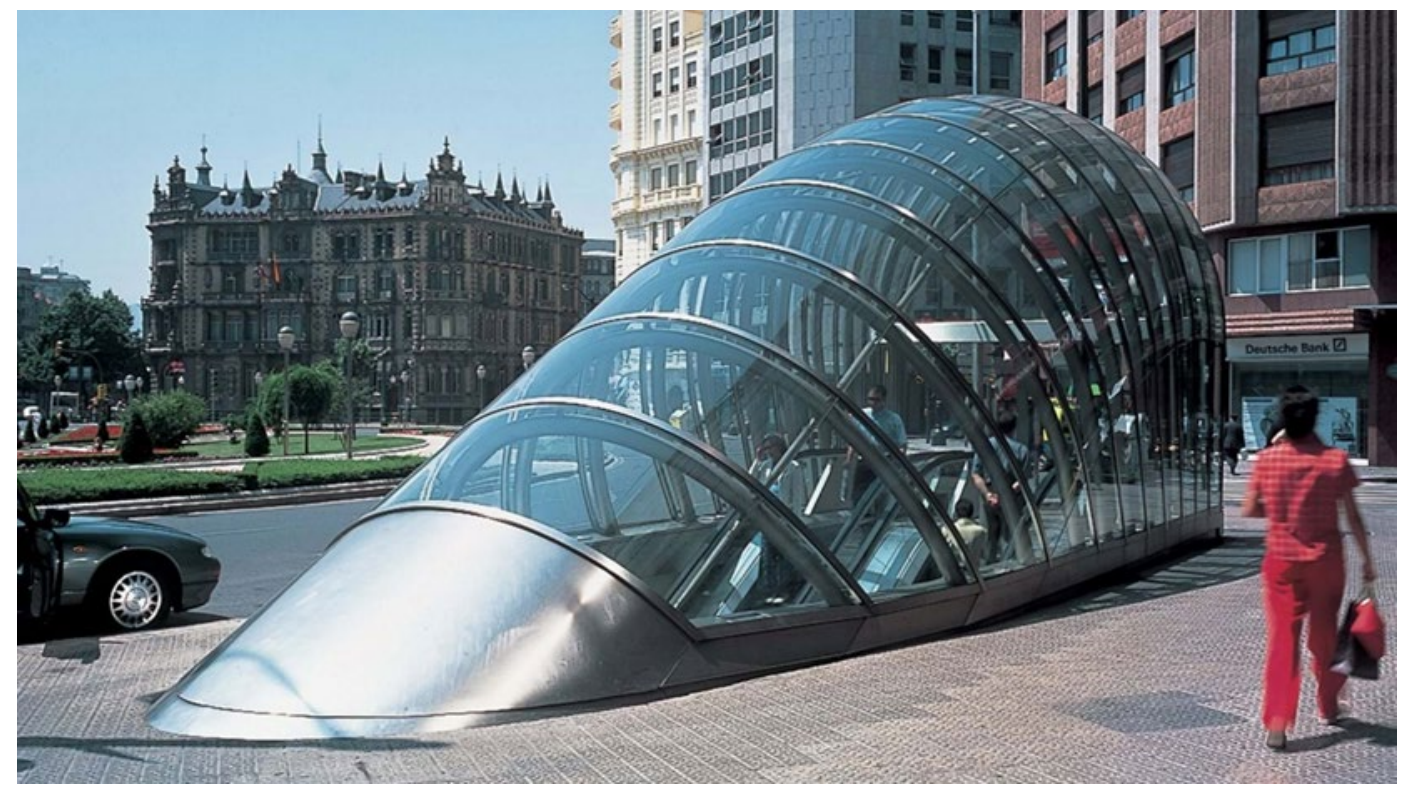

Fonte: Foster and Partners (1995).

Figura 81 - Estações em túnel projetadas por Norman Foster.

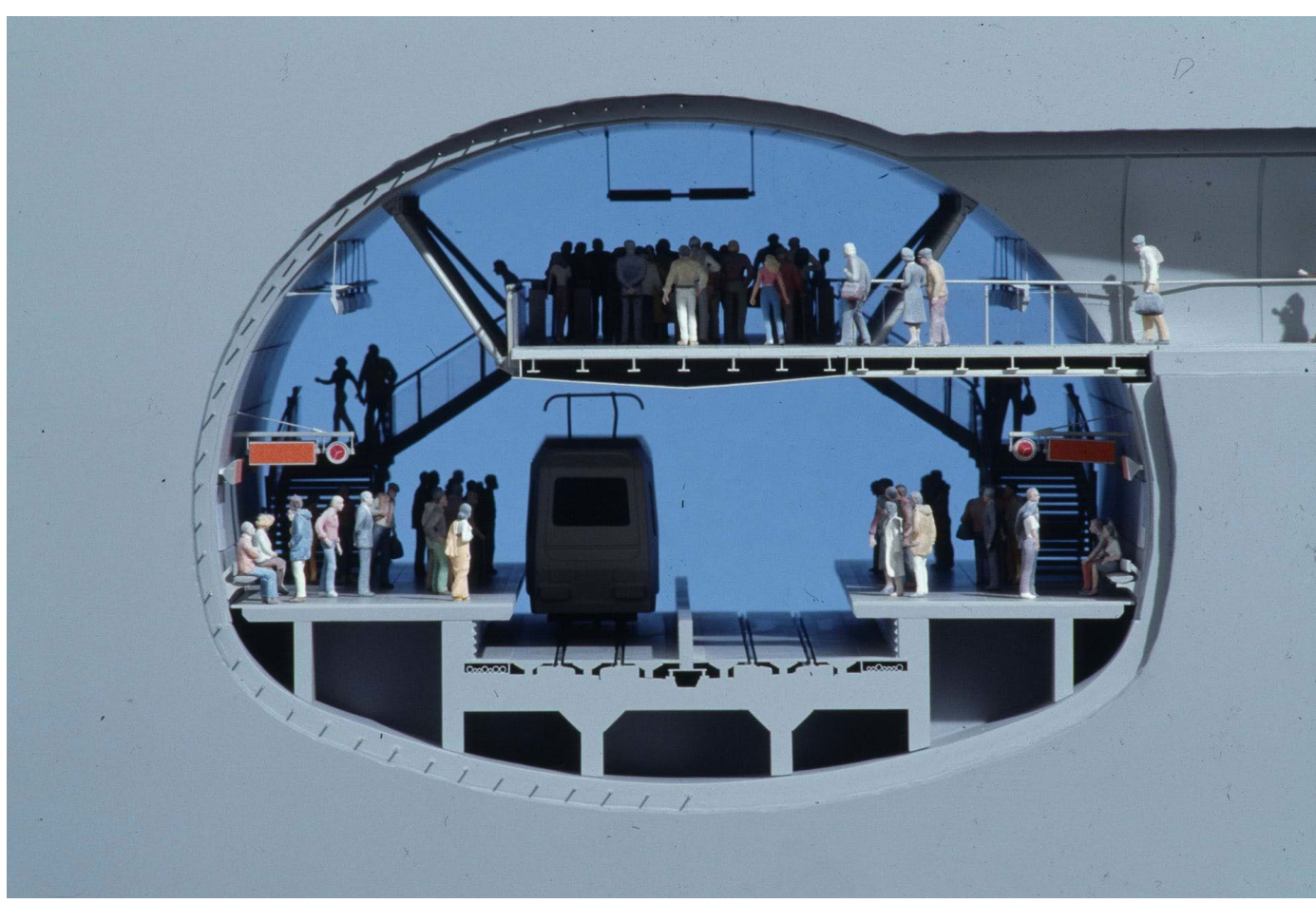

Fonte: Foster and Partners (1995). 
O entrevistado "A" coloca que ao se fazer um levantamento das críticas recebidas no Metrô/SP pelos projetos arquitetônicos, o foco é maior na relação com a cidade do que na parte interna das estações, local da proposta de padronização. Menciona também que grande parte dos trabalhos acadêmicos relacionados às obras do metrô, critica o impacto das edificações durante o período de obras ou a sua interface urbana. Destacando assim a importância em dedicar maior tempo do projeto na parte da articulação com a cidade.

Com relação à fase de orçamentação, o projetista entende que o fato de relacionar os componentes a planilhas de preço ajudaria no processo licitatório. Explica que os preços são dinâmicos, entretanto o que se tem nas licitações é um retrato do momento. Todos os ajustes monetários da obra serão executados a partir desta planilha, daí a importância de ter informações precisas e com descrições detalhadas dos elementos. Uma vez que o projeto é licitado e assinado, os valores iniciais variam, e o reajuste é feito a partir de critérios pré-definidos como, por exemplo, o B.D.I (Benefícios e Despesas Indiretas). Esse fator já considera todos os riscos que a contratada terá a partir do momento da licitação.

\subsection{ENTREVISTA "B": GESTORA DO METRÔ/SP}

A segunda entrevista foi realizada com a chefe do Departamento de Projeto de Arquitetura do Metrô/SP (Gerência de Projetos), que revela o ponto de vista do gestor sobre os temas levantados pela pesquisa. A entrevistada "B" é formada pela Unicamp, e trabalha no Metrô/SP desde 2009. Ela coloca que atualmente os prazos para a realização dos projetos e obras metroviárias estão cada vez mais exíguos e neste sentido, a questão da padronização está alinhada ao pensamento da Companhia.

A partir de 2018, para se adequar à lei 13.303, o Metrô/SP passou a desenvolver seu plano de negócios, reunindo diversas diretorias para discutir as metas da Companhia e, junto às áreas técnicas, aperfeiçoar o ciclo de vida dos empreendimentos. Neste momento, constataram que o prazo ideal para elaboração dos Projetos Básicos seria de mais de 30 meses, entretanto a gestora afirma que este tempo não é aceitável, considerando inclusive a questão da obsolescência das 
soluções propostas. Fazendo um estudo com aproximadamente 13 estações, o Departamento de Projetos chegou à estimativa de 20 meses para o desenvolvimento do Projeto Básico.

Para atingir esta meta, foi necessário pensar em formas para dinamizar e dar praticidade ao processo. O BIM veio ao encontro dessa intenção, aproximando a participação entre a projetista e o Metrô/SP, com ferramentas como o BIM Track e o BIM collab, ajudando a desburocratizar o processo de projeto. Já na parte técnica, sentiu-se a necessidade de encontrar padrões. A entrevistada relata que para as estações de integração é mais difícil, mas para projetos classificados com demandas de baixa a média, ou seja, até 12 mil usuários h/pico, é possível utilizar projetos padronizados.

A equipe de projetos do metrô/SP desenvolveu então, uma matriz de tipologias, com semelhanças à desenvolvida na presente pesquisa. A entrevistada comenta a importância dessa matriz com projetos já resolvidos quanto, por exemplo, às soluções das descidas de cabos, saídas de emergência, circulação vertical, etc. A partir da experiência da Companhia, em relação aos projetos já desenvolvidos, é possível estabelecer as melhores soluções, reduzindo o tempo com as discussões de projeto. Destacando assim a viabilidade do estudo em relação à possibilidade de despender maior tempo e intelecto na inserção urbana das estações. Indagada sobre a individualização dos projetos metroviários e a experiência dos usuários em cada estação, a entrevistada acredita que o foco dos projetos deve ser na segurança e conforto dos passageiros, e que o projeto padrão deve proporcionar espaço para que os projetistas atribuam qualidades a edificação, que melhorem a experiência do usuário. Segunda ela, isso pode ocorrer de diversas formas: especificando diferentes acabamentos, obras de arte, prevendo espaços comerciais, explorando a identidade visual da linha e tratando, principalmente, a superfície das estações.

A entrevistada "B" comenta que durante os estudos da linha 19, foi desenvolvido um projeto padrão em VCA, que será utilizado em seis estações desta linha, e também um projeto padrão em NATM. Assim como proposto na pesquisa, a parte das estruturas de contenções rasas são projetadas sob demanda, de acordo com a trama urbana local. 
Sobre a viabilidade da ferramenta proposta, a entrevistada coloca que, se é possível extrair projetos subterrâneos com a qualidade esperada, utilizando as regras e o conhecimento adquirido pela Companhia, não é um problema que seja feito por programação, desde que os ajustes e a inserção urbana sejam atribuídos aos profissionais da área.

No campo administrativo, a gestora do Metrô/SP faz uma reflexão sobre a forma como a proposta é colocada, a fim de não criar falsas expectativas. Conta que o Metrô/SP padronizou os projetos dos poços de ventilação e saída de emergência (VSE), desenvolvendo todas as disciplinas envolvidas como, por exemplo, hidráulica, estrutura, etc. Uma vez que o projeto padrão pronto, a expectativa era de apenas aplicá-lo aos locais desejados. Foi necessário então, defender a importância do tratamento das relações urbanas de cada poço.

Quanto à orçamentação, a entrevistada afirma que os objetos BIM desenvolvidos pelo Metrô/SP ainda não possuem relacionamento direto com tabelas de referência mas que os modelos BIM já estão ajudando nos levantamentos e orçamentos prévios, na fase de projetos diretrizes (etapa inicial). Acredita que extrair facilmente o orçamento dos modelos auxiliaria na tomada de decisão em relação à tipologia x custo-benefício das estações.

A entrevistada "B" finaliza a entrevista dizendo que vê com bons olhos a proposta da biblioteca de projetos padrão. Afirmando que é necessário evoluir o processo de projetos, tanto em relação aos prazos, quanto ao compromisso com o despende do dinheiro público.

\subsection{ENTREVISTA “C”: PROJETISTA EXTERNO}

O entrevistado "C" atuou onze anos como analista de projetos na CPTM, e desde 2008 desenvolve projetos de infraestruturas de transporte, projetando diversas estações para o Metrô/SP, coordenando, inclusive, o Projeto Básico da Estação Ipiranga, desenvolvido na metodologia BIM.

$\mathrm{O}$ arquiteto entrevistado acredita que o BIM pode melhorar o processo de projeto e contratação das obras públicas, mas aponta problemas com a falta de 
universalidade e abrangência das ferramentas, principalmente, em relação às disciplinas de engenharia civil, como estrutura, hidráulica, elétrica, etc.

Sobre a proposta da pesquisa, o projetista entende que quanto menor for a porção padronizada da edificação, mais simples será o processo, e menos limitações serão impostas pela ferramenta. Segundo sua visão, o risco é a ferramenta impor restrições às ideias e soluções de projeto. Cita, como exemplo, a escolha do NATM, no qual há diversos fatores locais que irão determinar a solução, como a geologia, as interferências, o método construtivo e também questões arquitetônicas mais subjetivas, como a entrada de luz nas estações ou a criação de jardins subterrâneos, por exemplo. Para o entrevistado "C" a condição do NATM é mais complexa pelas diversas possibilidades de arranjos e formas e, ainda, pela articulação com mais de um elemento. As vantagens de se poder usar uma ou outra solução é que se trata de um processo no qual vão sendo descartadas as opções menos vantajosas. Neste sentido, o entrevistado acredita que seria interessante uma ferramenta que facilitasse a validação de diferentes alternativas.

O entrevistado acredita que, ao se projetar uma nova linha em uma área no qual já se saiba a priori que é homogênea, pode-se pensar em uma solução padrão para esta linha, agilizando os estudos iniciais. Desta forma, o projeto da linha como um todo é o ponto de partida para desenvolver uma tipologia específica para a linha. Condição diferente, segundo ele, de se utilizar "soluções de prateleira" para encaixar em qualquer linha. Cita, como exemplo, o caso da Linha 9-Esmeralda da CPTM, onde se tem uma situação homogênea ao longo na Av. Marginal Pinheiros, e as estações possuem a mesma configuração: passarela de ligação para o acesso e plataformas entre a Av. Marginal e o rio Pinheiros. Mesmo neste caso, o projetista afirma que nenhuma estação é igual, mas acredita que seria possível aplicar uma biblioteca BIM padronizada em uma situação semelhante a esta.

Pensando em tipologias específicas para determinadas linhas com situações homogêneas, o entrevistado coloca que a principal vantagem é viabilizar um orçamento para a linha o mais próximo possível da realidade, em uma fase inicial de estudos, como o projeto funcional. Ainda assim, adverte que é necessário cuidado para não impor uma solução apenas porque ela é padrão, destacando a necessidade de verificar as condições do sítio, que muitas vezes são imprevisíveis. 
O entrevistado "C" diz que se sentiria mais confortável ao trabalhar com uma ferramenta para verificação do andamento dos projetos, que indicasse, por exemplo, os limites mínimos de áreas em cada ambiente, o atendimento às normas e parâmetros já estabelecidos, ou fizesse uma aferição das rotas de fuga e da acessibilidade dos projetos automaticamente. Alguns destes fatores são indicados na pesquisa como pontos importantes que podem ser atingidos com a biblioteca proposta e a modelagem dos projetos padrão.

A questão na demora entre as fases de projeto e a execução da obra, é lembrada pelo entrevistado, indicando que dentro deste período acontecem diversas alterações nos projetos por diferentes motivos como, por exemplo, ingerências políticas, estratégias econômicas, defasagem de tecnologias e legislação, e também questões comerciais, que acabam por dificultar o desenvolvimento e a execução de novas linhas de metrô. Portanto, quanto mais rápido for o processo melhor, mas priorizando sempre a qualidade dos projetos em detrimento dos prazos.

Com relação à estrutura proposta para a biblioteca, o entrevistado discorda da segmentação dos metacomponentes pelo trecho de implantação justificando que não é possível correlacionar os métodos construtivos à densidade urbana da cidade, ou ao tipo de relevo do local de inserção. Coloca também que a construção de uma tipologia pode agregar diferentes métodos construtivos.

Uma questão levantada pelo projetista em relação à biblioteca é que ela pode ser um repositório alimentado por novas soluções cada vez que desafios diferentes sejam impostos. Portanto, além dos módulos da biblioteca serem adaptáveis, eles devem permitir rearranjos que formem novos metacomponentes. Desta forma, a estrutura proposta para a biblioteca não é estática, abrindo assim a possibilidade da inserção de novos módulos, que podem ser utilizados em outras estações ou linhas.

Alinhado com o pensamento da pesquisa, o entrevistado "C" acredita que os acessos ou a parte superficial das estações é mais complexa e difícil de padronizar, sendo possível utilizar apenas módulos menores ou objetos padronizados na sua concepção. Destaca a importância das estações conversarem com o seu entorno e não apenas com o padrão estabelecido pela linha. 
Em relação ao grupo D, de setores individualizados, ou seja, locais como as salas técnicas e operacionais, o entrevistado concorda que, a partir de programas bem definidos e com parametrização, o uso dos metacomponentes auxiliaria no processo de projeto. Quanto à orçamentação, ele acredita que esse é o principal propósito do BIM atualmente e coloca que em termos de precisão e eficiência a metodologia pode contribuir para o processo. Porém, lembra que atualmente existem questões práticas em relação à modelagem que devem ser vencidas para se extrair orçamentos mais confiáveis.

Apesar de considerar um movimento arriscado, o entrevistado pondera que os metacomponentes padronizados e ajustáveis poderiam ser utilizados, desde que não restrinjam o potencial dos projetos e sejam bem avaliados quanto à inserção no contexto real. Destaca a validade da proposta nas fases iniciais do processo, pela contribuição da orçamentação atrelada aos planos governamentais, mesmo que nas etapas posteriores o projeto sofra grandes alterações. Outro caminho apontado é a utilização de blocos menores acoplados a projetos específicos, que permitam maior liberdade de criação em relação aos espaços.

Lembrando que os VSE's (poços de saída de emergência e ventilação) do Metrô/SP já são padronizados, o entrevistado constata que, de forma amplificada, a proposta da pesquisa se assemelha a esse processo. No desenvolvimento dos VSE's os projetistas recebem inicialmente projetos padronizados como exemplos, que devem ser trabalhados e alterados dependendo da situação e do local de implantação. No caso da pesquisa, esses exemplos e diretrizes seriam entregues em forma de modelo para serem desenvolvidos. O projetista pondera que os VSE's são edificações mais técnicas, e não possuem espaços de circulação pública, por esses motivos as variáveis diminuem, exceto na parte externa que também necessitam de uma integração com a trama urbana. 

CAPÍTULO 6 | CONSIDERAÇÕES FINAIS 



\section{6 | CONSIDERAÇÕES FINAIS}

A pesquisa nasce da constatação da dificuldade do poder público na administração das obras, junto à necessidade de expansão da rede de transportes metropolitanos. Mergulhando no processo de contratação e no desenvolvimento deste tipo de projeto percebe-se que grande parte dos problemas é gerada no início do processo, com projetos deficientes aliados a licitações imprecisas. O estudo teve como objetivo principal a discussão e proposição de soluções para a introdução de uma biblioteca de metacomponentes BIM no Metrô/SP. Neste item da pesquisa será exposto o que foi construído através do trabalho e as implicações dos resultados no campo prático.

Com base na metodologia adotada (DSR), a pesquisa foi estruturada em seis etapas: conscientização do problema, revisão da literatura, sugestão do artefato, desenvolvimento da biblioteca proposta, validação e conclusão do processo. A primeira fase compreendeu a identificação e a compreensão do problema levantado, com a definição do ambiente do estudo: o Metrô/SP. A segunda etapa da pesquisa consistiu em consultar a base de conhecimento existente, tanto teórica quanto prática. $\mathrm{Na}$ revisão bibliográfica foram pesquisados o processo licitatório de obras públicas, tecnologias BIM de forma geral, projeto assistido por algoritmos e bibliotecas BIM. Para levantar os processos existentes e as necessidades organizacionais, o capítulo três é destinado à área do problema, ou seja, ao Metrô/SP.

As questões estudadas sobre a contratação e legalização das obras públicas fundamentaram a pesquisa, tanto em relação às inconsistências do sistema quanto à importância da qualidade do projeto e das informações para o sucesso das licitações e, consequentemente, das obras. O estudo sobre as tecnologias de apoio ao processo de projeto auxiliou no desenvolvimento do artefato proposto, pois a partir do acesso aos termos e conceitos da metodologia BIM e de Projetos Assistidos por Algoritmos (AAD - Algorithm Aided Design) foi possível vislumbrar uma saída para o problema encontrado, através de uma ferramenta com metacomponentes BIM padronizados e parametrizáveis. 
A análise de algumas bibliotecas BIM existentes, tanto em versões privadas quanto públicas, teve como objetivo encontrar semelhanças e características para o desenvolvimento do artefato. A biblioteca estudada que mais se assemelhou à proposta da pesquisa foi a da FDE, que também é direcionada a edificações públicas, com um nicho específico de edificações educacionais. No entanto, esta biblioteca é restrita aos objetos BIM que compõem os modelos das escolas, diferente da proposta aqui desenvolvida, que é de agregações de componentes com padronização específica. De qualquer forma, o estudo de todas as bibliotecas BIM incorporou características e levantou questionamentos para a modelagem de metacomponentes apresentado na pesquisa.

Ainda na segunda etapa do estudo foi contemplado o processo de desenvolvimento de projetos no Metrô/SP e a situação da metodologia BIM na Companhia. Essa investigação revela que o processo tradicional de projeto é bastante burocrático, mas baseado em regras e parâmetros desenvolvidos pela Companhia ao longo da sua existência. A forma como o Metrô/SP desenvolve suas edificações, com uma série de itens padronizados e diretrizes bem estabelecidas, direciona a proposta da pesquisa, assim como dá subsídios para o desenvolvimento de metacomponentes. Mostra também a capacidade da Organização em trabalhar com projetos padronizados e com uma ferramenta que potencialize essa vertente, contribuindo para a redução dos prazos de projetos e a melhora na qualidade das licitações da Companhia.

$\mathrm{Na}$ terceira etapa, buscaram-se soluções práticas para agilizar o desenvolvimento dos projetos da Companhia, conferindo maior qualidade e controle no fluxo das informações. A sugestão proposta foi, então, aliar a metodologia BIM com a padronização dos projetos metroviários, desenvolvendo uma biblioteca de metacomponentes, com partes padronizadas das edificações modeladas, ricas em informações e que se ajustam parametricamente a diferentes situações.

De acordo com a metodologia adotada, a etapa seguinte foi o desenvolvimento e apresentação de um novo artefato que pode ser utilizado para solucionar as dificuldades com a qualidade dos projetos e os prazos de contratação do Metrô/SP. O capítulo quatro expõe, portanto, o desenvolvimento da biblioteca de metacomponentes BIM, iniciando pela estrutura da biblioteca e pelas principais 
características do artefato: utilização de projetos padronizados, objetos e soluções homologadas pelo Metrô, elementos e materiais vinculados às tabelas de referência e a parametrização dos metacomponentes. Neste momento, a pesquisa foca nas estações subterrâneas, por serem as mais utilizadas e com demanda crescente pelas condições restritas de construção na cidade.

Com o objetivo de discutir a modelagem e a estrutura dos arquivos de cada item da biblioteca foi apresentado o desenvolvimento de um metacomponente. A partir da criação deste módulo foram levantadas questões sobre a interação entre os elementos com a parametrização, assim como as características principais de cada componente e sua classificação, tendo como finalidade a utilização do modelo em diversos projetos.

A quinta etapa da pesquisa concentrou-se na avaliação da biblioteca BIM proposta em relação a sua utilidade e viabilidade, a fim de demonstrar sua validade, tanto imediatamente prática quanto como plataforma para desenvolvimentos acadêmicos. Sendo assim, foi desenvolvida e aplicada uma entrevista a profissionais da área metroviária. Antes da entrevista os profissionais receberam um vídeo que apresenta a proposta da pesquisa, simulando o processo de projeto com a utilização de um metacomponente. Foram realizadas cinco entrevistas e efetivadas três consultas com profissionais que trabalham em diferentes ramos na elaboração dos projetos de estações. A intenção foi avaliar o artefato a partir de diferentes pontos de vista, tanto dos analistas internos e da gerência do Metrô/SP, quanto de projetistas que desenvolvem externamente projetos para a Companhia.

A sexta etapa do estudo apresenta um extrato dos aprendizados construídos durante o desenvolvimento da pesquisa, os resultados obtidos e os itens que ainda podem ser aprofundados em trabalhos futuros.

O estudo sobre a padronização dos projetos metroviários apresentou inúmeros benefícios para questões relativas à diminuição dos custos e a maior confiabilidade dos orçamentos e controle dos prazos. Neste sentido, a pesquisa contribui para a adoção da metodologia BIM junto à padronização, com o objetivo de aprimorar o processo de projeto. A partir do estudo, essas duas vertentes se mostraram complementares e benéficas para a Companhia. No entanto, a validação da pesquisa levantou questões que podem indicar resistências às mudanças 
culturais propostas pelo trabalho como, por exemplo, a adoção de projetos padronizados e a utilização de um processo mais automatizado para a elaboração dos projetos das edificações.

É importante destacar que o processo de trabalho com a utilização da biblioteca facilita a escolha do método construtivo, uma vez que é possível testar vários modelos no terreno escolhido e ajustá-lo à situação do estudo como, por exemplo, a demanda de uso da estação e a sua profundidade específica. Como os componentes do módulo possuem informações de orçamentação, já em um primeiro momento, no projeto funcional, seria possível obter um orçamento preciso e detalhado do projeto em questão. Nas próximas fases do projeto, caso sejam requisitados ajustes particulares na estação, que a parametrização não consiga atender, é possível também desfazer os vínculos paramétricos do metacomponente e trabalhar como um modelo mais tradicional, ou seja, sem a segunda camada de parametrização atribuída. Sendo assim, mesmo em projetos especiais (não padronizados), a biblioteca de metacomponentes agiliza o processo de trabalho, uma vez que entrega modelos em arquivos estruturados e com componentes desenvolvidos. A Figura 82 apresenta um fluxograma com a utilização da biblioteca no processo de projeto.

Figura 82 - Exemplo de processo de projeto com a biblioteca proposta

\begin{tabular}{|c|c|c|c|c|c|}
\hline 1. IMPLANTAÇÃO & 2. DEMANDA & 3. PERFIL & 4. ESTRUTURA & 5. ARQUITEIURA & 6. ENTORNO \\
\hline $\begin{array}{l}\text { Definição do método } \\
\text { construtivo ou } \\
\text { projeto - padrão; } \\
\text { Aplicar o } \\
\text { metacomponente no } \\
\text { terreno selecionado. }\end{array}$ & 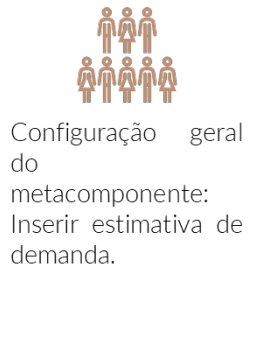 & $\begin{array}{l}\text { Configurar } \\
\text { metacomponente } \\
\text { verticalmente: inserir } \\
\text { cota do topo do } \\
\text { boleto e do saguão } \\
\text { de entrada. Estudar } \\
\text { melhor configuração. }\end{array}$ & $\begin{array}{l}\text { Dimensionamento } \\
\text { estrutural e de } \\
\text { ventilação. Inserir } \\
\text { dados dos cálculos } \\
\text { específicos. }\end{array}$ & $\begin{array}{lr}\text { Escolha de } & \text { de } \\
\text { acabamentos e itens } \\
\text { arquitetônicos } \\
\text { específicos. Inserir } \\
\text { dados de } \\
\text { comunicação visual } \\
\text { (alterar placas). }\end{array}$ & $\begin{array}{l}\text { Desenvolver projeto } \\
\text { das estruturas de } \\
\text { contenção rasas de } \\
\text { acordo com a trama } \\
\text { urbana local e } \\
\text { condições especiais } \\
\text { da estação. }\end{array}$ \\
\hline
\end{tabular}

Fonte: Elaboração própria (2021).

Apesar do estudo das estações metroviárias existentes confirmarem o uso de tipologias para determinados trechos das linhas, a partir das entrevistas com os profissionais da área contatou-se que é necessário aprofundar os estudos na direção dos metacomponentes ideais para composição da biblioteca, considerando principalmente os grupos com módulos mais completos das edificações. Estes 
metacomponentes, correspondentes aos grupos A, B e C, podem, por exemplo, ser menos parametrizados, diminuindo também o número de conflitos a serem administrados na ferramenta proposta. Segundo os entrevistados, é possível classificar as demandas das estações dentro de algumas tipologias, sendo desnecessário ajustes muito refinados de todas as medidas, conforme proposto neste estudo. Isso facilitaria a programação dos metacomponentes.

O grupo com metacomponentes de setores individualizados com partes menores das estações se mostrou mais eficiente quanto à sua utilização, à medida que pode ser facilmente vinculado a projetos específicos. Alguns desses módulos, mesmo em projetos 2D, já funcionam como blocos individualizados, como por exemplo os sanitários e a SSO, o que facilita também a compreensão da proposta para modelos tridimensionais. Esse grupo de metacomponentes apresenta programas bem definidos que com a parametrização poderiam ser ajustados às diferentes demandas ou situações.

A estrutura apresentada para a biblioteca pode ser complementada com novos métodos construtivos e configurações diferentes de tipologias à medida que estas forem requisitadas e desenvolvidas. A criação dos novos módulos deve ter como origem os metacomponentes existentes para que sejam aproveitadas as informações dos objetos e a estrutura dos arquivos.

Quanto ao desenvolvimento do metacomponente, uma das contribuições da pesquisa é levantar características de modelagem e propor algumas soluções, que são baseadas no software utilizado no estudo. Contudo, inicia-se uma discussão sobre os pontos críticos do modelo, estabelecendo também quais informações são relevantes para o processo, adiantando, desta forma, questões para futuras construções digitais, mesmo que sejam utilizadas ferramentas diferentes.

Os campos de classificação e propriedades criados para os componentes auxiliam tanto na orçamentação, quanto no relacionamento das regras e diretrizes do Metrô/SP aos itens específicos. Contribui-se assim para concentrar os conhecimentos da companhia no modelo e estrutura-se, desta forma, um processo de trabalho mais ágil e preciso. No entanto, o estudo sobre a atualização dessas informações deve ser aprofundado, buscando formas automatizadas para verificação e revisão das mesmas. É necessário também elaborar formas de integrar todos os 
metacomponentes da biblioteca, para que as informações estejam sempre compatíveis entre todos os modelos.

Outra contribuição da pesquisa é a classificação das regras e diretrizes do Metrô/SP e a aplicação das mesmas no metacomponente. A partir desta classificação, foi possível estabelecer parâmetros para o modelo desenvolvido. O estudo sobre a parametrização remete à criação de uma ferramenta de projeto assistido por computador, no qual seria possível otimizar o trabalho dos projetistas e analistas ao adaptar os módulos da biblioteca através de diversas variáveis e relações pré-estabelecidas.

Ao estudar cada pavimento do metacomponente, foi possível observar os itens variáveis e fixos do layout proposto e estabelecer as relações entre os ambientes e componentes do projeto. Com o estudo realizado é possível perceber inúmeras interrelações e discutir sobre a mediação dos conflitos encontrados. A partir das considerações dos entrevistados na validação da pesquisa identificam-se formas para simplificar as divergências como, por exemplo, o dimensionamento do metacomponente a partir de degraus de demandas fixas. Neste caso, as variações ocorreriam principalmente por conta dos detalhes construtivos e da profundidade das estações, não sendo necessária a criação de módulos completamente ajustáveis, o que diminuiria a complexidade entre as relações de espaços e componentes.

A tarefa de automatizar modelos BIM se mostrou bastante complexa. No entanto, a contribuição da pesquisa concentra-se em despertar para soluções inovadoras que visam melhorar o desenvolvimento dos projetos, conferindo mais qualidade e controle das informações. É possível e necessário encontrar meios que proporcionem menores prazos ao processo de projetos, melhorando, consequentemente, a velocidade de expansão da rede metropolitana de transportes.

A pesquisa levanta dados importantes sobre o processo de projeto no Metrô/SP e oferece caminhos para a inovação. Espera-se que o trabalho realizado incentive o desenvolvimento de novos estudos no âmbito dos projetos metroviários ou em outras áreas públicas que produzam edificações similares como, por exemplo, a saúde e a educação. 


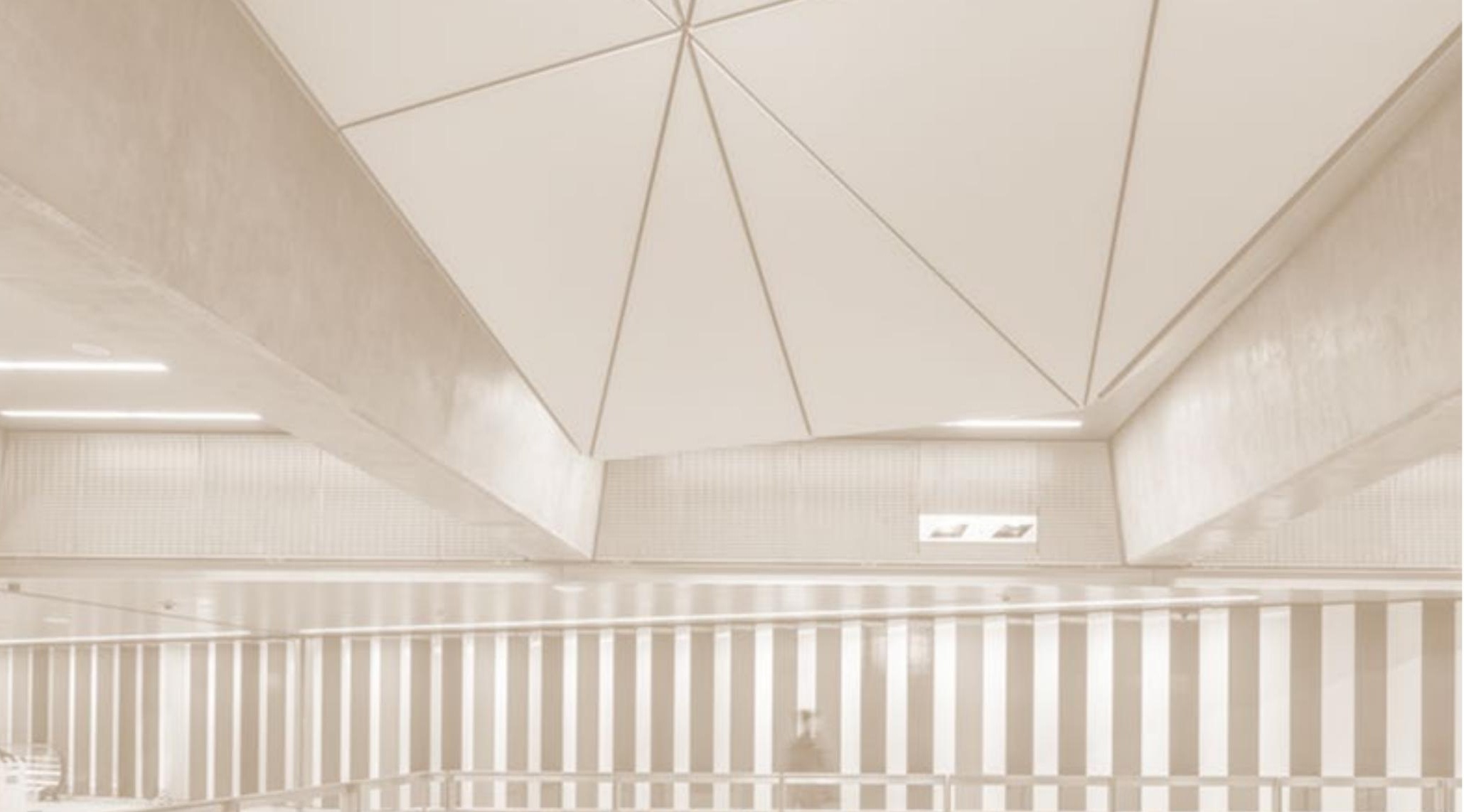

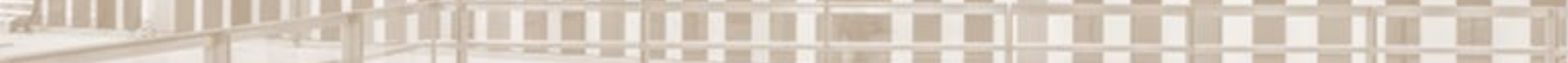

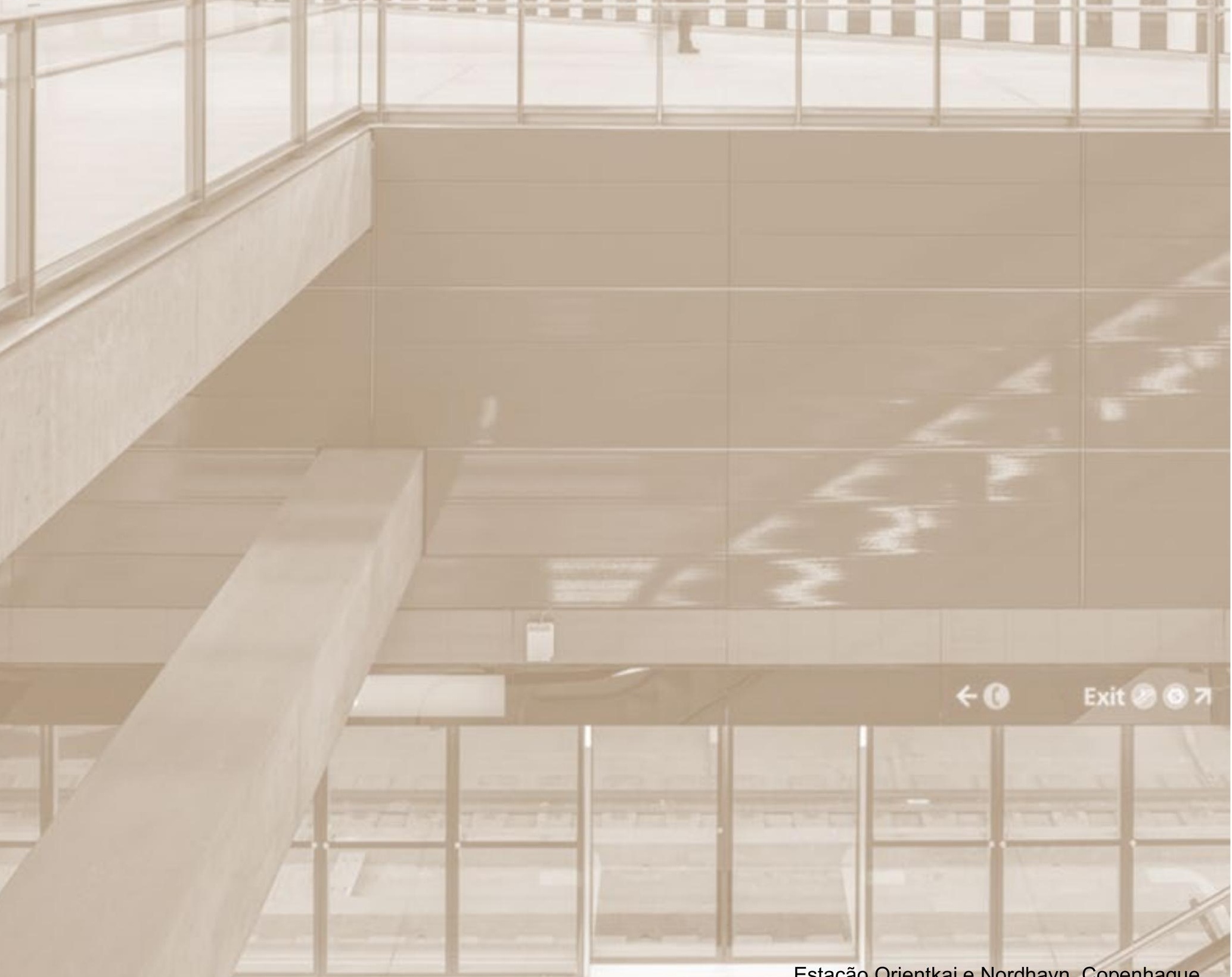

Estação Orientkaj e Nordhavn, Copenhague,

Fonte: Hjortshoj (2020). 


\section{REFERÊNCIAS BIBLIOGRÁFICAS}





\section{REFERÊNCIAS BIBLIOGRÁFICAS}

AGÊNCIA BRASILEIRA DE DESENVOLVIMENTO INDUSTRIAL - ABDI. BIM na Quantificação, orçamentação, planejamento e gestão de serviços da construção. Brasília-DF: ABDI, 2017a. (Coletânea Guias BIM ABDI-MDIC).

AGÊNCIA BRASILEIRA DE DESENVOLVIMENTO INDUSTRIAL - ABDI. Processo de Projeto BIM. Brasília-DF: ABDI, 2017b. (Coletânea Guias BIM ABDI-MDIC).

AGÊNCIA CÂMARA. Livro aponta 14 mil obras públicas paradas; custo até agora é de R\$ 70 bi. 2019. Agência Câmara, Brasília, 15 out. 2019. Disponível em: https://www.camara.leg.br/noticias/599773-LIVRO-APONTA-14-MIL-OBRAS-

PUBLICAS-PARADAS;-CUSTO-ATE-AGORA-E-DE-R\$-70-BI. Acesso em: 17 nov. 2019.

ALESSI, Gil. 'Trensalão' e Furnas: o lento desenrolar dos escândalos tucanos na Justiça. . El País, São Paulo, 21 fev. 2016. Disponível em: https://brasil.elpais.com/brasil/2016/02/19/politica/1455891750_478342.html. Acesso em: 6 fev. 2021.

ALTOUNIAN, C.S. Obras públicas: licitação, contratação, fiscalização e utilização. Belo Horizonte: Fórum, 2016.

ARCHSOLO. LINHA 5 LILÁS - METRÔ SP. 2021. Disponível em: http://www.archsolo.com.br/portfolio-item/linha-5-lilas-metro-sp/. Acesso em: 6 fev. 2021.

ASSOCIAÇÃO BRASILEIRA DE NORMAS TÉCNICAS - ABNT. NBR 9284: Equipamento Urbano. São Paulo: ABNT, 1986. 4 p.

ASSOCIAÇÃO BRASILEIRA DE NORMAS TÉCNICAS - ABNT. NBR 5665: Cálculo do tráfego nos elevadores. São Paulo: ABNT, 1987.

ASSOCIAÇÃO BRASILEIRA DE NORMAS TÉCNICAS - ABNT. NBR ISO 12006-2: Construção de edificação - Organização de informação da construção - Parte 2: Estrutura para classificação de informação. São Paulo: ABNT, 2018. 
BESSONI, Artur. Contexto BIM no Brasil e no Mundo. Bim Experts, 2 jan. 2019. Disponível em: http://bimexperts.com.br/contexto-bim-no-brasil-e-no-mundo/. Acesso em: 21 ago. 2018.

BIM OBJECT. Catálogo de objetos BIM. 2019. Disponível em: https://www.bimobject.com. Acesso em: 20 mar. 2021.

BIM TOOL. Catálogo de objetos BIM. 2019. Disponível em: https://www.bimtool.com. Acesso em: 20 mar. 2021.

BIM DICTIONARY. Level of Development (LOD). 2020. Disponível em: https://bimdictionary.com/terms/search. Acesso em: 22 set. 2020.

BORMOTIN, Alexandr. Metrostation Savelovskaya, Moscow. 2020. Disponível em: https://www.instagram.com/p/B6Nrg25liKt/. Acesso em: 16 mai. 2021.

BRASIL. Controladoria Geral da União - CGU. Licitações e contratações. Portal da Transparência. Disponível em: http://www.portaltransparencia.gov.br/entenda-agestao-publica/licitacoes-e-contratacoes. Acesso em: 8 ago. 2019.

BRASIL. Ministério do Planejamento, Desenvolvimento e Gestão. Painel de Obras. Brasília-DF, 24 abr. 2018. Disponível em: http://paineldeobras.planejamento.gov.br/. Acesso em: 5 ago. 2018a.

BRASIL. Presidência da República. Casa Civil. Lei nº 8.666, de 21 de junho de 1993. Regulamenta o art. 37, inciso XXI, da Constituição Federal, institui normas para licitações e contratos da Administração Pública e dá outras providências. Diário Oficial [da] República Federativa do Brasil, Poder Legislativo, Brasília, DF, 22 jun. 1993.

BRASIL. Presidência da República. Casa Civil. Lei $n^{\circ} 10.520$, de 17 de julho de 2002. Institui, no âmbito da União, Estados, Distrito Federal e Municípios, nos termos do art. 37, inciso XXI, da Constituição Federal, modalidade de licitação denominada pregão, para aquisição de bens e serviços comuns, e dá outras providências. Diário Oficial [da] República Federativa do Brasil, Poder Legislativo, Brasília, DF, 17 jul. 2002.

BRASIL. Presidência da República. Casa Civil. Lei no 12.462, de 04 de agosto de 2011. Institui o Regime Diferenciado de Contratações Públicas - RDC. Diário Oficial 
[da] República Federativa do Brasil, Poder Legislativo, Brasília, DF, 04 ago. 2011.

BRASIL. Presidência da República. Casa Civil. Lei n 13.303, de 30 de junho de 2016. Dispõe sobre o estatuto jurídico da empresa pública, da sociedade de economia mista e de suas subsidiárias, no âmbito da União, dos Estados, do Distrito Federal e dos Municípios. Diário Oficial [da] República Federativa do Brasil, Poder Legislativo, Brasília, DF, 01 jul. 2016.

BRASIL. Presidência da República. Secretaria Geral. Decreto $n^{\circ}$ 9.377, de 17 de maio de 2018. Institui a Estratégia Nacional de Disseminação do Building Information Modelling. Diário Oficial [da] República Federativa do Brasil, Poder Legislativo, Brasília, DF, 18 mai. 2018b.

BRODEY, Ivan. Estação de Metrô Løren / Arne Henriksen Arkitekter + MDH Arkitekter. ArchDaily Brasil. 25 jul 2017. Disponível em: <https://www.archdaily.com.br/br/876425/estacao-de-metro-loren-arne-henriksenarkitekter-plus-mdh-arkitekter> ISSN 0719-8906. Acesso em: 17 mai. 2021.

BVY. Estação Penha de França. 2014. Disponível em: http://www.bvy.com.br/web/portfolio-items/estacao-penha-de-franca/. Acesso em: 25 jan. 2020.

BUJNOVSZKY, Tamás. Linha M4 do Metrô de Budapeste - Estação Kálvin tér / PALATIUM Studio. ArchDaily Brasil. 02 mar. 2015. Disponível em: <https://www.archdaily.com.br/br/762873/linha-m4-do-metro-de-budapeste-kalvin-terstation-palatium-studio> ISSN 0719-8906. Acesso em: 17 mai. 2021.

BUILDING SMART. IFC Infra Overall Architecture Project. 2017. Disponível em: https://www.buildingsmart.org/wp-

content/uploads/2017/07/08_bSI_OverallArchitecure_Guidelines_final.pdf. Acesso em: 7 jan. 2020.

CÂMARA BRASILEIRA DA INDÚSTRIA DA CONSTRUÇÃO - CBIC. A Produtividade da Construção Civil Brasileira (CE N²418/14 - Projeto 054/14). Belo Horizonte, 2014. Disponível em: http://www.cbicdados.com.br/media/anexos/070.pdf. Acesso em: 19 jul. 2018. 
COMPANHIA DO METROPOLITANO DE SÃO PAULO - CMSP. Projeto Padrão: PP-9-000000-6B3-900-H. São Paulo: CMSP, 1978.

COMPANHIA DO METROPOLITANO DE SÃO PAULO - CMSP. IP-9-000000/3A0001: Instrução de Projeto com diretrizes para elaboração da documentação técnica de engenharia civil, arquitetura, geotécnica, topografia, desapropriações e via permanente. São Paulo: CMSP, 2010.

COMPANHIA DO METROPOLITANO DE SÃO PAULO - CMSP. Projeto Funcional da Conexão da Linha 2-Verde com a Linha 3-Vermelha - Trecho Vila PrudenteDutra. São Paulo: CMSP, 2011a.

COMPANHIA DO METROPOLITANO DE SÃO PAULO - CMSP. IP-9-000000/3B3001: Instrução de projeto básico de arquitetura/acabamento e de comunicação visual. São Paulo: CMSP, $2011 b$.

COMPANHIA DO METROPOLITANO DE SÃO PAULO - CMSP. IC-9-000000/3B3002: Instrução complementar aos projetos básicos de arquitetura/acabamentos. São Paulo: CMSP, 2011c.

COMPANHIA DO METROPOLITANO DE SÃO PAULO - CMSP. IP-9-000000/3B2001: Instrução de projeto básico de arquitetura. São Paulo: CMSP, 2013a.

COMPANHIA DO METROPOLITANO DE SÃO PAULO - CMSP. IC-9-000000/3B3001: Instrução Complementar aos projetos básicos de acabamento e de comunicação visual. São Paulo: CMSP, 2013b.

COMPANHIA DO METROPOLITANO DE SÃO PAULO - CMSP. LM9.00.00.00/3B3-001: Lista geral de materiais de acabamento e de comunicação visual. São Paulo: CMSP, 2015.

COMPANHIA DO METROPOLITANO DE SÃO PAULO - CMSP. Concorrência internacional $n^{\circ}$ 41613213: Prestação de serviços técnicos especializados para elaboração do projeto básico de engenharia civil, do trecho Vila Prudente - Ipiranga do sistema monotrilho da linha 15 prata, da Companhia do Metropolitano de São Paulo - METRÔ. São Paulo: CMSP, 2014.

COMPANHIA DO METROPOLITANO DE SÃO PAULO - CMSP. Instrumento normativo: Elaboração e fornecimento da documentação técnica de engenharia 
civil, arquitetura, geotecnia, topografia, desapropriações e via permanente (MAN-10201). São Paulo: CMSP, 2016.

COMPANHIA DO METROPOLITANO DE SÃO PAULO - CMSP. METRÔ: 50 anos de realizações marcadas pelo pioneirismo, pela inovação e qualidade na prestação do serviço de transporte público. São Paulo: CMSP, 2018a. Disponível em: http://50anos.metrosp.com.br/. Acesso em: 4 nov. 2019.

COMPANHIA DO METROPOLITANO DE SÃO PAULO - CMSP. Relatório Integrado. São Paulo: CMSP, 2018b.

COMPANHIA DO METROPOLITANO DE SÃO PAULO - CMSP. Regulamento de Licitações, Contratos e demais ajustes. São Paulo: CMSP, 2019a.

COMPANHIA DO METROPOLITANO DE SÃO PAULO - CMSP. Relatório Integrado. São Paulo: CMSP, 2019b.

COMPANHIA DO METROPOLITANO DE SÃO PAULO - CMSP. Relatório de empreendimentos. São Paulo: CMSP, 2019c.

COMPANHIA DO METROPOLITANO DE SÃO PAULO - CMSP. Subterrâneo Tipos de construção. São Paulo: CMSP, 2019d. Disponível em: http://www.metro.sp.gov.br/tecnologia/construcao/subterraneo.aspx. Acesso em: 19 dez. 2019.

COMPANHIA DO METROPOLITANO DE SÃO PAULO - CMSP. Relatório de Empreendimentos - Jan/2021. São Paulo: CMSP, 2021. Disponível em: https://transparencia.metrosp.com.br/sites/default/files/RelPortaltrnsp_jan21_rev1.pdf . Acesso em: 20 mar. 2021.

CONSELHO NACIONAL DE JUSTIÇA - CNJ. Diagnóstico sobre obras paralisadas. CNJ, Brasília, 2019. Disponível em: https://www.cnj.jus.br/pesquisasjudiciarias/diagnostico-sobre-obras-paradas/. Acesso em: 6 fev. 2021.

CONTIER ARQUITETURA. Tutorial MCMV em BIM. São Paulo: 2011. Disponível em: http://contier.com.br/downloads. Acesso em: 15 set. 2018.

CONTROLADORIA-GERAL DA UNIÃO - CGU/ASCOM. Licitações e contratações. Portal da Transparência. 2019. Disponível em: 
http://www.portaltransparencia.gov.br/entenda-a-gestao-publica/licitacoes-econtratacoes. Acesso em: 15 out. 2019.

DANTAS, Rafael Balago Carolina. Governo de SP revê cronograma de todas as obras do metrô. Folha de São Paulo, São Paulo, 8 mar. 2015. Disponível em: https://www1.folha.uol.com.br/saopaulo/2015/03/1599259-governo-de-sp-revecronograma-de-todas-as-obras-do-metro.html. Acesso em: 2 dez. 2019.

EASTMAN, Chuck; TEICHOLZ, Paul; SACKS, Rafael; et al. Manual de BIM: um guia de modelagem da informação da construção para arquitetos, engenheiros, gerentes, construtores e incorporadores. Porto Alegre: Bookman, 2014.

EUBIM TASK GROUP. Manual relativo à aplicação da Modelação da Informação da Construção (BIM) no Setor Público Europeu: Ação estratégica para o desempenho do setor da construção. União Europeia: 2017. Disponível em: http://www.eubim.eu/handbook/. Acesso em: 10 jul. 2018.

ESTEVES, Ricardo Grisolia. Implantação BIM na FDE. In: INOVADAY. São Paulo: 2016. Disponível em: http://inovaday.com.br/br/bim-building-information-modeling. Acesso em: 5 jan. 2020.

FLORIO, Wilson. Modelagem Paramétrica no Processo de Projeto em Arquitetura. SBQP: Simpósio Brasileiro de Qualidade do Projeto no Ambiente Construído, $2009 . \quad$ Disponível em: https://www.iau.usp.br/ocs/index.php/SBQP2009/SBQP2009/paper/viewFile/98/115. Acesso em: 25 abr. 2020.

FIESP - FEDERAÇÃO DAS INDÚSTRIAS DO ESTADO DE SÃO PAULO. Relatório Corrupção: custos econômicos e propostas de combate. São Paulo: FIESP, 2010.

FIESP, Radar Brasil. Grandes obras: Linha 5-Lilás do metrô - Relatório Completo. São Paulo, 2021. Disponível em: http://radarbrasil.fiesp.com.br/linha-5-lilas-do-metrorelatorio-completo. Acesso em: 06 mar. 2021.

FOSTER AND PARTNERS. Bilbao Metro. Bilbao, Spain, 1995. Disponivel em: https://www.fosterandpartners.com/projects/bilbao-metro/\#drawings. Acesso em: 27 mar. 2021 
FUNDAÇÃO PARA O DESENVOLVIMENTO DA EDUCAÇÃO - FDE. Audiência Pública: Implantação BIM - Diretoria de Obras e Serviços. São Paulo: FDE, 2016a. Disponível em: http://arquivo.fde.sp.gov.br/fde.portal/PermanentFile/File/Audi\%C3\%AAncia_P\%C3\% BAblica_BIM_FDE_14_06_2016.pdf. Acesso em: 5 jan. 2020.

FUNDAÇÃO PARA O DESENVOLVIMENTO DA EDUCAÇÃO - FDE. Relatório do Grupo de Trabalho Relativo à Tecnologia BIM. São Paulo: FDE, 2016b. Disponível em: http://file.fde.sp.gov.br/portalfde/arquivo/Relat\%C3\%B3rio\%20Final\%20GTBIM\%20M AR\%C3\%870\%202017.pdf. Acesso em: 5 jan. 2020.

FUNDAÇÃO PARA O DESENVOLVIMENTO DA EDUCAÇÃO - FDE. Projeto Básico. São Paulo: FDE, 2016c. Disponível em: http://arquivo.fde.sp.gov.br/fde.portal/PermanentFile/File/Projeto_Basico_BIM_FDE\% 2025-05-16.pdf. Acesso em: 15 jan. 2020.

FUNDAÇÃO PARA O DESENVOLVIMENTO DA EDUCAÇÃO (FDE), Produtos técnicos. São Paulo: FDE, $2019 . \quad$ Disponível em: https://produtostecnicos.fde.sp.gov.br/Login.aspx. Acesso em: 5 jan. 2020.

FUNDAÇÃO PARA O DESENVOLVIMENTO DA EDUCAÇÃO - FDE. Produtos Técnicos. São Paulo: FDE, 2020. Disponível em: https://produtostecnicos.fde.sp.gov.br/Pages/CatalogosTecnicos/Default.aspx. Acesso em: 20 mar. 2021.

GABARRA, Murilo Macedo. Industrialização e padronização para expansão da rede de metrô de São Paulo. 2016. 138 f. Dissertação (Mestrado) - Curso de Arquitetura, FAUUSP, São Paulo, 2016.

GARCÉS, Jordi. 3 estações de metrô da Linha 9 de Barcelona / Jordi Garcés. 2014. ArchDaily Brasil. Disponível em: https://www.archdaily.com.br/br/625097/3estacoes-de-metro-da-linha-9-de-barcelona-jordi-garces. ISSN 0719-8906. Acesso em: 17 mai. 2021

HJORTSHOJ, Rasmus. Estações de Metrô Orientkaj e Nordhavn / Cobe + Arup. 23 nov. 2020. ArchDaily Brasil. Disponível em 
<https://www.archdaily.com.br/br/951720/estacoes-de-metro-orientkaj-e-nordhavncobe-plus-arup> ISSN 0719-8906. Acesso em: 17 mai. 2021.

INSTITUTO BRASILEIRO DE GEOGRAFIA E ESTATISTICA - IBGE. Pesquisa Anual da Indústria da Construção - PAIC. Diretoria de Pesquisas, Coordenação de Serviços e Comércio. IBGE, 2016. 4 p.

JOHNSTON, Jaimie. Platforms: Bridging the gap between construction and manufacturing. In: NBS (org.). National BIM Report 2018. Newcastle: Riba Enterprises, 2018. p. 4-9. Disponível em: http://www.bimacademy.global/wpcontent/uploads/2018/05/NBS0850-BIM-Report-2018-LR-.pdf. Acesso em: 03 set. 2018.

KASSEM, Mohamad; AMORIM, Sergio R. Leusin de. BIM - Building Information Modeling no Brasil e na União Europeia. Brasília: Diálogos Setoriais, 2015. 159 p. KLINCEVICIUS, Mary Gisele Yoshimori. Estudo de propriedades, de tensões e do comportamento mecânico de lastros ferroviários. 2011. Dissertação (Mestrado em Engenharia de Transportes) - Escola Politécnica, Universidade de São Paulo, São Paulo, 2011. Disponível em: https://teses.usp.br/teses/disponiveis/3/3138/tde27032012-121114/en.php. Acesso em: 03 set. 2018.

KON, Nelson. Estação Vila Prudente / Luiz Esteves Arquitetura. ArchDaily Brasil. 26 jul. 2016. Disponível em: <https://www.archdaily.com.br/br/792048/estacao-vilaprudente-luiz-esteves-arquitetura> ISSN 0719-8906. Acesso em: 17 mai. 2021.

LACERDA, Daniel Pacheco et al. Design Science Research: método de pesquisa para a engenharia de produção. Gestão \& Produção, São Carlos, v. 20, n. 4, p.741761, ago. 2013.

LIPSON, H.; KURMAN, M. Fabricated: the new world of 3d printing. Indianapolis: Wiley, 2013.

MCPARTLAND, Richard. What is the PAS 1192 framework?. NBS, Newcastle, 17 set. 2017. Disponível em: https://www.thenbs.com/knowledge/what-is-the-pas-1192framework. Acesso em: 26 mai. 2020. 
MALONA. U-Bahn am Marienplatz. München, 2007. Disponível em: https://www.flickr.com/photos/malona/395304728/in/photostream/. Acesso em: 16 mai. 2021.

MAINARDI, Ivo; SACCOMANO, Daniel Mozarte. BIM aplicado ao Metrô: porque o metrô investe neste novo processo. In: SEMANA DE TECNOLOGIA METROFERROVIÁRIA, 19., 2013, São Paulo. Anais... . São Paulo: AEAMESP, 2013. p. 1 - 9.

MAINARDI, Antonio Ivo de Barros. O BIM chegou à primeira estação: Ponte Grande. São Paulo: AEAMESP, 2015a. 34 slides, color.

MAINARDI, Antonio Ivo de Barros. et al. O BIM chegou à primeira estação: Ponte Grande. In: SEMANA DE TECNOLOGIA METROFERROVIÁRIA, 22., 2015, São Paulo. Anais [...]. São Paulo: AEAMESP, 2015b. p. 1-22.

MAINARDI, Antonio Ivo de Barros; SOUZA, Benedito Tadeu de; TAQUEDA, João Carlos Santos. et al. Processo de desenvolvimento de objetos BIM de elementos padronizados de arquitetura do Metrô-SP. In: 24a SEMANA DE TECNOLOGIA METROFERROVIÁRIA. 32., 2018. São Paulo: AEAMESP, 2018, p. 1-32. Disponível em: http://www.aeamesp.org.br/wp-content/uploads/2019/05/t57.pdf. Acesso em: 22 dez. 2019.

MANZIONE, Leonardo. Proposição de uma estrutura conceitual de gestão do processo de projeto colaborativo com uso do BIM. 2013. Tese (Doutorado em Engenharia de Construção Civil) - Escola Politécnica, Universidade de São Paulo, São Paulo, 2013.

METROCPTM. Corte da estação Água Rasa. 2020. Disponível em: https://www.metrocptm.com.br/veja-como-serao-as-novas-estacoes-da-linha-2verde-ate-penha/agua-rasa3/. Acesso em: 25 jan. 2020.

MINEIRO, E. F.; MAGALHÃES, C. F. Design paramétrico e generativo: modos de explorar a complexidade. Gestão e Tecnologia de Projetos, São Carlos, v.14, n. 2, p.6-16, 2019. http://dx.doi. org/10.11606/gtp.v14i2.151419.

NATIONAL BUILDING SPECIFICATION - NBS. National BIM Library. Riba $\begin{array}{llllll}\text { Enterprises, } & \text { NBS, } & 2019 . & \text { p. } & \text { Disponível }\end{array}$ 
https://www.nationalbimlibrary.com/en/nbs-bim-object-standard. Acesso em: 15 jul. 2019

NATIONAL BUILDING SPECIFICATION - NBS. National BIM Report 2018. Riba Enterprises, NBS, 2018. 27 p. Disponível em: www.bimacademy.global/wpcontent/uploads/2018/05/NBS0850-BIM-Report-2018-LR-.pdf. Acesso em: 03 set. 2018.

NATIONAL INSTITUTE OF BUILDING SCIENCES - NIBS. National BIM StandardUnited States. United States: NIBS, 2015. Disponível em: https://www.nationalbimstandard.org/files/NBIMS-US_FactSheet_2015.pdf. Acesso em: 13 jul. 2017.

NETO, Francisco Ribeiro. et al. Aspectos Construtivos da Estação Chácara Klabin da Expansão da Linha 2 - Verde do Metrô de São Paulo. São Paulo: Núcleo Engenharia e Projetos, 2006, 8p. Disponível em: http://nucleoprojetos.com.br/wp-content/uploads/2017/11/Trab-KlabinCobramseg2006.pdf. Acesso em: 28 jan. 2020.

NETWORK RAIL. Station Design Strategy for Network Rail. Network Rail, London, 2015. Disponível em: https://cdn.networkrail.co.uk/wpcontent/uploads/2019/03/Station-design-principles.pdf. Acesso em: 15 nov. 2019.

NETWORK RAIL. IP Building Information Modelling (BIM) Strategy: 159074 BIM4IP Programme. Network Rail, London, 2020. Disponível em: https://nrbimportal.co.uk/storage/19/159074-BIM4IP-IP-BIM-Strategy-v1.0.pdf. Acesso em: 29 jun. 2020.

NUNES, Henrique Martins. Sistemas de Classificação de Informação da Construção - Proposta de metodologia orientada para objetos BIM. 2016. Dissertação (Mestrado em Engenharia Civil - Perfil Construção), Faculdade de Ciências e Tecnologia, Universidade Nova de Lisboa, Lisboa, 2016. Disponível em: http://hdl.handle.net/10362/20165. Acesso em: 25 abr. 2020.

OAKLEY, Tiago Carvalho. Arquitetura das estações de conexão na rede de metrô de São Paulo. 2017. Dissertação (Mestrado em Projeto de Arquitetura) Faculdade de Arquitetura e Urbanismo, Universidade de São Paulo, São Paulo, 2014. DOI: 10.11606/D.16.2018.tde-22062017-162656. Acesso em: 17 out. 2019. 
OLIVEIRA, Otávio J.; MELHADO, Silvio Burrattino. Como Administrar Empresas de Projeto de Arquitetura e Engenharia Civil. São Paulo: Pini, 2006.

POLJANŠEK, Martin. JRC Technical Reports: Building Information Modelling (BIM) standardization. Ispra: European Commission, 2017. ISBN: 978-92-79-77206-1. ISSN: 1831-9424. DOI: 10.2760/36471. Disponível em: https://publications.jrc.ec.europa.eu/repository/bitstream/JRC109656/jrc109656_bim. standardization.pdf. Acesso em: 6 maio 2020.

PORTUGAL, Marco Antonio. Corrupção em obras públicas: Uma análise dos procedimentos licitatórios no papel de combate à corrupção. 2017. 236 f. Dissertação (Mestrado) - Curso de Administração, Centro Universitário FEI, São Paulo, 2017.

RASMUSSEN, Ana Flora Machado. Gestão de Obras Públicas: um diagnóstico sobre aditivos de contratos. Dissertação (Mestrado em Arquitetura, Urbanismo e Tecnologia) - Escola de Engenharia de São Carlos, Universidade de São Paulo, São Carlos, 2013. DOI:10.11606/D.18.2013.tde-09052014-155230. Acesso em: 15 nov. 2019.

SANTOS, Marcelo Augusto Marques dos. A distribuição da demanda de viagens no metrô e sua aplicação no dimensionamento da oferta de trens". In: $11^{\circ}$ CONGRESSO DE TRANSPORTE E TRÂNSITO. 11., 1997, Belo Horizonte, 1997. Anais [...]. Belo Horizonte: ANTP, 1997. Disponível em: http://filesserver.antp.org.br/_5dotSystem/download/dcmDocument/2013/01/21/BA29C597B014-4DF3-A0B6-4DEE55ED2249.pdf. Acesso em: 18 dez. 2018.

SANTOS, H.P. Diagnóstico e análise das Causas de Aditivos Contratuais de Prazo e Valor em Obras de Edificações em Uma Instituição Pública. 2015. Dissertação (Mestrado em Construção Civil) - Escola de Engenharia, Universidade Federal de Minas Gerais, 2015.

SECRETARIA DOS TRANSPORTES METROPOLITANOS. Concorrência Internacional № 01/2017, Processo STM № 816/2017, Concessão Linha 15 Prata. São Paulo: STM, 2017.

SECRETARIA DE ESTADO DE INFRAESTRUTURA E LOGÍSTICA. Implementação BIM no Paraná. Paraná: SEIL, 2019. Disponível em: 
http://www.bim.pr.gov.br/Pagina/Implementacao-BIM-no-Parana\#. Acesso em: 27 ago. 2019.

SLUNECKO, Ondrej. What is Algorithms-Aided Design. Constructing Architect. Denmark, 2020. Disponível em: https://www.constructingarchitect.com/what-isalgorithms-aided-design/. Acesso em: 14 mar. 2021.

SUCCAR, Bilal. 211 in Model Uses Table (version 1.26). BIMe Initiative. Melbourne: Change Agents AEC, 2019.

SUCCAR, B.; SALEEB, N.; SHER, W. Model Uses: Foundations for a Modular Requirements Clarification Language. In: AUSTRALASIAN UNIVERSITIES BUILDING EDUCATION (AUBEA2016), 13., 2016. Proceedings [...]. Cairns, Australia: AUBEA, 2016.

THE ECONOMIST. Efficiency eludes the construction industry - Least-improved. 2017. The Economist, Berlin, London e Malmo, 17 ago. 2017. Disponível em: https://www.economist.com/business/2017/08/17/efficiency-eludes-the-constructionindustry. Acesso em: 22 set. 2018.

TRANSPARÊNCIA INTERNACIONAL (Org.). Índice de percepção da corrupção 2018-2019. Transparência Internacional - Brasil, 2019. Disponível em: https://ipc2018.transparenciainternacional.org.br/\#brasil Acesso em: 15 nov. 2019.

TUPINAMBÁ Nestor Soares. Diretrizes técnicas para o projeto de uma linha de metrô, no Metrô-SP - Análise de um caso real. 2007. Dissertação (Mestrado em Planejamento Urbano e Regional) - Faculdade de Arquitetura e Urbanismo, Universidade de São Paulo, São Paulo, 2007. DOI:10.11606/D.16.2007.tde28052010-152006. Acesso em: 17 out. 2019.

UNDERWOOD, Jason; ISIKDAG, Umit. Preface: being lost or becoming lost. In: UNDERWOOD, Jason; ISIKDAG, Umit. Handbook of Research on Building Information Modeling and Construction Informatics: Concepts and Technologies. IGI Global, 2010. DOI: 10.4018/978-1-60566-928-1. Acesso em: 6 maio 2020.

WORLD ECONOMIC FORUM - WEF. An Action Plan to Accelerate Building Information Modeling (BIM) Adoption. Geneva: World Economic Forum, 2018. Disponível em: 
http://www3.weforum.org/docs/WEF_Accelerating_BIM_Adoption_Action_Plan.pdf. Acesso em: 18 ago. 2018.

WORLD ECONOMIC FORUM - WEF. Shaping the Future of Construction: A Breakthrough in Mindset and Technology. Geneva: World Economic Forum, 2016. Disponível em: http://www3.weforum.org/docs/WEF_Shaping_the_Future_of_Construction_full_repo rt__.pdf. Acesso em: 7 maio 2020. 